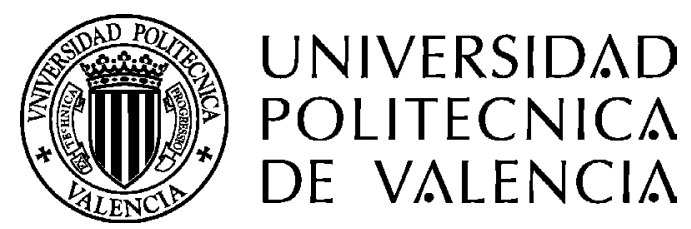

Departamento de Biotecnología

\title{
Análisis funcional y aplicaciones biotecnológicas del promotor del gen END1 de guisante (Pisum sativum L.)
}

\author{
Memoria presentada por \\ EDELÍN MARTA ROQUE MESA \\ para optar al grado de \\ DOCTOR por la \\ Universidad Politécnica de Valencia
}

Directores

Dr. Francisco Madueño Albi

Dr. Luis Cañas Clemente

Dr. José Pío Beltrán Porter 



\section{AGRADECIMIENTOS}

Si ha sido una tarea ardua entregar esta memoria, será igual de difícil plasmar en un espacio tan reducido mi más sincero agradecimiento a todas las personas que me han acompañado en este largo camino.

En primer lugar me gustaría darle las gracias a mis directores de Tesis: A Paco Madueño, porque detrás de cada experimento y cada frase está su sabiduría y su dedicación. Hemos compartido muchas horas de planificación de experimentos, análisis de resultados y corrección de las páginas de esta tesis. Sin su guía a los largo de estos años, nada hubiese sido posible. Gracias de corazón, Paco. A Luis Cañas, por el optimismo puesto en cada resultado y por su habilidad y destreza con las cámaras e imágenes que han hecho de mis flores y anteras auténticas "Top Models”. Muchas gracias Luis !. A José Pío, por aceptarme a trabajar en su laboratorio y confiar en mí. Desde que llegué le he dado seguro más "faena" que "recompensa" pero nunca ha dejado de ayudarme. Por esto, y por la certera dirección de este trabajo, mil gracias José Pío!.

Muchas Gracias a Philippe, por dividirse en un pedazo más y trabajar en nuestro proyecto. Los resultados obtenidos en tomate han sido posible gracias a sus manos expertas en transformación. Ha sido un placer trabajar con una persona tan eficiente con la que he aprendido que siempre se puede hacer más.

Agradezco a todos mis compañeros del laboratorio su cariño a lo largo de todos estos años: A la antecesora de este trabajo, María Dolores (MD), tengo que agradecerle todo lo que me ha enseñado. No sólo me ha ayudado a aprender el manejo de microtomos y microscopios, sino que me ha hecho partícipe de sus conocimientos. Gracias, también por tu amistad. A Ana, por ser ejemplo de trabajadora tenaz e incansable. Quiero agradecer su amistad y el cariño que siempre me ha mostrado. A Tere, que me ha querido siempre desde que llegué, pendiente de cada problema y en disposición permanente de ayudarme. A Cristina Navarro (la Kristin Klander), de quien es imposible olvidarnos. Ha dejado un recuerdo imborrable en este laboratorio. A Majo, porque es la "Reina del cultivo y cuidado de las Arabidopsis" y siempre está dispuesta cuando la necesito. A Alicia y Roberto, mis dos compañeros de poyata en estos años, gracias por ayudarme con vuestros consejos en cada momento. A Reyes, Antoñico, Noelia, Cristina Ferrándiz, por escuchar mis dudas y haber dedicado parte de su tiempo en ayudarme a resolverlas. A Amparo, por su desenvolvimiento en la organización de las actividades "lúdico-festivas" que tan importante son para la vida del laboratorio. A Mari Cruz, por ser la técnico de laboratorio más eficiente, trabajadora y simpática que nos haya podido tocar. A Begoña y Joanna, por llenar de alegría cada uno de los días. A todos los demás chicos/as que también forman parte de este laboratorio: Marina, Vicente, Carol, Laura, Begoña (mini), gracias por compartir 
conmigo la vida en esta gran casa. No puedo olvidarme de todos los compañeros que ya no están pero que han engrosado las listas de nombres de nuestro laboratorio: Mati, Rosa, Mónica, Juanma, Laura, Teresiña. A todos ellos, muchas gracias por compartir conmigo tantos días de mi vida.

A María Ángeles, quiero agradecerle el cariño con el que siempre me ha tratado. Siempre pendiente de mí, siempre involucrada en mis problemas de aquí y de "alli". Gracias, María Ángeles. A Ana Ahuir y Cristina Urbez, muchas gracias por vuestro apoyo y cariño. A todos los compañeros maravillosos de este Instituto, especialmente a los de los laboratorios de la segunda planta, muchas gracias por los buenos momentos que hemos compartido.

Quiero darle las gracias a José Luis García Martínez, Antonio Granell y Vicente Moreno por responder siempre con amabilidad mis múltiples dudas. Agradecer a Assumpta, la búsqueda de la mayoría de la bibliografía citada en este trabajo y su eterna sonrisa. A Eugenio, por ser tan simpático y secuenciar una y otra vez mis muestras, que por razones desconocidas para él y para mí, nunca estaban bien a la primera. Al personal del invernadero que cuida nuestras plantas. A Alexis y Ramón, por mantener en funcionamiento los ordenadores, equipos indispensables en estos "abatares" científicos. A Santiago y Jose el mantenimiento y cuidado de todos los aparatos con los que día a día hacemos nuestro trabajo. A Ana Mira, que ha sido casi parte de nuestro laboratorio, por tratar con esmero nuestros medios de cultivo y soluciones, y luego, por ser la secretaria de personal más eficiente. De manera general, a todo el personal del IBMCP (administración y servicios) porque de una manera u otra han sido imprescindibles para llevar a cabo este trabajo.

Quiero darle las gracias a Vicente Conejero porque, desde que me vio por primera vez en el Instituto de Genética y Biotecnología de La Habana, no ha dejado de ayudarme. Gracias a él he tenido financiado gran parte del período de tesis.

Quiero agradecer a mis amigos cubanos por compartir conmigo como parte de una gran familia. Gracias por estar ahí.

Ahora, un punto y aparte para agradecer a mi madre y a Armand todo el apoyo que desde la distancia me han brindado. La realización de este trabajo ha sido para ellos el aliciente que les ha ayudado a vivir sin mí. A mi madre, gracias además por venir a cuidar de mi bebé en estos últimos tiempos, los más estresantes y agotadores que lo hubiesen sido el doble sin su ayuda. Gracias mami, por todo lo que haces por mí. A toda mi familia: mi abuela Edilia, mis primos Gloria, Jorge y Caty, mi media abuela Cristina, mi hermano Romi y mi cuñada Lissette, gracias por ser la mejor familia. A Amparo, mi madre española, gracias por todo lo que me ayudas y por quererme como a otra hija. Gracias Vicente, Clara y Marco por tenernos como parte de su familia. 
A Goar, mi peluche, no tengo palabras con las que agradecer todo su amor. Este amor se traduce en ánimos, optimismo y ayuda incondicional en mi trabajo: sembrar plantas, hacer cruces, contar silicuas y arreglar figuras incontrolables. En esta tesis se ha involucrado tanto como yo. Sin él, no hubiese tenido la felicidad que se necesita en la vida para emprender cualquier tarea.

En el momento en que empecé a escribir este trabajo, ya se estaba formando en mi interior una nueva vida. Mi Sarita ha ido creciendo con las páginas de esta tesis. Gracias mi gordi por tu risa que es el motor impulsor de mi vida.

A mi abuelo Rolando, le agradezco sus enseñanzas en materia de ciencias. Te hubiese hecho muy feliz ver tu nombre en la dedicatoria de esta memoria. Donde estés, esto es para ti.

Este trabajo ha sido financiado por el Ministerio de Ciencia y Tecnología mediante los proyectos BIO2000-0940 y BIO2003-01171. Ha sido posible la realización del mismo gracias a la beca otorgada por las Cortes Valencianas en su programa de ayuda a los países del tercer mundo, a las becas de acción social otorgadas por el Rector de la Universidad Politécnica de Valencia Justo Nieto Nieto y a los contratos de trabajo adjudicados a los proyectos antes mencionados. 

A mi abuelo Rolando 



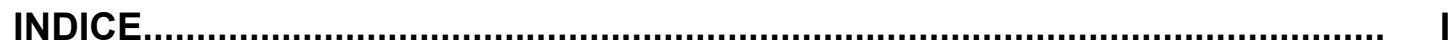

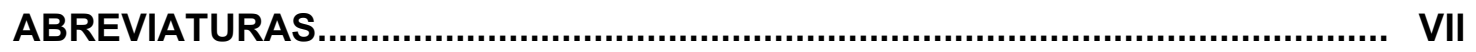

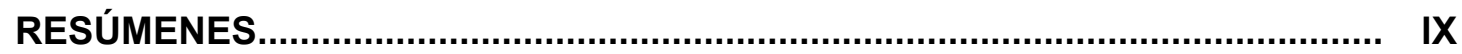

I. INTRODUCCIÓN.........................................................................................

1. Desarrollo reproductivo en angiospermas. Función reproductora de la flor...... 3

1.1. Ontogenia, estructura y función de la flor............................................. 3

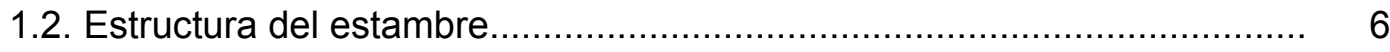

1.3. Desarrollo de la antera..................................................................... 6

1.4. Polinización y fertilización................................................................. 11

2. Control genético de la identidad de los órganos florales.............................. 13

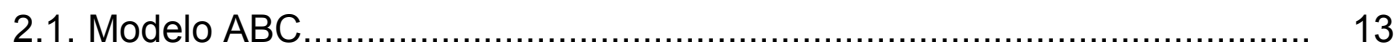

2.2. Genes que controlan la identidad del estambre ................................... 16

2.3. Genes diana de las proteínas MADS-box implicados en la diferenciación del estambre............................................................... 18

2.4. Genes de expresión específica en estambre......................................... 20

2.5. Análisis de promotores de genes específicos de antera......................... 23

3. Plantas androestériles: uso en la agricultura............................................. 26

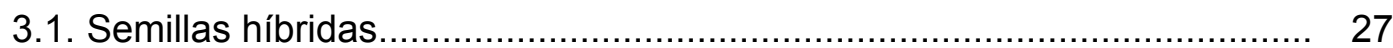

3.1.1. Métodos para la obtención de semillas híbridas......................... 27

3.2. Androesterilidad nuclear por ingeniería genética.................................... 29

3.2.1. Métodos moleculares usados para la obtención de plantas androestériles.

3.2.2. Inducción de androesterilidad nuclear mediante la expresión de un gen citotóxico................................................. 31

3.2.2.1. Ablación celular............................................................. 31

3.2.2.2. Genes citotóxicos....................................................... 32

3.2.2.3. Barnasa y barstar................................................... 32

3.2.2.4. Uso del sistema barnasa-barstar para la obtención de semillas híbridas.......................................... 33

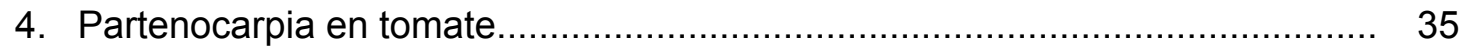

4.1. Relación entre los genes homeóticos florales y la partenocarpia en

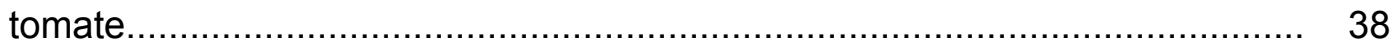

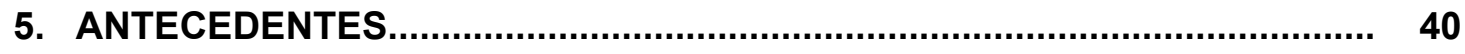

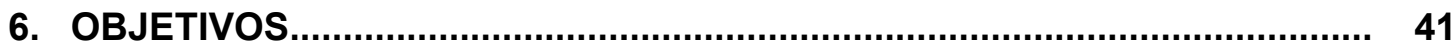


II. MATERIALES Y MÉTODOS................................................................ 43

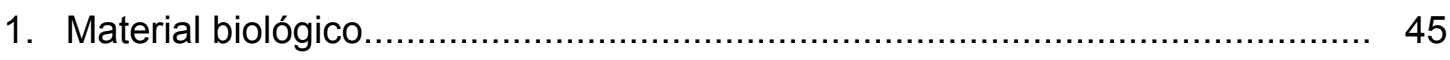

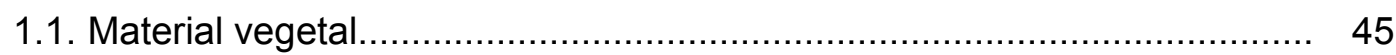

1.1.1. Condiciones de cultivo de las plantas...................................... 45

1.1.1.1. Cultivo de Arabidopsis thaliana en alvéolos y macetas...... 45

1.1.1.2. Cultivo de Arabidopsis thaliana en cajas Petri.................. 46

1.1.1.3. Cultivo de Nicotiana tabacum en macetas....................... 46

1.1.1.4. Cultivo de Nicotiana tabacum en cajas de Petri................. 47

1.1.1.5. Cultivo de Lycopersicon esculentum en frascos de

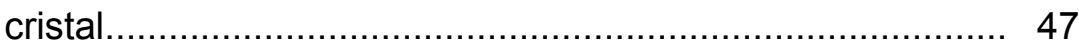

1.1.1.6. Cultivo de Lycopersicon esculentum en macetas.............. 48

1.1.2. Polinización cruzada........................................................... 48

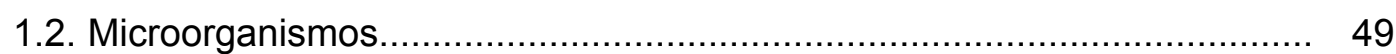

1.2.1. Cepas bacterianas................................................................. 49

1.2.2. Condiciones de cultivo de microorganismos............................... 49

1.2.3. Medio de cultivo de microorganismos......................................... 49

2. Preparación de muestras vegetales para microscopía óptica y microscopía electrónica de barrido (SEM) .............................................. 49

2.1. Fijación...................................................................................... 49

2.2. Inclusión en parafina.............................................................. 50

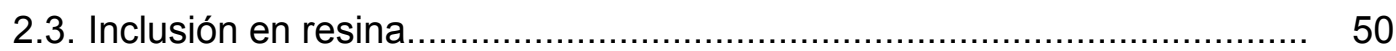

2.4. Procesamiento de las muestras incluidas en parafina o resina............... 50

2.5. Punto crítico y análisis de las muestras............................................... 51

3. Manipulación de ácidos nucléicos.............................................................. 51

3.1. Clonación...................................................................................... 51

3.2. Reacciones enzimáticas........................................................... 52

3.2.1. Reacciones de ligación......................................................... 52

3.2.2. Digestión con enzimas de restricción....................................... 52

3.2.3. Defosforilación de extremos cohesivos (5' protuberantes)............ 52

3.3. Amplificación de DNA por reacción en cadena de la polimerasa

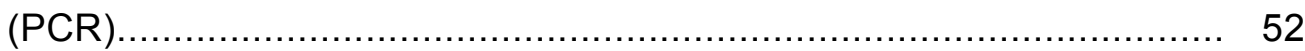

3.4. Purificación de fragmentos de DNA a partir de geles de agarosa............ 53

3.5. Secuenciación.................................................................... 53

4. Aislamiento y purificación de ácidos nucléicos............................................ 54

4.1. Aislamiento de DNA plasmídico.................................................. 54

4.1.1. Aislamiento de DNA plasmídico en Escherichia coli.................... 54 
4.1.2. Aislamiento de DNA plasmídico de Agrobacterium tumefaciens.... 54

5. Extracción de DNA genómico de tomate................................................ 55

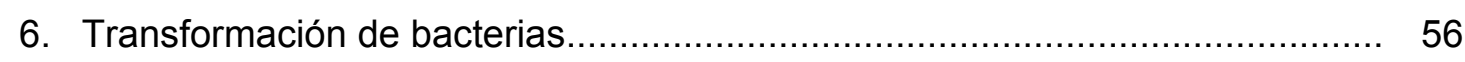

6.1. Preparación de células competentes y métodos de transformación......... 56

6.1.1. Transformación por electroporación.......................................... 56

6.1.2. Selección de recombinantes bacterianos.................................... 56

7. Transformación de plantas.................................................................. 57

7.1. Diseño de las construcciones para la transformación de plantas............ 57

7.1.1. Diseño de la construcción pBI-END1:: barnasa-barstar................ 57

7.1.2. Diseño de la construcción pBI-END1- barstar............................. 57

7.1.3. Diseño de las construcciones utilizadas para el análisis funcional del promotor de END1 .......................................... 59

7.1.3.1. Diseño de las construcciones con deleciones de la región promotora de END1 ..................................... 59

7.1.3.2. Diseño de las construcciones con fragmentos de la región promotora de END1 con deleciones internas de posibles elementos reguladores.

7.2. Transformación de Arabidopsis thaliana y análisis de las plantas transgénicas.

7.2.1. Búsqueda de plantas transgénicas homocigotas para

END1:: barstar.

7.3. Transformación de Nicotiana tabacum y análisis fenotípico de las plantas transformadas.

7.4. Transformación de Lycopersicon esculentum (cv. Micro-Tom) y análisis de las plantas transgénicas.

7.4.1. Evaluación del nivel de ploidía en la generación $T_{1}$ de plantas END1::barnasa de tomate (cv. Micro-Tom)

8. Análisis de la germinación y viabilidad de los granos de polen de plantas

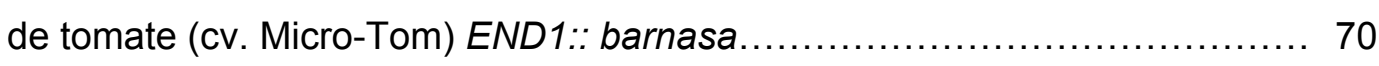

8.1. Ensayo de germinación del polen in vitro........................................ 70

8.2. Análisis de la viabilidad de los granos de polen................................ 71

III. RESULTADOS.

1. Obtención de plantas transgénicas androestériles de Arabidopsis thaliana y Nicotiana tabacum por ingeniería genética utilizando el promotor del gen END1 de guisante................................................... 79

1.1. Androesterilidad en Arabidopsis thaliana.......................................... 79 
1.1.1. Transformación de plantas de Arabidopsis thaliana con la construcción $\mathrm{pBI}-$ END1:: barnasa-barstar.

1.1.2. Análisis por microscopía de anteras END1::barnasa de Arabidopsis thaliana.

1.1.3. Estudio comparativo del desarrollo de anteras silvestres y END1:: barnasa de Arabidopsis.

1.1.4. Análisis de la segregación del transgén y de la germinación de las semillas de las líneas END1:: barnasa. 86

1.1.5. Eficiencia del transgén END1::barnasa en la obtención de androesterilidad.

1.1.6. Restauración de la fertilidad en plantas de Arabidopsis END1:: barnasa.

1.2. Androesterilidad en Nicotiana tabacum.

1.2.1. Transformación de plantas de Nicotiana tabacum con la construcción pBI-END1:: barnasa-barstar

1.2.2. Análisis por microscopía de anteras END1:: barnasa de Nicotiana tabacum.

2. Obtención de plantas transgénicas androestériles y desarrollo partenocárpico del fruto en Lycopersicon esculentum. 100

2.1. Transformación de Lycopersicon esculentum (cv. Micro-Tom) con la construcción pBI-END1::barnasa-barstar.. 100

2.2. Estudio comparativo del desarrollo de anteras silvestres de tomate (cv. Micro-Tom) anteras END1:: barnasa con fenotipo severo. 103

2.3. Desarrollo partenocárpico de los frutos en las plantas de tomate END1::barnasa.... 106

2.4. Análisis de la viabilidad y germinación del polen en anteras END1::barnasa de fenotipo medio y leve. 108

3. Análisis funcional del promotor del gen END1 de guisante. 111

3.1. Breve descripción de la secuencia promotora de END1. 111

3.2. Análisis de la expresión de GUS en plantas de Arabidopsis transformadas con construcciones con deleciones de la región promotora de END1 
3.3. Análisis de la expresión de GUS en plantas de Arabidopsis transformadas con construcciones que contienen fragmentos de la región promotora de END1 con deleciones internas.

IV. DISCUSIÓN.

1. Expresión del transgén END1::barnasa en plantas transgénicas 122

1.1. Androesterilidad en plantas transgénicas.

1.2. Eficiencia del promotor de END1 para la producción de plantas androestériles 126

1.3. Restauración de la fertilidad en plantas estériles END1::barnasa. 126

1.4. Efectividad del promotor END1 de guisante en otras especies. 128

1.5. Desarrollo partenocárpico de frutos en plantas END1::barnasa de tomate (cv. Micro-Tom). 128

2. Análisis funcional del promotor de END1 132

V. CONCLUSIONES 141

VI. BIBLIOGRAFÍA. 



\section{ABREVIATURAS}

$\begin{array}{ll}\text { 6-BAP } & \text { 6- bencil aminopurina } \\ \text { CaMv35S } & \text { promotor 35S del virus del mosaico de la coliflor } \\ \text { cDNA } & \text { DNA complementario } \\ \text { CTAB } & \text { N- Cetil-N, N,N-Trimetilamonio Bromuro } \\ \text { cV. } & \text { cultivar } \\ \text { DNA } & \text { ácido desoxirribonucléico } \\ \text { DTT } & \text { ditiotreitol } \\ \text { EDTA } & \text { etilen-diamino-tetraacetato sódico } \\ \text { EMS } & \text { etil-metanosulfonato } \\ \text { h } & \text { horas } \\ \text { IAA } & \text { ácido indol-3- acético } \\ \text { IPTG } & \text { isopropil- } \beta \text {-D-tiogalactósido. } \\ \text { kb } & \text { kilobases } \\ \text { M } & \text { molar } \\ \text { MES } & \text { ácido 4 morfolino-etano-sulfónico } \\ \text { min } & \text { minutos } \\ \text { MS } & \text { medio de Murashige y Skoog (incluyendo vitaminas) } \\ \text { pb } & \text { pares de bases } \\ \text { PVP } & \text { polivinilpirrolidona } \\ \text { RNA } & \text { ácido ribonucléico } \\ \text { rpm } & \text { revoluciones por minuto } \\ \text { RT-PCR } & \text { retrotranscripción seguida de PCR } \\ \mathrm{S} & \text { segundos } \\ \text { TBE } & 90 \text { mM (1X) Tris, } 90 \text { mM ácido bórico, 2mM EDTA } \\ \text { TESPA } & 3 \text { - amino-propil-trietoxisilano } \\ \text { Tris } & \text { X-Gal } \\ \text { X-Glc A } & \end{array}$



RESÚMENES 



\section{Resumen}

END1 es un gen de guisante (Pisum sativum L.) específico de antera que comienza a expresarse desde estadios tempranos del desarrollo (primordio de antera) en aquellas líneas celulares que darán lugar a los tejidos epidermis, conectivo, capa intermedia y endotecio, y en estos tejidos una vez desarrollados. La región promotora de dicho gen es capaz de dirigir la expresión específica del gen uidA (GUS) a las anteras de plantas de diferentes especies (Arabidopsis thaliana, Nicotiana tabacum y Lycopersicon esculentum). El patrón de expresión del gen GUS en esas plantas es similar al del gen END1 en guisante. Esta especificidad que confiere el promotor de END1 para la expresión de un gen foráneo en las anteras ofrecía la posibilidad de utilizarlo, fusionándolo a un gen citotóxico, como una herramienta biotecnológica para la obtención de plantas transgénicas androestériles.

En este trabajo, hemos fusionado la región 5' completa (-2736/-6) del promotor de END1 a la secuencia codificante de la ribonucleasa extracelular producida por el Bacillus amyloliquefaciens, barnasa. Con esta construcción hemos transformado dos plantas modelo, Arabidopsis y tabaco y una planta de interés agronómico, el tomate. La expresión del gen citotóxico barnasa donde END1 es activo, trajo como consecuencia una degeneración de tejidos de la antera que inhibió el desarrollo de los granos de polen. Las plantas transgénicas resultantes fueron androestériles. Los estudios a nivel histológico de las anteras transgénicas mostraron que los efectos de la barnasa comienzan a observarse muy pronto en el primordio de antera, cuando este está constituido sólo por células indiferenciadas, y continúa observándose a lo largo del desarrollo de la misma. De manera general, al final del programa de desarrollo, las anteras transgénicas eran de menor tamaño, su morfología era distinta de las de las anteras silvestres correspondientes, y en su interior se observaba el tejido conectivo colapsado y una estructura amorfa en lugar de granos de polen viable. La posible pérdida de las células parietales primarias por la acción ribonucleasa podría estar afectando la diferenciación de las células esporógenas, contiguas en el territorio del futuro microsporangio. Estos resultados muestran que el promotor de END1 podría ser una herramienta biotecnológica útil en los programas de obtención de semillas híbridas de diferentes cultivos de interés agronómico.

En el caso particular del tomate, todas las plantas transgénicas androestériles produjeron frutos partenocárpicos. Este resultado muestra que existe una relación entre la androesterilidad y el desarrollo autónomo del ovario en esa especie.

Por otra parte, se ha realizado un análisis del promotor del gen END1. Para este análisis se realizaron delecciones sucesivas de la región 5' del gen y los fragmentos resultantes se fusionaron transcripcionalmente al gen delator uidA (GUS). Con estas construcciones se 
transformaron plantas de $A$. thaliana y se estudió la expresión del gen uidA mediante el ensayo histoquímico de la actividad de la $\beta$-glucuronidasa. Hemos visto que el fragmento de 366/-6 de la región 5' es la secuencia mínima con capacidad para dirigir la correcta expresión espacial y temporal del gen END1. La pérdida de la expresión de GUS en las anteras de las plantas de Arabidopsis thaliana transformadas con el fragmento de la región 5' donde se elimina el motivo CArG2, apoya la hipótesis de que END1 podría estar regulado directamente por los genes de identidad de órgano de clase $\mathrm{B}$ y $\mathrm{C}$. 


\begin{abstract}
END1 is an anther-specific gene of pea (Pisum sativum. L) that displays specific expression in the cell lines that will develop the epidermis, connective, middlle layer and endothecium tissues from very early stages (anther primordium) to late stages of the anther development. The END1 promoter region drives the uidA (GUS) gene expression specifically to the anthers of Arabidopsis thaliana, Nicotiana tabacum and Lycopersicon esculentum. The chimaeric END1::GUS gene is regulated exactly like the endogenous END1. The spatial and temporal expression pattern of END1 and the functionality of its promoter region in different plant species suggested us the possibility to use its promoter region for biotechnological applications.

We fused the 2'7 kb END1 5' region with the ribonuclease barnase gene. The barnase is a natural ribonuclease isolated from Bacillus amyloliquefaciens. The chimaeric END1::barnasa gene was introduced into Arabidopsis, tobacco and tomato plants. The expression of the chimaeric gene inhibited anther morphogenesis and efficiently produced male-sterile transgenic plants. A detailed histological study of the development of both, WT and transgenic anthers, showed severe morphological differences from very early stages of anther development. The effects of barnase in transgenic anthers appeared when the anther was at the stage of anther primordium and it was composed by undifferentiated cells. Our results show that the END1 promoter might be a biotechnological tool to generate malesterile plants for the production of hybrid crop plants.

Tomato male-sterile transgenic plants produced parthenocarpic fruits. This observation suggests that male-sterility in tomato is related to the induction of parthenocarpic fruits.

To identify and characterize cis-regulatory elements involved in the promoter strength and specificity, expression analysis were performed using constructs containing the END1 promoter, modified by deleting different nucleotide sequences, and the $\beta$-glucuronidase gene. Our results reveal that the 5 ' region $-336 /-6$ is sufficient to direct properly the spatial and temporal END1 gene expression and also, suggest that the END1 might be a target gene of floral organ identity genes of classes $\mathrm{B}$ and $\mathrm{C}$.
\end{abstract}





\section{Resum}

END 1 és un gen de pèsol (Pisum sativum L.) específic d'antera que comença a expressarse des d'estadis primerencs del desenvolupament (primordi d'antera) en aquelles línies cel/lulars que donaran Iloc als teixits epidèrmics, connectiu, capa intermèdia i endoteci, i en aquests teixits una vegada desenvolupats. La regió promotora d'aquest gen és capaç de dirigir l'expressió específica del gen uidA (GUS) a les anteres de plantes de diferents espècies (Arabidopsis thaliana, Nicotiana tabacum i Lycopersicon esculentum). El patró d'expressió del gen GUS en aquestes plantes és similar al del gen END1 en pèsol. Aquesta especificitat que confereix el promotor d' END 1 per a l'expressió d'un gen forà les anteres oferia la possibilitat d'utilitzar-lo, fusionant-lo a un gen citotòxic, com una ferramenta biotecnològica per a l'obtenció de plantes transgèniques androestèrils.

En aquest treball, hem fusionat la regió 5' completa (-2736/-6) del promotor d' END1 a la seqüència codificant de la ribonucleasa extracel/lular produïda per Bacillus amyloliquefaciens, barnasa. Amb aquesta construcció hem transformat dos plantes model, Arabidopsis i tabac i una planta d'interés agronòmic, la tomata. L'expressió del gen citotòxic barnasa a on END1 és actiu, porta com a conseqüència una degeneració de teixits de l'antera que va inhibir el desenvolupament dels grans de pollen. Les plantes transgèniques resultants foren androestèrils. Els estudis a nivell histològic de les anteres transgèniques mostraren que els efectes de la barnasa comencen a observar-se molt prompte en el primordi d'antera, quant aquest está constituït només per cèl/lules indiferenciades, i continua observant-se al llarg del desenvolupament de la mateixa. De forma general, al final del programa de desenvolupament, les anteres transgèniques eren de menor mida , la seua morfologia era diferent de la de les anteres silvestres corresponents, i al seu interior s'observava el teixit connectiu col lapsat i una estructura amorfa en lloc de grans de pol·len viable. La possible pèrdua de les cèl-lules parietals primàries per l'acció ribonucleasa podria estar afectant la diferenciació de les cèlllules esporògenes,contigües en el territori del futur microesporangi. Aquests resultats mostren que el promotor d' END1 podria ser una ferramenta biotecnològica útil en els programes d'obtenció de llavors híbrides de diferents cultius d'interès agronòmic.

En el cas particular de la tomata, totes les plantes transgèniques androestèrils produïren fruits partenocàrpics. Aquestresultat mostra que existeix una relació entre l'androstèrilitat i el desenvolupament atònom de l'ovari en eixa espècie.

D' altra banda, s' ha realitzat una anàlisi del promotor del gen END1. Per a aquesta anàlisi és realitzaren delecions successives de la regió $5^{\prime}$ del gen i els fragments resultants es fusionaren transcripcionalment al gen delator uidA (GUS). Amb estes construccions és transformaren plantes de $A$. thaliana i es va estudiar l'expressió del gen uidA mitjançant 
l'assaig histoquímic de l'activitat de la beta-glucuronidasa. Hem vist que el fragment de 366/-6 de la regió 5 ' ès la seqüència mínima amb capacitat per a dirigir la correcta expressió espacial i temporal de gen END1. La pèrdua de l'expressió de GUS en les anteres de les plantes d'Arabidopsis thaliana transformades amb el fragment de la regió 5 ' a on és elimina el motiu CArG2, recolza la hipòtesi que END1 podria estar regulat directament pels gens d'identitat d'òrgan de la classe B i C. 
INTRODUCCIÓN 



\section{DESARROLLO REPRODUCTIVO EN ANGIOSPERMAS. FUNCIÓN REPRODUCTORA DE LA FLOR.}

La transición floral es un evento clave en el ciclo de vida de las plantas con flores (angiospermas). Como consecuencia de este proceso ocurren una serie de cambios morfológicos en los ápices de los tallos que conducen a la formación de las flores. Éstas son estructuras complejas, generalmente compuestas por sépalos, pétalos, estambres y un pistilo (Figura1), cuyo papel consiste en asegurar la producción de los gametos masculinos y femeninos que tras la fertilización darán lugar a la formación de los frutos y semillas.

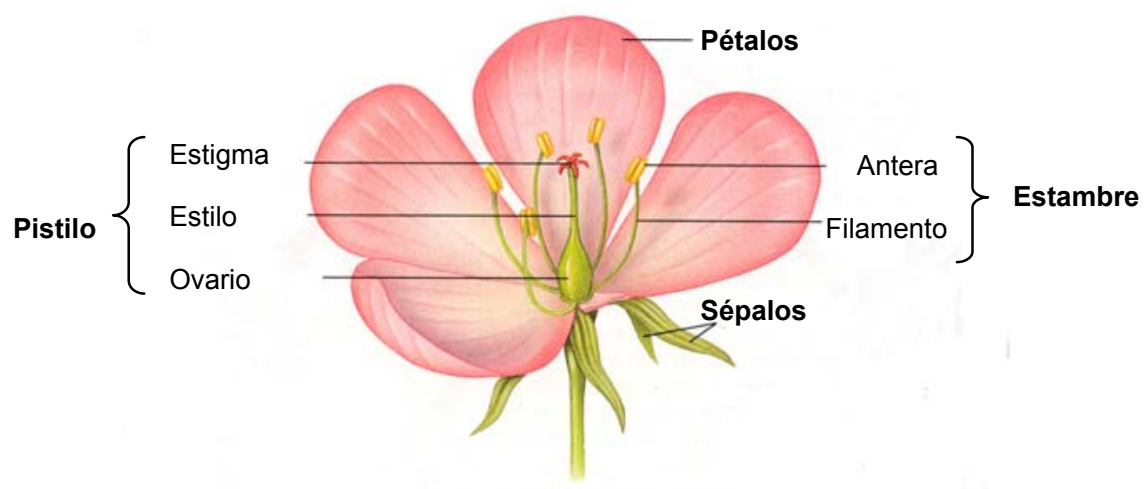

Figura 1. Estructura general de una flor.

\subsection{ONTOGENIA, ESTRUCTURA Y FUNCIÓN DE LA FLOR}

Los órganos de la parte aérea de las plantas, excepto los cotiledones, derivan del meristemo apical del tallo. Durante la fase vegetativa del desarrollo, el meristemo apical del tallo diferencia órganos laterales vegetativos, como primordios de hojas y yemas asilares que posteriormente darán lugar a brotes laterales. En respuesta a señales externas e internas se produce la transición floral, es decir la fase vegetativa finaliza y comienza la fase de desarrollo reproductivo. El meristemo apical del tallo adquiere la condición de meristemo infloreciente, el cual inicia meristemo floral en sus márgenes. Cada meristemo floral producirá a su vez, primordios de órganos florales dispuestos en verticilos concéntricos y cada primordio se diferenciará en un tipo de órgano de la flor adulta. En las plantas de especies modelo como Arabidopsis thaliana y Antirrhinum majus, la iniciación de los primordios de órganos florales es un proceso centrípeto y secuencial (Smyth et al., 1990; Sommer et al., 1990), de manera que primero se forman los primordios de sépalos, después los primordios de pétalos, inmediatamente seguidos de los primordios de estambres $\mathrm{y}$, finalmente, la parte central del meristemo floral forma el primordio de carpelo. 
Sin embargo, en otras plantas como en el caso de las leguminosas, la ontogenia floral ocurre de manera diferente (Figura 2). En estas plantas el orden de la iniciación de los órganos florales es unidireccional en todos los verticilos, comenzando desde la posición abaxial. Al igual que en las especies modelo antes citadas, en la flor de guisante (Pisum sativum L.) los primordios de sépalos son los primeros en iniciarse. Sin embargo, los primordios de estambres y pétalos no se producen directamente a partir del meristemo floral, sino que éste genera cuatro estructuras, los primordios comunes, a partir de los cuales se diferenciarán los primordios de pétalos y los de estambres (Tucker, 1989; Ferrándiz et al, 1999). Dos de los primordios comunes se forman en las posiciones laterales, y los otros dos en posición abaxial y adaxial respectivamente. El primordio del carpelo comienza a formarse al mismo tiempo que los primordios comunes, esto es antes de la diferenciación de los primordios de pétalos y estambres.

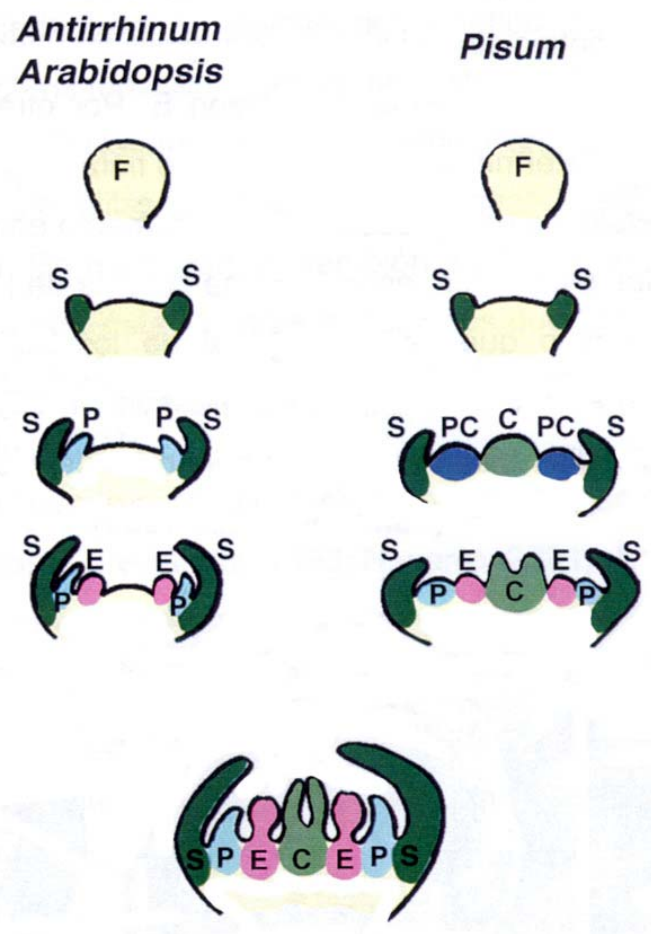

Figura 2. Esquema comparativo del desarrollo floral en Arabidopsis, Antirrhinum y Pisum. F, Meristemo Floral; S, Sépalo; PC, Primordio Común; P, Pétalo; E, Estambre; C, Carpelo.

Al final de cualquiera de los dos procesos de ontogenia floral descritos, se obtienen flores con patrones generales de distribución de órganos y tejidos similares. La identidad de los órganos producidos es diferente en cada verticilo, de manera que, desde fuera hacia dentro, el primer verticilo se halla ocupado por los sépalos, el segundo por los pétalos y el 
tercero y cuarto verticilo por los estambres y el pistilo respectivamente. Los estambres y el pistilo son los órganos reproductores de la flor.

La fase gametofítica del ciclo de vida de las plantas ocurre dentro de los órganos reproductores (Figura 3). En la antera del estambre se producen los granos de polen, que constituyen el gametofito masculino haploide y en el ovario del pistilo se produce la formación de los óvulos, que contienen la generación haploide gametofítica femenina: el saco embrionario. La fusión de los gametofitos masculinos y femeninos en un proceso denominado fertilización dará lugar a la formación del fruto y las semillas (Figura 3).

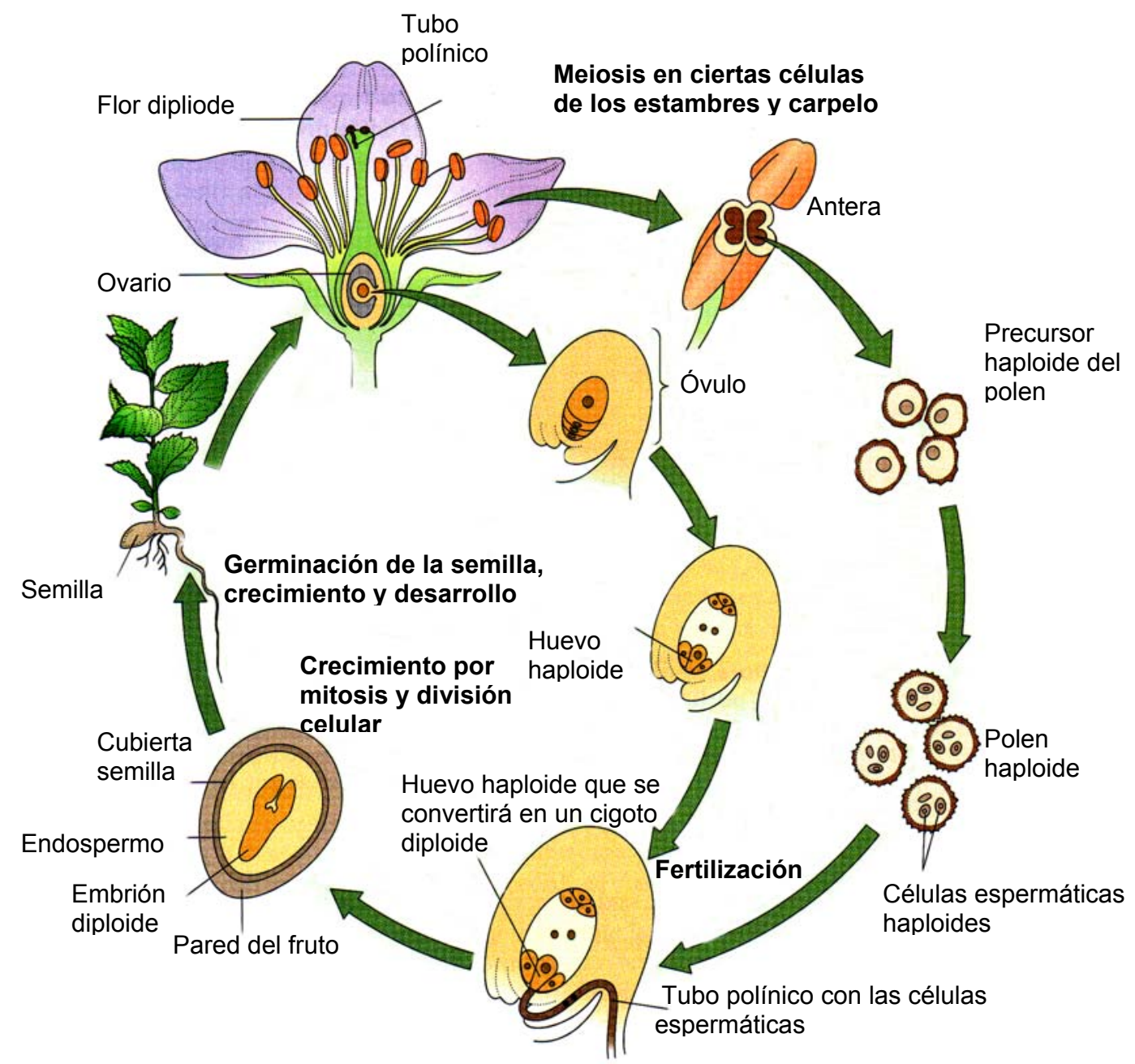

Figura 3. Ciclo de vida de las plantas con flores. (Esquema tomado de Manset, 1998). 


\subsection{ESTRUCTURA DEL ESTAMBRE}

El estambre está constituido por la antera y el filamento. La antera es el sitio donde se desarrollan los granos de polen, y el filamento sostiene a la antera, colocándola en una posición adecuada para facilitar la dispersión del polen. Además, sirve como conducto de agua y nutrientes (Scott et al., 2004) (Figura 4).

La antera está generalmente compuesta por cuatro microsporangios o sacos polínicos dispuestos en pares (tecas). En una sección transversal de una antera diferenciada, se puede observar que los miembros de cada par están separados entre sí por un tejido esporofítico diploide denominado conectivo. Los granos de polen, que se encuentran en el interior de los microsporangios, están aislados del exterior por varias capas de tejidos que en conjunto forman la pared de los sacos polínicos (Koltunow et al., 1990) (Figura 4 B).

A $\quad$ B

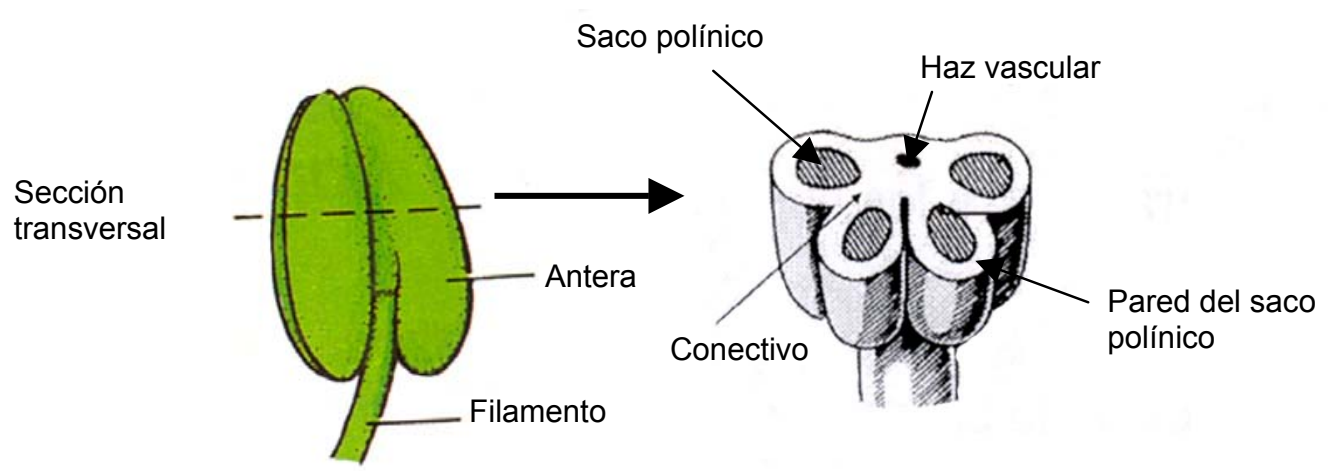

Figura 4: Partes del estambre (A). Sección transversal de una antera (B).

\subsection{DESARROLLO DE LA ANTERA}

El patrón básico de diferenciación de la antera es muy similar entre distintas especies de angiospermas (Scott et al., 1991b). La descripción de los procesos de diferenciación celular y el proceso de ontogenia de los microsporangios que se detalla a continuación, es aplicable de manera general a la mayoría de las dicotiledóneas.

El desarrollo de la antera se puede dividir en dos fases. Durante la fase 1 , se establece la morfología de la antera, ocurre la diferenciación de las células y tejidos que la conforman, y las células madre del polen experimentan la meiosis (Figura 5). Al final de esta fase, la antera contiene la mayoría de sus células y tejidos especializados, y dentro de los sacos polínicos están presentes las tétradas de microsporas. La fase 2 de desarrollo incluye la diferenciación de los granos de polen, el crecimiento de la antera y la extensión del 
filamento, la degeneración de tejidos, la dehiscencia y la liberación de los granos de polen (Figura 5) (Goldberg et al., 1993).

\section{Fase 1.}

Tal como ocurre en el meristemo apical del que derivan las células del primordio de antera, las células del mismo están dispuestas en tres capas concéntricas denominadas L1, L2 y L3 (Satina et al., 1940) (Figura 6).
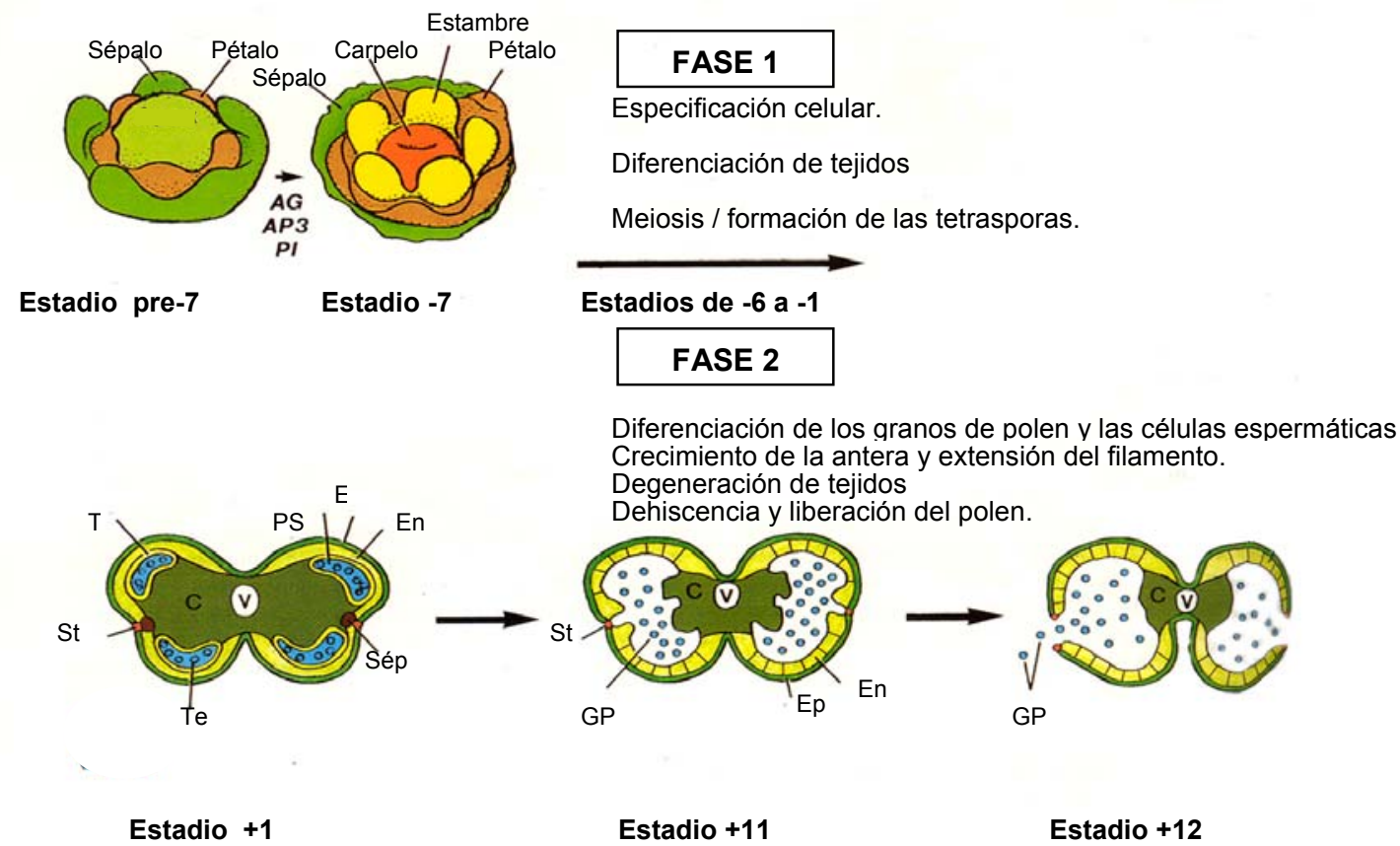

Figura 5. Esquema general del desarrollo de la antera. Representación esquemática de los estadios de desarrollo de la antera y secciones transversales basadas en los estudios del desarrollo de la antera de tabaco realizados por Koltunow et al. (1990) y Drews et al. (1992). C, conectivo; En, endotecio; E, epidermis; Gp, granos de polen; PS, sacos polínicos; Sép, séptum; St, estomio; T, tapetum; Te, tétradas; V, haz vascular. (Esquema tomado de Goldberg et al. (1993).

Cada uno de los tejidos y tipos celulares de la antera derivan de una única capa, aunque las capas L2 y L3 contribuyen conjuntamente a la formación del tapetum. La figura 7 muestra una representación esquemática del primordio de antera y las líneas celulares que se derivan de cada una de las capas que lo componen. La capa L1 da lugar a la epidermis y el estomio, la capa L2 da lugar a las células arquesporiales, las células madre de las microsporas, el endotecio, el tapetum externo y la capa intermedia. La capa L3 da lugar al tejido conectivo, el tapetum interno, el haz vascular y el septum.

Las células arquesporiales que aparecen en las cuatro esquinas de la capa L2 del primordio estaminal, sufren divisiones periclinales que dan lugar a una capa parietal subepidérmica primaria y una capa esporógena interna primaria. Las células de la capa 
parietal primaria se dividen periclinalmente para dar lugar a tres capas concéntricas que constituirán el endotecio, la capa intermedia y el tapetum más externo. En paralelo, las células esporógenas dan lugar a los microsporocitos (células madre de las microsporas) después de varias divisiones mitóticas (Figura 6).

En este estadio, las células madre de las microsporas están rodeadas de una pared delgada de callosa ( $\beta$-1,3-glucano). Éstas, experimentan la meiosis para dar lugar a tétradas de microsporas (Figura 8).

A

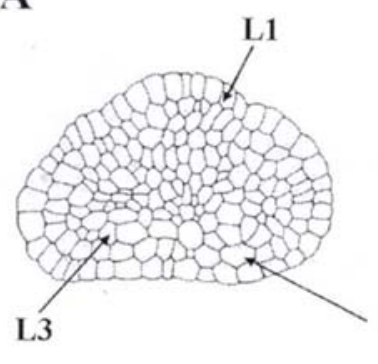

B

L2

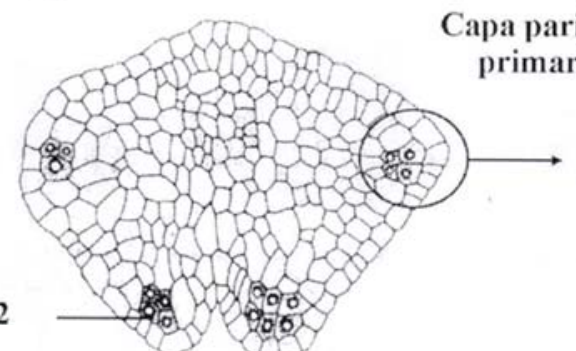

C

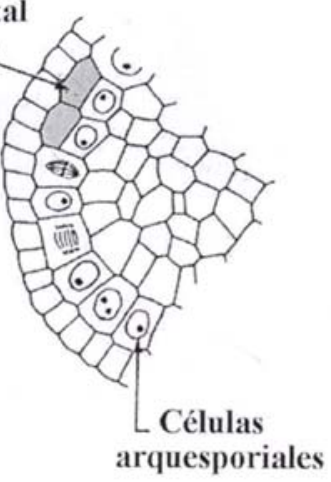

D

\section{Células}

arquesporiales

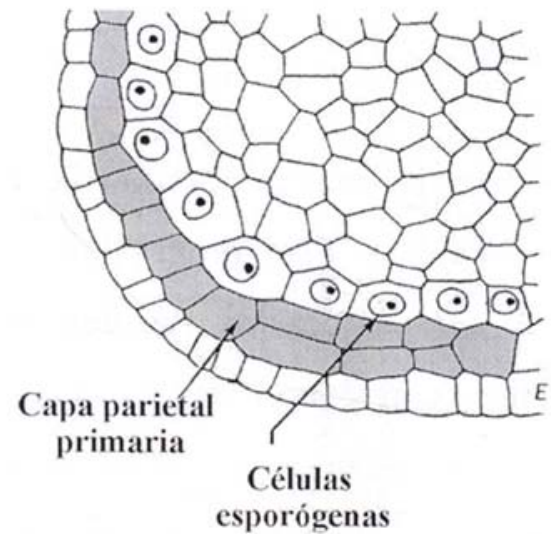

E

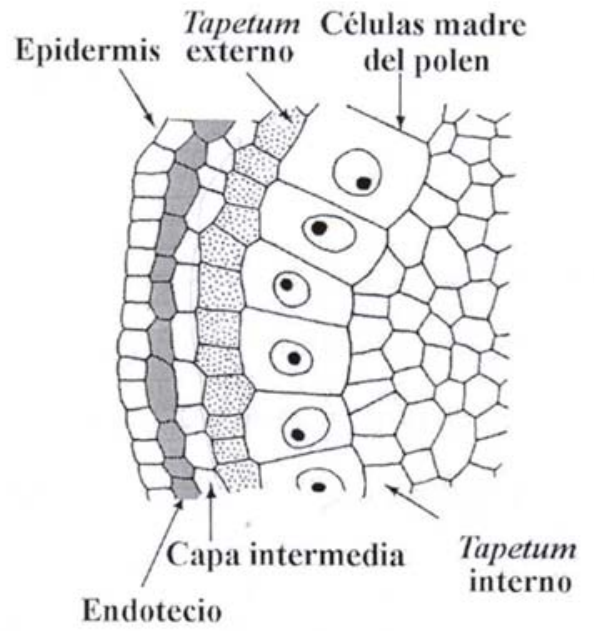

Figura 6. Diferenciación progresiva de las capas celulares L1, L2 y L3 de un primordio estaminal en los distintos tejidos que constituyen un microsporangio (A-E).

Al final de la fase 1 del desarrollo, la antera ya tiene la mayoría de los tejidos y células especializadas responsables de llevar a cabo las funciones reproductoras y no reproductoras. Dentro de los tejidos no reproductores se incluyen la epidermis, endotecio, capa intermedia, tapetum, septum, conectivo, estomio y haz vascular. 

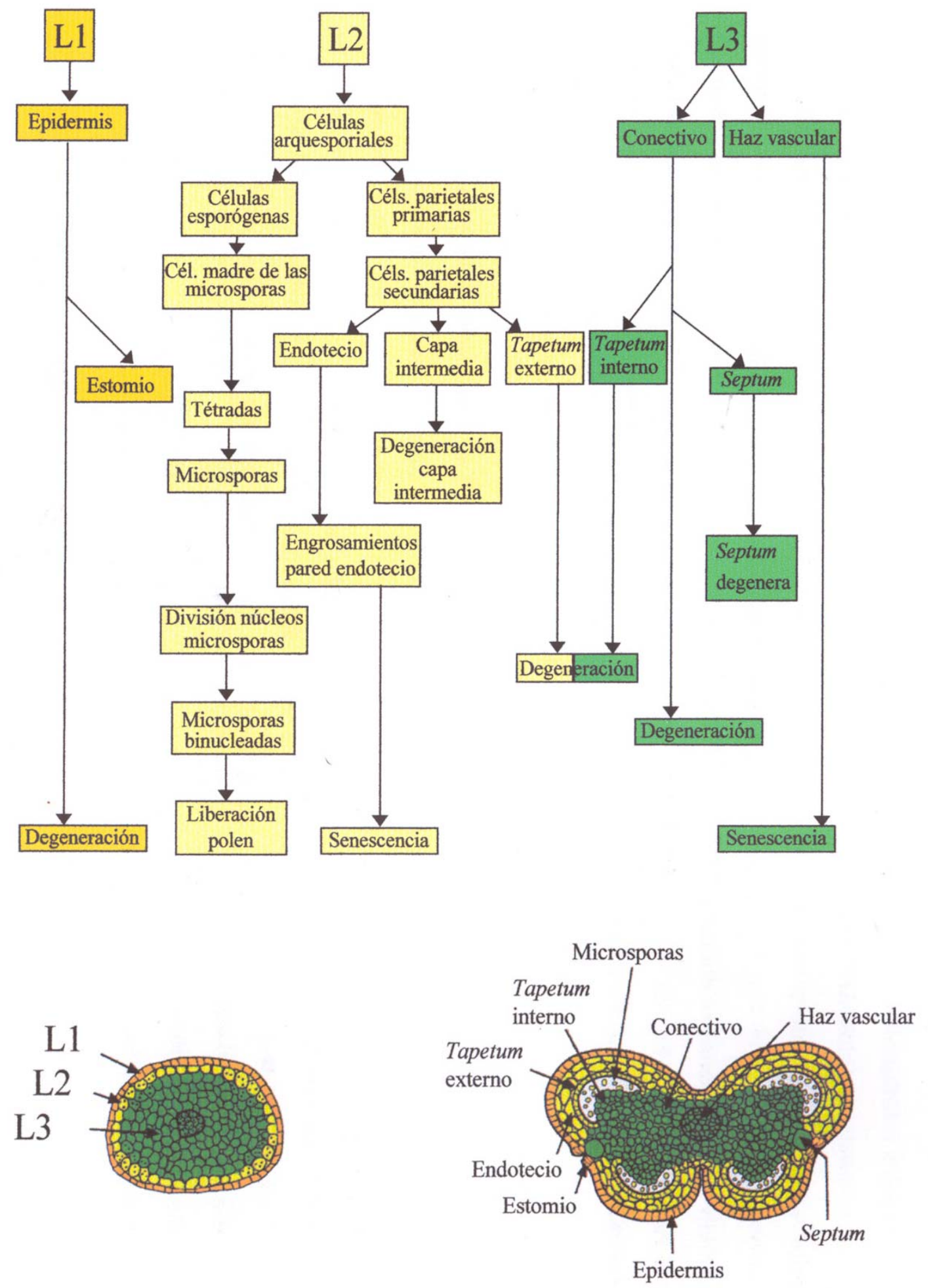

Figura 7. Esquema de los procesos de diferenciación y dehiscencia de la antera. (Esquema tomado de Goldberg et al. (1993). 
La epidermis es la capa más externa de la antera e interviene en la estructura y soporte de la misma, al igual que el endotecio. Además, la epidermis previene la pérdida de agua e interviene en el intercambio de gases y en el proceso de dehiscencia. La capa intermedia ayuda a dar soporte a la estructura de la antera. El tapetum tiene una importante función nutritiva en el desarrollo de los granos de polen. El septum y el estomio están involucrados en la dehiscencia y el tejido conectivo es responsable de mantener unidas a las tecas de la antera y conecta a éstas con el filamento. El haz vascular es el responsable de conectar la antera, el filamento y la flor.

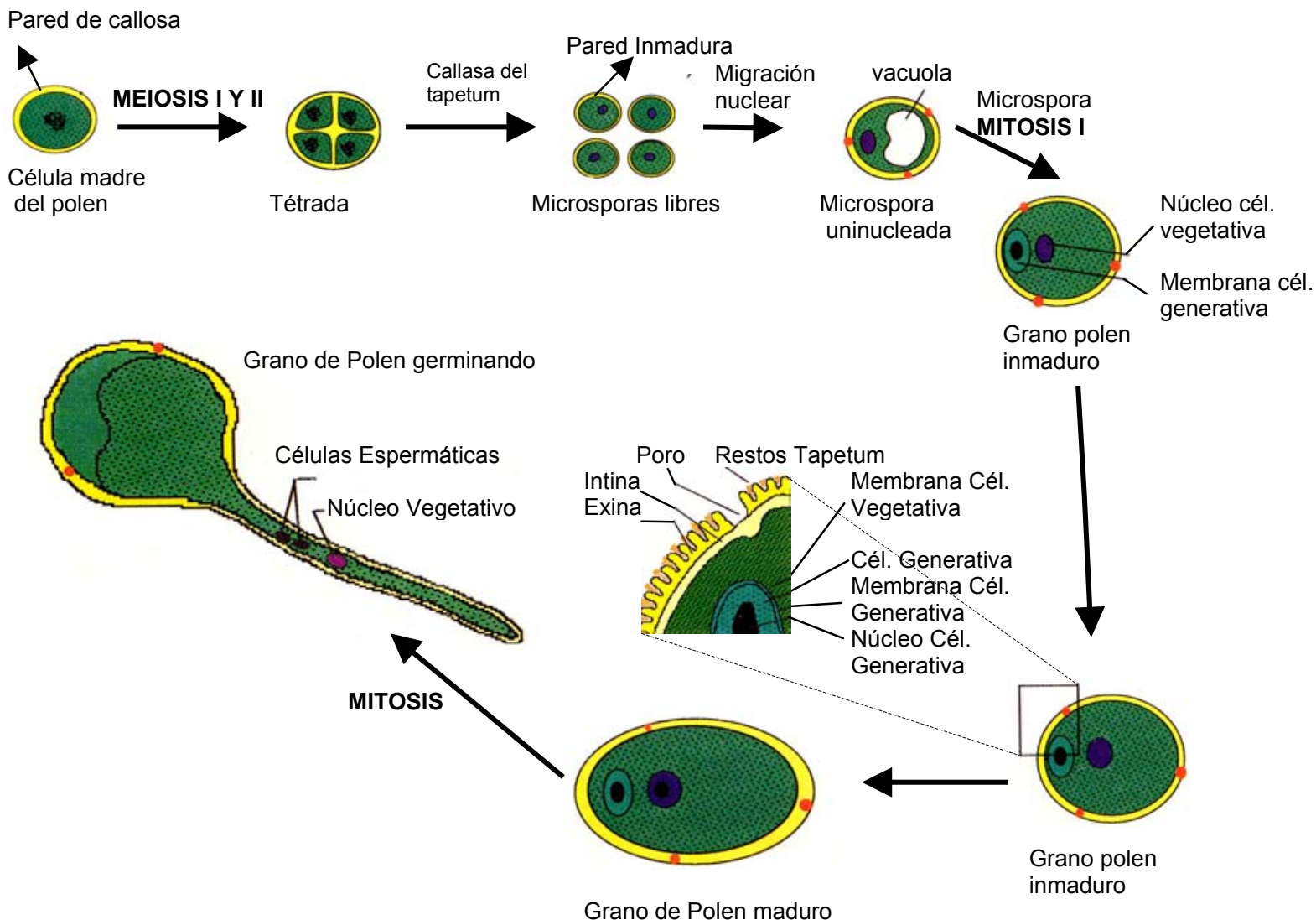

Figura 8. Esquema de la microsporogénesis y microgametogénesis típica de angiospermas. (Esquema tomado de Mc Cormick, 1993).

\section{Fase 2.}

El tapetum secreta callasa ( $\beta-1,3$-glucanasa) que se requiere para la disolución de la pared de callosa que rodea las tetrasporas, y por tanto, para la liberación de las mismas al saco polínico (Figura 8). En el estadio de tétrada se inicia la síntesis de las dos paredes externas del polen, la intina y la exina La exina está compuesta de uno de los polímeros más resistentes conocidos. Además de la función protectora, la pared de exina juega un papel 
importante en la adhesión del polen a la superficie estigmática del pistilo para el comienzo de la polinización (Twell, 2002).

Las microsporas uninucleadas libres sufren una primera división mitótica asimétrica, dando lugar a un grano de polen inmaduro con dos células: una célula vegetativa y una pequeña célula generativa (Figura 8 ). La célula generativa tiene un núcleo condensado y una cantidad de citoplasma reducida, mucho menor que el que contiene la célula vegetativa. Una segunda división mitótica en la célula generativa se produce para dar lugar a las células espermáticas. En la mayoría de las plantas, esta división ocurre mientras el tubo polínico crece a través de los tejidos trasmisores del pistilo (McCormick, 1993).

El programa de dehiscencia de la antera comienza después de la formación de las tétradas de miscrosporas y consiste en una destrucción secuencial de determinados tipos celulares. Este proceso se halla coordinado temporalmente con el de la diferenciación del polen (Figura 7). El programa de dehiscencia incluye varios eventos: 1) la degeneración de la capa intermedia y el tapetum, 2) la expansión del endotecio y formación de bandas fibrosas en las paredes del mismo y células del tejido conectivo, 3) la degeneración del septum que conlleva a la conversión de los sacos polínicos de cada teca en un lóbulo simple, 4) la ruptura de la antera por el estomio y liberación de los granos de polen (Sanders et al., 1999).

\subsection{POLINIZACIÓN Y FERTILIZACIÓN}

La polinización es el primer paso en la formación de las semillas. Este proceso incluye la liberación de los granos de polen de la antera, la deposición de éstos en el estigma del pistilo y el crecimiento del tubo polínico a través del estilo hacia los óvulos del ovario para dar lugar posteriormente a la fertilización (Wilcock y Neiland, 2002).

El pistilo está compuesto de un estigma que está conectado al ovario mediante una estructura conocida como estilo (Figura 9 A). La célula vegetativa del grano de polen, que rodea a las células espermáticas, germina sobre la superficie del pistilo y desarrolla un tubo polínico que transporta los gametos masculinos desde el estigma a los óvulos del ovario. El tubo polínico avanza a través de los tejidos diploides femeninos del estilo extendiendo su extremo inferior a través de ellos (Cheung y Wu, 2001). 
A

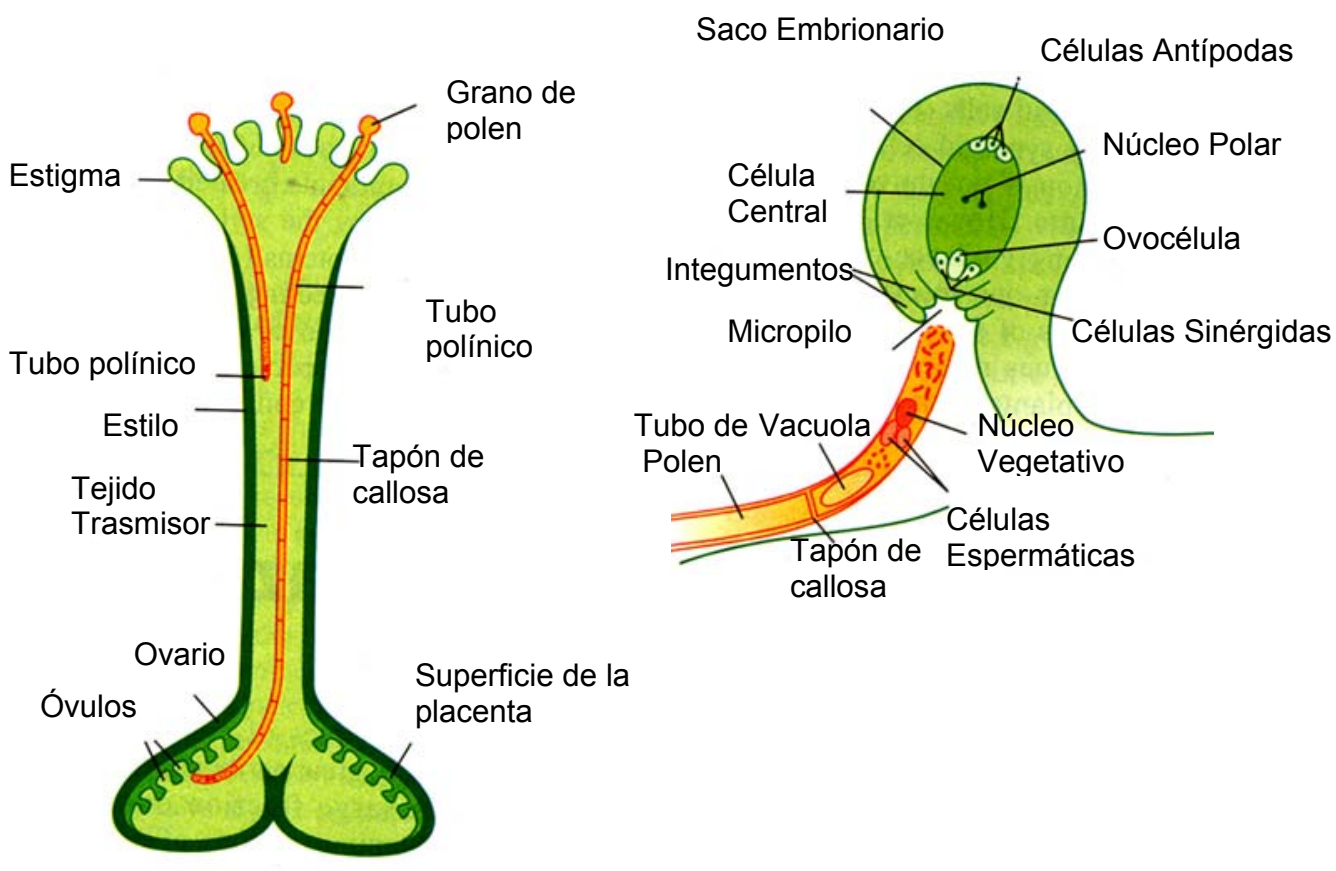

Figura 9. Representación esquemática de la polinización y la fertilización. A, Grano de polen en la superficie del estigma que desarrolla un tubo polínico para avanzar a través del estilo hacia el ovario. B, Cuando un tubo de polen se acerca al micropilo del óvulo y penetra al saco embrionario por el par de células sinérgidas. (Esquema tomado de Cheung y Wu. (2001).

El gametofito femenino (saco embrionario) reside en el óvulo y está compuesto de siete células haploides que incluyen un par de células sinérgidas, una ovocélula, tres células antípodas y la célula central con dos núcleos polares (Figura 9 B). Al llegar al ovario, el tubo de polen ajusta su crecimiento para acceder a un óvulo a través de una apertura llamada micropilo (Figura 9 B). Aunque múltiples tubos polínicos pueden alcanzar el micropilo, usualmente sólo uno consigue penetrar el saco embrionario. Llegado a este punto, se produce la ruptura del extremo inferior de tubo polínico y la salida de los gametos masculinos, que se fusionan con la ovocélula y la célula central binucleada en un proceso de doble fertilización, produciendo respectivamente el embrión y el endospermo triploide de la futura semilla (Cheung y Wu, 2001). 


\section{CONTROL GENÉTICO DE LA IDENTIDAD DE LOS ÓRGANOS FLORALES}

\subsection{MODELO ABC}

Durante el desarrollo de la flor, el meristemo floral genera primordios de órganos que adquieren una disposición en verticilos concéntricos. La identidad de los órganos producidos es diferente en cada verticilo.

Existe un grupo de genes, reguladores de la identidad de los órganos florales, también conocidos como genes homeóticos florales, que son los responsables de especificar la identidad de los órganos que se desarrollan en los diferentes verticilos de la flor. Las mutaciones en estos genes, dan lugar a cambios de identidad en los distintos órganos, provocando que se desarrolle un órgano en el lugar donde debería desarrollarse otro tipo de órgano.

El análisis genético y molecular de los mutantes homeóticos florales en las especies modelo de Arabidopsis y Antirrhinum condujo a la propuesta de un modelo genético, conocido como modelo $\mathrm{ABC}$, que trata de explicar como se determina el destino de un primordio de órgano floral. (Schwarz- Sommer et al., 1990; Bowman et al., 1991; Coen y Meyerowitz, 1991; Meyerowitz et al., 1991; Weigel y Meyerowitz, 1994). El modelo ABC (Figura 10) propone que la identidad de los distintos órganos florales está gobernada por tres clases de genes: A, B y C, responsables de tres tipos de actividades o funciones. Los genes homeóticos de función $A$ especifican la identidad de los sépalos, las funciones $A$ y $B$ juntas especifican la identidad de los pétalos, las funciones $B$ y $C$ juntas la de los estambres y la función $C$ sola especifica la identidad del carpelo. Este modelo propone además que las funciones $\mathrm{A}$ y $\mathrm{C}$ se reprimen mutuamente, de manera que cuando una de ellas no está presente, la otra se expande al resto de verticilos. Así, los genes de función A excluyen a la función $C$ de los verticilos más externos (verticilos 1 y 2) y los genes de clase $C$ excluyen la función $A$ de los verticilos más internos (verticilos 3 y 4 ). Con estas premisas del modelo $A B C$ se explican la mayoría de las alteraciones en la identidad de los órganos florales de los mutantes homeóticos simples, dobles y triples (Bowman et al., 1991, 1993). Sin embargo, debido entre otras cosas a que los genes de identidad de órgano realizan funciones adicionales a la de especificación de los órganos florales, algunos defectos fenotípicos en estos mutantes no pueden explicarse por el modelo ABC.

Las mutaciones homeóticas que alteran la identidad de los órganos florales afectan a la identidad de dos verticilos adyacentes. En función de las características fenotípicas de los mutantes homeóticos, éstos han sido agrupados en tres clases (Figura 10). Los mutantes de pérdida de función A presentan alteraciones en el primer y segundo verticilo, de manera que en lugar de los sépalos se forman órganos carpeloides y en lugar de los pétalos órganos estaminoides. Los mutantes de pérdida de función B presentan afectados el 
segundo y tercer verticilo, de manera que los pétalos se convierten en órganos sepaloides y los estambres en órganos carpeloides. Por último, los mutantes de pérdida de función $\mathrm{C}$ muestran afectados el tercer y el cuarto verticilo, de modo que los estambres se desarrollan como pétalos y los carpelos como sépalos. Recientemente se ha demostrado que en Arabidopsis, la actividad de los genes de identidad de órgano de clase B y C requieren de las actividades de tres genes MADS relacionados entre sí denominados SEPALLATA 1/2/3 (SEP 1/2/3, previamente denominados AGL2, AGL4 y AGL9, respectivamente; Ma et al., 1991; Mandel y Yanofski, 1998) (Pelaz et al., 2000; Honma y Goto, 2001). Se ha propuesto la denominación de genes de función $\mathrm{E}$ para estos nuevos genes de identidad de órgano floral (Theissen y Saedler, 2001). Por otra parte, se ha mostrado que en Arabidopsis, la actividad de los genes SEEDSTICK (STK) y SHATERPROOF 1 y 2 (SHP1 y SHP 2) determinan la identidad de los óvulos, por lo que se ha propuesto la denominación de genes de clase $D$, ya que se puede considerar a los óvulos como órganos florales independientes (Pinyopich et al., 2003).

\section{Arabidopsis Antirrhinum}

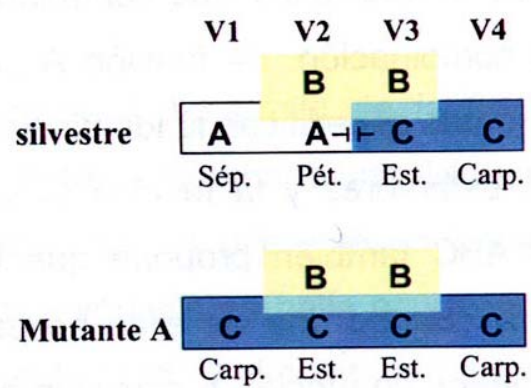

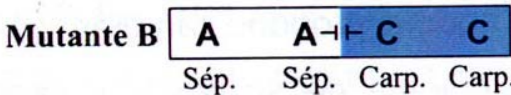

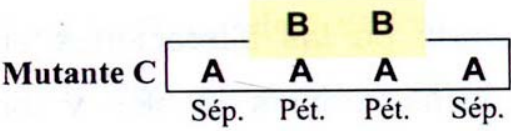

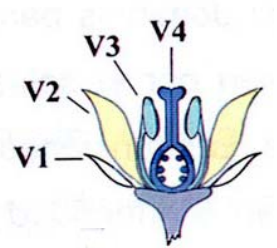

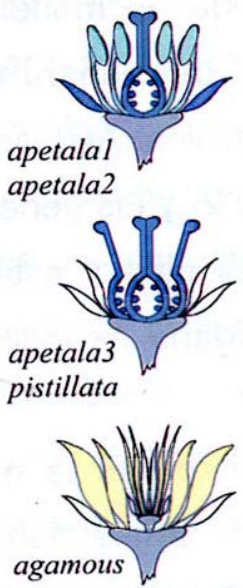

Figura 10. Esquema del modelo ABC. Tres funciones homeóticas que actúan en dominios parcialmente solapantes, A (en blanco), B (en amarillo) y C (en azul), controlan la identidad de los distintos órganos en los verticilos florales $(\mathrm{V})$. La combinación de las funciones $\mathrm{B}$ y $\mathrm{C}$ se muestra en azul-verdoso. Los rectángulos coloreados representan la relación espacial entre las distintas funciones en flores de fenotipo silvestre y mutantes (sólo se representa la mitad de la flor). En los esquemas florales están representados los cambios en la identidad de órganos, así como los efectos en la determinación central que tienen lugar en los tres tipos de mutantes. Los nombres de los mutantes de clase A, B y C de Arabidopsis y Antirrhinum están indicados junto a los esquemas florales. V1, V2, V3 y V4: verticilos 1, 2, 3 y 4 respectivamente, numerados desde el exterior al 
interior de la flor. Sép, sépalo. Pét, pétalo. Est, estambre. Carp, carpelo. (Esquema modificado tomado de Davies et al. (1999b).

En Arabidopsis, los genes APETALA1 (AP1) (Irish y Sussex, 1990) y APETALA2 (AP2) (Jofuku et al., 1994), además de actuar como genes de identidad de meristemo floral, funcionan como genes de clase A. Sus mutaciones afectan a dos aspectos propios de la función $A$ : especificación de los órganos del primer y segundo verticilo y restricción del dominio funcional de la función $\mathrm{C}$. Hasta hace muy poco, no se conocían genes de función A en Antirrhinum. Recientemente, se han identificado dos genes de Antirrhinum, LIP1 y LIP2, con similitud de secuencia a $A P 2$ y que ejercen funciones similares al gen de Arabidopsis. Sin embargo, mientras que en Arabidopsis AP2 controla las dos funciones propias de un gen de clase A, en Antirrhinum el control de estas funciones se ejerce separadamente. Los genes LIP participan en el establecimiento y desarrollo de los sépalos y los pétalos pero no en la represión de la función C. En el doble mutante lip1 lip2 de Antirrhinum no se observa la expresión ectópica de genes de clase $\mathrm{C}$ en los verticilos externos de la flor. Además, no se dan las transformaciones homeóticas de sépalos y pétalos que se observan en los mutantes de clase A de Arabidopsis (apetala1 y apetala2) (Keck et al., 2003). Los fenotipos de los mutantes de clase B y C de Arabidopsis y Antirrhinum sí son comparables, aunque revelan ciertas diferencias que apuntan a diferentes mecanismos de control. La función $\mathrm{B}$ en Arabidopsis está constituida por los genes APETALA3 (AP3) (Jack et al., 1992) y PISTILLATA (PI) (Goto y Meyerowitz, 1994) y en Antirrhinum, por DEFICIENS (DEF) (Sommer et al., 1990) y GLOBOSA (GLO) (Tröbner et al., 1992). La función C la definen los genes AGAMOUS (AG) (Yanofsky et al., 1990) para Arabidopsis y PLENA (PLE) (Bradley et al., 1993) para Antirrhinum.

En otras especies se han descrito mutantes homeóticos florales que muestran fenotipos similares a los descritos para Arabidopsis y Antirrhinum. Así mismo, se han identificado genes de clase $B$ y $C$ que muestran similitud funcional y estructural con los de Arabidopsis y Antirrhinum (Davies y Schwarz- Sommer, 1994). Estos datos sugieren que el control de la identidad de los órganos florales es similar en diferentes especies. La mayoría de las proteínas codificadas por los genes de identidad de órgano floral de Arabidopsis y Antirrhinum con la excepción de AP2, pertenecen a la familia de los genes MADS-box. Las proteínas codificadas por los genes de esta familia son factores transcripcionales que se caracterizan por la presencia de un dominio N-terminal denominado caja MADS. Este dominio consiste en una secuencia de 56 aminoácidos con un alto grado de identidad entre todas las proteínas de este grupo. Se ha demostrado que este dominio conservado es necesario para la unión a DNA in vitro y es importante, aunque no absolutamente esencial, para la dimerización (Schwarz- Sommer et al., 1990; Shore y Sharroks, 1995; Pellegrini y Richmond, 1995; Davies et al., 1996; Riechmann et 
al., 1996 a, b; Riechmann y Meyerowitz, 1997). Las proteínas MADS-box se unen a secuencias de DNA conocidas como cajas CArG, cuya secuencia consenso es 5'CC(A/T) 6 GG-3' (Schwarz- Sommer et al., 1992; Huang et al., 1993; Shiraishi et al., 1993; Shore y Sharrocks, 1995).

\subsection{GENES QUE CONTROLAN LA IDENTIDAD DEL ESTAMBRE}

El primordio de estambre se diferencia en un lugar específico del meristemo floral. El número de primordios de estambre varía entre las diferentes especies de plantas pero su localización en el meristemo floral está fijada en el tercer verticilo. Las mutaciones homeóticas que afectan la identidad de los primordios de sépalo y pétalo, no afectan la iniciación ni diferenciación del primordio de estambre (Coen, 1991). Por lo tanto, la especificación del primordio de estambre ocurre independientemente de la presencia de los primordios de otros órganos florales y viceversa.

La especificación del primordio de estambre está controlada por la interacción de los genes homeóticos de clase $\mathrm{B}$ y $\mathrm{C}$, como AP3, PI y AGAMOUS en Arabidopsis y sus homólogos en Antirrhinum DEF, GLO y PLENA. (Schwarz-Sommer et al., 1990; Coen, 1991; Coen y Carpenter, 1993; Okamuro et al., 1993). La mutación de cualquiera de los genes de clase $\mathrm{B}$ y $\mathrm{C}$ da como resultado la pérdida del primordio de estambre y la conversión del tercer verticilo a un tipo diferente de órgano floral. Por ejemplo, la mutación de los genes $A P 3$ o $P I$ en Arabidopsis, produce la conversión de los pétalos en estructuras sepaloides y de los estambres en estructuras carpeloides, y la mutación del gen $A G$ produce la conversión del tercer verticilo en pétalos y la del cuarto verticilo en sépalos (Figura 10). La mutación simultánea de ambos tipos de genes transforma los estambres en sépalos. Recientemente se ha mostrado que, en Arabidopsis, la función de los genes B y C requiere de la actividad de las proteínas de tipo MADS-box codificadas por los genes SEPALLATA (SEP) (Pelaz et al., 2000; Honma y Goto, 2001). Las mutaciones simples de los genes SEP tiene fenotipos muy tenues, pero en el triple mutante sep1 sep2 sep3, todos los órganos florales son sepaloides, lo que sugiere que la pérdida de la expresión de los genes SEP suprime las funciones B y C (Pelaz et al., 2000).

Se han identificado genes de tipo $B$ y $C$ en diversas especies que muestran gran similitud estructural y funcional con los de las especies modelo antes descritos. Por ejemplo, los genes de clase B de manzano y de arroz, MdPI (Yao et al., 2001) y OsMADS4 (Kang et al., 1995), respectivamente, presentan alta homología de secuencia con miembros de la familia del gen PI de Arabidopsis. Así mismo, la pérdida de función del gen OsMADS4 en plantas transgénicas de arroz, causó conversiones homeóticas de los órganos florales del segundo y tercer verticilo (Kang et al., 1998). La mutación del gen MdPI produce flores similares a 
las del mutante pistillata $(p i)$ en las que los pétalos se transforman en sépalos y los estambres en carpelos (Yao et al., 2001).

En tomate, Brassica napus y arroz se han identificado los genes TAG1 (Pnueli et al., 1994), BAG1 (Mandel et al., 1992) y OsMADS3 (Kang et al., 1995), respectivamente. Estos genes presentan homología con el gen $A G$ de Arabidopsis y sus patrones de expresión están restringidos a los estambres y al carpelo. La función de los genes TAG1 y OsMADS3 fue estudiada por expresión antisentido de los mismos en plantas transgénicas. Estas plantas produjeron flores anormales con alteraciones homeóticas en los dos verticilos internos de la flor (Pnueli et al., 1994; Kang et al., 1998). Con la expresión constitutiva del gen $B A G 1$ se generaron plantas transgénicas de tabaco que produjeron flores con transformaciones de sépalos en carpelos y de pétalos en estambres (Mandel et al., 1992), fenotipo consistente con el esperado para la expresión ectópica de genes de clase $C$.

Aunque la caracterización de los diversos genes y mutantes florales de clase $\mathrm{B}$ y $\mathrm{C}$ ha mostrado que la regulación de la identidad de los pétalos, estambres y el carpelo en diferentes especies se produce de manera similar a la descrita para Arabidopsis y Antirrhinum, se pueden apreciar ciertas diferencias en el número de genes implicados en una función determinada o en la regulación y función de los mismos. Un ejemplo de esto es la existencia de cuatro genes de función $\mathrm{B}$ en petunia: FBP1 y pMADS2, homólogos a GLOIPI, y GREEN PETALS (GP) y PETUNIA HYBRIDA TM6 (phTM6), homólogos a DEFIAP3 (Angenent et al., 1992, 1993; van der Krol et al., 1993; Kramer e Irish, 2000; Vandenbussche et al., 2004). Se ha demostrado que mutaciones en el gen GP causa transformaciones homeóticas en el verticilo de pétalos pero no en los estambres (van der Krol et al., 1993). Por otra parte, los niveles de expresión de FBP1 y pMADS2 son reducidos en el segundo verticilo de flores mutantes gp pero no en los estambres, lo que sugiere que la regulación de la función $B$ es diferente entre el segundo y tercer verticilo en flores de petunia (van der Krol et al, 1993). En lo que respecta a la función C, se ha descrito la existencia de dos genes MADS de clase $C$ en algunas especies. Por ejemplo, los genes CUM1 y CUM10 en pepino (Kater et al., 1998), NAG y NPLE en tabaco (Kempin et al., 1993), ZAG1 y ZMM2 en maíz (Schmidt et al., 1993; Mena et al., 1996), GAG1 y GAG2 en gerbera (Yu et al., 1999) y PTAG1 y PTAG2 en Populus trichocarpa (Brunner et al., 2000). En Antirrhinum, el gen $F A R$ podría ser un componente adicional de la función $C$ que actúa en el mismo proceso de desarrollo que PLENA (Davies et al., 1999a). Sin embargo, en Arabidopsis sólo se ha descrito la existencia de un único gen de función C, AGAMOUS.

Recientemente, en nuestro laboratorio se ha confirmado que el gen PEAM1 ( $\underline{P E A} \underline{M A D S}$ 1) es un homólogo funcional de guisante del gen $P I$ de Arabidopsis. PEAM1 presenta homología de secuencia con genes de identidad de órgano floral de clase $B$ y las flores de las plantas de Arabidopsis y tabaco con expresión constitutiva de este gen muestran 
cambios en la identidad de los órganos florales similares a los mostrados por plantas 35S::PI y 35S::GLO de Arabidopsis y tabaco, respectivamente. Además, se ha visto que la expresión constitutiva de PEAM1 rescata los defectos florales causados por la mutación fuerte pi-1 (Berbel, 2002). Por otra parte, también se han aislado en nuestro laboratorio los genes MADS de guisante PEAM7 y PEAM8, que presentan homología de secuencia con la de los genes del grupo AG (Theissen et al., 2000). El patrón de expresión de estos genes coincide también con el descrito para genes de función $C$ ya que se expresan en los dos verticilos internos de la flor. La expresión constitutiva de PEAM7 y PEAM8 en plantas de Arabidopsis apoyan la hipótesis de una posible función de los mismos como genes de clase C (Navarro, 2001).

\subsection{GENES DIANA DE LAS PROTEÍNAS MADS-BOX IMPLICADOS EN LA DIFERENCIACIÓN DEL ESTAMBRE}

Los genes de identidad de órganos florales codifican factores transcripcionales cuya función molecular es, con toda probabilidad, la regulación de la expresión, directa o indirecta, de genes que se expresan específicamente en los órganos florales y que ejercen funciones concretas dentro de ellos. Estos genes diana pueden ser otros factores transcripcionales, genes que participan en procesos básicos de las células o genes que intervengan en los procesos de morfogénesis floral.

La identificación de los genes regulados por los genes de identidad de órgano floral es crucial para la comprensión de los mecanismos moleculares que conducen a la especificación de órganos y la diferenciación de células y tejidos (Zik e Irish, 2003). Esta identificación es técnicamente dificultosa (Graba et al., 1997), por lo que hasta el momento se han identificado pocos genes diana de las proteínas MADS-box. Algunos de los primeros genes diana de genes MADS-box que se identificaron fueron, precisamente, otros genes MADS-box. Se halla bien establecido que los genes que confieren la función $B$ en Arabidopsis, AP3 y PI, y en Antirrhinum, DEF y GLO, se autorregulan por los heterodímeros de sus propios productos, AP3-PI y DEF-GLO, respectivamente. El mantenimiento de la expresión de estos genes depende de la disponibilidad de las dos proteínas de clase $\mathrm{B}$ en estado funcional (Goto y Meyerowitz, 1994; Jack et al., 1994; Krizek y Meyerowitz, 1996; Schwarz-Sommer et al., 1992; Tröbner et al., 1992; Zachgo et al., 1995). Se ha comprobado la unión in vitro del heterodímero PI/AP3 al promotor de AP3 (Hill et al., 1998; Tilly et al., 1998). Sin embargo, en el caso de PI no existen cajas CArG en su promotor, por lo es posible que su autorregulación sea indirecta. También se ha visto que el heterodímero DEF/GLO se une in vitro a las cajas CArG de los promotores de los dos genes que lo 
codifican (Davies et al., 1996; Schwarz-Sommer et al., 1992; Tröbner et al., 1992 ; Zachgo et al., 1995).

El gen de clase $\mathrm{C}$ de Arabidopsis, AGAMOUS, cuya mutación afecta tanto la especificación de los estambres como la del carpelo, podría interactuar directamente con el promotor del gen AGL5, perteneciente a la familia MADS-box, cuya expresión se observa desde estadios tempranos del desarrollo del carpelo. Savidge et al. (1995) demostraron que los niveles del transcrito de AGL5 se hallan drásticamente reducidos en flores del mutante agamous. Estos autores encontraron en la región 5' del gen AGL5 una posible caja CArG de secuencia similar al consenso del sitio de unión específico para la proteína AG y demostraron la unión in vitro de esta proteína a un fragmento del promotor de AGL5 donde se encontraba la posible caja CArG. Además, observaron que al expresar constitutivamente $A G$ se activó la expresión ectópica de AGL5 en hojas caulinares. Con esto demostraron que $A G$ es un regulador positivo de $A G L 5$, que la interacción entre ambos puede ser directa y que AG es suficiente para activar a AGL5 en ausencia de otros factores específicos de carpelo.

Se ha postulado al gen SUPERMAN (SUP, también llamado FLO10), requerido para mantener la frontera entre el tercer y cuarto verticilo de la flor, como candidato a gen diana de AP3/PI y AG. Su expresión es reducida en mutantes ap3 y pi, y en el mutante fuerte ag, no se detecta la expresión de SUP en el tercer verticilo en estadios tardíos del desarrollo floral. Todo esto ha demostrado que para el mantenimiemto de la expresión de SUP se requieren los genes $A P 3, P I$ y $A G$ pero no se ha demostrado que la regulación sea directa (Sakai et al., 2000).

Se han usado técnicas de comparación de perfiles transcripcionales, en combinación con mutantes o plantas transgénicas con las funciones $\mathrm{B}$ y $\mathrm{C}$ alteradas, para tratar de identificar los genes diana de los correspondientes genes homeóticos de función B y C. Por ejemplo, la hibridación diferencial de una librería de cDNA enriquecida en inflorescencias se usó para aislar mRNAs expresados en flores silvestres pero no en mutantes def de Antirrhinum que carecen de la función $B$. Con estos experimentos se identificaron 12 genes expresados diferencialmente, entre los que se incluye el gen TAP1, que se expresa en el tapetum y codifica para una proteína de secreción, y el gen FILAMENTOUS FLOWER1 (FIL1), que se expresa fundamentalmente en el filamento del estambre y en la base de los pétalos y codifica proteínas de pared celular (Nacken et al., 1991).

Sablowski y Meyerowitz (1998), desarrollaron un método para la identificación de genes diana de los genes homeóticos que intervienen en la especificación del estambre en Arabidopsis, AP3 y PI. La estrategia que utilizaron se basa en la detección de mRNAs cuyos niveles aumentaron rápidamente en respuesta a la activación de la función $B$ en los órganos florales. Para ello, usaron flores ap3-3; ag-3; 35S::PI; 35S::AP3-GR. Estas flores 
carecen de la función B pero expresan constitutivamente $P I(35 S:: P I)$ y la proteína de fusión entre el polipéptido AP3 y el receptor de glucocorticoide de rata, GR (35S::AP3-GR). La fusión de GR a la proteína AP3 impide su entrada al núcleo y con ello el funcionamiento del complejo AP3/PI. La aplicación de dexametasona libera a AP3-GR del citoplasma, permitiendo su entrada al núcleo y la formación y actuación del complejo AP3-GR/PI. De esta manera, se permite la transcripción de aquellos genes cuya actividad depende del heterodímero y que se halla inhibida por la ausencia de actividad de AP3. Para descartar la regulación de genes cuya transcripción no se activa directamente por AP3/PI sino por otro factor de transcripción activado por dicho heterodímero, los autores trataron las plantas con cicloheximida, un inhibidor de la síntesis de proteínas. El efecto inmediato de la activación de AP3/PI en la población de mRNAs fue analizado por "differential display". De esta manera, se identificó un gen al que se denominó NAP. La caracterización de dicho gen mostró que su expresión es más fuerte en los dominios donde actúa AP3/PI y que no tiene lugar en mutantes ap3-3. Además, se ha comprobado en experimentos in vitro que el heterodímero AP3/PI se une a una caja CArG que este gen contiene en su primer intrón. $N A P$ supuso el primer gen para el cual se comprobó su regulación directa por un gen homeótico.

Recientemente, Zick e Irish (2003) han empleado la línea transgénica desarrollada por Sablowski y Meyerowitz (1998), en combinación con micromatrices de DNA, en unos experimentos encaminados a realizar una identificación global de genes regulados por $A P 3$ y Pl. La expresión de los genes fue comparada en flores de plantas silvestres y en flores mutantes y transgénicas con la función B alterada. En este estudio se identificaron 47 genes que podían estar regulados directa o indirectamente por el heterodímero AP3/PI en el desarrollo de pétalos y/o estambres. Entre estos genes, sólo dos resultaron ser factores de transcripción. Veintiocho de los 47 genes identificados, tienen una o más posibles cajas CArG en sus secuencias 5', lo que sugiere que, efectivamente, podrían estar activados directamente por este heterodímero.

\subsection{GENES DE EXPRESIÓN ESPECÍFICA EN ESTAMBRE.}

La gametogénesis masculina es un proceso de gran relevancia biológica pero además tiene un elevado interés desde el punto de vista aplicado puesto que es una diana a modificar para regular la androesterilidad de las plantas cuando se pretenda obtener semillas híbridas. Este doble interés ha motivado el aislamiento de genes activos en diferentes tipos celulares y/o diferentes estadios durante la diferenciación y desarrollo de la antera.

Además, las secuencias reguladoras de genes específicos de tejidos de la antera, se pueden utilizar en técnicas de ablación genética para determinar la función de un tipo 
determinado de célula, así como para comprender si los procesos de interacción y comunicación entre los diferentes tipos celulares juegan algún papel en los procesos de diferenciación celular (Day e Irish, 1997).

Se han aislado genes relacionados con el desarrollo del estambre mediante el rastreo de mutantes con fertilidad masculina reducida. En Arabidopsis, muchos de estos mutantes se han generado por mutagénesis de insersión, lo que ha hecho posible aislar con relativa facilidad los genes mutados (Bhatt et al., 2001). Entre los genes identificados mediante esta estrategia se encuentran los genes MS5 (Glover et al., 1998), ASK1 (SKP1-LIKE1) (Yang et al., 1999a), y POLLENLESS3 (Sanders et al., 1999), que están asociados específicamente con la meiosis masculina. El factor de transcripción SPOROCYTELESS/NOZZLE (Schiefthaler et al., 1999; Yang et al., 1999b), es fundamental durante la meiosis masculina y femenina. El gen MALE STERILITY2 (MS2) (Aarts et al., 1993) está implicado en la formación de la pared del polen y se expresa en el estadio de liberación de las microsporas. El gen MALE STERILITY1 (MS1), que se expresa en el tejido tapetal desde el estadio de microspora libre, parece ser esencial para la gametogénesis masculina. Su mutación da como resultado plantas con androesterilidad absoluta por la ausencia de polen viable (Wilson et al., 2001). Las mutaciónes de los genes EMS1 (Zhao et al., 2002) y ABORTED MICROSPORES (AMS) (Sorensen et al., 2003) provocan esterilidad masculina, ya que estos genes están relacionados con la diferenciación de los microsporocitos y las células tapetales, respectivamente. El gen NEF1 está relacionado con la formación de la pared de exina en los granos de polen y su mutación provoca anormalidades en las microsporas desde el estadio de microspora libre (Ariizumi et al., 2004). El gen TPD1 se requiere para la formación de las células tapetales, de manera que las anteras del mutante tdp1 carecen de tapetum (Yang et al., 2003). Por otra parte, también se han aislado genes específicos de antera y de polen de diversas especies utilizando métodos de rastreo diferencial en librerías de cDNA de dichos tejidos. Es de destacar que varios de los genes específicos de antera aislados de estas librerías mostraron expresión fundamentalmente en el tapetum (Scott et al., 1991a; Smith et al., 1990; Koltunow et al., 1990). Durante el desarrollo temprano de la antera, es en las células del tapetum donde más activa es la transcripción y la alta representación de mensajeros de tapetum refleja la gran actividad metabólica de este tejido en los estadios iniciales del desarrollo de este órgano (Scott et al., 1991b;2004).

Los promotores de diversos genes específicos de antera se han utilizado para la expresión de otros genes en los tejidos donde estos promotores son activos. Por ejemplo, los promotores específicos de tapetum de los genes $A 3$ y $A 9$ de Arabidopsis (Scott et al, 1991a), se fusionaron a una glucanasa "modificada" y con este gen quimérico se transformaron plantas de tabaco. Las plantas transgénicas expresaban prematuramente la glucanasa modificada proveniente del tapetum, y como consecuencia mostraron diferentes 
grados de esterilidad masculina. Estos resultados demostraron que la degradación de la pared de callosa del microsporocito causa androesterilidad y sugiere que la callosa es esencial para la formación de una pared celular normal en las microsporas (Worral et al., 1992).

La secuencia promotora de otro gen, el Osg6B, aislado de arroz, se fusionó a una glucanasa de soja y el gen quimérico se introdujo en tabaco. El promotor de Osg6B comienza a ser activo en el tapetum durante la formación de las tétradas. En este caso, la actividad glucanasa en el tapetum de las anteras de las plantas transgénicas causó una reducción significtiva en el número de granos de polen fértiles. Estos resultados demostraron que la disolución prematura de la pared de callosa en el estadio de tétrada también causa androesterilidad y sugiere además que el tiempo en el cual se activa la glucanasa producida en el tapetum es crítico para el desarrollo normal de las microsporas (Tsuchiya et al., 1995).

Para examinar el papel de la célula vegetativa en el comportamiento de la célula generativa durante la diferenciación del grano de polen se usó la secuencia promotora del gen LAT52 de tomate. Estudios previos habian demostrado que este gen era activo en el polen maduro y específicamente en la incipiente célula vegetativa, inmediatamente después de la mitosis I del polen. La secuencia reguladora de LAT52 se utilizó para dirigir la expresión de la cadena $A$ del gen de la toxina de la difteria (DTA), y la construcción resultante se introdujo en plantas de tabaco. El análisis de los transformantes demostró que la expresión de la DTA en estos tejidos conduce a la letalidad del polen. Con análisis histológicos detallados, se comprobó que la pérdida de función de la célula vegetativa causa que la migración de la célula generativa desde la pared del polen al citoplasma de la célula vegetativa sea anormal. Estos resultados demostraron la dependencia de la célula generativa del polen de las funciones de la célula vegetativa y, sobre todo, pusieron de manifiesto la importancia de las interacciones entre ambas en el control de la migración de la célula generativa (Twell, 1995).

Beals y Goldberg (1997), para determinar qué tipos celulares de una antera están implicados en el proceso de dehiscencia, usaron promotores específicos de tejidos involucrados en este proceso fusionados al gen barnasa y al gen barstar, la ribonucleasa extracelular del Bacillus amyloliquefaciens y su inhibidor específico, respectivamente. Para ello cruzaron plantas de tabaco transformadas con dos tipos de construcciones. La primera construcción contenía el gen barnasa bajo el control del promotor TA56 de tabaco, de manera que con ella se provocaba la destrucción del septum, el estomio y el haz vascular. El otro tipo de construcción estaba formado por el gen barstar bajo uno de los siguientes promotores: a) el promotor TP12 de tabaco, activo en casi todos los tejidos de la antera, b) el promotor TA20, activo también en casi todos los tejidos de la antera pero con un patrón 
de expresión distinto a TP12, o C) el promotor del gen de la lectina de soja, activo en células del tejido conectivo, del septum y del estomio desde estadios tempranos de desarrollo. Los promotores usados en cada pareja eran activos en tipos celulares comunes pero el promotor que dirigía la expresión del gen barnasa, lo era en un tipo celular adicional. Las células en las que se expresaban ambos promotores, eran protegidas de la actividad ribonucleasa de la barnasa por la acción de su inhibidor específico, el gen barstar. Aquellas en las que sólo se expresaba el gen barnasa eran destruidas porque barstar estaba ausente. De esta manera, mediante análisis por microscopía óptica de las anteras de las plantas transgénicas que se obtuvieron, se demostró que el proceso de dehiscencia depende sólo de un estomio funcional (Beals y Goldberg, 1997).

Se han usado además varios promotores para dirigir la expresión de genes citotóxicos a las miscrosporas o al tapetum. El promotor PSI, específico de arroz, se fusionó al gen barnasa y la construcción resultante se introdujo en plantas de tabaco. Se obtuvieron plantas transgénicas que mostraban un rango amplio de fenotipos: desde fertilidad reducida a completa esterilidad. Esto indicó que la expresión específica de un gen citotóxico en el polen induce letalidad del mismo y puede conducir a una fertilidad masculina reducida (Zhan et al., 1996).

Se ha demostrado que la ablación del tapetum en diferentes estadios de desarrollo de la antera, tiene distintos efectos en la formación del polen. El uso del promotor específico de tapetum de tabaco TA29 dirigiendo la expresión de los genes citotóxicos DTA y barnasa durante el estadio de tétrada del desarrollo del polen provoca androesterilidad. Esto indica que el tapetum es esencial para la producción de polen viable en este estadio (Mariani et al., 1990). En cambio, la sustitución del promotor TA29 por el promotor APG de Arabidopsis, específico de tapetum en el estadio de microspora del polen, no tiene efectos negativos en el desarrollo del polen de plantas de tabaco. Esto indica que después de la disgregación de las tétradas de microsporas, el tapetum no es esencial para la formación del polen (Roberts et al., 1995). Esta estrategia no sólo ha servido para analizar la importancia de la presencia del tapetum en el desarrollo de los granos de polen en un estadio determinado, sino que está siendo empleada en la actualidad por diversas empresas productoras de semillas para producir plantas androestériles, característica deseable en los procesos de obtención de semillas híbridas (Williams, 1995).

\subsection{ANÁLISIS DE PROMOTORES DE GENES ESPECÍFICOS DE ANTERA}

Se han estudiado diversos genes específicos de antera y sus promotores para analizar los elementos en cis involucrados en la especificidad de su expresión (Ariizumi et al., 2002). Entre estos genes, los más estudiados son los que se expresan específicamente en el 
gametofito masculino (granos de polen), en las células tapetales o en ambos. Esta elección quizás se debe a la importancia del polen en la reproducción sexual de las plantas. Por otra parte, durante la formación y maduración de las miscrosporas, el tapetum es probablemente el tejido metabólicamente más activo de la antera, suministrando nutrientes para el desarrollo de las microsporas, sintetizando enzimas para la disolución de las tétradas y liberando compuestos que son depositados en la exina del polen (Scott et al., 1991b).

Se han utilizado diferentes abordajes para caracterizar los elementos reguladores en cis que controlan la transcripción de estos genes. La expresión transitoria y estable en plantas transgénicas de genes delatores dirigidos por estos promotores ayuda a dilucidar si las secuencias 5' anteriores al inicio de la traducción son capaces de controlar la expresión espacial y temporal de los genes en cuestión. Ensayos de la funcionalidad de deleciones sucesivas de estas secuencias promotoras permiten determinar las secuencias mínimas necesarias para la expresión específica del gen. Se ha observado que pequeños fragmentos de estos promotores son capaces de dirigir la transcripción de los genes delatores (McCormick, 1993). La capacidad de dirigir la transcripción con un patrón espacio-temporal adecuado se mantiene generalmente cuando estos promotores se ensayan en plantas heterólogas (Scott et al., 1991a), lo que indica que los factores que interaccionan con estos promotores están conservados durante la evolución.

Los promotores de los genes de polen LAT52, LAT56 y LAT59 de tomate se han analizado exhaustivamente (Twell et al., 1990, 1991). Se identificaron varios elementos en cis involucrados en la especificidad e intensidad de la expresión usando métodos de expresión transitoria y estable de los genes quiméricos. Los genes quiméricos se introdujeron en polen de tabaco por bombardeo de micropartículas cubiertas de DNA para estudios de expresión transitoria (Twell et al., 1990). Los mismos genes también se transformaron establemente en plantas de tomate y tabaco. Con estos abordajes, la comparación de secuencias y mutagénesis dirigida de las mismas, se han identificado dos importantes elementos reguladores requeridos para la expresión en polen: la caja LAT52/LAT56 (TGTGGTTATATA) y la caja LAT56/LAT59 (GAATTTGTGA), las cuales comparten dos de los promotores de los genes LAT. Dentro de la caja 52/56 y en otros sitios de la secuencia reguladora del gen $L A T 52$, se ha encontrado el motivo PB (TGTGGT). Los motivos "GTGG" y "GTGA" encontrados en las cajas 52/56 y 56/59, respectivamente, se encuentran en otros promotores de polen y mutaciones en los mismos conducen a una disminución de su actividad.

Dentro de la secuencia promotora del gen de tabaco específico de polen NTP303 se identificaron elementos reguladores mediante experimentos de expresión transitoria y estable. Las mutaciones dirigidas a secuencias precisas del promotor mostraron que 
ninguno de los elementos reguladores en cis específicos de polen antes descritos juega un papel clave en la regulación del gen NTP303. A pesar de que en su secuencia se observaron motivos que muestran similitud con el elemento PB encontrado en la secuencia del gen LAT52, se demostró por mutagénesis dirigida que éste no funciona como un elemento regulador positivo. Sin embargo, otras dos regiones fueron capaces de dirigir la expresión temporal y específica del gen en plantas transgénicas de tabaco. En estas regiones se encontró un nuevo elemento regulador. Su secuencia es AAATGA y está conservada en el promotor del gen de Brassica napus Bp10, específico de polen y homólogo de NTP303 (Weterings et al., 1995). Así mismo, se identificó el "elemento Q" (AGGTCA) como elemento cuantitativo en la región reguladora del gen de maíz ZM13, homólogo a LAT52 (Hamilton et al., 1998). Este elemento se encuentra también en el promotor del gen Bp19 de Brassica (Zou et al., 1994). En las secuencias de los promotores de los genes ZM13 y PSI de arroz se ha encontrado otra secuencia reguladora común que contiene los nucleótidos GTCAAAA (Hamilton et al., 1998; Zou et al., 1994). Los genes OlnB4 y OInB3 de Brassica napus, específicos de tapetum, comparten en las secuencias 5' anteriores al inicio de la transcripción, el motivo $C(A)_{6 / 10}$. Esta secuencia aparece en repetidas ocasiones en cada uno de estos promotores (Hong et al., 1997).

En la tabla 1 aparecen relacionados algunos promotores de genes específicos de tapetum, polen o de ambos tejidos. En esta tabla se recogen datos sobre la expresión espacial de estos promotores, los motivos reguladores específicos más importantes encontradas en sus secuencias y la región mínima comprobada capaz de dirigir correctamente la expresión espacial y temporal de dichos genes. 
Tabla 1. Análisis de algunos promotores específicos de antera de diferentes especies.

\begin{tabular}{|c|c|c|c|c|c|}
\hline Especie & Promotor & $\begin{array}{c}\text { Dominio de } \\
\text { expresión }\end{array}$ & $\begin{array}{l}\text { Elementos } \\
\text { reguladores en cis } \\
\text { encontrados }\end{array}$ & $\begin{array}{l}\text { Fragmento } \\
\text { mínimo } \\
\text { activo } \\
\text { comprobado }\end{array}$ & Referencia \\
\hline $\begin{array}{c}\text { A. } \\
\text { thaliana }\end{array}$ & $\begin{array}{l}\begin{array}{l}\text { A9 } \\
\text { TUA1 }\end{array} \\
\text { LPT12 } \\
X T H 3 \\
\text { PGA4 } \\
\text { AVP1 }\end{array}$ & $\begin{array}{l}\text { Ta } \\
\text { Po } \\
\text { Ta } \\
\text { Ta } \\
\text { Ta, Po } \\
\text { Po }\end{array}$ & $\begin{array}{l}\text { n.d } \\
\text { TGTGG (parte del } \\
\text { motivo PB), Caja } \\
56 / 59 \\
\text { Caja 56/59, Motivo PB } \\
\text { Caja 56/59, Motivo PB } \\
\\
\text { Caja 56/59, Motivo PB } \\
\\
\text { AGTCA (similar al } \\
\text { "elemento Q"), Caja } \\
\text { NTP303 (AAATGA) }\end{array}$ & $\begin{array}{l}-353 /-24 \\
-97 /+56 \\
-1095 /-15 \\
-400 /-20 \\
-1145 /-68 \\
-298 /+1\end{array}$ & $\begin{array}{l}\text { Paul et al., } 1992 . \\
\text { Carpenter et al., } \\
1992 . \\
\\
\text { Ariizumi et al., } \\
2002 \\
\text { Ariizumi et al., } \\
2002 . \\
\text { Ariizumi et al., } \\
2002 . \\
\text { Mitzuda et al., } \\
2001 .\end{array}$ \\
\hline $\begin{array}{c}N . \\
\text { tabacum }\end{array}$ & $\begin{array}{l}\text { TA29 } \\
\text { Npg1 } \\
\text { NTP303 }\end{array}$ & $\begin{array}{l}\text { Ta } \\
\text { Po } \\
\text { Po }\end{array}$ & $\begin{array}{l}\text { n.d } \\
\text { Caja 52/56,Caja } \\
\text { 56/59, Motivo PB } \\
\text { Motivo PB, Caja } \\
\text { NTP303 (AAATGA) } \\
\end{array}$ & $\begin{array}{l}-207 /-85 \\
-182 /+85 \\
-103 /+2\end{array}$ & $\begin{array}{l}\text { Koltunow et al., } \\
1990 . \\
\text { Tebbut y } \\
\text { Londsdale, } 1995 . \\
\text { Weterings et al., } \\
1995\end{array}$ \\
\hline $\begin{array}{c}L . \\
\text { esculentum }\end{array}$ & $\begin{array}{l}\text { LAT52 } \\
\text { LAT59 }\end{array}$ & Po & $\begin{array}{l}\text { Caja 52/56, Motivo } \\
\text { PB, Secuencia } \\
\text { GTCAATT } \\
\text { Caja 56/59,Motivo PB }\end{array}$ & $\begin{array}{l}-499 /+113 \\
-1309 /+91\end{array}$ & $\begin{array}{l}\text { Twell et al., 1989, } \\
\text { 1990, } 1991 . \\
\text { Twell et al., 1990, } \\
1991 .\end{array}$ \\
\hline Zea mays & Zm13 & Po & $\begin{array}{l}\text { "elemento Q" } \\
\text { (AGGTCA), secuencia } \\
\text { TGGTTA del motivo } \\
\text { 52/56, secuencia } \\
\text { GTCAAAA }\end{array}$ & $-261 /+61$ & $\begin{array}{l}\text { Hamilton et al., } \\
1998\end{array}$ \\
\hline $\begin{array}{c}\text { Brassica } \\
\text { rapa }\end{array}$ & $\begin{array}{l}\text { Bra r1 } \\
\text { SP11/ } \\
\text { SCR }\end{array}$ & $\begin{array}{l}\text { Po } \\
\text { Ta, Po } \\
\text { Po }\end{array}$ & \begin{tabular}{|l|} 
Motivo GTGA, Motivo \\
PB, Caja 56/59 \\
No se encontraron
\end{tabular} & $\begin{array}{l}-2600 /-16 \\
-192 /-1 \\
-143 /-1\end{array}$ & $\begin{array}{l}\text { Okada et al., } \\
2000 . \\
\text { Shiba et al., } 2001 .\end{array}$ \\
\hline $\begin{array}{l}\text { Oryza } \\
\text { sativa }\end{array}$ & PSI & Po & \begin{tabular}{|l|} 
TGTGG (parte del \\
motivo PB), \\
Secuencia GTCAAAA, \\
"Elemento Q" \\
(ACGTCA) \\
\end{tabular} & $-1700 /+191$ & Zou et al., 1994. \\
\hline
\end{tabular}

Ta, tapetum; Po, polen; n.d, no se han determinado.

\section{PLANTAS ANDROESTÉRILES: USO EN LA AGRICULTURA}

La caracterización de genes específicos de antera tiene gran importancia porque en la antera ocurren los procesos que darán lugar al desarrollo del gametofito masculino. Además, mediante la manipulación de genes específicos de tejidos de la antera se pueden obtener plantas androestériles. La mayor parte de la semilla que se produce con fines 
comerciales es semilla híbrida. Puesto que para la producción de semilla híbrida se utilizan plantas androestériles, la androesterilidad es un carácter de gran interés en la agricultura.

\subsection{SEMILLAS HÍBRIDAS}

El desarrollo de variedades híbridas por compañías de semillas y agricultores implica una importante inversión de tiempo, pericia y dinero. La utilización de métodos de ingeniería genética permite facilitar la obtención de líneas puras androestériles.

Los híbridos son el producto del cruzamiento entre dos individuos genéticamente diferentes y se caracterizan por un mayor valor respecto a sus parentales. Este valor puede estar dado por un mayor vigor, rendimiento y mejor adaptabilidad y uniformidad. Además, tienden a ser más tolerantes a estrés ambiental y más resistentes a enfermedades (Reynaerts et al., 1993). Los agricultores han hecho un amplio uso de este fenómeno para aumentar la productividad de los cultivos, pero las bases biológicas del mismo siguen sin conocerse (Tsaftaris, 1995).

\subsubsection{Métodos para la obtención de semillas híbridas}

Para la producción comercial de semillas híbridas es conveniente disponer de un sistema que evite la autopolinización y que permita obtener la línea parental materna androestéril. Este sistema puede ser mecánico, químico o cualquiera basado en fenómenos que ocurren naturalmente como la esterilidad masculina y la autoincompatibilidad.

Existen diferentes especies donde las plantas masculinas y femeninas están separadas (plantas dioicas) y otras donde las flores masculinas están separadas de las femeninas dentro de una misma planta individual (plantas monoicas unisexuales, ej. maíz). Para estas especies, evitar la autopolinización es relativamente fácil. Sin embargo, muchas especies tienen órganos sexuales masculinos y femeninos muy próximos dentro la flor (flores hermafroditas, ej: colza, cebada, tomate, etc). Para evitar la polinización se puede recurrir a la emasculación manual, donde los órganos masculinos se eliminan de cada flor y el polen proveniente del otro parental se aplica manualmente para producir la semilla híbrida. Esto es una labor ardua y cara, por lo que sólo se producen las semillas de esta manera si la cantidad y el valor de las mismas compensan el esfuerzo.

Un segundo método es la aplicación de productos químicos llamados gametocidas, que destruyen específicamente el polen (método químico). Estos productos producen una androesterilidad transitoria, por lo que este método no es particularmente efectivo en cultivos con un período de floración largo o aquellos en que la floración es poco predecible. 
La producción comercial de semillas híbridas vía gametocida, está limitada por el coste y efectividad de los productos químicos.

En la mayoría de los sistemas de producción de semillas híbridas que se usan para cultivos agrícolas se aprovecha la variabilidad natural que ofrecen algunas líneas de especies que son autoincompatibles o estériles masculinas. Se denominan autoincompatibles a las plantas que son incapaces de autopolinizarse. Aunque la autoincompatibilidad es útil para producir semillas híbridas, hay muchos problemas para propagar las líneas femeninas autoincompatibles. También, en ocasiones, la autoincompatibilidad puede desaparecer como resultado de condiciones ambientales de estrés y esto trae como resultado la contaminación de semillas híbridas con semillas derivadas de la autopolinización.

Las plantas androestériles se usan como parental femenino en los programas de mejora. Éstas deben ser completamente estériles masculinas, pero su fertilidad femenina debe permanecer sin anomalías, tales como defectos en la morfología de los órganos reproductores femeninos, para evitar que se afecte la apariencia del fruto. Así mismo, el carácter de androesterilidad debe ser recesivo ya que no es deseable en la generación híbrida F1 de plantas, donde tanto las semillas como los frutos son considerados productos (maíz, cebada, arroz o tomate) (Gorman y McCormick, 1997). La androesterilidad en plantas con flores es debida a un desarrollo anormal del gametofito masculino que da lugar a polen no viable. Se distinguen dos tipos de androesterilidad en función de su regulación génica: esterilidad masculina nuclear (NMS) o esterilidad mendeliana, en la que una mutación en el genoma nuclear es la responsable de la androesterilidad, y la esterilidad masculina citoplásmica (CMS), que se hereda del parental femenino y se origina como consecuencia de cambios en la organización y expresión del genoma mitocondrial (Williams, 1995). En cualquiera de los tipos de androesterilidad se pueden distinguir tres clases de anomalías fenotípicas: a) androesterilidad estructural, en la cual el tejido microsporógeno no se desarrolla o la microsporogénesis no es completa, b) androesterilidad esporógena, que incluye predominantemente mutantes pre-meióticos, meióticos y post-meióticos y c) androesterilidad funcional, en la que se forma polen viable pero incapaz de fertilizar. La mayoría de las plantas NMS y CMS exhiben el tipo esporógeno de fertilidad (Verdel et al., 1994).

Para producir semillas híbridas suelen emplearse líneas de las plantas CMS. La mayoría de las plantas CMS deben su fenotipo a mutaciones mitocondriales que producen anteras o polen no funcionales. Los sistemas CMS tienen la ventaja de que al heredarse todos los orgánulos de la madre todas las semillas adquieren el carácter androestéril. La fertilidad en fenotipos CMS se puede restaurar utilizando líneas fértiles que aporten genes $R f$ (genes nucleares dominantes que suprimen la mutación mitocondrial). El resultado será una 
progenie F1 híbrida y fértil, aunque las células contengan un citoplasma androestéril (Hanson y Conde, 1985). La restauración de la fertilidad mediante este sistema se está utilizando comercialmente en especies de interés agronómico para producir variedades de semillas híbridas. El uso de este tipo de plantas androestériles conlleva diversos problemas. Algunas líneas CMS son sensibles a condiciones de estrés y sus características de androesterilidad pueden revertir en momentos inoportunos. Hay líneas que son difíciles de mantener, ya que al cruzarlas con otras se restaura su fertilidad, y hay líneas que muestran una esterilidad tan fuerte que no se puede restaurar. Por otra parte, la androesterilidad citoplasmática natural necesita la presencia de un citoplasma específico y la uniformidad citoplásmica que esto ocasiona hace a los cultivos susceptibles a ciertas enfermedades como la del citoplasma T de maíz en 1970 (Kriete et al., 1996). Por último, no se dispone de líneas androestériles citoplásmicas para todos los cultivos usados en agricultura (Kriete et al., 1996).

\subsection{ANDROESTERILIDAD NUCLEAR POR INGENIERÍA GENÉTICA}

\subsubsection{Métodos moleculares usados para la obtención de plantas androestériles}

La utilización de métodos basados en el DNA recombinante y la caracterización de genes implicados en el desarrollo del polen ha permitido el desarrollo de sistemas moleculares que provocan androesterilidad nuclear (NMS) (Scott et al., 1991b; Twell, 1994). En los sistemas moleculares, la androesterilidad se consigue a través de procesos que impiden el desarrollo de las microsporas o de los tejidos que intervengan en su desarrollo.

Se han utilizado diversas estrategias con este fin que pueden ser agrupadas en diferentes clases:

1) Sistemas que dependen de un mecanismo que destruya selectivamente los tejidos necesarios para la producción de polen funcional mediante la expresión de un gen que codifique una proteína capaz de alterar el funcionamiento celular.

Dentro de este grupo se encuentra la estrategia molecular de ablación diseñada por Mariani et al. (1990), donde un promotor específico de tapetum se usó para dirigir la expresión de dos RNasas diferentes (RNasa T1 de Aspergillus oryzae y barnasa de Bacillus amyloliquefaciens) en tabaco y Brassica napus. Las anteras transgénicas que se obtuvieron carecían de tapetum y contenían sacos polínicos vacíos. Podemos citar también dentro de este grupo los métodos desarrollados por O'Keefe et al. (1994) y por Kriete et al. (1996). En el primero, la expresión del citocromo P450 sv1 en las células tapetales de tabaco, transformó un precursor inofensivo del gametocida R7402, añadido de forma exógena, en su forma activa (500 veces más tóxica) y esto dio como resultado la obtención de plantas 
androestériles. Sin embargo, posiblemente debido al rápido metabolismo de R7402, la androesterilidad se limitó a flores de un determinado estadio de desarrollo durante la aplicación del compuesto. El otro sistema de obtención de androesterilidad inducible se basó en la utilización del promotor TA29 específico de tapetum junto con el gen argE de E.coli. El producto de este gen desacetila el compuesto $\mathrm{N}$-acetil-L-fosfinotricina y lo transforma en glufosinato, un compuesto citotóxico. Cuando se aplica sobre la planta de tabaco $\mathrm{N}$-acetil-L-fosfinotricina, el tapetum degenera y se obtienen plantas que no producen polen.

2) Sistemas para producir androesterilidad que introducen un gen o un grupo de genes que producen una alteración en los niveles de ciertos metabolitos o reguladores del crecimiento que interfieren con la producción de polen viable. Entre estas sustancias se encuentran compuestos tales como aminoácidos, carbohidratos, flavonoides, ácido jasmónico, biotina o auxina. Cuando se transformaron plantas de tabaco con una construcción antisentido del gen de tabaco que codifica la invertasa extracelular Nin88 bajo el control de su propio promotor, se indujo esterilidad masculina en plantas de tabaco. Esta invertasa se expresa en las células tapetales de la antera desde estadios tempranos del desarrollo. La reducción de actividad invertasa provocó la interferencia en el suplemento de carbohidratos y esto bloqueó el desarrollo de los granos de polen (Goetz et al., 2001). Las plantas de tabaco que expresan el gen rolB de Agrobacterium rhizogenes bajo el control del promotor tap1 de Antirrhinum, específico de antera, muestran alteraciones morfológicas de las mismas y una reducción del crecimiento de las flores, debido a la alteración en los contenidos de IAA y giberelinas que produce la sobreexpresión de este gen (Spena et al., 1992).

3) La esterilidad masculina también se puede generar por la expresión simultánea de dos transgenes en la misma planta, lo que se logra mediante el cruce de dos líneas parentales diferentes que expresen cada uno de ellos. Un ejemplo de este método es la reconstitución de una toxina activa a partir de dos fragmentos de toxina inactivos, cada uno codificados por un transgén separado. La expresión combinada de ambos transgenes en los tejidos reproductivos masculinos, puede dar como resultado plantas androestériles (Fabijanski y Arinson, 1995).

La biotecnología ha aportado nuevos métodos para obtener plantas androestériles que podrían ser útiles para la producción comercial de semilla híbrida para diferentes cultivos. 


\subsubsection{Inducción de androesterilidad nuclear mediante la expresión de un gen citotóxico}

La primera estrategia molecular para la obtención de esterilidad masculina nuclear fue la propuesta por Mariani et al. (1990) y está basada en la ablación celular, mediante una aproximación de tipo genético. Esta estrategia requiere de tres componentes:

1) Un gen citotóxico que provoca la ablación celular. La ablación celular ocurre en uno o varios tejidos de la antera provocando su degeneración y la consecuente androesterilidad.

2) Un promotor apropiado para dirigir la expresión espacial y temporal del gen citotóxico de modo que conduzca a la ablación específica de tejidos que intervengan en el desarrollo del gametofito masculino.

3) Un gen marcador que se introduce en el genoma de la planta junto al gen quimérico y hace posible rastrear la descendencia estéril masculina sin tener que esperar a que se manifieste el fenotipo androestéril en las flores.

Para la producción comercial de semillas híbridas usando esta estrategia, es necesario añadir un cuarto componente: un gen que inhiba la acción del gen de esterilidad masculina. Este gen se denomina gen restaurador y asegura que la progenie híbrida tenga órganos sexuales masculinos y femeninos capaces de llevar a cabo la fecundación y producir frutos y semillas.

\subsubsection{Ablación celular}

La ablación de células y tejidos específicos ha sido muy utilizada como una herramienta eficaz para el análisis del origen y destino de células específicas, el estudio de las interacciones y comunicaciones entre diferentes tipos celulares así como para la investigación de las funciones de los mismos (Day e Irish, 1997).

Tradicionalmente, la ablación celular se ha llevado a cabo por métodos físicos, tales como microdisección o ablación láser en procesos de desarrollo animal, o genéticamente, mediante el uso de mutaciones que afectan líneas celulares específicas. Estos abordajes han sido usados especialmente en Drosophila y Caenorhabditis elegans (Kimble, 1981; Sulston y White, 1980), pero son difíciles de aplicar a organismos que son menos susceptibles a las manipulaciones físicas o genéticas (Day e Irish, 1997).

Más recientemente, la ablación genética se ha comenzado a llevar a cabo mediante la expresión dirigida del producto de un gen letal por un promotor específico del tejido a destruir. La ablación genética destruye tejidos inaccesibles a la ablación física, así como tejidos que están relacionados funcionalmente pero físicamente dispersos dentro de un organismo (Thorsness y Nasrallah, 1995). 


\subsubsection{Genes citotóxicos}

Los genes citotóxicos codifican proteínas que causan la muerte de las células donde se expresan (Day e Irish, 1997).

Se han usado para ablación genética en plantas diversas proteínas que inducen la muerte celular como la toxina A de la difteria (DTA), la exotoxina A, la RNasa T1 y la barnasa. De manera general, los productos de estos genes son letales porque eliminan la síntesis de proteínas por diferentes mecanismos. La toxina de la Diphteria se produce naturalmente en Corynebacterium diphteriae y se sintetiza como un polipéptido precursor que posteriormente se divide en dos fragmentos, la cadena A y B (Collier, 1975). Tanto la DTA como la exotoxina A de Pseudomonas aeruginosa inactivan los ribosomas, causando la inhibición de la síntesis de proteínas. Las células donde se expresen estas enzimas no se pueden dividir y como consecuencia mueren (Day et al., 1995).

Para la ablación celular en plantas también se han utilizado ribonucleasas como la RNasa T1 de Aspergillus oryzae (Mariani et al., 1990) y la RNasa barnasa del Bacillus amyloliquefaciens (Mariani et al., 1990; Goldman et al., 1994). El efecto tóxico de estos genes es debido aparentemente a la degradación intracelular de RNAs requeridos para la supervivencia de las células (Thorsness y Nasrallah, 1995). En los tejidos donde se expresan estas RNasas, no se detecta la presencia de mRNA. En experimentos realizados en tabaco y Brassica napus, la barnasa actuó como una toxina más potente que la RNasa T1 (Mariani et al., 1990), lo que indica su mayor eficacia para experimentos de ablación celular en plantas. El uso de la barnasa presenta además la ventaja de la disponibilidad de un inhibidor específico de la misma, denominado barstar (Hartley, 1989).

\subsubsection{Barnasa y barstar}

La barnasa es el nombre de una ribonucleasa extracelular producida por Bacillus amyloliquefaciens. Esta proteína consiste de una cadena simple de 110 aminoácidos que no contiene enlaces bisulfuro, y no requiere cationes divalentes $u$ otros componentes no peptídicos para ejercer su función (Hartley y Barker, 1972). Por la simplicidad de su estructura se ha utilizado como sistema modelo estudiar los problemas del plegamiento de las proteínas (Hartley, 1989).

El barstar fue descubierto por Smeaton y Elliott (1967) como el inhibidor específico de la barnasa producido intracelularmente por el mismo organismo. Es una proteína que consta de 89 aminoácidos $\mathrm{y}$, al igual que la barnasa tampoco contiene enlaces bisulfuro, ni requiere de ningún catión divalente u otro componente no peptídico para su función (Hartley y Smeaton, 1973). 
Estas dos proteínas forman un complejo equimolar no covalente : una molécula de barstar se une a una molécula de barnasa, aboliendo su actividad ribonucleasa. Dicho complejo es muy estable, como lo indica el hecho de que se necesita solamente un pequeño exceso de barstar para eliminar la actividad de la barnasa (Hartley y Smeaton, 1973).

La barnasa le sirve al $B$. amyloliquefaciens como una enzima digestiva, degradando RNA exógeno y como una toxina para competidores o depredadores. La función biológica del barstar es proteger al B. amyloliquefaciens del efecto tóxico intracelular de la barnasa. Esto sugiere que el plegamiento de la barnasa no tiene lugar exclusivamente en el espacio extracelular sino que se puede encontrar cierta actividad, quizás debida a síntesis accidental en los ribosomas libres, dentro de la célula (Hartley, 1989).

El gen barnasa es letal para el organismo huésped cuando se expresa solo. Los intentos iniciales de clonarla en E.coli y B.subtilis fueron fallidos y sólo fue posible introducirla en un plásmido de E.coli después de su inactivación en B.amyloliquefaciens por la inserción de un transposón (Paddon y Hartley, 1985) o con la introducción de mutaciones puntuales específicas dentro del gen que provocan su letalidad (Paddon y Hartley, 1987). La ausencia del barstar, que ejerce una función protectora en $B$. amyloliquefaciens, en organismos como E.coli y B.subtilis, es la causa de la letalidad de la barnasa en los mismos.

Cuando se clonó el gen barnasa original con el control de secreción phoA en el mismo plásmido que el gen barstar, se secretó al medio y la enzima recombinante fue similar a la auténtica barnasa (Hartley, 1988). Esto pudo comprobarse al analizar su especificidad enzimática y al realizar pruebas termodinámicas y químicas (Hartley, 1988).

\subsubsection{Uso del sistema barnasa-barstar para la obtención de semillas híbridas}

Toda la producción comercial de semillas híbridas se basa en establecer androesterilidad en una línea que servirá como parental femenino. En los sistemas moleculares, esto se consigue a través de procesos que impidan el desarrollo de las microsporas o de los tejidos que intervienen en su desarrollo.

Como se ha mencionado, la primera estrategia para la obtención de plantas androestériles por ingeniería genética fue descrita por Mariani et al. (1990). Para desarrollar dicha estrategia se fusionó el promotor del gen TA29 de tabaco, específico de las células tapetales que rodean al saco polínico, a dos ribonucleasas diferentes, la RNasa T1 de Aspergillus oryzae y la barnasa de Bacillus amyloliquefaciens. Los genes quiméricos se introdujeron en plantas de tabaco y colza y se obtuvieron plantas transgénicas. Estas fueron idénticas entre ellas y a las plantas control respecto al crecimiento, morfología de los órganos vegetativos y florales y tiempo de floración. Sin embrago, el 10\% de los 
transformantes TA29-RNasaT1, y el 92\% de los transformantes TA29-barnasa, no produjeron granos de polen y por tanto no se obtuvieron ni cápsulas ni semillas. Las flores de estas plantas entraban en senescencia sin llegar a formar fruto; sin embargo sus órganos reproductores femeninos eran funcionales, formando frutos normales después de la polinización con polen de plantas no transformadas.

Cuando se comparó el desarrollo de la antera de las plantas transgénicas estériles con las de anteras de plantas control, no se observaron diferencias desde el estadio de desarrollo 1 (según Koltunow et al. (1990) - yemas florales de 0'8 cm) al estadio 12 (flores abiertas), con respecto a la morfología externa, tamaño, longitud del filamento y color. La única diferencia con las anteras de plantas control fue la ausencia de granos de polen.

El estudio por microscopía de secciones transversales mostró que a partir del estadio 2 de desarrollo de la antera se observan con claridad diferencias entre el tapetum de las anteras transgénicas y las de las plantas control. Las anteras control tienen un tapetum prominente que rodea los sacos polínicos y en el interior de los mismos se desarrollaron granos de polen. En las anteras de las plantas TA29::RNAsa, la ausencia del tapetum provocó el colapso de los sacos polínicos y la ausencia de granos de polen. Todos los demás tejidos y tipos celulares eran idénticos en anteras fértiles y estériles. Estos datos indicaron que la presencia de los genes quiméricos TA29::RNasa destruyen selectivamente el tapetum durante el desarrollo de la antera causando esterilidad masculina en las plantas donde este gen quimérico se exprese.

Por su mayor eficacia en la generación de plantas estériles se seleccionó el sistema TA29::barnasa para la inducción de androesterilidad en plantas. Como también se ha comentado anteriormente, el sistema de la barnasa presenta la ventaja adicional de la existencia de un inhibidor específico y eficaz para la actividad ribonucleasa.

En la figura 11 se ilustra cómo el uso de un gen quimérico basado en el promotor TA29 y la secuencia codificante del gen barnasa conduce a la ablación selectiva de las células tapetales de la antera y, por tanto, a la esterilidad masculina de las plantas transgénicas. Además, se usan plantas transformadas con un gen quimérico "anticitotóxico" que contiene el mismo promotor TA29 y la región codificante del gen barstar. Las plantas resultantes no tienen afectado el desarrollo de las células tapetales, por lo que son fértiles. Cuando las plantas estériles masculinas que contienen el gen TA29::barnasa se cruzan con plantas fértiles que contienen el gen TA29::barstar, se producen plantas fértiles que expresan ambos transgenes (Mariani et al., 1992).

La presencia de barstar dentro de las células tapetales de la progenie F1 restaura la fertilidad masculina por la formación del complejo barnasa-barstar que previene la acción citotóxica de la ribonucleasa. 


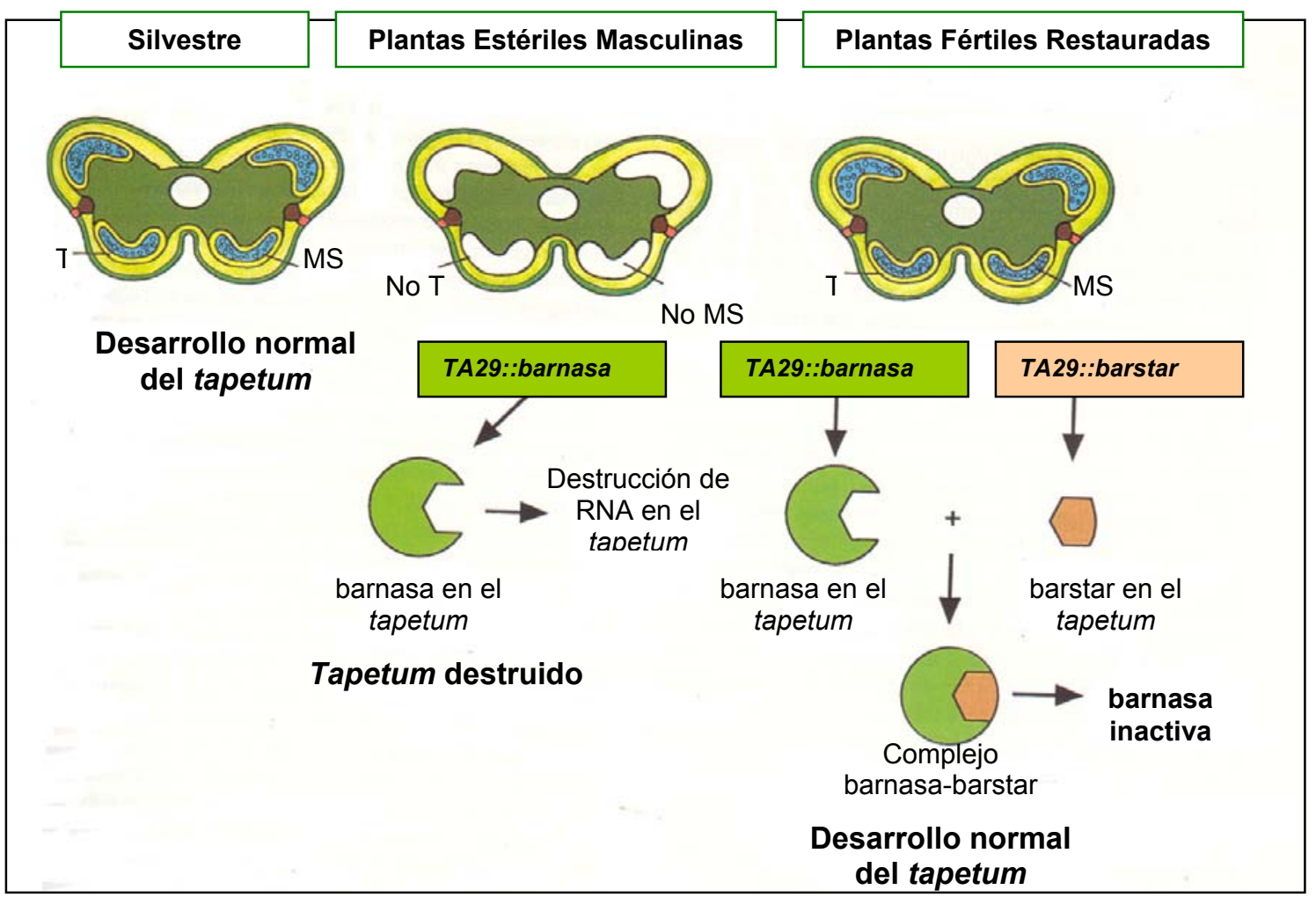

Figura 11. Representación esquemática de los experimentos de obtención de esterilidad masculina y restauración de la fertilidad descritos por Mariani et al. (1990; 1992). MS, microsporas; T, tapetum. (Esquema tomado de Goldberg et al. (1993).

Los laboratorios de C. Mariani en colaboración con Plant Genetic System (Gent, Bélgica) han desarrollado el uso del sistema TA29::barnasa/TA29::barstar para la producción de plantas androestériles en toda una variedad de cultivos que incluye por ejemplo la colza, el tomate, la lechuga y el maíz (Mariani et al., 1992).

\section{PARTENOCARPIA EN TOMATE}

El desarrollo del fruto de tomate se desencadena después de los procesos de polinización y fertilización. Estos procesos, y en particular la producción de polen viable, dependen de estrechas condiciones ambientales. Los cultivares de tomate solo producen frutos con semillas de forma consistente cuando se cultivan dentro de un rango de temperaturas nocturnas entre 15 y $21^{\circ} \mathrm{C}$ y diurnas entre 30 y $35^{\circ} \mathrm{C}$ (George et al., 1984). La partenocarpia genética ofrece un método alternativo a la producción de frutos de tomate bajo condiciones de temperatura adversas de las que dependen los procesos de polinización y fertilización (George et al., 1984).

El término partenocarpia define el fenómeno de la formación de frutos sin semillas, bien por la ausencia de polinización, o porque se produce polinización pero no fertilización, o porque se producen ambos fenómenos pero las semillas abortan antes de llegar a la 
madurez (Gillaspary et al., 1993). La partenocarpia en el tomate se puede producir naturalmente o ser inducida artificialmente. La partenocarpia natural se produce por causas genéticas y puede ser obligatoria o facultativa. La partenocarpia facultativa es aquella que sólo se obtiene en determinadas condiciones ambientales (Ho y Hewitt, 1986). La partenocarpia también se puede inducir artificialmente por la aplicación de hormonas en el ovario, principalmente auxinas y giberelinas (GAs) (Goodwing, 1978; Schwabe y Mills, 1981).

En tomate, se han identificado varios cultivares con fuentes naturales de partenocarpia. Soressi (1970) encontró un mutante de anteras cortas (sha-pat) tras el tratamiento de semillas con EMS, que producía frutos partenocárpicos. Independientemente, Pecaut y Philouze (1978) descubrieron un mutante espontáneo denominado "Montfavet 191", proveniente del cruce entre el cv. Santa Cruz Samano (Brasil) y una línea de cultivos de Montfavet, Francia, que presentaba un fenotipo similar al encontrado en el mutante shapat. El cultivar ruso "Severianín" se desarrolló a partir de un cruce ínter específico entre $L$. esculentum y L. hirsutum (Philouze, 1983). Este cultivar es una fuente de partenocarpia facultativa que tiene la capacidad de desarrollar frutos sin semillas en ausencia de polen viable, tanto bajo condiciones de baja temperatura como en condiciones de alta temperatura (Philouze y Maisonneuve, 1978a).

La partenocarpia en el mutante sha-pat, al igual que la del cultivar "Montfavet 191", está controlada por un único gen recesivo denominado pat (Soressi y Salami, 1975; Pecaut y Philouze, 1978). A partir de estudios de segregación de la partenocarpia en las progenies derivadas de cruces entre el cv. "Severianín" y genotipos no partenocárpicos, diversos autores han concluido que la partenocarpia en este cultivar está controlada por un gen recesivo, denominado pat-2 (Philouze y Maisonneuve, 1978b; Lin et al., 1984; Nuez et al., 1996; Catalá et al., 1990). Se ha demostrado a través del cruce entre el cv. "Severianín" y "Montfavet 191" que pat y pat-2 son genes no alélicos (Philouze y Maisonneuve, 1978b).

De manera similar, se han identificado otros genes recesivos no alélicos causantes de la partenocarpia en diversos cultivares de tomate. Por ejemplo, el sistema genético pat3/pat-4 es el responsable de la partenocarpia natural de la línea alemana "75/79" y el gen pat-5 es el responsable de la partenocarpia de la línea "Sub Artic Plenty" de Canadá (Nuez et al., 1996).

Con frecuencia, la partenocarpia en tomate no interfiere con otros procesos del desarrollo generativo. Como sucede en la variedad "Severianín" y en frutos partenocárpicos inducidos por giberelinas o auxinas, la morfología de los óvulos y la producción de gametos es con frecuencia normal (Lin et al., 1983; Ashaira et al., 1967). Sin embargo, la mutación pat causa un síndrome complejo que afecta diferentes aspectos del desarrollo de flores y frutos. Este mutación recesiva afecta a los estambres (tamaño 
reducido y transformación a órganos carpeloides), a los óvulos (crecimiento del integumento detenido e inviabilidad) y al desarrollo del ovario (crecimiento autónomo o partenocarpia) (Mazzucato et al., 1998). En los lóbulos de las anteras pat con fenotipos más severos de malformación, la hipertrofia del tapetum produce la degeneración del tejido esporofítico y esto inhibe la producción de granos de polen (Mazzucato et al., 1998). Uno de los rasgos más notables del fenotipo los mutantes pat consiste en los defectos en las anteras y los óvulos.

A partir de estas observaciones se ha planteado una hipótesis que postula que la partenocarpia podría ser un efecto secundario inducido como consecuencia de estas malformaciones en los órganos reproductivos (Mazzucato et al., 1999). Se ha observado que el número de semillas producidas por fruto en el mutante pat es inversamente proporcional a la severidad del fenotipo de malformación de estambres y carpelo. Se ha mostrado que uno de los factores que influyen en la carencia de semillas en el mutante pat es el fenotipo aberrante de las anteras que dificulta la deposición del polen en el estigma (Mazzucato et al., 1999). Posteriormente, Mazzucato et al. (2003) propusieron que ésta no sería la única razón para la ausencia de semillas en los frutos pat, ya que la polinización manual no logra restaurar la producción de frutos con semillas en ovarios que presentan una fracción de óvulos morfológicamente normales. Consideraron que posiblemente también pudiesen existir otros defectos en el proceso reproductor del mutante $\mathrm{y}$, de acuerdo con eso, consiguieron demostrar que en ese genotipo la partenocarpia estaba relacionada con anormalidades en la interacción entre el tubo polínico y el ovario.

Se ha sugerido que la partenocarpia natural está relacionada con la producción de una concentración de reguladores de crecimiento en el ovario superior a la concentración umbral en ausencia de polinización (Nitsh, 1970). El alto contenido de hormonas endógeno sería la señal que induciría el proceso de desarrollo y crecimiento del ovario para dar lugar a un fruto de tamaño y aspecto similar al que se formaría si la flor hubiese sido polinizada (Fos, 1993). Esta hipótesis se basa en datos que muestran una correlación entre el desarrollo partenocárpico y el incremento en los niveles de auxinas y giberelinas en el fruto antes de la fecundación (Gillaspary et al., 1993). Considerando los defectos en la elongación celular de diferentes órganos del mutante pat (anteras cortas, integumento del óvulo no desarrollado y frutos y semillas de pequeño tamaño), se ha propuesto que las funciones PAT interaccionan con la ruta metabólica de GAs. Las aplicaciones de $\mathrm{GA}_{3}$ revirtieron el fenotipo de las anteras pat al fenotipo silvestre, aunque no ocurrió lo mismo con la fertilidad femenina (Mapelli et al., 1979). Las aplicaciones de $\mathrm{GA}_{3}$ también revirtieron la morfología floral y la fertilidad en el mutante estéril masculino de tomate stamenless-2 a niveles similares a los de las plantas silvestres (Sawhney y Greyson, 1973). Fos et al. 
(2000) han puesto de manifiesto que la aplicación del inhibidor de la biosíntesis de GAs paclobutrazol a ovarios no polinizados de la línea partenocárpica MApat-2 inhibe el crecimiento del fruto y este efecto se revierte completamente con la aplicación de $\mathrm{GA}_{3}$. Además, han encontrado alteraciones muy marcadas en los niveles de GAs en los ovarios de líneas partenocárpicas de tomate (MA/pat-2 y CU/pat-2) respecto a sus correspondientes líneas cuasiisogénicas no partenocárpicas (MA/wt y CU/wt). Por último, se han usado técnicas de "differential display" para comparar la expresión de genes en ovarios de tomate entre una línea normal y su línea cuasiisogénica homocigota para la mutación pat (Testa et al., 2002). De esta manera, se han identificado genes transcritos diferencialmente durante la expresión de partenocarpia y/o los primeros estadios del desarrollo del fruto en estos mutantes. Uno de ellos fue el GAD3, anteriormente descrito como un gen de respuesta a GAs (Jacobsen y Olszewski, 1996). El gen GAD3 codifica para una deshidrogenasa de cadena corta y existen evidencias que demuestran que estas enzimas pertenecen a una familia con funciones en las vías de desarrollo controladas por hormonas, y en particular por las GAs (Testa et al., 2002).

\subsection{Relación entre los genes homeóticos florales y la partenocarpia en tomate}

Se ha mencionado anteriormente que la mayoría de los genes que controlan la identidad de los órganos florales codifican factores transcripcionales pertenecientes a la familia MADS-box y que las proteínas de esta familia se caracterizan por la presencia de un dominio altamente conservado en el extremo N-terminal, la caja MADS; este hecho ha sido usado para aislar genes MADS-box en diversas especies .

En tomate se han aislado y caracterizado varios genes MADS-box de expresión específica en flores (Pnueli et al., 1991; 1994; Ampomah-Dwamena et al., 2002). La función de alguno de ellos ha sido investigada por técnicas de cosupresión y expresión antisentido en plantas transgénicas. El gen MADS-box de tomate TM29 presenta homología de secuencia con los genes SEP de Arabidopsis. Su expresión se observa uniformemente en el meristemo floral en aquellas células que darán lugar a los cuatro primordios florales (Ampomah-Dwamena et al., 2002). Posteriormente, una vez diferenciados los primordios de órganos florales, la expresión de TM29 desaparece de los órganos del perianto y se restringe a los órganos reproductores (estambres y carpelo). Las plantas transgénicas que expresaban este gen en orientación antisentido mostraron conversiones homeóticas de pétalos y estambres a sépalo, fenotipo similar al que presenta el triple mutante sep1 sep2 sep3 y el doble mutante de pistillata y agamous (ap3 ag, pi ag) (Pelaz et al., 2000). La regulación negativa de este gen afectó la fertilidad 
masculina y femenina y produjo el desarrollo partenocárpico del fruto (AmpomahDwamena et al., 2002).

El gen MADS-box de tomate TM5, homólogo al gen SEP3 de Arabidopsis, se expresa en los primordios de pétalos, estambres y carpelo de las flores de tomate (Pnueli et al., 1991). En los estambres, el transcrito de TM5 se detectó en las células arquesporiales y posteriormente en las células esporógenas. En el carpelo, el mRNA de TM5 se detectó en los óvulos. Los estambres de las plantas transgénicas donde se inhibía la expresión de este gen no formaban el típico cono estaminal alrededor del estilo. Éstos estaban separados y ocupaban las posiciones de los pétalos y los sépalos. En el interior de las anteras, los sacos polínicos estaban colapsados y no desarrollaron granos de polen. La fertilidad femenina también se vio afectada. Además, las flores transgénicas desarrollaron frecuentemente frutos partenocárpicos (Pnueli et al., 1994).

Otro gen de tomate homólogo a los genes SEP, el gen TM8, se expresa en estadios tempranos del desarrollo de pétalos, estambres y carpelos (Pnueli et al., 1991). Su expresión antisentido, aparte de producir alteraciones morfológicas y cambios de identidad en los órganos florales, esterilidad masculina y femenina de las plantas, también provocó el desarrollo de frutos partenocárpicos (Lifschitz et al., 1993).

El mutante de tomate stamenless ha sido caracterizado en detalle recientemente y se ha mostrado que en sus flores los pétalos se convierten parcialmente en sépalos y que los estambres se fusionan al carpelo. Independientemente de mostrar conversiones homeóticas similares a las que presentan los mutantes def y glo en Antirrhinum y ap3 y pi en Arabidopsis, se ha observado que los frutos formados por este mutante carecen de semillas (Gómez et al., 1999).

La asociación de transformaciones homeóticas con el desarrollo de frutos partenocárpicos no se ha observado sólo en tomate. Así, la mutación del gen de manzano $\mathrm{MdPI}$, homólogo al gen $\mathrm{PI}$ de Arabidopsis, provocó la transformación de pétalos en sépalos y de estambres en carpelos y además la producción de frutos partenocárpicos (Yao et al., 2001). Todos estos ejemplos han llevado a sugerir la posibilidad de que en estas especies los genes que intervienen en la identidad y desarrollo de los órganos florales también, puedan tener otras funciones que afecten a procesos posteriores tales como el desarrollo autónomo del ovario (Mazzucato et al., 1998). 


\section{ANTECEDENTES}

En el grupo de trabajo en el que se ha desarrollado este trabajo, se estudian los procesos de iniciación y desarrollo floral en plantas. Se ha realizado la caracterización morfológica de mutantes homeóticos de guisante con fenotipos que sugieren la pérdida de las funciones $A$, B y C (Beltrán et al., 1996; Ferrándiz, 1996; Ferrándiz et al., 1999) y se han identificado y caracterizado molecularmente una colección de genes responsables del control de la identidad de los órganos florales (de la familia de genes MADS-box) en guisante (Ferrándiz, 1996; Navarro, 2001). La caracterización de dichos genes se ha ampliado con el estudio de sus funciones mediante el análisis de los fenotipos resultantes de la expresión constitutiva de los mismos en plantas transgénicas de Arabidopsis thaliana y Nicotiana tabacum (Berbel et al., 2001; Berbel, 2002).

Para identificar genes específicos de órganos florales no pertenecientes a la familia MADS-box, aunque sí implicados en el proceso de desarrollo floral, se generaron anticuerpos monoclonales contra proteínas específicas de cada órgano floral (Cañas et al., 2002). Uno de estos anticuerpos monoclonales (A1, específico de estambre) se utilizó como herramienta para aislar la proteína que reconoce y el correspondiente gen que la codifica. Este anticuerpo reconoció una proteína, END1, abundante en los extractos proteicos de este órgano floral. La inmunolocalización de esta proteína indicó su acumulación en los tejidos que conforman las paredes que rodean los sacos polínicos de la antera (Gómez, 2000; Gómez et al., 2004). La secuencia del extremo N-terminal de END1 mostró alta homología con la proteína PA2 de guisante, y la utilización del cDNA completo del gen PA2 como sonda en el rastreo de una genoteca de cDNA de flores de guisante hizo posible el aislamiento del cDNA de END1. La caracterización del gen END1 mostró que su expresión comienza cuando el primordio estaminal inicia su desarrollo para convertirse en estambre y continúa hasta que se produce la dehiscencia de la antera. Durante este período, el mRNA de END1 se detecta en las líneas celulares que darán lugar a la epidermis, el endotecio, la capa intermedia y el tejido conectivo de la antera, así como en estos tejidos una vez desarrollados (Gómez, 2000; Gómez et al., 2004).

Por otra parte, se aisló la región promotora de este gen. Mediante el análisis informático de su secuencia 5' se encontraron, entre otras, diversas secuencias con homología a elementos reguladores presentes en otros promotores de expresión específica en anteras y dos posibles cajas CArG (Gómez, 2000; Gómez et al., 2004). Las cajas CArG son elementos reguladores a los que se unen los factores de transcripción de tipo MADS-box. La presencia de estas cajas CArG en la región 5' del gen END1 sugirió que éste podría ser un gen diana de los genes MADS-box de guisante que especifican la identidad del estambre. Se comprobó además que dos fragmentos de la región 5',-2736/-6 y -1531/-6, de 
la secuencia genómica de END1 eran capaces de dirigir la expresión específica del gen informador GUS a las anteras de plantas de especies diferentes a guisante: Arabidopsis thaliana, Nicotiana tabacum y Lycopersicon esculentum. La expresión de GUS en las anteras de las plantas transgénicas de estas especies es similar a la del gen END1 en las anteras de guisante (Gómez, 2000; Gómez et al., 2004).

\section{OBJETIVOS}

Los procesos reproductores en las angiospermas tienen lugar en dos órganos florales especializados: la antera y el pistilo. En ellos se forman los gametofitos masculinos y femeninos, respectivamente, que son los responsables de llevar a cabo la fertilización.

Se han aislado y caracterizado molecularmente genes activos en diferentes tipos celulares durante la diferenciación y el desarrollo de la antera. La caracterización de dichos genes ha ayudado a comprender la función de los tejidos de la antera durante la gametogénesis y este conocimiento ha proporcionado las bases para desarrollar estrategias moleculares que permitan la obtención de plantas androestériles para la producción comercial de semillas híbridas.

Se han usado promotores específicos de antera, especialmente de tapetum y polen, para dirigir la expresión de genes citotóxicos a la antera y provocar la degeneración de tejidos que impida el desarrollo de los granos de polen (Mariani et al., 1990; De Bolck et al., 1997; Lee et al., 2003).

La especificidad que confiere el promotor de END1 a la expresión del gen GUS en las anteras de otras plantas distintas del guisante, sugirió que podría utilizarse como una herramienta biotecnológica eficaz para la obtención de plantas androestériles empleándolo para dirigir la expresión de genes citotóxicos en las anteras.

En este trabajo, nos planteamos comprobar esta posibilidad. Para ello, se transformaron dos plantas modelo, Arabidopsis y tabaco, y una planta de interés agronómico, el tomate. En la construcción genética utilizada para la transformación el promotor de END1 se halla fusionado transcripcionalmente a la barnasa, un gen citotóxico previamente utilizado en ensayos de ablación celular específica en plantas.

Por otra parte, en el caso particular del tomate, los resultados previos de otros laboratorios sugieren que podría existir una relación entre la androesterilidad y el desarrollo autónomo del ovario en esta especie. Por ello, las plantas androestériles de tomate se han utilizado para analizar esta posible relación.

Por último, para obtener información sobre los elementos reguladores en cis que determinan la expresión celular específica y temporal de END1, se ha realizado un análisis funcional del promotor de este gen. 
Los objetivos concretos de este trabajo han sido:

PRIMERO.- Evaluar el potencial del promotor de END1 para desarrollar una herramienta biotecnológica encaminada a la obtención de plantas transgénicas androestériles de Arabidopsis, tabaco y tomate.

SEGUNDO.- Comprobar si en tomate los defectos en las anteras que conducen a la androesterilidad, condicionan el desarrollo autónomo del ovario a fruto.

TERCERO.- Definir los elementos reguladores en cis involucrados en la regulación de la expresión del gen END1. Analizar la funcionalidad in vivo de las posibles cajas CArG encontradas en la región 5' de END1. 
MATERIALES Y MÉTODOS 



\section{MATERIAL BIOLÓGICO}

\subsection{MATERIAL VEGETAL}

En la tabla 2 se muestran las distintas plantas utilizadas en este trabajo.

Tabla 2. Plantas utilizadas en este trabajo y su uso.

\begin{tabular}{|c|c|c|c|}
\hline Planta & Variedad /ecotipo & \multicolumn{2}{|l|}{ Uso } \\
\hline \multirow[t]{3}{*}{ Arabidopsis thaliana } & \multirow[t]{3}{*}{ Columbia (Col) } & $\begin{array}{l}\text { Expresión del } \\
\text { END1::barnasa }\end{array}$ & transgén \\
\hline & & $\begin{array}{l}\text { Expresión del } \\
\text { END1::barstar. }\end{array}$ & transgén \\
\hline & & $\begin{array}{l}\text { Expresión de las } \\
\text { construcciones del } \\
\text { de END1 con } \\
\text { deleciones. }\end{array}$ & $\begin{array}{r}\text { diferentes } \\
\text { promotor } \\
\text { diferentes }\end{array}$ \\
\hline Nicotiana tabacum & cv. Petite Havana SR1 & $\begin{array}{l}\text { Expresión del } \\
\text { END1::barnasa }\end{array}$ & transgén \\
\hline Lycopersicon esculentum & cv. Micro-Tom & $\begin{array}{l}\text { Expresión del } \\
\text { END1::barnasa }\end{array}$ & transgén \\
\hline
\end{tabular}

Las muestras de los tejidos vegetales utilizadas en este trabajo para la extracción de ácidos nucleicos se recogieron directamente de la planta, se congelaron en nitrógeno líquido y se almacenaron a $-80^{\circ} \mathrm{C}$ hasta su posterior utilización. Las muestras destinadas a estudios de microscopia se fijaron para ser procesadas posteriormente según se explica en el apartado 2.

\subsubsection{CONDICIONES DE CULTIVO DE LAS PLANTAS}

\subsubsection{Cultivo de Arabidopsis thaliana en alvéolos y macetas}

Las plantas de Arabidopsis se cultivaron en fitotrones bajo condiciones de crecimiento controladas de fotoperiodo y temperatura. La temperatura fue de $21^{\circ} \mathrm{C}$ y la iluminación procedía de tubos fluorescentes de luz blanca fría con una intensidad de $150 \mu \mathrm{E} \mathrm{m} \mathrm{m}^{-2} \mathrm{~s}^{-2}$ (Sylvania Standard F58W/133-T8). Las plantas se cultivaron bajo condiciones de fotoperiodo inductivo, que eran $16 \mathrm{~h}$ de luz y $8 \mathrm{~h}$ de oscuridad (día largo, DL) y de fotoperiodo no inductivo que fueron $8 \mathrm{~h}$ de luz y $16 \mathrm{~h}$ de oscuridad (día corto, DC).

Las semillas fueron sembradas en alvéolos o en macetas dependiendo del posterior uso de las plantas generadas. Las semillas se sembraron en alvéolos de plástico de $6,5 \times 6,5 \times 5 \mathrm{~cm}$ 
para cultivos de día largo o día corto en una mezcla de turba: perlita: vermiculita (1:1:1). Se colocaron en bandejas dentro de cámaras de cultivo y se regaron por inmersión con solución de Hoagland $n^{\circ} 1$ suplementada con oligoelementos (Hewitt, 1966) Tras la siembra, las bandejas se cubrieron con plástico para mantener la humedad y evitar contaminaciones con otras semillas procedentes de plantas próximas. Se mantuvieron en oscuridad a $4{ }^{\circ} \mathrm{C}$ durante 3 días a fin de sincronizar la germinación y al cabo de esos días se pasaron a cabinas.

Al aparecer el primer par de hojas aproximadamente o ver condensación en el plástico que las recubría, se agujereó el mismo en distintos puntos de la bandeja que fueron incrementándose hasta que se eliminó el plástico por completo al cabo de tres días.

La siembra en macetas se llevó a cabo en macetas de plástico de $11 \mathrm{~cm}$ de diámetro, para cultivos de DL o DC y se realizó el mismo proceso que para la siembra en alvéolos.

\subsubsection{Cultivo de Arabidopsis thaliana en cajas Petri}

El cultivo in vitro de Arabidopsis en cajas Petri, se realizó en cabinas con temperatura constante de $25{ }^{\circ} \mathrm{C}$ bajo condiciones de día largo (DL). La luz fue suministrada por tubos fluorescentes de tipo Grolux $36 \mathrm{~W}$ (Sylvania) con una intensidad de $90 \mu \mathrm{E} \mathrm{m} \mathrm{m}^{-2} \mathrm{~s}^{-2}$.

Las semillas se esterilizaron por inmersión durante $3 \mathrm{~min}$ en etanol $70 \%(\mathrm{v} / \mathrm{v})$ y $0,005 \%$ Tritón X-100. Durante este tiempo se mezclaron con la solución anterior moviendo el tubo que las contenía. Posteriormente se eliminó la solución y se añadió etanol $96 \%$ agitando durante 1 minuto. Inmediatamente después se dejaron caer las semillas con el etanol en papel de filtro estéril hasta que se secaron. Para la selección de transformantes primarios las semillas esterilizadas (30 $\mathrm{mg}$ de semillas aproximadamente) se repartieron uniformemente en placas Petri de $15 \mathrm{~cm}$ de diámetro que contenían medio de selección con kanamicina [2,2 g/l de sales MS (Duchefa), $20 \mathrm{~g} / \mathrm{l}$ sacarosa, 0,1 g/l MES pH 5,9, 0,6\% agar (Pronadisa), $50 \mathrm{mg} / \mathrm{l}$ kanamicina, $300 \mathrm{mg} / \mathrm{l}$ timentina]. Las cajas con las semillas se almacenaron durante tres días a $4{ }^{\circ} \mathrm{C}$ en oscuridad tras los cuales se trasladaron a una cabina de cultivo in vitro. Al cabo de 7-10 días de la siembra de los transformantes que se distinguían por su color verde y raíz elongada, se transplantaron con ayuda de pinzas a alvéolos de plástico como se describe en el apartado 1.1.1.1.

\subsubsection{Cultivo de Nicotiana tabacum en macetas}

Las plantas de tabaco provenientes del cultivo in vitro se cultivaron individualmente en macetas de plástico de $13 \mathrm{~cm}$ de diámetro que contenían una mezcla de turba:vermiculita (1:1) previamente esterilizada, en una cabina de invernadero bajo condiciones controladas y con una temperatura de $24{ }^{\circ} \mathrm{C}$ durante el día y $18{ }^{\circ} \mathrm{C}$ durante la noche. La luz natural se 
suplementó con luz artificial mediante lámparas de vapor de mercurio de $400 \mathrm{~W}$ [Phillips HDK/ $400 \mathrm{HPI} \circledast, \mathrm{N}$ ], para mantener un fotoperiodo de día largo. El riego consistió en solución de Hoagland $\mathrm{n}^{\circ} 1$ aportada mediante un sistema de riego por goteo automatizado durante 2 min, 4 veces al día.

\subsubsection{Cultivo de Nicotiana tabacum en cajas de Petri}

El cultivo in vitro de tabaco se realizó en cabinas con temperatura constante de $25^{\circ} \mathrm{C}$, bajo condiciones de fotoperiodo de día largo (16 h de luz y $8 \mathrm{~h}$ de oscuridad), con una intensidad de luz de $90 \mu \mathrm{E} \mathrm{m} \mathrm{m}^{-2} \mathrm{~s}^{-2}$ suministrada por tubos fluorescentes de luz tipo Grolux 36W (Sylvania).

Las plantas resistentes a kanamicina (transformantes primarios) cuyo cultivo se había iniciado en cajas de Petri, fueron posteriormente transplantadas a alvéolos de plástico de 6'5 x 6’5 x $5 \mathrm{~cm}$ con una mezcla de turba:vermiculita (1:1). Estos cultivos permanecieron cubiertos con un plástico transparente, en el que progresivamente se fueron haciendo agujeros a fin de evitar una excesiva condensación de agua durante 9 días. Tras el período de aclimatación, las plántulas se transplantaron a macetas individuales, donde se cultivaron en cabinas de invernadero bajo condiciones controladas de temperatura y fotoperiodo como se describe en el apartado 1.1.1.3.

\subsubsection{Cultivo de Lycopersicon esculentum en frascos de cristal}

El cultivo de tomate en frascos de cristal se llevó a cabo para sembrar semillas de la variedad de tomate Micro-Tom, con el objetivo obtener los cotiledones que servirían como explantes para la transformación. Se llevó a cabo en cabinas con temperatura constante de $25^{\circ} \mathrm{C}$, bajo condiciones de fotoperiodo de día largo (16 h de luz y $8 \mathrm{~h}$ de oscuridad), con una intensidad de luz de $90 \mu \mathrm{E} \mathrm{m} \mathrm{m}^{-2} \mathrm{~s}^{-2}$ suministrada por tubos fluorescentes de luz tipo Grolux 36W (Sylvania).

Las semillas de tomate se pusieron en bolsitas de malla dentro de un frasco de cristal de 9 $\mathrm{cm}$ de diámetro y $10 \mathrm{~cm}$ de altura, que contenía etanol $70 \%$, durante 1 min y 30 seg manteniendo constante la agitación. Luego se pasaron a una solución de lejía a $30 \mathrm{~g} / \mathrm{l}$ (a partir de lejía comercial a $40 \mathrm{~g} \mathrm{Cl}_{2} / \mathrm{l}$ tomando $75 \mathrm{ml}$ de la misma y llevándolo a $100 \mathrm{ml}$ con agua estéril) que contenía además 0'02 \% de Tween 20 (SIGMA) para ayudar a romper la tensión superficial entre los tejidos, mejorando el contacto entre el tejido y el agente desinfectante. A continuación, se eliminó la solución desinfectante y se hicieron 4 lavados sucesivos con agua destilada estéril $(5,10,15,20$ minutos respectivamente). Por último, se eliminó el agua y se dejaron las bolsitas con semillas dentro del mismo recipiente. 
Tras la desinfección de las semillas, se abrieron las bolsitas que las contenían con unas pinzas estériles, y se tomaron una por una para ser depositadas sobre la superficie del medio de germinación que estaba contenido en un bote de cristal de $9 \mathrm{~cm}$ de diámetro y $10 \mathrm{~cm}$ de altura. La composición del medio de germinación era de $15 \mathrm{~g} / \mathrm{l}$ de sacarosa, 2 '2 g de sales MS (DUCHEFA), 0'1 g/l de MES pH 5'9, $3 \mathrm{~g} / \mathrm{l}$ de agar.

\subsubsection{Cultivo de Lycopersicon esculentum en macetas}

Las plantas de tomate provenientes del cultivo in vitro se extrajeron del frasco y se lavaron las raíces para eliminar restos de agar procurando no dañarlas. A continuación se transplantaron en macetas de la misma manera que se hizo para plantas de tabaco.

\subsubsection{POLINIZACIÓN CRUZADA}

La polinización cruzada se realizó en plantas estériles masculinas de Arabidopsis, tabaco y tomate con objeto de mantener las líneas que por si mismas no podían reproducirse al ser androestériles.

En el caso del experimento de restauración de la fertilidad se utilizó la polinización cruzada para obtener plantas que expresasen los genes barnasa y barstar.

El procedimiento consistió en aplicar directamente el polen de la flor donadora (estadio en que las anteras están dehiscentes) sobre el estigma del carpelo de la flor receptora (madre).

En el caso de las plantas END1::barnasa de Arabidopsis, la planta TAB 1 de tabaco y aquellas de fenotipo severo de malformación en las anteras de tomate, no fue necesario emascular la flor receptora antes de la antesis por la esterilidad masculina que estas presentaban.

No sucedió así para la planta TAB 2 de tabaco y las de fenotipo medio y leve de malformación de las anteras de tomate, a las que fue necesario emascular antes de la polinización. 


\subsection{MICROORGANISMOS}

\subsubsection{CEPAS BACTERIANAS}

En este trabajo se han utilizado las cepas bacterianas que se detallan en la tabla 3.

Tabla 3. Cepas bacterianas utilizadas en este trabajo.

\begin{tabular}{l|l|l}
\hline Cepa & Referencia / origen & Uso \\
\hline $\begin{array}{l}\text { DH5a (E.coli) } \\
\begin{array}{l}\text { C58 pMP90 }(A . \\
\text { tumefaciens })\end{array}\end{array}$ & Hanahan (1983) & Transformación de bacterias \\
$\begin{array}{l}\text { LBA4404 }(A . \\
\text { tumefaciens) }\end{array}$ & Hoekema et al (1983). & Transformación de plantas \\
\hline
\end{tabular}

\subsubsection{CONDICIONES DE CULTIVO DE MICROORGANISMOS}

Los cultivos líquidos de bacterias de $E$. coli y $A$. tumefaciens se incubaron durante toda la noche a $37^{\circ} \mathrm{C}$ y $28^{\circ} \mathrm{C}$ respectivamente con agitación de $200 \mathrm{rpm}$. Los cultivos de E. coli y $A$. tumefaciens en cajas con medio sólido se incubaron toda la noche en estufa a $37^{\circ} \mathrm{C}$ y tres días a $28^{\circ} \mathrm{C}$ respectivamente.

\subsubsection{Medio de cultivo de microorganismos}

El medio utilizado para el crecimiento de los microorganismos fue:

- Medio LB (medio Luria-Bertani): 1\% triptona, 0'5\% extracto de levadura, 1\% $\mathrm{NaCl}, \mathrm{pH} 7{ }^{\prime} 0$. Cuando se utilizó el medio sólido, éste se solidificaba mediante la adición de 1'5\% de agar (Pronadisa).

\section{PREPARACIÓN DE MUESTRAS VEgETALES PARA MICROSCOPÍA ÓPTICA Y MICROSCOPÍA ELECTRÓNICA DE BARRIDO (SEM)}

\subsection{Fijación}

Las muestras vegetales se introdujeron en p-formaldehído al $4 \%(\mathrm{p} / \mathrm{v})$ en 1 XPBS $\mathrm{pH} 7{ }^{\prime} 0$ inmediatamente después de su recolección. Posteriormente, fueron sometidas a dos o tres pulsos de vacío de 3 min cada uno, se les cambió la solución fijadora por una fresca y se mantuvieron en ella durante toda la noche a $4{ }^{\circ} \mathrm{C}$. Tras el proceso de fijación de los tejidos se lavaron con 1XPBS y se deshidrataron hasta etanol absoluto mediante una serie de lavados 
sucesivos de 30 min a $4{ }^{\circ} \mathrm{C}$ en soluciones crecientes de etanol $(15 \%, 30 \%, 50 \%, 70 \%, 85 \%$, $96 \%, 100 \%)$. A partir de este punto, las muestras sufrieron un proceso distinto en función si fueron incluidas en parafina (Paraplast Plus, Sigma), resina (Historesin, Leica) o usadas para ser analizadas por microscopía electrónica de barrido (SEM).

\subsection{Inclusión en parafina}

Las muestras se introdujeron en soluciones crecientes de Histo-Clear en etanol (25\%, 50\%, $100 \%$ de Histo-Clear) y posteriormente se incluyeron gradualmente en series crecientes de parafina en Histo-Clear a $58{ }^{\circ} \mathrm{C}$ hasta llegar a parafina absoluta. Tras dos días en parafina absoluta en los cuales se iban haciendo cambios a parafina fresca, las muestras se colocaron en moldes adecuados para seccionarlas. Se mantuvieron a $4{ }^{\circ} \mathrm{C}$ hasta su utilización.

\subsection{Inclusión en resina}

Las muestras fijadas se incluyeron gradualmente en resina a través de series de etanol:resina $(2: 1,1: 1,1: 2)$ hasta resina absoluta. Tras dos días en resina pura las muestras se colocaron en cápsulas de gelatina y se activó la polimerización de la resina de acuerdo a las instrucciones del fabricante.

\subsection{Procesamiento de las muestras incluidas en parafina o resina}

Las muestras incluidas en parafina o resina se seccionaron en un microtomo rotatorio Microm (secciones de 7-10 $\mu \mathrm{m}$ de de grosor) o en un ultramicrotomo Ultracut $\mathrm{E}$ (secciones de $2 \mu \mathrm{m}$ ) respectivamente. Los cortes obtenidos por ambas técnicas se depositaron sobre portaobjetos tratados con TESPA (Sigma) como adherente (Rentrop et al., 1986).

Las secciones de tejidos incluidos en parafina una vez sobre los portas, se desparafinaron en Histo-Clear durante $10 \mathrm{~min}$, y luego se rehidrataron en soluciones decrecientes de etanol/agua $(100 \%, 70 \%, 50 \%)$, durante 1 min cada y finalmente se lavaron con agua destilada.

Posteriormente se tiñeron con safranina o $1 \%(\mathrm{p} / \mathrm{v})$ en etanol $96 \%$ diluida con agua $1: 1$ antes de usar. El proceso de teñido con safranina duró de 2-24 horas tras las cuales se procedió a lavar las muestras con agua y se añadió ácido acético que se lavó nuevamente con agua para pasar a la tinción con una solución de Azul Alcián 1\% $(\mathrm{p} / \mathrm{v})$ en ácido acético diluido en agua al $3 \%(\mathrm{v} / \mathrm{v})$ durante $2 \mathrm{~min}$. Transcurrido ese tiempo se lavaron las muestras con agua y se dejaron secar para montarse permanentemente con Merckoglas (Merck). Las secciones de tejidos incluidos en resina, se tiñeron con Azul de Toloudina 0'02\% (p/v) en 
agua, durante $5 \mathrm{~min}$, tras los cuales se lavó el colorante sobre los portas con agua y se dejaron secar para montarse permanentemente con Merckoglas (Merck).

Las observaciones y fotografías se realizaron con un microscopio óptico Eclipse 600 (Nikon).

\subsection{Punto crítico y análisis de las muestras}

Las muestras almacenadas en etanol del $100 \%$, se desecaron con $\mathrm{CO}_{2}$ líquido en un aparato secador de punto crítico Polaron E300, se montaron en portaobjetos metálicos con cinta adhesiva de carbono activado sobre los que fueron orientadas y diseccionados convenientemente. Después del montaje, las muestras fueron recubiertas con un sombreado de partículas de oro-paladio de 200 nm, en atmósfera de argón ionizado en un Sputter Coater SCD005 (BALTEC).

Las imágenes se obtuvieron mediante el programa Autobeam de la plataforma ISIS (Oxford Instruments), con una velocidad de barrido de 200 s por imagen, en un microscopio electrónico de barrido JEOL JSM-5410 operando bajo las condiciones de microanálisis de $10 \mathrm{kV}$ y distancia de trabajo de $25 \mathrm{~mm}$.

\section{MANIPULACIÓN DE ÁCIDOS NUCLÉICOS}

\subsection{Clonación}

Las clonaciones se hicieron en diferentes plásmidos en función de la procedencia de los fragmentos de DNA y de los fines requeridos.

1. Los productos de PCR se clonaron en el plásmido pGEM-T Easy (Promega), que contiene un sitio de clonación específico para productos de PCR con una adenina libre en los extremos 3'.

2. El plásmido pBl101 fue empleado para la obtención de plantas transgénicas de Arabidopsis, tabaco y tomate mediante la transformación con Agrobacterium tumefaciens (apartado 7). Este plásmido contiene el gen nptll que ofrece resistencia a la kanamicina y el gen de la $\beta$-glucuronidasa que permitió realizar análisis histoquímico de las plantas transformadas. El plásmido pBI101 se utilizó para realizar el análisis funcional del promotor de END1 en Arabidopsis y para llevar a cabo la expresión del transgén END1::barnasa en las tres plantas citadas y del END1::barstar en A.thaliana. 


\subsection{Reacciones enzimáticas}

\subsubsection{Reacciones de ligación}

Las reacciones de ligación se realizaron manteniendo una proporción molar entre vector e inserto de 1:2 en el caso del plásmido pGEM-T Easy (Promega) y de 1:5 en el caso del vector pBI101. El volumen final de las reacciones fue de 10 o $20 \mu \mathrm{l}$. Este volumen incluía el volumen de vector/inserto, 1 unidad de DNA ligasa del fago T4 (Roche Molecular Biochemicals) y el

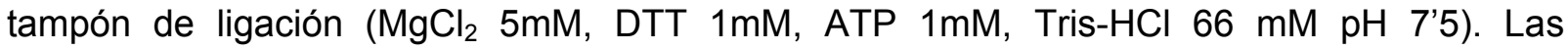
reacciones de ligación se realizaron a $4{ }^{\circ} \mathrm{C}$ durante toda la noche en el caso de utilizar el plásmido pGEM-T Easy y a $16^{\circ} \mathrm{C}$ y durante toda la noche en el otro caso.

\subsubsection{Digestión con enzimas de restricción}

Para cada enzima de restricción se utilizó el tampón y las condiciones recomendadas por las distintas casas comerciales. Las digestiones se llevaron a cabo en tubos de 1'5 ml con 5-10 $\mathrm{u} / \mu \mathrm{g}$ DNA, durante al menos $3 \mathrm{~h}$ a la temperatura óptima para cada enzima.

\subsubsection{Defosforilación de extremos cohesivos ( $5^{\prime}$ 'protuberantes)}

La reacciones de defosforilación se realizaron con fosfatasa alcalina de intestino de ternera (CIP, Boehringer Mannheim). Las reacciones se llevaron a cabo mezclando $5 \mu \mathrm{g}$ de vector plasmídico linearizado, $10 \mu \mathrm{l}$ de tampón 10x (0'5 M Tris-HCl, 1mM EDTA, pH 8'5), CIP 0'5 $\mathrm{u} / \mu \mathrm{g}$ DNA y $\mathrm{H}_{2} \mathrm{O}$ hasta completar un volumen de $100 \mu \mathrm{l}$. La mezcla se incubó 30 min a $37^{\circ} \mathrm{C}$, añadiendo nuevamente 0 ' $5 \mathrm{u} / \mu \mathrm{g}$ DNA CIP tras ese tiempo e incubando de nuevo $30 \mathrm{~min}$ a 37 ${ }^{\circ} \mathrm{C}$. La reacción se paró con $2 \mu \mathrm{l}$ de 0’5 M EDTA por cada $100 \mu \mathrm{l}$ de volumen total de reacción, calentando 20 min a $70^{\circ} \mathrm{C}$. La solución se extrajo 2 veces con fenol/cloroformo, se precipitó con 1/10 v $3 \mathrm{M} \mathrm{NaOAc}$ pH 5'2, 2'5 v EtOH absoluto y $1 \mu$ l de glicógeno (Boehringer Mannheim) y el precipitado de DNA se resuspendió en un volumen adecuado (unos $15 \mu \mathrm{l}$ ) procediendo a su cuantificación mediante electroforesis en gel de agarosa.

\subsection{Amplificación de DNA por reacción en cadena de la polimerasa ( $P C R)$}

Se utilizó la reacción en cadena de la polimerasa (PCR) con dos finalidades: amplificar fragmentos de DNA que posteriormente se utilizarían para ser ligados a vectores 
plasmídicos, y para amplificar el fragmento que contenía los genes barnasa y barstar insertados en el DNA genómico de plantas de tomate transformadas.

Las reacciones de amplificación de DNA plasmídico, se llevaron a cabo en un volumen total de $50 \mu \mathrm{l}$, a partir de 10-50 ng de DNA molde, $1 \mu \mathrm{M}$ de cebadores específicos del fragmento a amplificar o del plásmido donde éste se encontraba clonado, $\mathrm{dN}_{4} \mathrm{TPs}_{200 \mu \mathrm{M}}$, $\mathrm{KCl} 50 \mathrm{mM}, \mathrm{MgCl}_{2}$ 1'5 mM, Tris- $\mathrm{HCl} 10 \mathrm{mM} \mathrm{pH}$ 8'3 y 2'5 unidades de polimerasa de Thermus aquaticus (Taq polimerasa, Roche Molecular Biochemicals).

Para la amplificación del fragmento que contenía los genes barnasa y barstar insertados en el genoma de plantas transgénicas de tomate (cv. Micro-Tom), se llevó a cabo la reacción de PCR usando los oligos Ribo 1 e Inhi 2 (Tabla 6). Estas reacciones se llevaron a cabo en un volumen total de $20 \mu \mathrm{l}$, a partir de 50-100 ng de DNA genómico, 0,6 $\mu \mathrm{M}$ de cebadores específicos, dN ${ }_{4}$ TPs $200 \mu \mathrm{M}, \mathrm{KCl} 50 \mathrm{mM}, \mathrm{MgCl}_{2}$ 1'5 mM, Tris- $\mathrm{HCl} 10 \mathrm{mM} \mathrm{pH}$ 8'3, 2'5 unidades de polimerasa de Thermus aquaticus (Taq polimerasa, Roche Molecular Biochemicals). Las reacciones se desarrollaron en un termociclador Perkin Elmer 2400 en las siguientes condiciones: 1 ciclo a $94^{\circ} \mathrm{C} 2 \mathrm{~min} ; 30$ ciclos de $94{ }^{\circ} \mathrm{C} 30 \mathrm{~s} ; \mathrm{T}^{\circ} \mathrm{C} 30 \mathrm{~s} ; 72{ }^{\circ} \mathrm{C}$ $\mathrm{T}_{\text {ext }}$ min, y 1 ciclo final a $72{ }^{\circ} \mathrm{C}$ durante $10 \mathrm{~min}$. En cada reacción la temperatura de anillamiento $(\mathrm{T})$ se estimó en función de la temperatura Tm (temperatura de fusión estimada) de los cebadores empleados (Tabla 6); el tiempo de extensión utilizado dependía de la longitud del fragmento a amplificar; en general se utilizó 1 min por cada $\mathrm{Kb}$ de producto a esperado.

\subsection{Purificación de fragmentos de DNA a partir de geles de agarosa}

Tras separar las muestras de DNA mediante electroforesis en geles de agarosa/TBE, las bandas de interés se cortaron del gel con una cuchilla y el DNA contenido en las mismas se purificó mediante el sistema QIAquick Gel Extraction Kit (Qiagen), siguiendo las recomendaciones del fabricante. La extracción y purificación de los fragmentos de DNA por este método se basa en la solubilización de la agarosa y la adsorción selectiva de los ácidos nucleicos en una membrana de silicagel, en presencia de una elevada concentración de sal. La elución del DNA se llevó a cabo en 10 mM Tris- $\mathrm{HCl}$ pH 8.

\subsection{Secuenciación}

La secuenciación de fragmentos de DNA clonados se llevó a cabo según el protocolo de secuenciación enzimática desarrollado por Sanger et al., (1977) de modo automático en un secuenciador "ABI PRISM 377" (Perkin Elmer). Para ello, el DNA extraído según el protocolo de aislamiento y purificación de DNA plasmídico del sistema QIAGEN-tip100 descrito en el 
apartado 4.1.2 se llevó a una concentración de 0'2 $\mu \mathrm{g} / \mu \mathrm{l}$, y se amplificó con Ampli Taq DNA polimerasa en presencia de ddNTPs, cada uno de ellos marcado con un fluoróforo diferente (Perkin Elmer).Se utilizaron los cebadores propios del vector plasmídico pGEM- T Easy, T7 y SP6 (Tabla 6).

\section{AISLAMIENTO Y PURIFICACIÓN DE ÁCIDOS NUCLÉICOS}

\subsection{Aislamiento de DNA plasmídico}

\subsubsection{Aislamiento de DNA plasmídico en Escherichia coli}

Para las preparaciones de DNA plasmídico a pequeña escala se utilizó el método de la lisis alcalina tal como lo describen Sambrook et al., (1989), partiendo de un cultivo de $3 \mathrm{ml}$ crecido durante una noche en medio líquido LB suplementado con el correspondiente antibiótico. Las preparaciones de DNA plasmídico a media o gran escala, se realizaron a partir de cultivos, crecidos durante una noche en $100 \mathrm{ml}$ o $500 \mathrm{ml}$ de medio líquido LB suplementado con antibiótico, según el procedimiento de extracción y purificación de DNA plasmídico de los sistemas de Qiagen Plasmid Midi Kit (columnas Qiagen tip-100) y Qiagen Plasmid Maxi Kit (columnas Qiagen tip-500), respectivamente, siguiendo las instrucciones del fabricante

\subsubsection{Aislamiento de DNA plasmídico de Agrobacterium tumefaciens}

Para las preparaciones a pequeña escala de DNA plasmídico de Agrobacterium se utilizó el método de la lisis alcalina descrito por Sambrook et al., (1989) con ligeras modificaciones. Se partía de un cultivo de $3 \mathrm{ml}$, crecido durante una noche en medio líquido LB suplementado con $50 \mu \mathrm{g} / \mu \mathrm{l}$ kanamicina. El sedimento de células resultante de centrifugar el cultivo se resuspendió en $100 \mu \mathrm{l}$ de solución I y se trató tal como se describe en Sambrook et al., (1989). Al sobrenadante resultante de la centrifugación a que se somete el lisado obtenido tras añadir la solución III se le añadió $900 \mu \mathrm{l}$ de etanol absoluto y se incubó $30 \mathrm{~min}$ a $-80^{\circ} \mathrm{C}$. Tras centrifugar a $12000 \mathrm{rpm} 5 \mathrm{~min}$ a temperatura ambiente, el precipitado se lavó con etanol $70 \%$, se secó y se resuspendió en $25 \mu$ de TE $(1$ mM EDTA, 10 mM Tris-HCl pH 8).

La pureza de la preparación de DNA obtenida por este procedimiento no era suficientemente alta para realizar análisis de restricción del plásmido. Para solventar este problema, una alícuota de $1 \mu \mathrm{l}$ de esta preparación de DNA se utilizaba para transformar $E$. 
coli. De uno de los clones transformantes de E. coli obtenidos de ese modo, se hacía una nueva preparación de DNA plasmídico que se utilizaba para los análisis pertinentes.

\section{EXTRACCIÓN DE DNA GENÓMICO DE TOMATE}

Para confirmar la presencia de los genes foráneos en las plantas presuntamente transgénicas, se ha utilizado el análisis molecular basado en la técnica de reacción en cadena de la polimerasa (PCR). Para ello, se requiere la extracción de DNA genómico, para ser utilizado como DNA molde en la reacción de PCR.

La extracción de DNA genómico se realizó empleando el protocolo de Rogers y Bendich (1984). Se congelaron aproximadamente $200 \mathrm{mg}$ de tejidos de hoja verde utilizando nitrógeno líquido y se trituraron en un tubo eppendorf mediante un émbolo metálico hasta obtener un polvo muy fino. Se añadió $300 \mathrm{ml}$ de tampón CTAB×2 [2\% (p/v) CTAB, $100 \mathrm{mM}$ Tris- $\mathrm{HCl} \mathrm{pH}$ 8'0, 20 mM EDTA, 1'4 M NaCl, 1\% PVP (Mr 40000)] que se calentó previamente a $65^{\circ} \mathrm{C}$ para poder pipetear correctamente. Se mezcló por inversión del tubo y se dejó incubando a $65^{\circ} \mathrm{C}$. Cuando se terminó de añadir este tampón a la última muestra y se dejó la misma incubando 10 minutos, tras lo cual se sacaron del incubador y se dejaron enfriar 5 min a temperatura ambiente. Transcurrido este tiempo, se añadió $300 \mu \mathrm{l}$ de cloroformo isoamílico (24:1), se mezcló y se centrifugó durante 10 min a 11000 rpm para separar las fases. Se recogieron aproximadamente $300 \mu \mathrm{l}$ de sobrenadante y se añadió $30 \mu \mathrm{l}$ de tampón CTAB×10 [10\% $(\mathrm{p} / \mathrm{v})$ CTAB, 0’7 M NaCl) precalentado a $65^{\circ} \mathrm{C}$. Se mezcló y añadieron nuevamente $300 \mu \mathrm{l}$ de cloroformo isoamílico, y después se centrifugaron las muestras con las condiciones anteriores. Al sobrenadante obtenido se le añadió el mismo volumen del tampón de precipitación CTAB [1\% (p/v) CTAB, 50 mM Tris- $\mathrm{HCl} p H$ 8'0, 10mM EDTA)], tras lo cual apareció enseguida el precipitado que fue recogido mediante centrifugación en microcentrífuga durante $10 \mathrm{~min}$ a $11000 \mathrm{rpm}$. Se descartó el sobrenadante y se resuspendió el precipitado en 0'3 ml de tampón TE salino (10 mM Tris- $\mathrm{HCl}$ pH 8'0, 1mM EDTA, 1M NaCl). Se volvió a precipitar con 0'6 ml de etanol absoluto y finalmente se recogió el precipitado que contenía el DNA tras centrifugación en microcentrífuga a $11000 \mathrm{rpm}$ durante $10 \mathrm{~min}$. Se precipitó con etanol 80\% y se dejó secar. El DNA se disolvió en $50 \mu \mathrm{l}$ de TE × 0'1 (1mM Tris$\mathrm{HCl}$ pH 8'0, 0'1 mM EDTA) y se almacenó a $-20^{\circ} \mathrm{C}$.

La concentración de DNA se estimó mediante electroforesis en un gel de agarosa al 0'8 \% utilizando las técnicas y reactivos habituales de análisis de DNA (Maniatis, 1982). 


\section{TRANSFORMACIÓN DE BACTERIAS}

Las cepas que se emplearon en las transformaciones fueron la $\mathrm{DH} 5 \mathrm{a}$ de Escherichia coli y las cepas C58 pMP90 y LBA4404 de Agrobacterium tumefaciens.

\subsection{Preparación de células competentes y métodos de transformación}

\subsubsection{Transformación por electroporación}

La preparación de células competentes para su transformación mediante electroporación se llevó acabo según los protocolos descritos en el catálogo Pulse controller, Accesory for bacterial and fungal electro-transformation (BioRad), en el caso de E.coli, y según Wen-jun y Forde (1989) en el caso de A.tumefaciens.

Tras descongelar en hielo una alícuota de $40 \mu \mathrm{l}$ de células competentes preparadas mediante sucesivos lavados de glicerol, se añadió $1 \mu \mathrm{l}$ de vector transformante. La mezcla se introdujo en una cubeta de 0'1 cm de separación entre electrodos (BioRad), previamente enfriada en hielo, y se sometió a un pulso eléctrico con un aparato Gene Pulser ${ }^{\mathrm{TM}}$ (BioRad). Las condiciones de electroporación fueron $200 \Omega, 25 \mu \mathrm{F}$ y 1'8 kV, para E.coli, y $400 \Omega, 25 \mu \mathrm{Fy}$ $1 ' 8 \mathrm{kV}$, para A.tumefaciens. Después del pulso eléctrico se adicionó $1 \mathrm{ml}$ de LB y se incubó 1 h a $37^{\circ} \mathrm{C}$ y a $200 \mathrm{rpm}$ para E.coli y $3 \mathrm{~h}$ a $28^{\circ} \mathrm{C}$ y a $200 \mathrm{rpm}$ para A.tumefaciens.

\subsubsection{Selección de recombinantes bacterianos}

La selección de recombiantes bacterianos se llevó a cabo mediante la siembra de las células bacterianas transformadas en placas con medio LB suplementado con el antibiótico al cual confería resistencia el plásmido en estudio, y en el caso que el plásmido permitiese selección por color, se añadía $40 \mu \mathrm{l}(25 \mathrm{mg} / \mathrm{ml})$ de IPTG y $25 \mu \mathrm{l}(20 \mathrm{mg} / \mathrm{ml})$ de X-Gal al medio de cultivo sólido.

Los antibióticos utilizados para la selección de recombinantes bacterianos y la concentración a la que fueron usados, aparecen en la tabla 4.

Tabla 4. Antibióticos utilizados y sus concentraciones

\begin{tabular}{ll}
\hline Antibiótico & Concentración \\
\hline Ampicilina & $100 \mu \mathrm{g} / \mu \mathrm{l}$ para E. coli. \\
Kanamicina & $25 \mu \mathrm{g} / \mu \mathrm{l}$ para E. coli. \\
& $50 \mu \mathrm{g} / \mu \mathrm{l}$ para A. tumefaciens. \\
\hline
\end{tabular}




\section{TRANSFORMACIÓN DE PLANTAS}

\subsection{Diseño de las construcciones para la transformación de plantas}

\subsubsection{Diseño de la construcción pBI-END1::barnasa-barstar}

Para ensayar si la expresión del gen citotóxico barnasa en aquellos tejidos de la antera donde END1 es activo, era capaz de producir androesterilidad en plantas transgénicas de Arabidopsis, tabaco y tomate, se realizó la construcción pBI-END1::barnasa-barstar.

Para ello se partió de la construcción pBl101-F3 (Figura 12). Esta construcción contenía 2731 pb de la región promotora de END1 aislada del rastreo de una genoteca genómica de guisante. La región comprendía desde el fragmento -2736 hasta el nucleótido -6 de la región 5', tomándose como nucleótido +1 el primer nucleótido del cDNA aislado previamente (clon 162) de una genoteca de cDNA de flores de guisante (Gómez, 2000; Gómez et al., 2004) (Figura 16). El fragmento -2736/-6 de la región promotora de END1 estaba fusionado al gen uidA que codifica la enzima $\beta$ - glucuronidasa (GUS) (Gómez, 2000; Gómez et al., 2004). Este gen fue liberado con las enzimas de restricción $\mathrm{BamHI}$ y Sacl y el fragmento correspondiente al plásmido pBI101 más el promotor de END1 fue extraído del gel de agarosa. El fragmento barnasa-barstar (Figura 17) previamente clonado en el sitio BamHI del plásmido pBluescript KS (+) (Stratagene), fue amplificado utilizando los oligos Ribo 1 e Inhi 2. Con el primero se mantiene el sitio de corte para la enzima BamHI del clon original a nivel del ATG de la barnasa, y el último crea sitio de corte para Sacl a nivel del codón de parada del gen barstar. El fragmento producto de la reacción de PCR, se ligó al vector pGEM-T Easy (Promega), y se liberó posteriormente con las enzimas BamHI y Sacl. Este inserto fue clonado en el sitio que crearon estas mismas enzimas en la construcción pBI-END1, creándose así la construcción pBI-END1::barnasa-barstar (Figura 12).

\subsubsection{Diseño de la construcción pBI-END1::barstar}

Para realizar la construcción pBI-END1-barstar, se partió igualmente de la construcción pBI101-F3 (Figura 13) y se llevó a cabo el mismo proceso que para la construcción anterior hasta obtener el fragmento que contenía el plásmido pBI101 y la región promotora de END1 con extremos BamHl y Sacl.

El fragmento correspondiente al gen barstar fue amplificado por PCR usando como DNA molde el fragmento barnasa-barstar (Figura 17) clonado en pBluescript KS (+) (Stratagene) y los oligos Inhi1 e Inhi 2, que introducen un sitio de restricción BamHI a nivel del ATG del gen barstary Sacl a nivel del codón de parada, respectivamente. 
pBI101-F3

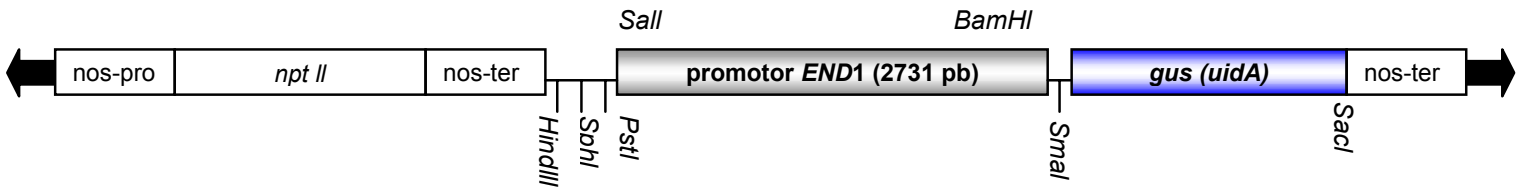

pBI-END1::barnasa-barstar

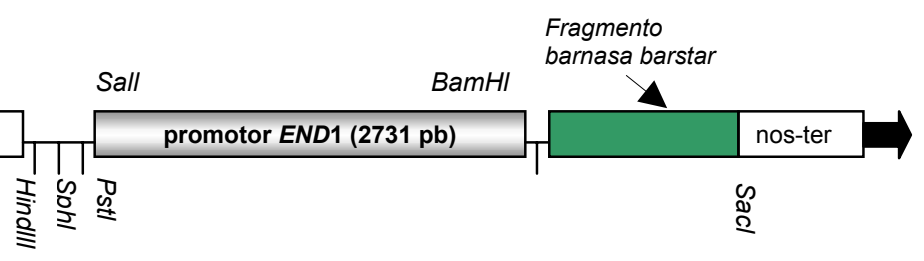

Figura 12. Representación esquemática de la construcción pBI-END1::barnasa-barstar y la construcción de partida pBI101-F3. El plásmido pBI101 consta del promotor constitutivo de la nopalina sintetasa (nos-pro) fusionado al gen nptll que confiere resistencia a kanamicina, el gen uidA que codifica la enzima de la $\beta$-glucuronidasa (GUS) y la señal de poliadenilación del gen de la nopalina sintetasa (nos-ter) en los extremos 3' de ambos genes. En la construcción pBI-END1::barnasa-barstar el gen uidA ha sido sustituido por el fragmento que contiene los genes barnasa-barstar cuya secuencia aparece en la figura 17.

pBI101-F3

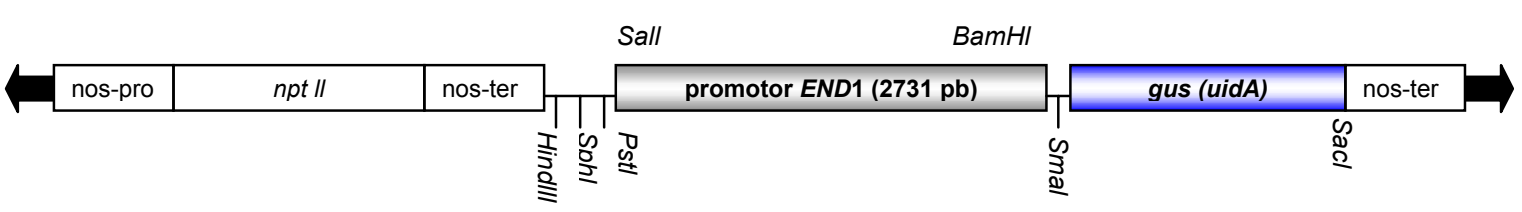

pBI-END1::barstar

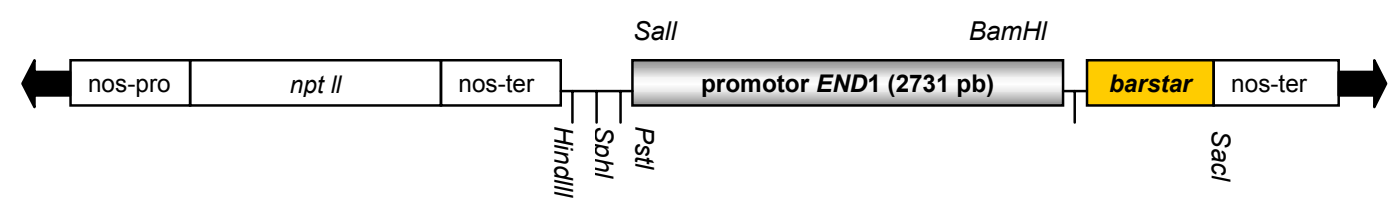

Figura 13. Representación esquemática de la construcción pBI-END1::barstar y la construcción de partida pBI101-F3. El plásmido pBI101 consta del promotor constitutivo de la nopalina sintetasa (nos-pro) fusionado al gen nptll que confiere resistencia a kanamicina, el gen uidA que codifica la enzima de la $\beta$-glucuronidasa (GUS) y la señal de poliadenilación del gen de la nopalina sintetasa (noster) en los extremos 3' de ambos genes. En la construcción pBI-END1::barstar el gen uidA ha sido sustituido por el gen barstar cuya secuencia aparece en la figura 17 
El fragmento producto de la reacción de PCR, se ligó al vector pGEM-T Easy (Promega), y se liberó posteriormente con las enzimas $\mathrm{BamHI}$ y Sacl. Este inserto fue clonado en el sitio que crearon estas mismas enzimas en la construcción pBI-END1, generándose así la construcción pBI-END1::barstar con la que se transformaron plantas de Arabidopsis thaliana (Figura 13).

\subsubsection{Diseño de las construcciones utilizadas para el análisis funcional del promotor de END1}

\subsubsection{Diseño de las construcciones con deleciones de la región promotora de END1}

Para identificar y caracterizar los elementos reguladores en cis involucrados en la regulación de la transcripción del gen END1, se realizaron construcciones con deleciones sucesivas de la región 5' anterior al inicio de la traducción de este gen fusionados al gen uidA. Con estas construcciones se transformaron plantas de Arabidopsis thaliana.

Los fragmentos de la región promotora de END1 (incluyendo los amplificados en el apartado 7.1.3.2) se amplificaron en cada caso mediante la técnica de PCR usando como DNA molde el fragmento de DNA genómico de 2731 pb de la región 5' de END1 (fragmento comprendido entre -2736/-6) derivado del rastreo de la genoteca genómica y clonado previamente en el plásmido pBluescript KS (+) (Stratagene) (Gómez, 2000; Gómez et al., 2004).

Los fragmentos utilizados para estas construcciones contenían las deleciones sucesivas en 5' de -986/-6, -685/-6, -426/-6, -366/-6, -336/-6 y-309/-6.

El fragmento comprendido entre el final de la región 5' y-986 pb del gen END1, fue amplificado con los oligos MED3 y MED1.

Para amplificar el fragmento correspondiente a la deleción de -685/-6 de la región 5' del gen END1, se usaron los oligos MED4 y MED1.

Las parejas de oligos Del-427 y MED1 y Del-366 y MED1 se usaron para amplificar los fragmentos correspondientes a las regiones 5' del gen END1 de $-427 /-6$ y $-366 /-6$ respectivamente.

Por último, se amplificaron los fragmentos de -336/-6 y de -309/-6 de la región 5' del gen END1 con las parejas de oligos Del-336 y MED1 y MED 5 y MED1 respectivamente. Todos los cebadores utilizados para las reacciones de amplificación de cada uno de los fragmentos de la región 5' de END1 aparecen representados en la tabla 6.

El primero de los oligos utilizados en cada caso, introducía sitio de corte para la enzima Sall y el segundo introducía sitio de restricción para la enzima BamHI. 

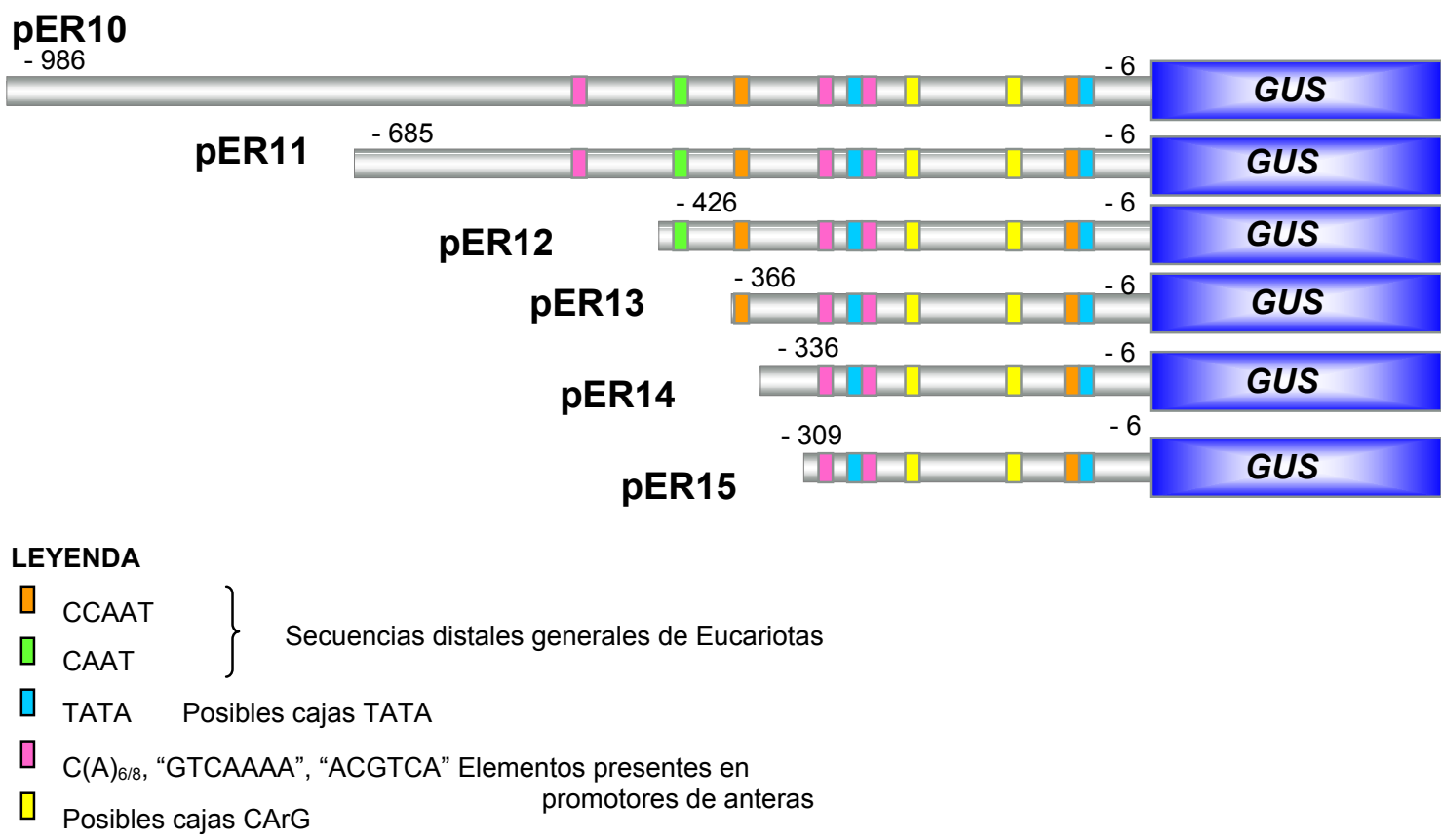

Figura 14. Representación esquemática de las deleciones sucesivas del promotor de END1 utilizadas para el análisis funcional del mismo en Arabidopsis thaliana. El plásmido utilizado fue el pBI101 que consta del promotor constitutivo de la nopalina sintetasa (nos-pro) fusionado al gen nptII que confiere resistencia a kanamicina, el gen uidA que codifica la enzima de la $\beta$-glucuronidasa (GUS) y la señal de poliadenilación del gen de la nopalina sintetasa (nos-ter) en los expremos 3' de ambos genes.

Cada uno de los fragmentos generados se clonaron individualmente en el vector plasmídico PGEM-T Easy (Promega).

Posteriormente, todos los insertos clonados se liberaron con las enzimas de restricción Sall y BamHI y se clonaron en el plásmido pBl101 dirigiendo la expresión del gen de la $\beta$ glucuronidasa. Al final del proceso se generaron seis construcciones diferentes que se resumen esquemáticamente en la figura 14.

\subsubsection{Diseño de las construcciones con fragmentos de la región promotora de END1 con deleciones internas de posibles elementos reguladores}

Para estudiar la importancia de determinadas regiones específicas dentro de la región promotora de END1 en la regulación de la transcripción, se generaron 4 construcciones.

En la primera de ellas, del fragmento $-685 /-6$ de la región 5' de END1 se eliminaron las secuencias entre los -346 pb y -310 pb. Para ello se amplificaron dos fragmentos: el primero incluía la secuencia comprendida entre los -685 pb y -347 pb de la región 5' del gen END1 y el segundo fragmento comprendía la región correspondiente entre los -309 y -6 pb de la región 5'. Para amplificar el primero de los dos fragmentos se usaron los oligos MED4 y -366 $\mathrm{REV}$, creándose los sitios de restricción Sall y BamHI respectivamente. El segundo de los 
dos fragmentos se amplificó usando los oligos -309 Bam y MED1, que creaban ambos sitios de corte para la enzima de restricción BamHI. Los fragmentos amplificados se clonaron individualmente en el vector plasmídico pGEM-T Easy (Promega). El primer fragmento se liberó con las enzimas Sal l y BamHI, y se clonó en el plásmido pBI101.

El fragmento -309/-6 se liberó del vector pGEM-T Easy con la enzima BamHI, y posteriormente fue clonado a continuación del primer fragmento en el sitio BamHI de la construcción generada anteriormente. Esto dio lugar a la construcción pER16 (Figura 15).

La segunda construcción eliminaba de igual manera, la secuencia comprendida entre los 346 y -309 pb de END1 pero en el contexto de -366 pb de la región promotora. Para realizar esta construcción se utilizó como DNA molde en la reacción de PCR, la construcción pER16, y los oligos -366 Sall y MED1Bglll que creaban sitios de restricción para Sall y Bglll respectivamente. El fragmento amplificado se clonó en el plásmido pGEM-T Easy, y fue liberado del mismo con las enzimas antes mencionadas. El resultado fue clonado en el vector pBI101, creándose la construcción pER17 (Figura 15).

La tercera construcción de las construcciones con deleciones internas comprendía la región del promotor -366/-6, donde se excluye la secuencia comprendida entre los -224 y -209 pb de la región 5' de END1 donde se encuentra una posible caja CArG (Motivo CArG 1). Para ello se amplificaron dos fragmentos donde el primero incluía la secuencia comprendida entre los $366 \mathrm{pb}$ y $-225 \mathrm{pb}$ del promotor y el segundo la comprendida entre los $-208 \mathrm{pb}$ y el final de la región 5' (-6 pb). Para amplificar el primero de los dos fragmentos se utilizaron los oligos Del 366 y -225 REV que creaban sitios de restricción para las enzimas Sall y BamHI respectivamente. Los oligos Del -208 y MED1 se usaron para amplificar el segundo de los fragmentos, creándose los sitios de corte $\mathrm{Bg} / \mathrm{ll}$ y $\mathrm{BamHl}$ respectivamente. Ambos fragmentos se clonaron individualmente en el vector pGEM-T Easy. La construcción que generó la unión del fragmento de -366/-225 pb de la región promotora en el plásmido pGEM-T Easy, fue digerida con la enzima BamHI, y el resultado fue extraído de gel de agarosa. Posteriormente, el fragmento -208/-6, previamente clonado en pGEM-T Easy fue liberado con las enzimas de restricción BgIII y BamHI y clonado en el sitio BamHI generado en la construcción que contenía el primer fragmento. Después de comprobar la orientación de los fragmentos, se liberó el fragmento Sall-BamHI que comprendía los antes descritos y se clonó en plásmido pBI101 dando lugar a la construcción pER18 (Figura 15).

La última de las construcciones con deleciones internas del promotor de END1, comprendía el fragmento de -366/-6 pb de la región promotora excepto los nucleótidos de las posiciones entre los $-114 \mathrm{pb}$ y $-100 \mathrm{pb}$ de dicha región. 


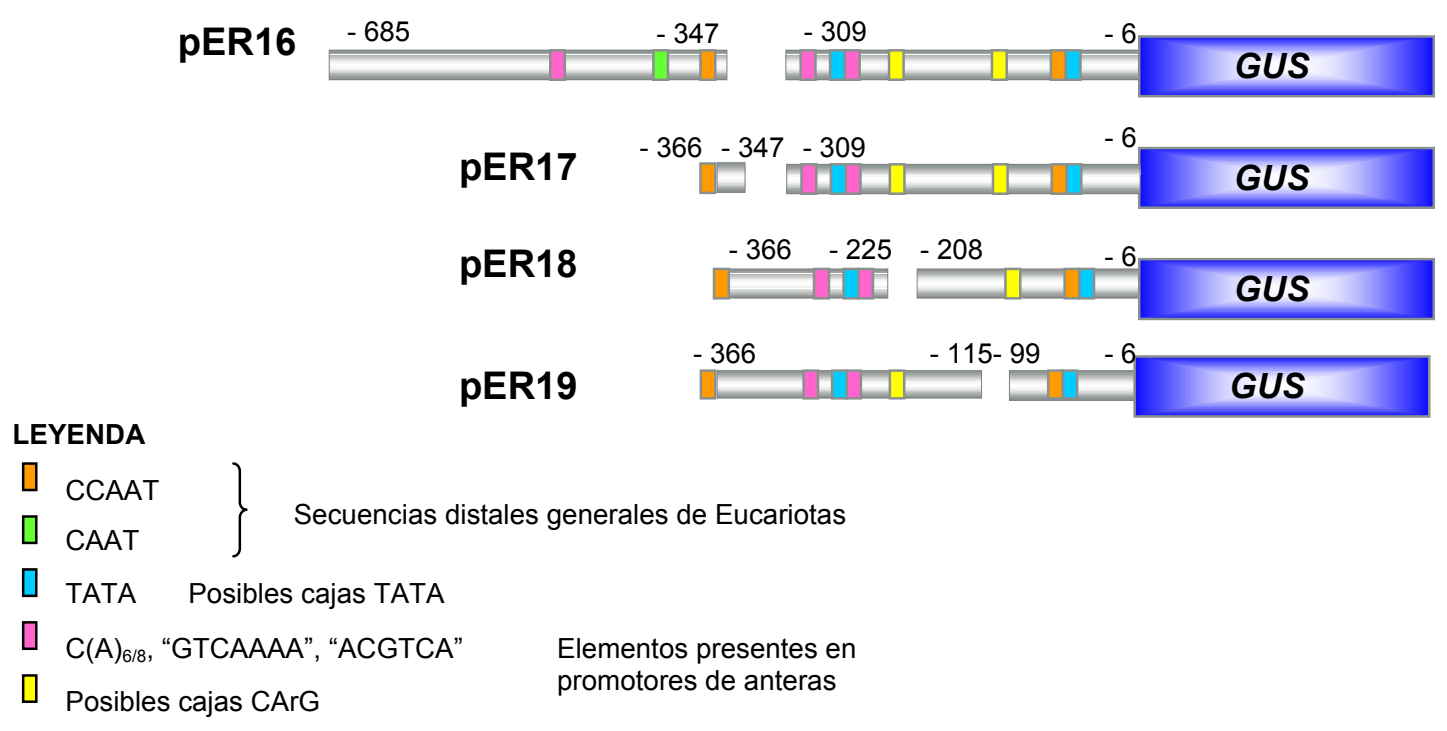

Figura 15. Representación esquemática de las construcciones con fragmentos de la región promotora de END1 con deleciones internas de posibles elementos reguladores utilizadas en el análisis funcional del mismo en Arabidopsis thaliana. El plásmido utilizado fue el pBI101 que consta del promotor constitutivo de la nopalina sintetasa (nos-pro) fusionado al gen nptll que confiere resistencia a kanamicina, el gen uidA que codifica la enzima de la $\beta$-glucuronidasa (GUS) y la señal de poliadenilación del gen de la nopalina sintetasa (nos-ter) en los extremos 3' de ambos genes.

La secuencia eliminada, incluía la posible caja CArG (motivo CArG2). La amplificación de los fragmentos se llevó a cabo con dos parejas de oligos: La primera pareja de oligos -366 Sall y -115 REV, amplificaron el primer fragmento -366/-115 creando sitios de restricción para las enzimas Sall y BamHI respectivamente. La segunda pareja de oligos -99 Bglll y MED1+, amplificaba el fragmento $-99 /-6$ y crearon sitios de restricción para BgIll y BamHI respectivamente. Cada fragmento se clonó individualmente en el plásmido pGEM-T Easy. La construcción que contenía el primer fragmento en pGEM-T Easy fue digerida con la enzima BamHI y fue usado posteriormente para la ligación con el fragmento -99/-6 pb que fue liberado de pGEM-T Easy con las enzimas BgIll y BamHI. Los fragmentos clonados se liberaron del pGEM-T Easy con las enzimas Sall y BamHI, y se volvieron a clonar en el vector pBI101, creándose la construcción pER19 (Figura 15).

Las construcciones con deleciones internas de posibles elementos reguladores del promotor de END1 aparecen representadas esquemáticamente en la figura 15.

\subsection{Transformación de Arabidopsis thaliana y análisis de las plantas transgénicas}

Para la transformación de plantas transgénicas de Arabidopsis thaliana se ha utilizado la planta silvestre del ecotipo Columbia (Col). La transformación se realizó siguiendo el protocolo de infiltración al vacío descrito por Bechtold et al., (1993). Aproximadamente unas 60 semillas de Arabidopsis se cultivaron en macetas de $11 \mathrm{~cm}$ de diámetro, tal y como se describe en el apartado 1.1.1.1. Transcurridas unas 2 semanas desde la siembra, se 
eliminaron algunas plantas con el fin de facilitar el crecimiento homogéneo y adecuado de la población. Una vez las plantas habían producido el escapo floral, cuando la última hoja caulinar se había separado unos 2-3 cm del ápice de la inflorescencia principal (altura de las plantas de 9 a $11 \mathrm{~cm}$ ), éste se decapitó para eliminar la dominancia apical e inducir así la proliferación de las inflorescencias laterales. El tiempo aproximado que transcurría desde la siembra hasta que se decapitaran era aproximadamente un mes y 5-6 días. Una vez decapitadas, las plantas se cultivaron unos 4 días más antes de la infiltración.

Tres días antes de la infiltración (día -3), se inoculó un tubo con $10 \mathrm{ml}$ de medio LB, conteniendo $100 \mu \mathrm{g} / \mathrm{ml}$ de rifampicina y $50 \mu \mathrm{g} / \mathrm{ml}$ de kanamicina, a partir de un glicerinado con la cepa C58 pMP90 de A. tumefaciens portadora de las construcciones de interés. Este se incubó durante toda la noche en oscuridad a $28^{\circ} \mathrm{C}$ con agitación de $200 \mathrm{rpm}$. Al cabo de este tiempo (día -2), se inoculó un matraz con $600 \mathrm{ml}$ de medio LB con kanamicina (50 $\mu \mathrm{g} / \mathrm{ml}$ ) con los $10 \mathrm{ml}$ del precultivo anterior y se incubó en las mismas condiciones durante 48 h. El día de la infiltración (día 0) el cultivo se recogió por centrifugación y el sedimento con las bacterias se resuspendió en $200 \mathrm{ml}$ de medio de infiltración (2'2 g/l sales MS (Duchefa), 5\% sacarosa, $1 \mathrm{mg} / /$ 6-BAP, $100 \mathrm{mg} / \mathrm{l} \mathrm{MES,} \mathrm{pH} \mathrm{5'9).} \mathrm{Antes} \mathrm{de} \mathrm{la} \mathrm{infiltración,} \mathrm{se} \mathrm{les} \mathrm{quitaron} \mathrm{a} \mathrm{las}$ plantas todas las silicuas fertilizadas así como las flores abiertas. Para la infiltración a vacío, las macetas se invertían y se introducían en una fiambrera que contenía los $200 \mathrm{ml}$ de la suspensión de Agrobacterium en medio de infiltración, de manera que no sólo los ápices florales sino también las hojas de roseta quedaban sumergidos en el líquido. El montaje se colocaba en una campana de vacío conectada a una bomba (Bomba EDWARDS RV3, 110120/220-240V, 50-60 Hz, monofásica A652-01-903) y se sometía a vacío durante 30 min en posición de alto vacío y caudal bajo "posición I"(presión total final: $3 \times 10^{-2} \mathrm{mbar}, 3 \mathrm{~Pa}$ ). E tiempo se empezaba a contar cuando la suspensión de Agrobacterium empezaba a burbujear. Pasado el tiempo de infiltración se sacaban las plantas de la campana y se secaban ligeramente, escurriéndolas sobre un trozo de papel absorbente. Las plantas así tratadas se cubrían con bolsas de plástico y se devolvían a las cabinas de cultivo donde se les permitía que continuaran creciendo bajo las condiciones descritas en el apartado 1.1.1.1. Durante los 2-3 días siguientes a la infiltración se iban haciendo agujeros en las bolsas, con el fin de aclimatar las plantas a las condiciones de humedad habituales, hasta que éstas se eliminaban definitivamente. Las plantas se cultivaron hasta obtener semillas maduras.

Alternativamente a la transformación de plantas de Arabidopsis thaliana con el método de Bechtold et al., (1993), en algunas ocasiones se utilizó una versión modificada de este método que se basa en la utilización del detergente Silwet L.77 (LEHLE SEEDS; Clough y Bent, 1998). En el momento de la infiltración, las plantas se mantenían sumergidas durante 8 s en la suspensión de Agrobacterium en medio de infiltración a la que se le había adicionado dicho detergente hasta una concentración final de 0’05\%; inmediatamente después, se les 
sometió a un pulso de vacío de $1 \mathrm{~min}$ utilizando las mismas condiciones que en el procedimiento anterior. El tratamiento de las plantas antes y después de la infiltración, así como la preparación de los cultivos de Agrobacterium fueron iguales que como se ha descrito con detalle para el procedimiento anterior.

Cuando las silicuas de las plantas transformadas estuvieron maduras se recogieron las semillas, se guardaron en bolsas de celofán y se incubaron en una estufa a $37^{\circ} \mathrm{C}$ durante al menos una semana. Para la selección de los transformantes primarios $\left(T_{1}\right)$, las semillas procedentes de plantas individuales $T_{1}$ se esterilizaron, se sembraron en cajas de Petri de 15 $\mathrm{cm}$ de diámetro con medio de selección con kanamicina y se cultivaron en cabinas de cultivo in vitro (ver apartado 1.1.1.2.). Después de 7-10 días desde la siembra, los transformantes eran claramente identificables por su color verde y sus raíces desarrolladas; en ese momento se transplantaron a alvéolos $\left(6^{\prime} 5 \times 6{ }^{\prime} 5 \times 5 \mathrm{~cm}\right)$ con una mezcla turba:vermiculita:perlita (1:1:1) y se trasladaron a un fitotrón para su cultivo bajo las condiciones descritas en el apartado 1.1.1.1.

Se analizó el fenotipo de la población correspondiente a la primera $\left(T_{1}\right)$ y segunda generación $\left(\mathrm{T}_{2}\right)$ de plantas transformadas con la construcción pBI-END1::barnasa-barstar, el de plantas transformadas con las construcciones que contenían las deleciones de la región promotora de END1 y el análisis fenotípico de plantas END1::barnasa-END1::barstar. Las plantas se observaban y se fotografiaban con una cámara Nikon F-601 M, acoplada a una lupa MZ8 (Leica). Las anteras de plantas END1::barnasa fueron fijadas y observadas por SEM y microscopía óptica según se indica en los apartados 2.2, 2.3, 2.4 y 2.5. Se sometió a análisis histoquímico de la actividad de la $\beta$-glucuronidasa a flores de plantas transformadas con las deleciones del promotor de END1.

Para el análisis fenotípico de plantas END1::barnasa de la generación $T_{2}$ se realizó un análisis de segregación del fenotipo androestéril como índice de la segregación del transgén para 4 líneas transgénicas independientes en función de la proporción de plantas estériles frente a plantas fértiles obtenidas.

Para ello, las semillas provenientes del cruce de líneas independientes $T_{1}$ con plantas silvestres, se sembraron en alvéolos individuales para cada una como se indica en el apartado 1.1.1.1. Se observó el fenotipo de las plantas resultantes en cuanto a morfología de las anteras y formación de frutos para cuantificar el porcentaje de esterilidad de las plantas germinadas.

En el caso del análisis de plantas END1::barnasa-END1::barstar, se realizó el análisis fenotípico de plantas descendientes del cruce entre una planta hemicigota de la línea END1::barnasa \& y una planta homocigota de la línea independiente END1::barstar ${ }_{14}$. Este análisis se hizo en función del fenotipo mostrado por las anteras y la formación de silicuas de las plantas resultantes. 
La descendencia del cruce citado anteriormente se sembró en alvéolos individuales como se indica en el apartado 1.1.1.1. Se observó el fenotipo de las anteras de las plantas resultantes y se realizó un conteo del número de silicuas formadas en cada planta.

Para el análisis fenotípico de plantas transformadas con las deleciones de la región 5' no codificante de END1, se realizó el análisis de la expresión del gen uidA en poblaciones correspondientes a las generaciones $T_{1}$. Este estudio se realizó mediante ensayo histoquímico de la actividad del gen de la $\beta$-glucuronidasa. Los ápices florales y flores se infiltraron mediante dos pulsos de vacío en una solución con tampón fosfato 0'1 M pH 7'0, ferricianida 0'5 mM, ferrocianida 0'5 mM, tritón X-100 al 0'1\% y ácido X-Glc A 2 mM, y se incubaron en ella a $37^{\circ} \mathrm{C}$ durante toda la noche. Posteriormente, se destiñeron con lavados de etanol al $70 \%$ durante 1 min y varios lavados con etanol al $96 \%$ hasta que los tejidos se tornasen casi transparentes. Por último, se cuantificaron las plantas que dieron positivas a la reacción histoquímica y los datos se recogieron en gráficas para su análisis.

\subsubsection{Búsqueda de plantas transgénicas homogigotas para END1::barstar}

Las plantas de Arabidopsis thaliana ecotipo Columbia (Col) se transformaron con la construcción pBI-END1::barstar y se obtuvieron transformantes primarios $\left(\mathrm{T}_{1}\right)$ como se indica en el apartado 7.2.

Se escogió la línea independiente $N^{0} 14$ y se obtuvieron sus generaciones $T_{2}$ y $T_{3}$.

La descendencia de plantas individuales de la generación $T_{2}$ (semillas $T_{3}$ ) se sembraron en placas con medio de selección con kanamicina como se indica en el apartado 1.1.1.2, y aquellas que resistieron en su totalidad en este medio, se consideraron descendientes de plantas homocigotas para el transgén en estudio. Se escogió la línea END1::barstar ${ }_{14}$ (1) para realizar los cruces con la línea END1::barnasa 8.

\subsection{Transformación de Nicotiana tabacum y análisis fenotípico de las plantas transformadas}

La transformación de plantas de Nicotiana tabacum se realizó siguiendo el método descrito por Horsh et al. (1984) con las modificaciones propuestas por Fisher y Guiltinan (1995).

Se inoculó un tubo con $5 \mathrm{ml}$ de medio LB, $10 \mathrm{mM} \mathrm{MgSO}_{4}, 100 \mu \mathrm{g} / \mathrm{ml}$ rifampicina y $50 \mu \mathrm{g} / \mathrm{ml}$ kanamicina a partir de un glicerinado con la cepa LBA4404 de A. tumefaciens portadora de la construcción de interés. Éste se incubó toda la noche en oscuridad a $28{ }^{\circ} \mathrm{C}$ con agitación de $200 \mathrm{rpm}$. Al cabo de este tiempo alícuotas de $500 \mu \mathrm{l}$ de ese cultivo se utilizaron para inocular dos matraces de $250 \mathrm{ml}$ con $50 \mathrm{ml}$ de medio LB, $10 \mathrm{mM} \mathrm{MgSO}_{4}$ y $50 \mu \mathrm{g} / \mathrm{ml}$ kanamicina que se incubaron en las mismas condiciones hasta que la $\mathrm{DO}_{600}$ alcanzó un valor comprendido 
entre 0'5-0'6. El cultivo resultante se recogió por centrifugación y el sedimento con las bacterias se resuspendió en la mitad de volumen de medio MSS líquido [4'4 g/l sales MS (Duchefa), 2\% sacarosa, $100 \mathrm{mg} / \mathrm{l} \mathrm{MES,} \mathrm{pH} \mathrm{5'9].}$

Secciones de hoja de Nicotiana tabacum cv. Petite Havana SR1 de $1 \mathrm{~cm}^{2}$, provenientes de plantas jóvenes (aproximadamente 4 semanas) propagadas en medio sólido MSS a partir de entrenudos, se sumergieron en la suspensión de Agrobacterium, dispuesta en una caja Petri de $9 \mathrm{~cm}$ de diámetro durante $10 \mathrm{~min}$. A continuación, los discos foliares se sacaron de la suspensión de Agrobacterium, se escurrieron, se colocaron con el envés hacia arriba sobre medio sólido MSS ( $3^{\prime} 5 \mathrm{~g} / \mathrm{l}$ phytagel) y se cocultivaron durante tres días a $25^{\circ} \mathrm{C}$ en oscuridad para facilitar la infección por Agrobacterium. Tras el cocultivo los discos foliares infectados se transfirieron a cajas con medio de regeneración y selección MSSABCK [medio MSS con 0'2 mg/l IAA, 2'2 mg/l 6-BAP, 400 mg/l carbenicilina (para inhibir el crecimiento del Agrobacterium) y $130 \mathrm{mg} / \mathrm{l}$ kanamicina (para seleccionar el crecimiento de las células que hubieran incorporado el T-DNA).

Las placas con los explantes se incubaron en cabinas de cultivo in vitro a $25^{\circ} \mathrm{C}$, bajo condiciones de fotoperiodo de día largo (ver apartado 1.1.1.4.), y cada 7-10 días se cambiaron a nuevas cajas con el mismo medio. Los brotes regenerados (uno de cada explante, para asegurar que se seleccionaban sucesos de transformación independientes) que iban apareciendo se cortaban evitando el callo y se transferían a frascos de $6 \mathrm{~cm}$ de diámetro x 9'5 cm de altura con medio de enraizamiento MSSACK (medio MSS sólido con 0'2 mg/l de IAA, 200 mg/l de carbenicilina y 130 mg/l de kanamicina). De cada brote enraizado, se aislaban dos entrenudos, cada uno con una hoja, que se transferían a frascos de medio MSSACK, a partir de los cuales se regeneraban dos plantas completas. Una de ellas se utilizaba para mantener una réplica en cultivo in vitro, mientras que la otra, una vez enraizada, se transfería a tierra. Para ello, los brotes enraizados se extrajeron de los frascos, se les eliminó los restos de medio de las raíces, se transplantaron a macetas de $13 \mathrm{~cm}$ de diámetro con una mezcla de turba:vermiculita (1:1) y se trasladaron al invernadero, donde se cultivaron bajo las condiciones descritas en el apartado 1.1.1.3.

El análisis fenotípico de la primera generación $\left(\mathrm{T}_{1}\right)$ de plantas END1::barnasa se llevó a cabo mediante del análisis de la morfología de las anteras de estas plantas por medio de fotografías realizadas con una cámara Nikon F-601 M, acoplada a una lupa MZ8 (Leica) y mediante la observación de las anteras a través de SEM y microscopía óptica. 


\subsection{Transformación de Lycopersicon esculentum (cv. Micro-Tom) y análisis de las plantas transgénicas}

La transformación genética de plantas de Lycopersicon esculentum (cv. Micro-Tom) se realizó utilizando el protocolo optimizado descrito por Ellul et al. (2003).

De plantas estériles de 12 días, cultivadas en medio de germinación (MG), se tomaron los cotiledones y se cortaron transversalmente en dos segmentos eliminando los extremos para aumentar la superficie de infección. Los explantes de cotiledón se transfirieron a placas Petri (24 explantes /placa), que contenían medio de precultivo (MPC), en las que permanecieron 48 horas en una estufa con oscuridad y a $28^{\circ} \mathrm{C}$, Transcurrido este tiempo, los explantes se sumergieron durante 6-8 minutos en $30 \mathrm{ml}$ del cultivo bacteriano y posteriormente se secaron con papel de filtro estéril para eliminar el exceso de bacterias. Se colocaron con el envés del cotiledón en contacto con el medio de cocultivo (MCC). Los explantes se incubaron con la bacteria durante 48 horas en una estufa con oscuridad a $26^{\circ} \mathrm{C}$, Concluido el período de cocultivo, los explantes se transfirieron durante 10-12 minutos a botes de cristal estériles con $150 \mathrm{ml}$ de medio de lavado (ML) más cefotaxima $(500 \mathrm{mg} / \mathrm{l})$ que detiene el crecimiento de Agrobacterium. Tras el lavado, los explantes se secaron sobre papel de filtro estéril y se colocaron el placas petri de $15 \mathrm{~mm} \times 90 \mathrm{~mm}$, que contenían medio organogénico sin presión selectiva (IK 4.0/4.0 + cefotaxima $400 \mathrm{mg} / \mathrm{l}$ ), donde permanecieron 48 horas en cámara de cultivo. Al transcurrir este tiempo, los explantes se transfirieron a placas Petri de $25 \mathrm{~mm} \times 90$ $\mathrm{mm}$, que contenían unos $20 \mathrm{ml}$ de medio selectivo de inducción organogénica y se subcultivaron cada tres semanas en estas condiciones. Los callos formados se separaron de los explantes a las 7-8 semanas aproximadamente, eliminando las zonas friables, y se subcultivaron cada 3 semanas en el medio de inducción de organogénesis IKZ 4.0/4.0/1.0 hasta que fueron apareciendo los brotes individuales que se separaron del callo y se transfirieron a medio de enraizamiento (ME). Estos brotes, una vez enraizados, desarrollaron estructuras vegetativas que nos permitieron obtener nuevas plantas mediante propagación clonal. Sobre estas estructuras vegetativas se realizaron los análisis moleculares y el análisis de ploidía a los transformantes primarios.

Las soluciones minerales, vitamínicas y medios de cultivos empleados aparecen a continuación: 
Tabla 5. Soluciones minerales y vitamínicas.

\begin{tabular}{lc}
\hline Macronutrientes & (mg/l) \\
\hline $\mathrm{NH}_{4} \mathrm{NO}_{3}$ & 1650 \\
$\mathrm{KNO}_{3}$ & 1900 \\
$\mathrm{CaCl}_{2} .2 \mathrm{H}_{2} \mathrm{O}$ & 440 \\
$\mathrm{MgSO}_{4} .7 \mathrm{H}_{2} \mathrm{O}$ & 370 \\
$\mathrm{KH}_{2} \mathrm{PO}_{4}$ & 170 \\
\hline & \\
\hline $\mathrm{Micronutrientes}^{\mathrm{KI}}$ & $(\mathbf{m g} / \mathbf{l})$ \\
\hline $\mathrm{H}_{3} \mathrm{BO}_{3}$ & $0{ }^{\prime} 83$ \\
$\mathrm{MnSO}_{4} .4 \mathrm{H}_{2} \mathrm{O}$ & $6{ }^{\prime} 20$ \\
\hline
\end{tabular}

\section{Medio de germinación (MG)}

\begin{tabular}{lc}
\hline MG & $(\mathbf{g} / \mathbf{l})$ \\
\hline Solución mineral & $100 \%$ \\
Sacarosa & 10 \\
Agar & 8 \\
\hline
\end{tabular}

Medio de precultivo (1 litro) (MPC)

$(g / l)$

\begin{tabular}{lr}
\hline Solución mineral (MS) & $100 \%$ \\
\hline Sacarosa $(\mathrm{g})$ & 30 \\
Myo-inositol $(\mathrm{mg})$ & 100 \\
Vitaminas SH (ml) & 10 \\
IAA $(\mathrm{mg})$ & 4 \\
Kinetina (mg) & 4 \\
Agar $(\mathrm{g})$ & 8 \\
\hline
\end{tabular}

Medio de cocultivo (1 litro) (MCC) (g/l)

\begin{tabular}{lr}
\hline Solución mineral $(\mathrm{MS})$ & $100 \%$ \\
\hline Sacarosa $(\mathrm{g})$ & 30 \\
Myo-inositol $(\mathrm{mg})$ & 100 \\
Vitaminas SH $(\mathrm{ml})$ & 10 \\
IAA $(\mathrm{mg})$ & 4 \\
Kinetina $(\mathrm{mg})$ & 4 \\
Acetociringona $(\mu \mathrm{M})$ & 200 \\
Agar $(\mathrm{g})$ & 8 \\
\hline
\end{tabular}




\begin{tabular}{lc} 
Medio de lavado (1 litro) (ML) & (g/l) \\
\hline Solución mineral (MS) & 100\% \\
\hline Sacarosa $(\mathrm{g})$ & 100 \\
Myo-inositol (mg) & 600 \\
Cefotaxima $(\mathrm{mg})$ & 20 \\
\hline
\end{tabular}

Medios de inducción de organogénesis (MIO) (1 litro)

\begin{tabular}{lc}
\hline IK 4.0/4.0 (para precultivo) & (g/l) \\
\hline Solución mineral (MS) & 30 \\
Sacarosa (g) & 100 \\
Myo-inositol (mg) & 10 \\
Vitaminas SH (ml) & 4 \\
IAA (mg) & 4 \\
Kinetina (mg) & 8 \\
Agar (g) & \\
\hline & $1 \mathbf{g} / \mathbf{l})$ \\
\hline IKZ 4.0/4.0/1.0 (para 1 litro) & 30 \\
Solución mineral (MS) & 100 \\
Sacarosa (g) & 10 \\
Myo-inositol (mg) & 4 \\
Vitaminas SH (ml) & 4 \\
IAA (mg) & 1 \\
Kinetina (mg) & $80 \%$ \\
Zeatina (mg) & 4 \\
Agar (g) & \\
\hline
\end{tabular}

\section{Medio de enraizamiento (ME)}

\begin{tabular}{lr}
\hline ME & $\mathbf{( g / l )}$ \\
\hline Solución mineral (MS) & 20 \\
Sacarosa & 0.1 \\
Myo-inositol & 0.001 \\
Tiamina-HCl & 0.0001 \\
IAA & 8 \\
Agar & $800 \%$ \\
\hline
\end{tabular}

\section{Nota:}

1. El pH del medio se ajustó a 5.7 con $\mathrm{KOH}$ antes de añadir el agente gelificante (agar).

2. Los medios de cultivo se esterilizaron por calor húmedo en autoclave, a $115^{\circ} \mathrm{C}$ durante 30 minutos. 
3. Las vitaminas se disolvieron en agua, se prepararon soluciones stock concentradas $100 \mathrm{X}$, se almacenaron a $-20^{\circ} \mathrm{C}$ añadiéndose posteriormente al medio antes de ajustar el pH.

4. La zeatina se añadió estéril por microfiltración en cabina de flujo, tras la esterilización del medio de cultivo a razón de $1 \mathrm{mg} / \mathrm{l}$.

\subsubsection{Evaluación del nivel de ploidía en la generación $T_{1}$ de plantas END1::barnasa de tomate (cv. Micro-Tom)}

El nivel de ploidía se analizó mediante citometría de flujo, utilizando para el aislamiento de núcleos hojas procedentes de transformantes primarios cultivados en medio de enraizamiento libre de antibiótico. El tejido de aproximadamente $1 \mathrm{~cm}^{2}$ se colocó en una placa Petri de 50 $\mathrm{mm}$ de diámetro, a la que se añadió $200 \mu \mathrm{l}$ de tampón de extracción de núcleos (Partec) y se troceó con una cuchilla. Una vez troceado, el suspendido resultante se pasó a través de una malla de nylon de $50 \mu \mathrm{l}$ (Nybolt), y se añadieron $800 \mu \mathrm{l}$ de una solución colorante que contenía 1mg/l de DAPI (4,6-diamino-2.phenyl-indole), consiguiendo así la tinción fluorescente del DNA. EI DNA de los núcleos aislados se midió utilizando un citómetro de flujo Partec PAS-II, provisto de una lámpara de mercurio. El resultado aparece trazado sobre una escala semilogarítmica, en la que el histograma que alcanza desde $2 \mathrm{C}$ a $32 \mathrm{C}$ se distribuye a lo largo del eje de abcisas. Para calibrarlo se utilizó el pico $2 \mathrm{C}$ de núcleos de hojas jóvenes de plántulas de tomate diploides cultivadas in vitro.

\subsection{ANÁLISIS DE LA GERMINACIÓN Y VIABILIDAD DE LOS GRANOS DE POLEN DE PLANTAS DE TOMATE (cv. MICRO-TOM) END1::barnasa}

\subsection{Ensayo de germinación del polen in vitro}

Para realizar el ensayo de germinación de los granos de polen de plantas transgénicas de tomate (cv. Micro-Tom), se llevó a cabo el siguiente procedimiento:

Se preparó el medio líquido de germinación del polen (sacarosa $0.292 \mathrm{M}$, $\mathrm{Ca}\left(\mathrm{NO}_{3}\right)_{2} 1.27$ $\left.\mathrm{mM}, \mathrm{H}_{3} \mathrm{BO}_{3} 1.62 \mathrm{mM}, \mathrm{KNO}_{3} 1 \mathrm{mM}, \mathrm{KH}_{2} \mathrm{PO}_{4} 0.1 \mathrm{mM}\right)$. Se añadió agarosa al $0.5 \%$ y se fundió en el microondas. Con una pipeta se distribuyó uniformemente sobre portaobjetos de vidrio y una vez solidificado el medio se espolvoreó sobre cada porta los granos de polen correspondientes a una antera de una flor de tomate. Para cada planta se realizó este proceso por triplicado.

Los portaobjetos se incubaron en oscuridad a una temperatura de $25{ }^{\circ} \mathrm{C}$ durante 2 horas tras las cuales se procedió al conteo de los granos de polen en un microscopio invertido de contraste de fases (Nikon Diaphot). Se consideró que un grano de polen ha germinado 
cuando el tamaño de su tubo polínico ha alcanzado un tamaño mayor o igual al diámetro del grano. Debido a la variabilidad de concentración de granos de polen encontrada en cada porta, se utilizaron diferentes técnicas de recuento para cada caso.

En el caso de los portas que contenían los granos de polen de las plantas silvestres, se realizó el recuento seleccionando 10 campos aleatorios. A los resultados obtenidos se les calculó la media y se multiplicó por 12 y por 27 , que son el número de campos transversal y longitudinal respectivamente del área del porta.

Para los portaobjetos que contenían los granos de polen de las plantas 9l, 12b y 4s, se hizo el recuento haciendo 5 pases longitudinales. La media de estos resultados se multiplicó por 12. En el caso de la planta 14c, el recuento se realizó en el porta completo debido a la poca cantidad de polen encontrado. Los resultados se recogen en la tabla 15 del apartado 2.3.4 de Resultados.

\subsection{Análisis de la viabilidad de los granos de polen}

Para comprobar la viabilidad de los granos de polen de plantas transgénicas END1::barnasa de tomate (cv. Micro-Tom), se utilizó el método de fijación y teñido de los cromosomas con una solución de acetato de carmín.

Para ello, se presionaron las anteras de cada flor de tomate con el objetivo de que las células sufriesen una separación mecánica. El contenido de las anteras (granos de polen) fue colocado sobre un portaobjetos y fue teñido con una solución de acetato de carmín. La solución de acetato de carmín se preparó diluyendo 0’5 $\mathrm{g}$ de carmín en ácido acético glacial al $45 \%$, y fue calentada hasta bullir. Luego se diluyó $1: 1$ en glicerol al $30 \%$. Las muestras fueron observadas y fotografiadas con un microscopio óptico Eclipse 600 Nikon. 
Tabla 6. Cebadores empleados en las amplificaciones por PCR y reacciones de secuenciación llevadas a cabo en este trabajo.

\begin{tabular}{|c|c|c|c|}
\hline Cebador & Secuencia $\left(5^{\prime} \rightarrow 3^{\prime}\right)$ & DNA molde & Posición \\
\hline Ribo 1 & TAGGATCCCGACCATGGCACAGGTTATC & Fragmento barnasa - barstar & $-12 \rightarrow 15$ \\
\hline Inhi1 & GAGGATCCATGAAAAAAGCAGTCATTAAC & Fragmento barnasa - barstar & $596 \rightarrow 616$ \\
\hline Inhi 2 & GCGAGCTCTTAAGAAAGTTGATGGTGATG & Fragmento barnasa - barstar & $876 \rightarrow 847$ \\
\hline MED 1 & CGGATCCGGAAGGTTATGTTGTGAGC & Región promotora de END1 & $-6 \rightarrow-26$ \\
\hline MED 3 & AGTCGACTCACACACATCTGAATCATCCAAC & Región promotora de END1 & $-986 \rightarrow-964$ \\
\hline MED 4 & AGTCGACTGGCAGGTATAACAAGGGTGTAAG & Región promotora de END1 & $-685 \rightarrow-662$ \\
\hline MED 5 & AGTCGACGTTTGTGGCGGTTTCAACTGTC & Región promotora de END1 & $-309 \rightarrow-288$ \\
\hline Del -426 & GTCGACTGTCATTTAATATTTAACCTTTTAAC & Región promotora de END1 & $-426 \rightarrow-402$ \\
\hline Del -366 & GCTGACGCTAAGTTATCTCATCCAAAC & Región promotora de END1 & $-366 \rightarrow-347$ \\
\hline Del -336 & GTCGACGATCATTTGAAAATACCTTTTTATTTAG & Región promotora de END1 & $-336 \rightarrow-309$ \\
\hline-366 REV & GGGATCCGTTGGATGAGATAACTTAGC & Región promotora de END1 & $-347 \rightarrow-366$ \\
\hline -309Bam & GGGATCCGTTTGTGGCGGTTTCAACTG & Región promotora de END1 & $-309 \rightarrow-288$ \\
\hline$-225 R E V$ & GGGATCCCGCTTAACTGCTTCAATTTTTTG & Región promotora de END1 & $-225 \rightarrow-247$ \\
\hline Del -208 & GAGATCTGTGGATATATATTTATCTTTGTCG & Región promotora de END1 & $-208 \rightarrow-186$ \\
\hline-366 Sal I & GCGGTCGACGCTAAGTTATCTCATCCAAAC & Región promotora de END1 & $-366 \rightarrow-347$ \\
\hline MED1BgIII & GCGAGATCTGGAAGGTTATGTTGTGAGC & Región promotora de END1 & $-6 \rightarrow-25$ \\
\hline-115 REV & GCGGGATCCCTATAAAATGACGTTCTTATTT & Región promotora de END1 & $-115 \rightarrow-135$ \\
\hline$-99 \mathrm{BgI} \mathrm{II}$ & GCGAGATCTCACATATTTCATGTACACGTG & Región promotora de END1 & $-99 \rightarrow-79$ \\
\hline MED1 + & GCGGGATCCGGAAGGTTATGTTGTGAGC & Región promotora de END1 & $-6 \rightarrow-25$ \\
\hline T7 & GTAATACGACTCACTATAGGGC & pGEM- T Easy (Promega) & $3016 \rightarrow 2099$ \\
\hline SP6 & GATTTAGGTGACACTATAGAATAC & pGEM- T Easy (Promega) & $158 \rightarrow 136$ \\
\hline
\end{tabular}

La posición de los cebadores que alinean en la región 5' de END1, hacen referencia a la secuencia representada en la figura 16.

La posición de los cebadores Ribo 1, Inhi 1 e Inhi 2 aparecen representadas en la figura 17. Las secuencias en rojo y cursiva corresponden a los nucleótidos que no forman parte del DNA molde, y de ellas, las subrayadas, corresponden a las dianas de restricción introducidas para subclonar los cDNA en los plásmidos correspondientes.

Figura 16. Secuencia de la región $5^{\prime}$ ' del gen de guisante END1. Los posibles elementos reguladores dentro de esta secuencia aparecen representados en diferentes colores en función del tipo de elemento regulador. (Ver leyenda).

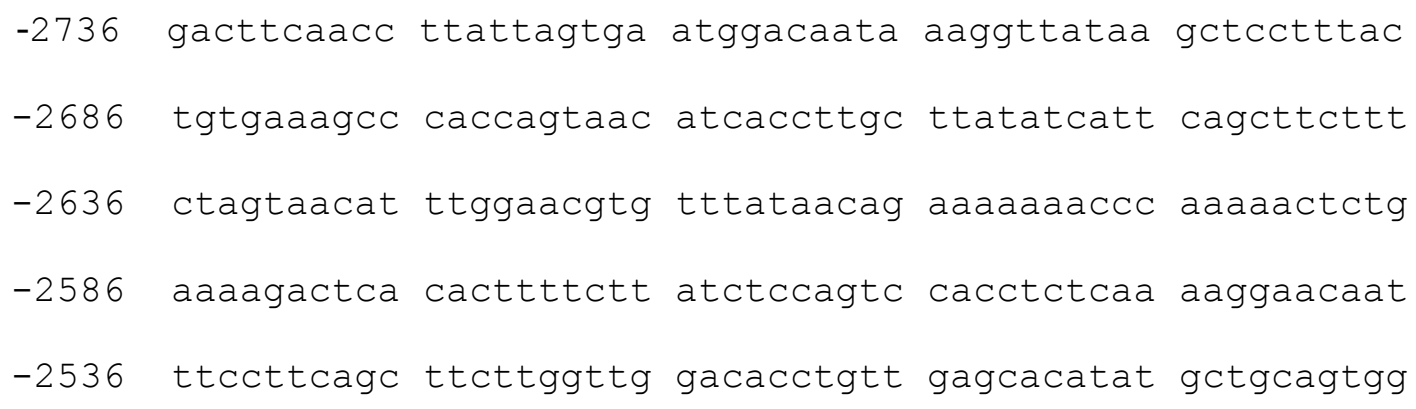


-2486 caacagtttc tccccacaaa gtgttaggaa gcttcttctc cttcagcatg

-2436 ttccttgtca tatcaagcaa agttcggttt tcaacaagac cattatgttg

-2386 aggagtatat ggatcagtca cttcatgctc aattccattc tcttacaga

-2336 acttcttgaa ctctgtagag ttatactcac ctccaccatc agttctgaga

-2386 atcttcagaa gtctgaccac tttatttctc agccttgatt atgaatttct

-2236 taaattcagc aaacacctcg tgtttgaatt ttataaggga tacccatgtc

-2186 atccttgtga actcatccat aatgacata aagtattatt ccctcctagt

-2136 gaaaggtttg taatgggcca cacacataag aatgcactac tcctaagoa

-2086 tgtttgctc tttgagctac ttttgatgaa aatggcagtc ttggttgctt

-2036 cccttcatg cacacattac atgactttt tggtttctta attgtaggaa

-1986 ttccacgtac cagttctte gaattcaaat tccctaagct cctaagttc

-1936 aaatgaccaa atcttttgtt ccacaactca ctttccttca caacacttgt

-1886 tgcgctaagg cattcagagt ctgcagtttt aacattcgcc ttgaatgttt

-1836 tactccttcc atgttctgac tccataatca acttctgata acagtcatac

-1786 agcttcaaa gaatgtcatt catggtaact ggaatccct tttcaattaa

-1736 ttgacctaca ctcatcagat tgctcttcat gccaagaacg taccaagacg

-1686 ttctgaatta atgcagattt tctattattc ataatcactc taacattccc

-1636 cattcctta gcatttagtt acttatcatc agcacatcta atcttggttt

-1586 tcttcctaga gtcaaatca accagccatt tcttatttcc agtatgatgg

-1536 tttgaacaac cagtgtccat atatcaccag tcttctatag acgcactatc

-1486 ataactagaa gccattaata gcacatgttc atcatggtgc tcagatcctt

-1436 agaatgttca attgctacaa cgatgtaatc aaactgatga gtaagagatc

-1386 taagtacct ctcaatgata ctttcctcat aagagtttc tccatgcgac

-1336 ttcatctcat ttgtgatcag aatcactcta gagatgtagt cagataactt

-1286 ctcattgttc ttcatgctta gattctcata ctgctcacgt agagactgaa

-1236 gttcacct ctacactgat gcatcactat cgtagcacca caccagtctg

-1186 tctcacacaa cctttccgt cattgaatca acgattttct taacacgtt

-1136 cacatccaca cactgatgga tgtagaacaa cgcattctga tccttcttcc 
-1086 tcatatcaca ctgagcattt ctttgcgcat ccgttgcatt ttctagaagt

-1036 gaagcataa cttcgttgat gagatcaaga acatcttgag caccaataa

-986 cacacacatc tgaatcatcc aacgattcca gttgttgtcg tcgaacaltg

-936 gnagcntggt gcacagattc acaacgatat attataantt ttgttttatg

-886 aaattaaga acaatttcc attattctta aatgtttac acactgatgt

-836 agactgcaaa aggaataaag atacaatttg ttcacaccac tcacttgcgt

-786 aaatatagt gagagttaat gagaaatact aaataccct ctaaattat

-736 gaattaattc taacalctc taatgttagt ataatccatt aadcactttg

-686 atggcaggta taacaagggt gtaagttagt gtatacatat taggctctta

-636 ttattttat attatctctg ctttcttct tcatgttctc actaatatga

-586 tattatctcc cttccctaa ttatttatat ttattagaaa aagagtttca

-536 ttttttaaa atatattacc gtaatttttc aaaaataaa atttaatat

-486 attttataaa aaattattt aataatttat ttacattaat gcataatat

-436 aataaatac tgtcatttaa tatttaacct tttacaata aattatattt

-386 atttaattca actaatataa gctaagttat ctcatccaac caattaaaa

-336 gatcatttga aataccttt ttatttagtt tgtggcggtt tcaactgtca

-286 aaaaaagga atttttacga cgatataaat ttaaccagc aaaaattga

-236 agcagttaag cgaaccaact catggtatgt ggatatattt atctttgtcg

-186 tttatatcgg attcgaatct ctataatgat gaaaattaa tatcaaactt

-136 taataagaa cgtcatttat agagccattt tgggaaacac atatttcatg

-86 tacacgtgat tcgcaattt ccaataactc tatatatagc cctcctcagt

-36 ttcatgcatt tgctcacaac ataaccttcc ttgaat

\section{LEYENDA}

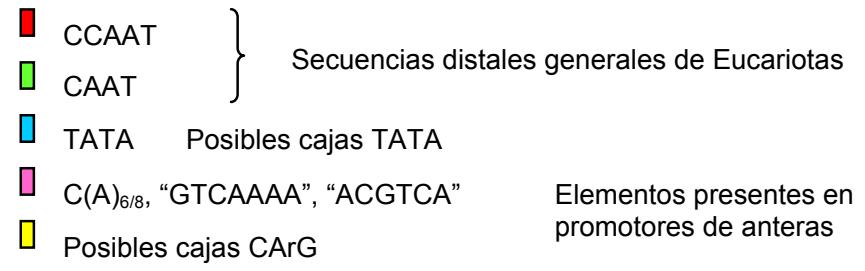




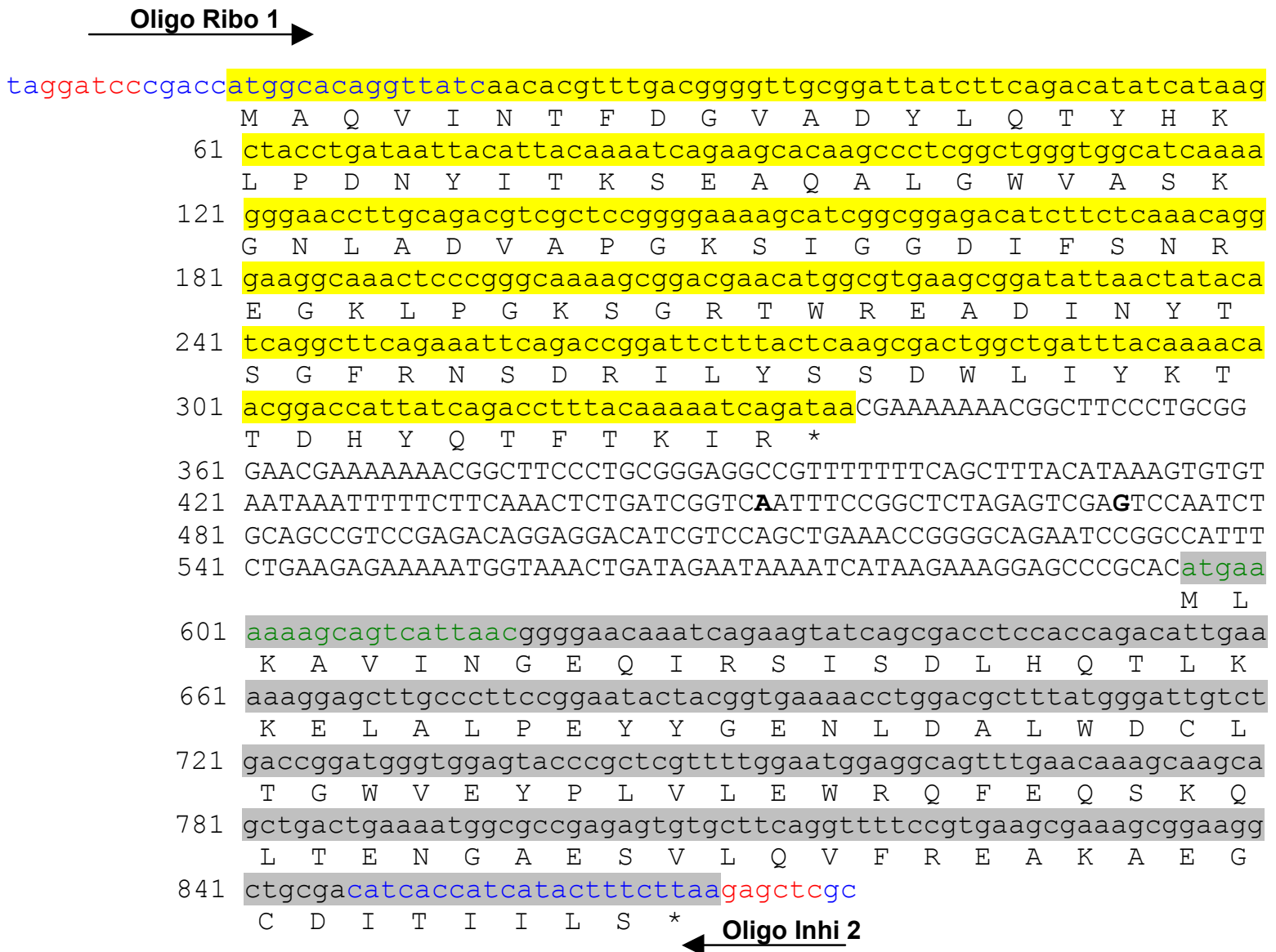

Figura 17. Secuencia del fragmento barnasa-barstar clonado en el plásmido pBluescript KS (+) (Stratagene) y secuencia de aminoácidos derivada de las secuencias codificantes de los genes barnasa y barstar.

Las secuencias codificantes de los genes barnasa y barstar están subrayadas en color amarillo y gris, respectivamente.

Los oligos Ribo1 e Inhi 2 utilizados para la amplificación del fragmento que incluía los genes barnasa y barstar, están representados en azul, y los nucleótidos que forman parte de ellos pero que corresponden con las dianas de restricción introducidas (BamHI y Sacl respectivamente), están representados en rojo. La secuencia del oligo Inhi 1 que forma parte del gen barstar está representada en verde.

La secuencia representada en esta figura a partir del codón de inicio del gen barnasa y hasta el codón de parada del gen barstar, es esencialmente la que se describe en Hartley, 1988. 

RESULTADOS 



\section{OBTENCIÓN DE PLANTAS TRANSGÉNICAS ANDROESTÉRILES DE ARABIDOPSIS THALIANA Y NICOTIANA TABACUM POR INGENIERÍA GENÉTICA UTILIZANDO EL PROMOTOR DEL GEN END1 DE GUISANTE}

La especificidad que confiere el promotor END1 para la expresión de genes foráneos en la antera (Gómez, 2000; Gómez et al., 2004), ofreció la posibilidad de utilizarlo en ensayos de ablación celular de tejidos específicos de la misma. El promotor dirigiría la expresión de un gen citotóxico en aquellos tejidos donde END1 es activo, y se comprobaría si la destrucción de éstos producía esterilidad masculina en aquellas plantas donde dicho gen se expresase.

Para comprobar si el promotor END1 puede ser una herramienta eficaz para la producción de plantas androestériles, transformamos genéticamente plantas de Arabidopsis thaliana y Nicotiana tabacum con la construcción pBI-END1::barnasa-barstar, donde la secuencia completa del promotor de END1 (-2736/-6), dirige la expresión específica del gen citotóxico barnasa a las anteras de éstas plantas.

\subsection{Androesterilidad en Arabidopsis thaliana}

\subsubsection{Transformación de plantas de Arabidopsis thaliana con la construcción pBI- END1::barnasa-barstar}

Se generaron 17 plantas transgénicas de Arabidopsis thaliana con la construcción pBIEND1::barnasa-barstar siguiendo el protocolo de infiltración al vacío descrito en el apartado 7.2 de Materiales y Métodos. De ellas, 16 fueron idénticas entre sí en cuanto a formación de flores y frutos, porte de la planta y morfología de los estambres, e idénticas a una planta silvestre en la fase de crecimiento vegetativo. La planta restante fue similar a una planta no transformada en todos los aspectos de su desarrollo.

A nivel macroscópico, el desarrollo de las plantas transgénicas y el de las plantas silvestres se mantuvo similar hasta la fase de fructificación. En ella, las plantas silvestres comenzaban a formar frutos mientras que las plantas transgénicas no producían silicuas ni semillas, y los órganos florales senescían y caían, dejando en los tallos y ramas carpelos sin fecundar. 

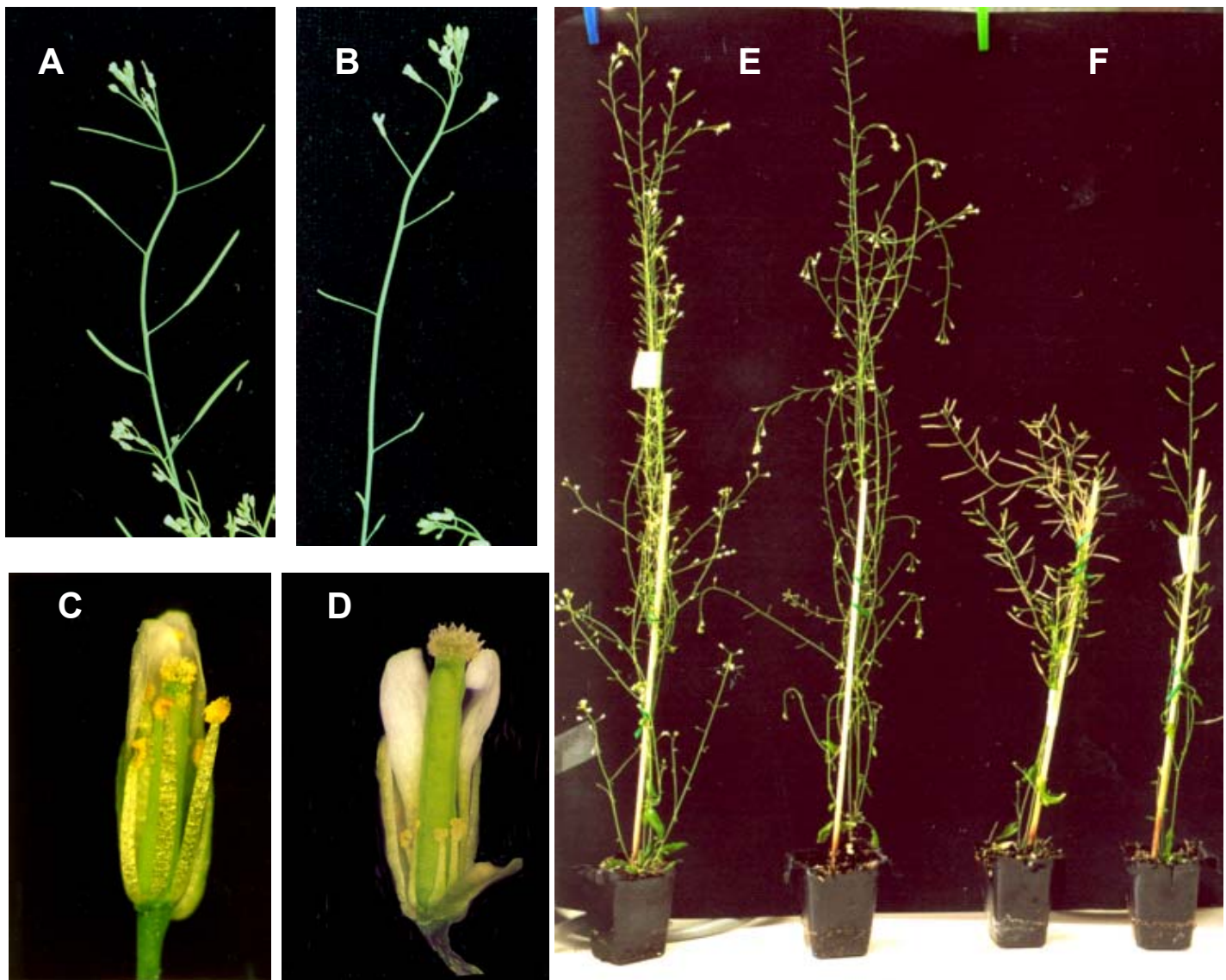

Figura 18. Fenotipo de plantas y flores de Arabidopsis transformadas con la construcción pBIEND1::barnasa-barstar. A, Silicuas en el tallo principal de una planta control de 2 semanas de desarrollo. B, Carpelos sin fecundar en el tallo principal de una planta END1::barnasa de 2 semanas de desarrollo. C, Flor de una planta control después de la antesis. Anteras dehiscentes con granos de polen en el exterior. $\mathbf{D}$, Flor de una planta transgénica END1::barnasa en un estadio de desarrollo floral aproximado al representado en C. Filamento poco alongado que alcanza la cuarta parte del tamaño de carpelo. Anteras malformadas sin granos de polen. E, Porte alcanzado por plantas END1::barnasa. F, Porte alcanzado por plantas control. En C y D se han eliminado parcialmente los pétalos de las flores para facilitar la visión de los estambres.

Los estambres de las plantas transgénicas eran diferentes a los de una planta no transformada en el tamaño del filamento y en la morfología de la antera. El filamento alcanzaba la cuarta parte del carpelo mientras que las flores silvestres en estadio similar de desarrollo tenían un filamento lo suficientemente elongado para alcanzar el estigma. En las flores transgénicas, las anteras apenas llegaban a desarrollarse, y no liberaban granos de polen como ocurre en las silvestres (Figura $18 \mathrm{C}$ y $\mathrm{D}$ ).

Sin embargo, cuando las plantas transgénicas se polinizaban con polen de anteras de plantas no transformadas, se obtenían frutos y semillas normales. Este resultado nos indica que las plantas END1::barnasa, a pesar de su androesterilidad, presentaban un sistema reproductivo femenino funcional.

El meristemo inflorescente de las plantas transgénicas seguía activo durante más tiempo que el de las plantas control. Estas plantas producían más flores y alcanzaban un porte 
aproximadamente doble que el de plantas silvestres sembradas al mismo tiempo y en las mismas condiciones (Figura $18 \mathrm{E}$ y F).

\subsubsection{Análisis por microscopía de anteras END1::barnasa de Arabidopsis thaliana}

Para estudiar con más detalle las diferencias morfológicas encontradas en las anteras de plantas androestériles con las correspondientes anteras silvestres, se llevó a cabo el análisis de las mismas mediante microscopía electrónica de barrido.

La antera silvestre muestra simetría bilateral constituida por dos pares de tecas. Los tipos celulares que conforman la epidermis de la misma presentan forma irregular y su superficie es rugosa (Figura 19 A y C).

La antera transgénica tiene forma de gancho, no se han formado las tecas y los tipos celulares encontrados en su epidermis, recuerdan a los encontrados en el filamento de una antera silvestre, de forma alargada y sin ornamentaciones (Figura 19 B y D).

Se estudiaron además las anteras transgénicas mediante microscopía óptica. Se realizaron cortes longitudinales de flores silvestres y transgénicas, incluidas en parafina, con objeto de comparar el desarrollo histológico de una antera silvestre y el alcanzado por una antera transgénica tras la acción citotóxica de la barnasa.

Para comparar el desarrollo de las flores que se muestra en la figura 20 , se han tenido en cuenta los estadios de desarrollo floral de Arabidopsis descritos por Smyth et al. (1990), en relación al desarrollo del carpelo. Así mismo, hemos utilizado los estadios del desarrollo de la antera silvestre de Arabidopsis según los estadios definidos por Sanders et al. (1999) para explicar el desarrollo de las anteras silvestres mostradas en la figura 20.

La flor silvestre representada en la figura $20 \mathrm{~A}$ se encuentra en el estadio 11 de desarrollo floral. En el carpelo aparecen las papilas estigmáticas y ya ha desarrollado el funículo del óvulo. 

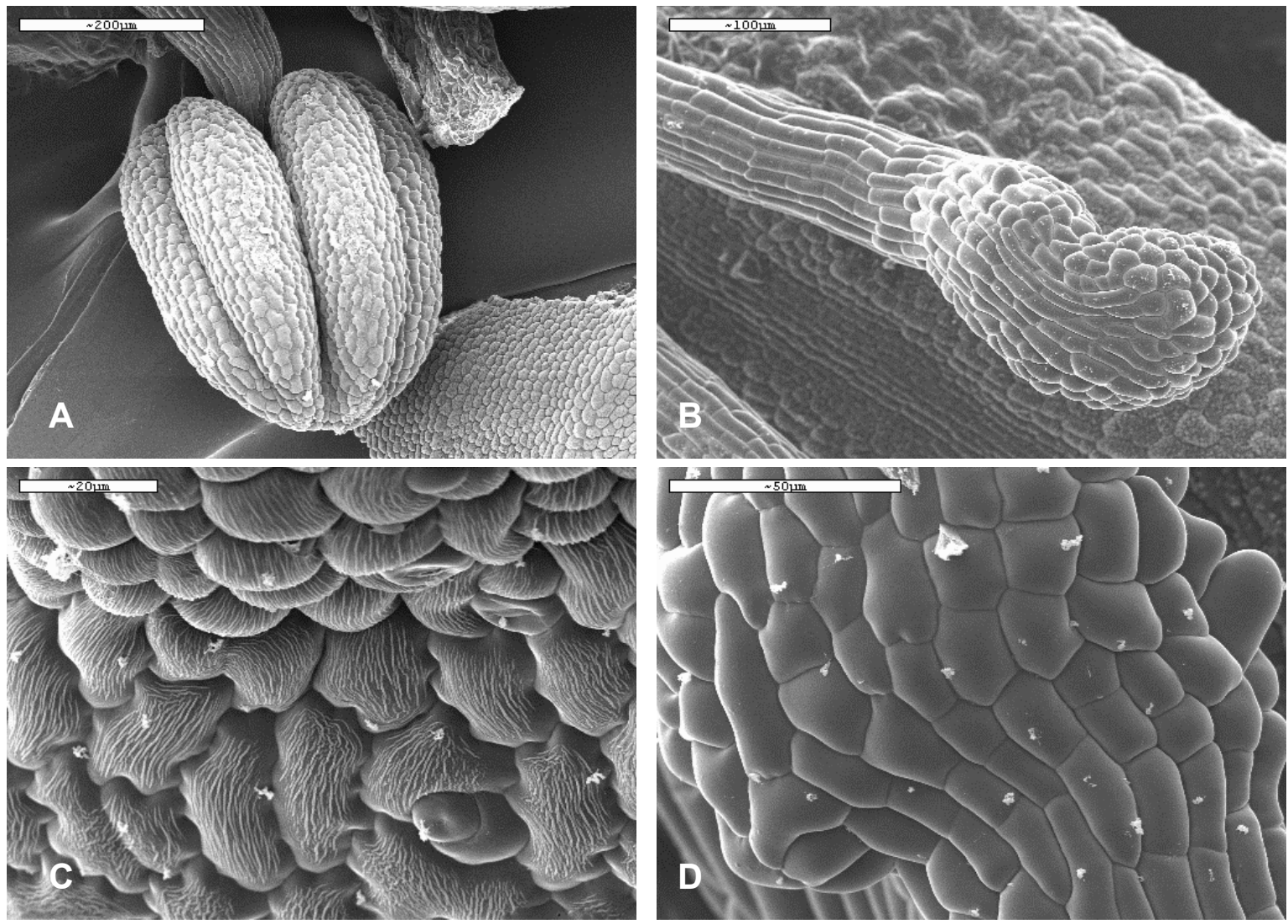

Figura 19. Análisis SEM de las características morfológicas de anteras de plantas de Arabidopsis END1::barnasa. A, Antera control mostrando los dos pares de tecas simétricas y su forma externa característica. B, Antera END1::barnasa con forma de gancho. No se han formado los 2 pares de tecas simétricas. C, Tipos celulares de la epidermis de una antera de una planta silvestre de Arabidopsis de forma irregular y superficie rugosa. D. Tipos celulares que presenta la epidermis de una antera END1::barnasa sin ornamentación exterior y de forma alargada.

La antera correspondiente presenta microsporas libres en el interior de los sacos polínicos. La flor representada en la figura $20 \mathrm{~B}$, se encuentra aproximadamente en un estadio de desarrollo 12, si tenemos en consideración que los pétalos alcanzan las 2/3 partes de la longitud del carpelo, y se aprecia en el mismo la diferenciación del tejido trasmisor. Esta flor presenta una antera con una morfología alterada. Ésta aparece con forma de gancho, y se observa un tejido amorfo en lugar de los tipos celulares reproductivos especializados o granos de polen, presentes en la antera silvestre en el estadio de desarrollo correspondiente. En la figura $20 \mathrm{D}$ podemos observar con más detalle que en el interior de los sacos polínicos aparecen restos de callosa cubriendo a posibles tetrasporas, lo que delata un retraso en el desarrollo del gametofito masculino. 


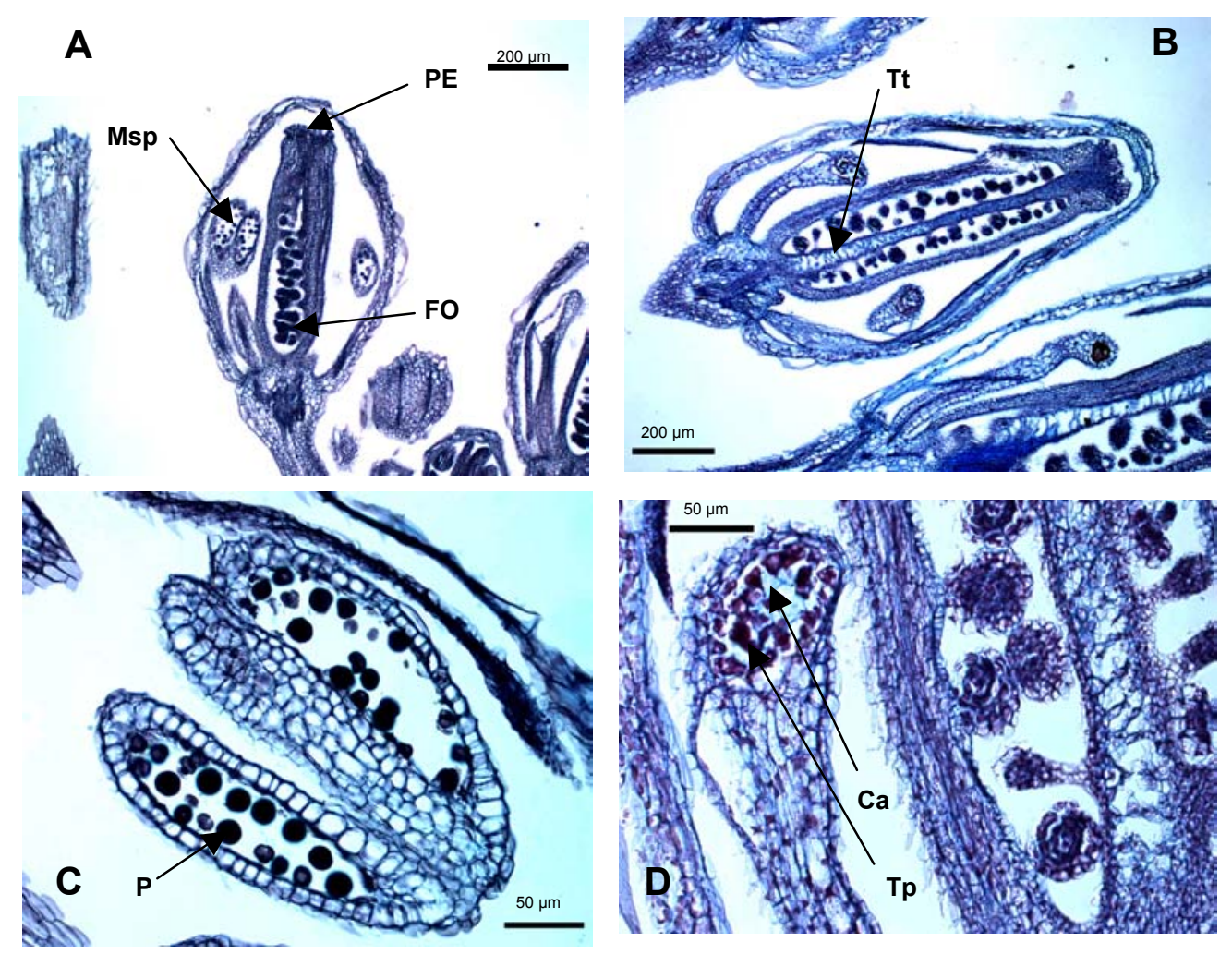

Figura 20. Secciones longitudinales de anteras silvestres y anteras END1::barnasa de Arabidopsis thaliana. A, Flor silvestre en el estadio 11 de desarrollo. Aparecen microsporas libres (Msp) en el interior de los sacos polínicos de la antera. B, Flor END1::barnasa en el estadio 12 de desarrollo. Antera con forma de gancho y aparece en el interior de los sacos polínicos una estructura amorfa en lugar de los tipos celulares reproductivos especializados. C, Antera de una flor silvestre en un estadio entre 10 y 11 de desarrollo de la antera. Se ha degradado el tapetum, aparecen granos de polen maduro $(P)$ en el interior de los sacos polínicos. D, Detalle de la antera de la flor END1::barnasa representada en $\mathrm{B}$. Muestra en detalle la antera transgénica de la flor de estadio de desarrollo floral 12. Se observan posibles tetrasporas $(\mathrm{Tp})$ rodeadas de callosa $(\mathrm{Ca})$, lo que indica un retraso en el desarrollo del gametofito masculino. PE, papilas estigmáticas; FO, Funículo del óvulo; $\mathrm{Tt}$, Tejido trasmisor.

El desarrollo de la antera silvestre representada en la figura $20 \mathrm{C}$ se corresponde al descrito para los estadios entre 10 y 11 del desarrollo de una antera de Arabidopsis. En estos estadios los tejidos no reproductivos de la antera ya se han diferenciado, ha degenerado el tapetum y en el interior de los sacos polínicos aparecen granos de polen maduro.

\subsubsection{Estudio comparativo del desarrollo de anteras silvestres y END1::barnasa de} Arabidopsis

Con el fin de analizar cuando aparecían por primera vez las diferencias a nivel histológico entre la antera transgénica y la silvestre como consecuencia de la expresión del gen citotóxico e identificar los tipos celulares que fueron afectados por el mismo, se realizó un estudio comparativo entre diferentes estadios de desarrollo de una antera silvestre y de una 
antera transgénica. Para ello hicimos secciones transversales de ambos tipos de anteras incluidas en resina en diferentes estadios de desarrollo.

En la figura 21 A-D se muestran las secciones correspondientes a cuatro estadios representativos del desarrollo de una antera silvestre de Arabidopsis según la descripción de Sanders et al. (1999).

En el panel A podemos observar un primordio estaminal constituido por células parietales primarias y esporógenas rodeadas por la epidermis (estadio 3 de desarrollo de la antera). En el panel B, (estadio 4 de desarrollo de la antera, aproximadamente) se muestra un primordio estaminal que ya ha adquirido la forma característica de una antera con sus cuatro lóbulos en el que se vislumbra la región vascular. En el interior de los sacos polínicos se observan células esporógenas que darán lugar a las células madre de las de microsporas. En la antera mostrada en el panel C (estadio 5 de desarrollo), ya están diferenciados los tipos celulares que conforman la antera: epidermis, endotecio, capa intermedia, tapetum, células madres del polen y el tejido que separa los mismos (conectivo) además del haz vascular. Las células madre de las microsporas experimentan la meiosis para generar tétradas de microsporas haploides y en el último estadio analizado, correspondiente con el estadio 9 del desarrollo de la antera, aparecen esas microsporas vacuoladas y libres rodeadas de una pared de exina. La degeneración del tapetum aún no ha comenzado.

Para analizar el desarrollo de las anteras transgénicas que se muestran en los paneles E-G de la figura 21 se utilizaron como referencia los estadios del desarrollo floral de Arabidopsis definidos por Smyth et al. (1990), de acuerdo con marcadores morfológicos del desarrollo del carpelo. Analizando éstos, se estimó el estadio de desarrollo en que deberían encontrarse las anteras (según Sanders et al. (1999) de las distintas flores analizadas.

La yema floral a la que pertenecía el primordio de antera de la figura $21 \mathrm{E}$, se encuentra en un estadio de desarrollo floral que corresponde aproximadamente al estadio 3 del desarrollo de la antera. En este estadio deberían estar diferenciadas las células parietales y deberían observarse las células esporógenas en las cuatro esquinas del primordio como se observa en el panel A de la figura 21. Sin embargo, la antera END1::barnasa muestra signos evidentes de retraso en el desarrollo ya que las células parietales y esporógenas aun no se han diferenciado. 

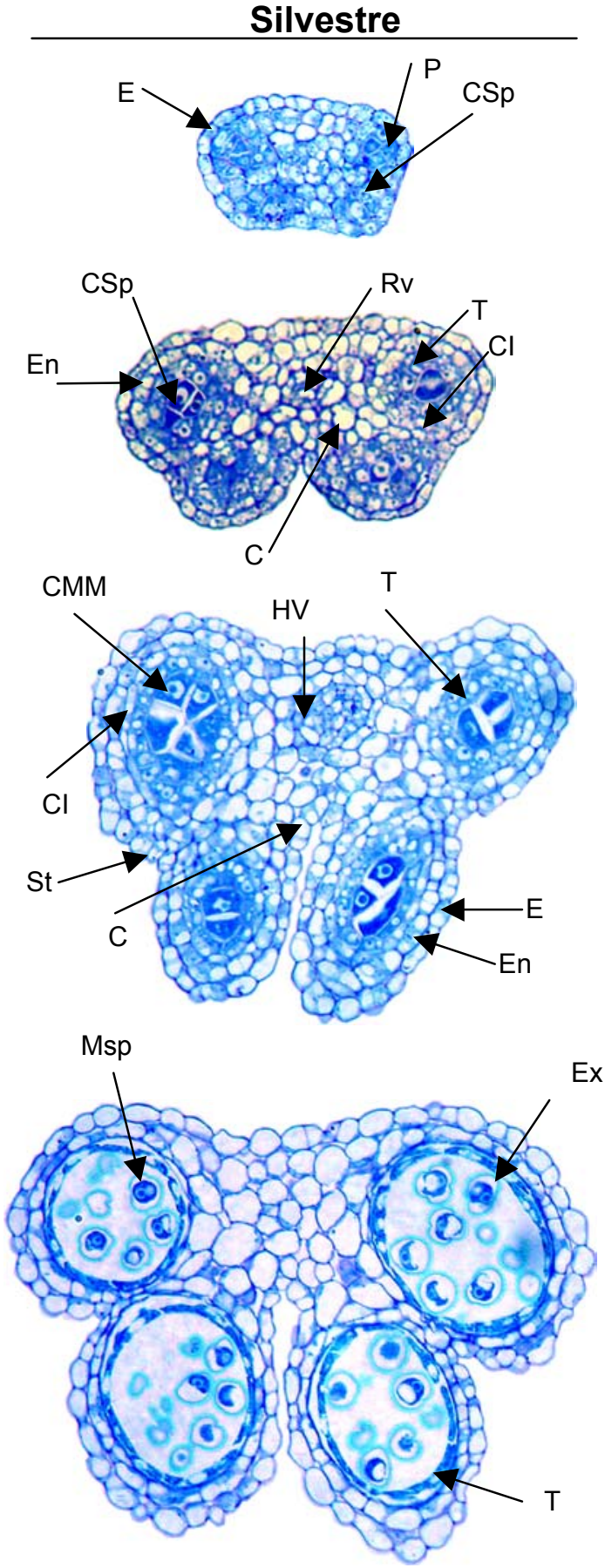

\section{END1::barnasa}

A

(Estadio 3)

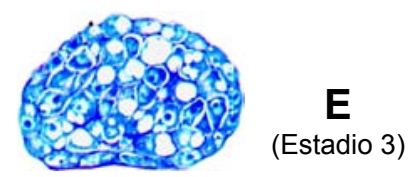

(Estadio 3)

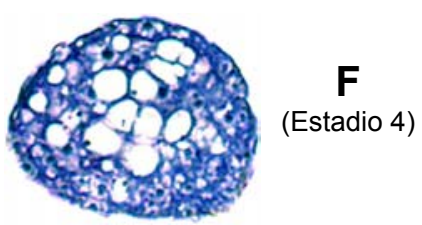

C

(Estadio 5)

\section{D}

(Estadio 9)

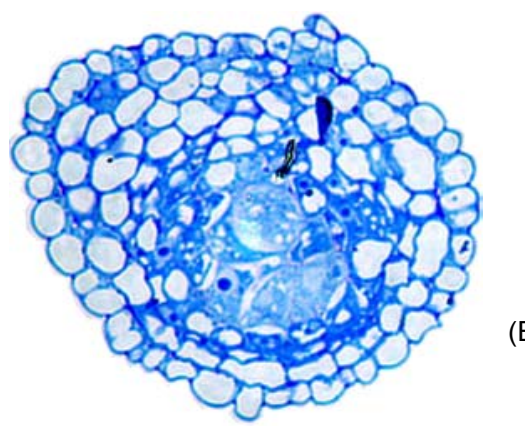

G

(Estadio 9)

\section{$50 \mu \mathrm{m}$}

Figura 21. Estudio comparativo del desarrollo de una antera silvestre de Arabidopsis thaliana y una antera transgénica END1::barnasa. A, Antera silvestre en el estadio 3 de desarrollo. Las células arquesporiales se han diferenciado en parietales $(P)$ y esporogéneas (CSp). Aparece la epidermis $(E)$ derivada de la capa $L_{1}$. B. Antera silvestre en el estadio 4 de desarrollo, aproximadamente. Empieza a observarse el tejido conectivo (C), el endotecio (En), la capa intermedia $(\mathrm{Cl})$ y el tapetum $(\mathrm{T})$. Se observan las células esporógenas $(\mathrm{CSp})$, y se inicia la región vascular (Rv). C, Antera silvestre en el estadio 5 de desarrollo. Están presentes todos los tejidos de la antera y aparecen las células madres de las microsporas (CMM). D. Antera silvestre en el estadio 9 de desarrollo. Aparecen en el interior de los sacos polínicos microsporas libres (Msp) rodeadas de 
una pared de exina (Ex) y el tapetum $(\mathrm{T})$ no ha comenzado a degenerarse. E, Antera END1::barnasa en el estadio 3 de desarrollo aproximadamente. Forma aún ovalada como la mostrada para primordios de anteras casi indiferenciados. Desorganización celular interna. $\mathbf{F}$, Antera END1::barnasa en el estadio 4 de desarrollo, aproximadamente. Al comparar esta antera con la representada en B, podemos observar diferencias morfológicas evidentes entre ambas. G, Antera END1::barnasa en el estadio 9 de desarrollo, aproximadamente. Se aprecia un único saco polínico con un retraso en el desarrollo de los tejidos reproductivos especializados para el estadio correspondiente. Morfología redondeada en lugar de la característica de una antera silvestre para ese mismo estadio. St, estomio; $\mathrm{HV}$, haz vascular.

La antera transgénica representada en la figura $21 \mathrm{~F}$ proviene de una flor cuyas anteras deberían encontrarse en el estadio de desarrollo 4, en el mismo estadio que la antera silvestre representada en la figura 21 B. Se aprecian diferencias morfológicas e histológicas entre ambas: en este estadio la antera silvestre ha alcanzado su forma externa característica y se observan casi todos los tejidos que la conforman, mientras que la antera END1::barnasa tiene forma redondeada y no se distinguen en su interior ninguno de los tipos celulares que deberían conformarla. La antera END1::barnasa representada en la figura $21 \mathrm{G}$ debería hallarse en un estadio de desarrollo aproximadamente igual a la antera que se muestra en $D$ (estadio 9). En el caso de la antera procedente de una planta transgénica, aparece una estructura de forma redondeada que contiene en su interior un tejido amorfo en lugar de los tipos característicos de la antera silvestre en el estadio 9, que serían en el caso de los tejidos reproductivos especializados, microsporas libres a punto de entrar en mitosis para dar lugar a granos de polen (Figura $21 \mathrm{D}$ ).

\subsubsection{Análisis de la segregación del transgén y de la germinación de las semillas de las líneas END1::barnasa}

Estudios anteriores realizados en nuestro laboratorio mostraron que el promotor de guisante END1, no solo era capaz de dirigir la expresión específica de un gen foráneo a las anteras de otras plantas diferentes del guisante, sino que dicha expresión no se observaba en ningún otro órgano floral ni vegetativo distinto de las anteras. Esto se comprobó mediante ensayo histoquímico de la actividad de la $\beta$-glucuronidasa (GUS) en flores, hojas, tallos, raíces y semillas germinadas de la primera generación de plantas de Arabidopsis y tabaco transformadas con el transgén END1::uidA (Gómez, 2000; Gómez et al., 2004).

En algún experimento al inicio de este trabajo parecía observarse que la frecuencia de plantas transgénicas que se obtenía tras sembrar las semillas resultantes de la fertilización de flores de plantas transgénicas T1 END1::barnasa con polen de plantas silvestres, era menor de la esperada. Entre otras, una posible explicación para esa observación podría ser que el transgén END1::barnasa mostrase una expresión inespecífica residual que afectase el desarrollo o la germinación de la semilla. 
Para analizar de un modo más riguroso esta posibilidad se estudió la germinación de cuatro líneas transgénicas distintas. Puesto que las plantas END1::barnasa son androestériles se trabajó con semillas resultantes del cruce de líneas independientes END1::barnasa con plantas del genotipo silvestre.

Tabla 7. Análisis de la germinación de plantas de Arabidopsis END1::barnasa

\begin{tabular}{cccc}
\hline Línea & $\begin{array}{c}\text { Semillas } \\
\text { sembradas }\end{array}$ & $\begin{array}{c}\text { Plantas } \\
\text { germinadas }\end{array}$ & $\begin{array}{c}\text { Porcentaje } \\
\text { germinación (\%) }\end{array}$ \\
\hline Silvestre & 58 & 55 & 94 '8 \\
$\mathrm{B}_{2}$ & 30 & 28 & 93.3 \\
$\mathrm{~B}_{8}$ & 52 & 48 & 92.0 \\
$\mathrm{~B}_{14}$ & 30 & 21 & 70.0 \\
$\mathrm{~B}_{21}$ & 30 & 29 & 96.6 \\
\hline
\end{tabular}

En la tabla 7 se observa que el porcentaje de germinación mostrado para tres de las líneas estudiadas $\left(B_{2}, B_{8}, B_{21}\right)$ es similar al porcentaje de germinación de las semillas silvestres y sólo la línea $\mathrm{B}_{14}$ muestra una disminución apreciable en el porcentaje de germinación. Estos datos no apoyan la idea de que la expresión del transgén END1::barnasa afecte al desarrollo o germinación de las semillas; al menos no en todas las líneas utilizadas en este experimento.

Este experimento se aprovechó para analizar también en esas líneas la segregación del fenotipo androestéril y así tendríamos una idea del número de loci en que el transgén se había integrado en las correspondientes plantas T1. Los datos de este análisis se muestran en la tabla 8.

Los porcentajes de plantas estériles de la descendencia de las líneas $B_{8}$ y $B_{14}$ fueron del $43,7 \%$ y del $47,6 \%$ respectivamente, ambos cercanos al $50 \%$.

Tabla 8. Análisis de la segregación del fenotipo andorestéril en plantas transgénicas de Arabidopsis.

\begin{tabular}{|c|c|c|c|c|c|c|c|c|}
\hline \multirow[t]{2}{*}{ Línea } & \multirow{2}{*}{$\begin{array}{l}N^{0} \text { Plantas } \\
\text { analizadas } \\
\text { (T) }\end{array}$} & \multicolumn{2}{|c|}{ Fenotipo } & \multirow{2}{*}{$\begin{array}{c}\text { Porcentaje } \\
(\%)^{\mathrm{c}}\end{array}$} & \multirow[t]{2}{*}{ Segregación } & \multirow{2}{*}{$\chi^{2}$} & \multirow{2}{*}{$\begin{array}{c}\text { Nivel } \\
\text { Significación } \\
\text { (P) }\end{array}$} & \multirow{2}{*}{$\begin{array}{c}\mathrm{N}^{\circ} . \\
\text { copias }\end{array}$} \\
\hline & & $E^{a}$ & $F^{b}$ & & & & & \\
\hline $\mathrm{B}_{2}$ & 28 & 4 & 24 & $14^{\prime} 0$ & $1: 1$ & $14^{\prime} 285$ & 0 & - \\
\hline $\mathrm{B}_{8}$ & 48 & 21 & 27 & $43^{\prime} 7$ & $1: 1$ & $0 ’ 750$ & 0,39 & 1 \\
\hline$B_{14}$ & 21 & 10 & 11 & $47^{\prime} 6$ & $1: 1$ & 0’048 & $0 ’ 83$ & 1 \\
\hline$B_{21}$ & 29 & 19 & 10 & $65^{\prime} 5$ & $3: 1$ & $1 ' 38$ & 0 '24 & 2 \\
\hline
\end{tabular}

${ }^{a}$ Plantas estériles obtenidas del total de plantas analizadas

b Plantas fértiles obtenidas del total de plantas analizadas

${ }^{c}$ Porcentaje de plantas estériles del total de plantas analizadas. 
Estos resultados se ajustan, aproximadamente, a los valores esperados de una relación 1:1 de plantas estériles frente a fértiles en la descendencia F1 del cruce de una planta silvestre con una planta hemicigota que contiene un transgén insertado en un único locus. Los datos de la segregación de la descendiencia de la línea $B_{21}$ sugieren insersiones del transgén en dos loci distintos (relación 3:1 plantas estériles frente a fértiles). Por último, la línea independiente $B_{2}$, muestra una frecuencia del fenotipo andorestéril baja, lo que posiblemente refleje una baja expresión del transgén en dicha línea.

\subsubsection{Eficiencia del transgén END1::barnasa en la obtención de androesterilidad}

Para evaluar la eficiencia del transgén END1::barnasa para eliminar la producción de frutos en plantas transgénicas, cultivamos descendientes del cruce de líneas independientes END1::barnasa con plantas silvestres. En cada una de las plantas androestériles resultantes de dichos cruces se contabilizó el número de silicuas formadas para un determinado número de posiciones florales (Tabla 9 ).

Por otra parte, con el fin de evaluar si cambios en las condiciones ambientales, tales como el fotoperiodo, tenían algún efecto en la actividad del transgén END1::barnasa, realizamos dos ensayos en paralelo, uno bajo condiciones de cultivo de día largo (DL, $16 \mathrm{~h}$ de luz, 8h de oscuridad) y otro bajo condiciones de día corto (DC, 8h de luz, $16 \mathrm{~h}$ de oscuridad).

Tabla 9. Eficiencia de la construcción END1::barnasa para inducir androesterilidad en plantas END1::barnasa crecidas en día largo (DL).

\begin{tabular}{crrrc}
\hline Línea & Plantas $^{\mathbf{a}}$ & $\begin{array}{c}\text { DIA LARGO } \\
\text { Posiciones }^{\text {florales }} \mathbf{b}^{-}\end{array}$ & Silicuas $^{\mathbf{c}}$ & Porcentaje (\%) $^{\mathbf{d}}$ \\
\hline Silvestre & 4 & 289 & 283 & $97^{\prime} 9$ \\
$\mathbf{B}_{\mathbf{8}}$ & 10 & 1659 & 37 & $2{ }^{\prime} 20$ \\
$\mathbf{B}_{14}$ & 4 & 1040 & 9 & 0,86 \\
$\mathbf{B}_{\mathbf{2}}$ & 3 & 620 & 0 & 0 \\
$\mathbf{B}_{\mathbf{2 1}}$ & 3 & 511 & 0 & 0 \\
\hline
\end{tabular}

a Número de plantas analizadas para cada caso. Las plantas transgénicas analizadas son descendientes del cruce de líneas independientes END1::barnasa con plantas silvestres.

${ }^{b}$ Total de posiciones florales de las plantas analizadas.

c Silicuas formadas en cada una de las plantas analizadas.

d Porcentaje de formación de silicuas en las posiciones florales contadas.

En DL, el 97 '9 \% de las flores de las plantas de Arabidopsis silvestres analizadas fue capaz de formar fruto, mientras que en plantas descendientes de la línea $B_{8}$ sólo el 2'2\% de las flores produjo fruto. En el caso de la descendencia analizada para la línea independiente 
$\mathrm{B}_{14}$, se produjo formación de silicuas en el 0’86\% de las posiciones florales contadas (Tabla 9). Las plantas descendientes de las líneas $B_{2}$ y $B_{21}$.no mostraron formación de silicuas en ninguna posición floral (Tabla 9).

En día corto (DC), las plantas silvestres formaron fruto en el $96^{\prime} 1 \%$ de sus posiciones florales, mientras que la descendencia de las líneas independientes $B_{8}$ y $B_{14}$ mostraron un porcentaje de formación de silicuas del 0’38 \% y el 0\% respectivamente (Tabla 10).

Analizando los resultados, encontramos ligeras diferencias en la formación de silicuas dentro de las mismas líneas independientes cuando se cultivan a diferentes condiciones de fotoperiodo.

La formación de silicuas por las plantas de las líneas $B_{8}$ y $B_{14}$ en ambas condiciones de fotoperiodo podría deberse a una expresión insuficiente del gen barnasa. Así mismo, la formación de algunas de estas silicuas también podría deberse a polinización con plantas vecinas.

Tabla 10. Eficiencia de la construcción END1::barnasa para inducir androesterilidad en plantas END1::barnasa crecidas en día corto (DC).

\begin{tabular}{|c|c|c|c|c|}
\hline \multicolumn{5}{|c|}{ DIA CORTO } \\
\hline Línea & Plantas $^{a}$ & $\begin{array}{c}\text { Posiciones } \\
\text { florales }\end{array}$ & Silicuas $^{c}$ & Porcentaje (\%) ${ }^{d}$ \\
\hline Silvestre & 4 & 543 & 522 & $96 \prime 1$ \\
\hline $\mathrm{B}_{8}$ & 6 & 798 & 3 & 0,38 \\
\hline$B_{14}$ & 5 & 441 & 0 & 0'00 \\
\hline
\end{tabular}

a Número de plantas analizadas para cada caso. Las plantas transgénicas analizadas son descendientes del cruce de líneas independientes END1::barnasa con plantas silvestres.

${ }^{\mathbf{b}}$ La suma del número de posiciones florales contadas en cada una de las plantas analizadas.

c La suma del número de silicuas formadas en cada una de las plantas analizadas.

d Porcentaje de formación de silicuas en las posiciones florales contadas.

\subsubsection{Restauración de la fertilidad en plantas de Arabidopsis END1::barnasa}

Los resultados descritos hasta el momento muestran que la expresión del transgén END1::barnasa destruye determinadas células y tejidos en las anteras de las plantas transformadas. Esto previene la formación del polen por lo que las plantas obtenidas son androestériles.

El transgén END1::barnasa contiene la secuencia codificante de la ribonucleasa extracelular de Bacillus amyloliquefaciens barnasa para la cual existe también en el genoma de dicho microorganismo un inhibidor específico denominado barstar .

Con objeto de estudiar si es posible restaurar la fertilidad de las plantas de Arabidopsis END1::barnasa mediante la expresión en las mismas del inhibidor barstar, se generó la 
construcción END1::barstar (Materiales y Métodos, apartado 7.1.2) en la cual la secuencia codificante del inhibidor se encuentra fusionada a la secuencia completa del promotor de END1 (-2736/-6). Se transformaron plantas de Arabidopsis thaliana con dicha construcción y se seleccionaron plantas homocigotas para la mismas (Materiales y Métodos, apartados 7.2 y 7.2.1).

Para comprobar si la expresión del transgén END1::barstar en plantas END1::barnasa era capaz de inhibir la acción destructiva del gen citotóxico en las anteras, realizamos el cruce entre una planta hemicigota de la línea END1::barnasa ${ }_{8}$ con una planta homocigota de la línea END1::barstar 14. (Figura 22).

END1::barnasa

\section{Bbaa}

(parental femenino, plantas androestériles)
END1::barstar

bbAA

(parental masculino, plantas fértiles)

\begin{tabular}{|c|c|c|c|}
\hline \multirow{3}{*}{$\begin{array}{r}\text { Gametos } \\
\text { femeninos }\end{array}$} & & bA & Gametos masculinos \\
\hline & $\mathrm{Ba}$ & BbaA & \multirow{2}{*}{ Descendencia } \\
\hline & ba & bbaA & \\
\hline
\end{tabular}

Figura 22. Representación esquemática del experimento de la restauración de la fertilidad masculina por el cruce entre plantas homocigotas END1::barstar y plantas hemicigotas END1::barnasa. Todas las plantas de la descendencia heredan una copia del transgén END1::barstar (A) y por tanto podrían ser fértiles. B: transgén END1::barnasa, b: ausencia del transgén END1::barnasa, A: transgén END1::barstar, a: ausencia del transgén END1::barstar, $\mathbf{A}$ y $\mathbf{B}$ son alelos dominantes.

Del cruce entre la planta de la línea END1::barnasa \& y la planta homocigota END1:: barstar $_{14}$, se obtuvieron 35 semillas que se sembraron directamente en tierra de las que germinaron 32 semillas (Tabla 11). A las plantas resultantes se les realizó un análisis fenotípico que consistió en medir la fertilidad teniendo en cuenta el número y el aspecto de las silicuas en las mismas. Se estableció una clasificación que permitió dividir la población de plantas en cuatro clases según el "grado de fertilidad" que mostraban. Las plantas clasificadas con grado 1 se corresponden con plantas casi estériles; estas plantas desarrollaron silicuas en aproximadamente $15-20 \%$ de sus posiciones florales pero dichas silicuas eran pequeñas y de un grosor menor que las silicuas silvestres. Las plantas que se clasificaron como grado 2 mostraban una mejoría en cuanto a fenotipo de los frutos que eran algo más parecidos a los silvestres aunque la cantidad de silicuas por planta no tenía un aumento considerable al compararlas con las de grado 1. 
Tabla 11. Análisis del porcentaje de germinación y fertilidad de plantas END1::barnasa END1::barstar resultantes del cruce END1::barnasa ${ }_{8}^{a} \times$ END1::barstar $_{14} \mathrm{~b}$.

\begin{tabular}{|c|c|c|c|c|c|}
\hline $\begin{array}{c}\text { Semillas } \\
\text { sembradas }\end{array}$ & $\begin{array}{c}\text { Plantas } \\
\text { germinadas }\end{array}$ & $\begin{array}{c}\text { Porcentaje de } \\
\text { germinación }\end{array}$ & $\begin{array}{c}\text { Plantas } \\
\text { fértiles }\end{array}$ & $\begin{array}{c}\text { Plantas fertilidad } \\
\text { disminuida }\end{array}$ & Porcentaje \\
\hline 35 & 32 & 91 '4 & 17 & 15 & 53 '1 \\
\hline
\end{tabular}

a La planta END1::barnasa 8 contenía la inserción de dicho transgén en un solo locus y era hemicigota para el mismo.

b La planta END1::barstar 14 contenía la inserción de dicho transgén en un solo locus y era homicigota para el mismo.

c Se consideraron plantas completamente fértiles a aquellas que fueron clasificadas con grado de fertilidad 4.

d Se consideraron plantas con fertilidad disminuida a aquellas que fueron clasificadas con los grados de fertilidad de 1-3.

e Porcentaje de plantas fértiles del total de plantas germinadas.

El grado 3 de fertilidad se correspondía con plantas donde la cantidad de silicuas aumentaba notablemente (se formaban silicuas en aproximadamente el $40 \%$ de sus posiciones florales) y el fenotipo de la mayoría de las mismas era similar a las de plantas silvestres. El grado 4 mostraba fenotipo silvestre en cuanto a cantidad de silicuas por planta y aspecto de las mismas.

La Tabla 12 muestra la clasificación según el grado de fertilidad para cada planta descendiente del cruce entre plantas hemicigotas END1::barnasa \& y plantas homocigotas END1:: barstar $_{14}$. También se muestra un recuento del número de silicuas formadas para 6 de estas plantas.

Las plantas $\mathrm{N}^{0} 19$ y $\mathrm{N}^{0} 1$, representantes del grado de fertilidad 1, formaron silicuas en el 16 ' $4 \%$ y en el $19 ' 1 \%$ de sus posiciones florales, respectivamente

Un ejemplo del grado 2 de fertilidad son las plantas $\mathrm{N}^{\circ} 14$ y $\mathrm{N}^{\circ} 18$, donde la formación de silicuas asciende al $22{ }^{\prime} 3 \%$ y 20 '3\%, respectivamente. La planta $\mathrm{N}^{\circ} 6$, que representa el grado de fertilidad 3, mostró un 41 ' $6 \%$ de formación de silicuas en sus posiciones florales.

Finalmente, en la planta $N^{\circ} 3$ todas las flores fueron capaces de formar frutos normales.

Si la expresión del inhibidor barstar en las transgénicas END1::barnasa anulase completamente la actividad del gen citotóxico, se esperaría que todas las plantas resultantes del cruce fueran fértiles. Sin embargo, en la Tabla 11 podemos observar que sólo 17 de las 32 plantas resultantes muestran una fertilidad completa mientras que el resto tiene una fertilidad disminuida. El porcentaje de plantas completamente fértiles es de un $53,1 \%$, valor que se corresponde aproximadamente al esperado en ausencia de polinización.

Aunque la expresión del transgén END1::barstar en plantas END1::barnasa, no fue capaz de restaurar completamente la fertilidad de las mismas, la acción citotóxica que provocaba la ribonucleasa se hallaba claramente disminuida. La figura 23 muestra el efecto 
Tabla 12. Análisis del grado de fertilidad de plantas descendientes del cruce entre una planta hemicigota de la línea END1::barnasa 8 y una planta homocigota de la línea END1::barstar ${ }_{14}$.

\begin{tabular}{|c|c|c|c|c|}
\hline Plantas $^{a}$ & $\begin{array}{l}\text { Grado de } \\
\text { Fertilidad }\end{array}$ & $\begin{array}{l}\text { Posiciones } \\
\text { florales }\end{array}$ & Silicuas $^{d}$ & Porcentaje (\%) $^{\mathrm{e}}$ \\
\hline 1 & 1 & 68 & 13 & $19^{\prime} 1$ \\
\hline 2 & 4 & & & \\
\hline 3 & 4 & 79 & 79 & 100 \\
\hline 4 & 3 & & & \\
\hline 5 & 3 & 36 & 15 & $41^{\prime} 6$ \\
\hline 6 & 2 & & & \\
\hline 7 & 4 & & & \\
\hline 8 & 1 & & & \\
\hline 9 & 4 & & & \\
\hline 10 & 4 & & & \\
\hline 11 & 4 & & & \\
\hline 12 & 2 & & & \\
\hline 13 & 4 & & & \\
\hline 14 & 2 & 157 & 35 & $22^{\prime} 3$ \\
\hline 15 & 4 & & & \\
\hline 16 & 4 & & & \\
\hline 17 & 3 & & & \\
\hline 18 & 2 & 261 & 53 & $20^{\prime} 3$ \\
\hline 19 & 1 & 73 & 12 & $16^{\prime} 4$ \\
\hline 20 & 4 & & & \\
\hline 21 & 4 & & & \\
\hline 22 & 4 & & & \\
\hline 23 & 4 & & & \\
\hline 24 & 4 & & & \\
\hline 25 & 4 & & & \\
\hline 26 & 4 & & & \\
\hline 27 & 3 & & & \\
\hline 28 & 4 & & & \\
\hline 29 & 3 & & & \\
\hline 30 & 3 & & & \\
\hline 31 & 1 & & & \\
\hline 32 & 3 & & & \\
\hline
\end{tabular}

\footnotetext{
${ }^{\mathrm{a}}$ Esta columna muestra cada planta analizada descendiente del cruce entre una planta hemicigota de la línea END1:: barnasa $_{8}$ y una planta homocigota de la línea END1::barstar ${ }_{14}$

${ }^{b}$ Clasificación de las plantas según el grado de fertilidad.

${ }^{\mathrm{c}}$ Número de posiciones florales contadas en cada una de las plantas.

${ }^{d}$ Número de silicuas formadas en las posiciones florales contadas.

${ }^{\text {e }}$ Porcentaje de silicuas formadas en relación al número de posiciones florales contadas.
} 
de la expresión del inhibidor barstar en el fenotipo de los estambres en flores de plantas END1::barnasa-END1::barstar con fertilidad parcialmente restaurada. Se puede ver que en dichas flores el filamento ha elongado casi hasta el estigma del carpelo, y las anteras muestran un fenotipo más parecido al que muestran anteras silvestres, que al mostrado por las anteras de la planta END1::barnasa usada como parental femenino en el cruce (Figura $23 \mathrm{~B})$.
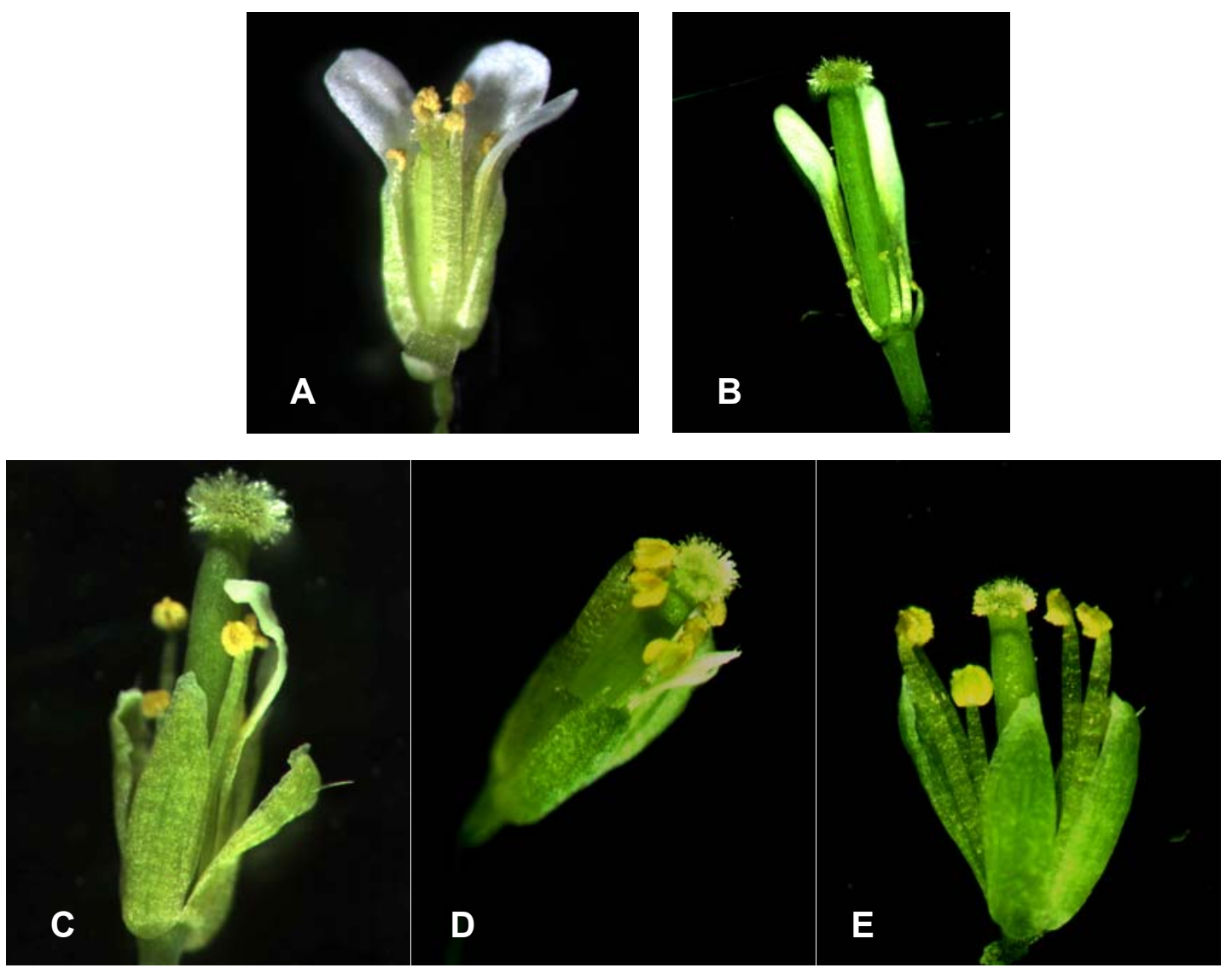

Figura 23. Fenotipo de flores de plantas transgénicas END1::barnasa-END1::barstar. A, Flor de una planta transgénica END1::barstar. Anteras dehiscentes de fenotipo silvestre. B, Fenotipo de las flores de la línea independiente END1:: barnasa $_{8}$, usadas como parental femenino. Anteras con el fenotipo estéril mostrado para plantas transgénicas END1::barnasa en Arabidopsis thaliana. C, Fenotipo de flores de la planta $\mathrm{N}^{\circ} 14$ de la descendencia del cruce entre plantas END1::barnasa ${ }_{8} \times$ END1::barstar ${ }_{14}$. D, Fenotipo de flores de la planta $\mathrm{N}^{\circ} 5$ de la descendencia del cruce entre plantas END1::barnasa 8 × END1::barstar ${ }_{14}$. E, Fenotipo de flores de la planta $\mathrm{N}^{\circ} 19$ de la descendencia del cruce entre plantas END1::barnasa 8 × END1:: barstar 14. 


\subsection{Androesterilidad en Nicotiana tabacum}

\subsubsection{Transformación de plantas de Nicotiana tabacum con la construcción pBI- END1::barnasa-barstar}

Como resultado de la transformación de tabaco con la construcción pBI-END1::barnasabarstar, se generaron tres plantas transgénicas primarias $\left(T_{1}\right)$ : TAB 1, TAB 2 y TAB 3.

A diferencia de los resultados obtenidos en Arabidopsis, donde las plantas transgénicas de la generación $T_{1}$ fueron esencialmente idénticas en cuanto a morfología de los estambres y formación de flores y frutos, las plantas de tabaco transgénicas no eran tan similares en estos aspectos.

En las flores adultas (estadio de desarrollo floral 12, según los definidos por Koltunow et al. (1990) de la planta TAB 1, los estambres tenían un filamento más corto, de aproximadamente las 2/3 partes de la longitud del carpelo. Las anteras de color marrón oscuro estaban colapsadas y su forma parecía una punta de flecha (Figura 24 C). Una flor de una planta control no transformada en este mismo estadio de desarrollo tiene estambres que han elongado lo suficiente para que el polen liberado de las anteras dehiscentes se deposite en el estigma del carpelo y ocurra la polinización (Figura 24 D). Estas diferencias en el fenotipo de las anteras son evidentes desde estadios tempranos del desarrollo floral. A la derecha de la figura 24 A se observa una yema floral de la planta transgénica TAB 1 donde el cáliz se abre ligeramente, y las anteras difieren de las de una planta control (Figura $24 \mathrm{~A}$, izquierda). Se observaba un ligero colapso de los tejidos, por lo que la forma externa adquirida se va pareciendo a una punta de flecha. Mientras que cada flor de la planta control formaba un fruto, la planta transgénica TAB1 mostraba flores estériles que nunca desarrollaron frutos (Figura 25 A y B). Aunque no se observaron diferencias marcadas, como en Arabidopsis, entre el porte alcanzado por la misma y el de plantas control no transformadas, pudimos observar que la floración de la planta transgénica TAB 1 fue continuada durante un período de 24 meses. Las flores senescentes caían de la planta, pero en sus ramas laterales aparecían nuevas yemas florales que mantenían la planta con flores. La planta transgénica TAB1 fue androestéril, pero su pistilo era fértil al obtenerse cápsulas y semillas normales de la polinización de ésta con polen procedente de una planta no transformada. 

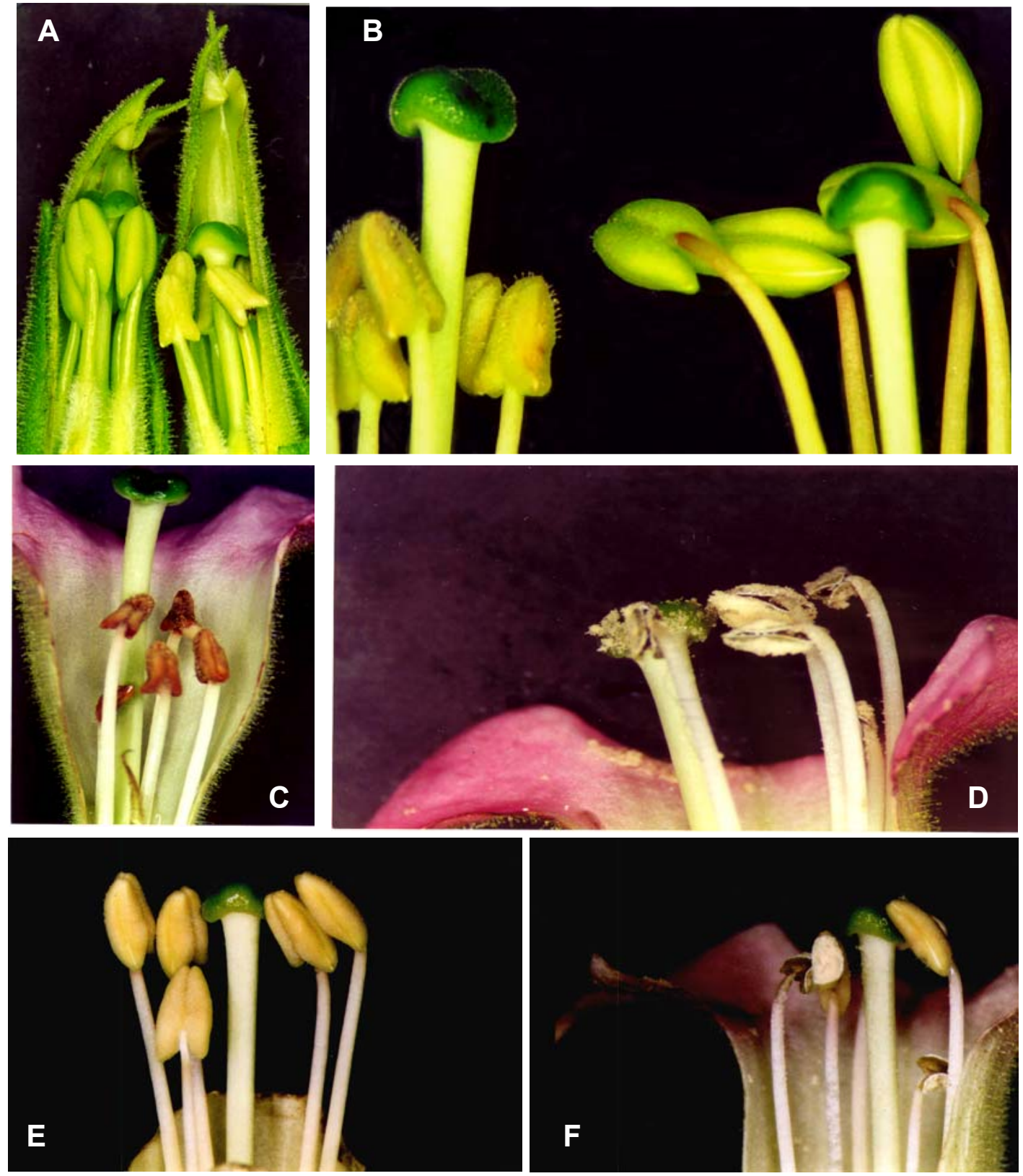

Figura 24. Comparación de flores silvestres y flores END1::barnasa de Nicotiana tabacum. A, Izda, yema floral de una flor control en estadio de desarrollo 4 aproximadamente, según Koltunow et al. (1990) y Dcha, yema de una flor de la planta TAB 1 en un estadio de desarrollo similar. Las anteras de la flor transgénica están colapsadas y muestran forma de punta de flecha. B, Izda, anteras de una flor de la planta TAB1, la cual se encontraba en un estadio de desarrollo floral entre 8 y 9 aproximadamente. A la derecha, anteras de una flor control de estadio de desarrollo floral similar. C, Anteras de color marrón, más colapsadas que las de la figura B (izquierda) y con aspecto de punta de flecha. Pertenecen a una flor de la planta TAB 1 en estadio de desarrollo floral 12. D, Se observan anteras dehiscentes con granos de polen sobre el estigma del carpelo de una flor de una planta control en un estadio de desarrollo floral 12. E, Anteras de la planta TAB 2 de estadio similar al representado en $B$. La malformación en las mismas es menos severa. F, Anteras de la planta TAB 2 de una flor en estadio de desarrollo floral similar al representado en $\mathrm{D}$. 

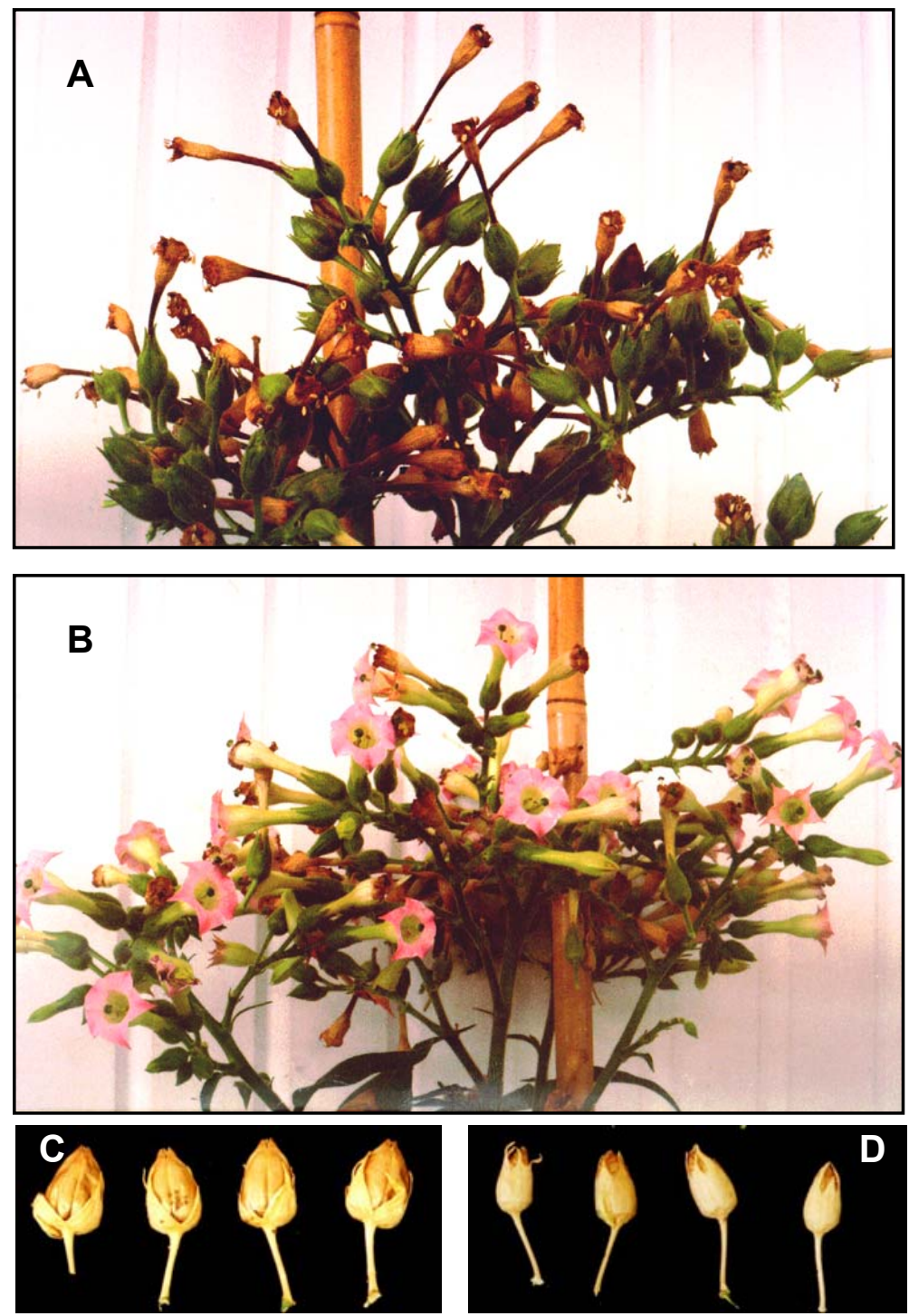

Figura 25. Fenotipo de flores y frutos de plantas END1::barnasa en Nicotiana tabacum.

A, Formación de frutos en el ápice de una planta control de tabaco. B. Flores estériles en el ápice de la planta de tabaco TAB 1 en un estadio de desarrollo similar al de la planta control representada en A. Se observa la ausencia general de frutos y proliferación de flores, cuando en la planta control, éstas han entrado en dehiscencia. C, Frutos de una planta de tabaco control. D, Frutos desarrollados por la planta de tabaco TAB 2 (fenotipo intermedio). Son de menor tamaño y con un número de semillas 3 veces menor que las que presentan los frutos de una planta control.

La planta transgénica $T A B 2$, tenía flores con estambres de fenotipo menos severo que el de la planta TAB 1. Sus filamentos elongaban casi hasta el estigma, y las anteras mostraban un ligero estrechamiento al compararlas con anteras de flores silvestres. El color de las anteras transgénicas no llegaba a ser marrón oscuro como el de la planta TAB 1 , pero mostraba diferencias con el de una antera de una planta no transformada (Figura $24 \mathrm{E}$, F). Esta planta formó fruto en aproximadamente la mitad de sus posiciones florales. Éstos eran más pequeños y tenían un número de semillas 3 veces menor que los de una planta de tabaco no transformada (Figura $25 \mathrm{C}$ y D). 
La planta transgénica TAB 3 fue idéntica a una planta control en todos los aspectos, incluso en la morfología de los estambres y en la formación de flores y frutos. El único dato que indicaba que la planta TAB 3 era transgénica, era que $3 / 4$ partes de sus semillas mostraba resistencia a kanamicina. No obstante, esta línea transgénica no se estudió con detalle y carecemos de datos para concluir si la ausencia de fenotipo androestéril se debe a una baja expresión del transgén END1::barnasa o a algún artefacto tal como que la línea no contenga el transgén END1::barnasa completo.

\subsubsection{Análisis por microscopía de anteras END1::barnasa de Nicotiana tabacum}

Las anteras de la planta END1::barnasa TAB 1 se estudiaron externa e internamente por microscopía electrónica de barrido. Se realizó el mismo tipo de estudio para anteras de plantas no transformadas con el objetivo de analizar la morfología externa, los tipos celulares y la presencia de los tejidos reproductivos especializados en los sacos polínicos en ambos tipos de anteras (Figura 26). Una antera de tabaco silvestre tiene dos tecas bilateralmente simétricas y adopta una forma característica de pala (Goldberg et al., 1993) (Figura 26 A). A partir del estadio 3 de desarrollo aparecen granos de polen en el interior de los sacos polínicos (Figura 29 C), y la epidermis tiene células cónicas con ornamentación (Figura $26 \mathrm{~B}$ ). La antera END1::barnasa tiene también simetría bilateral pero muestra diferencias con la de una antera de una planta no transformada. Los tejidos que conforman su arquitectura se han colapsado por lo que ha adoptado una forma más estrecha, parecida a una punta de flecha (Figura 26 D). En la figura $26 \mathrm{~F}$ no se observan granos de polen en el interior del reducido saco polínico. Los tipos celulares de la superficie externa de la antera transgénica no muestran grandes diferencias con los de una antera silvestre, pero aparecen tricomas que no se observan en esta última (Figura $26 \mathrm{E}$ ). 

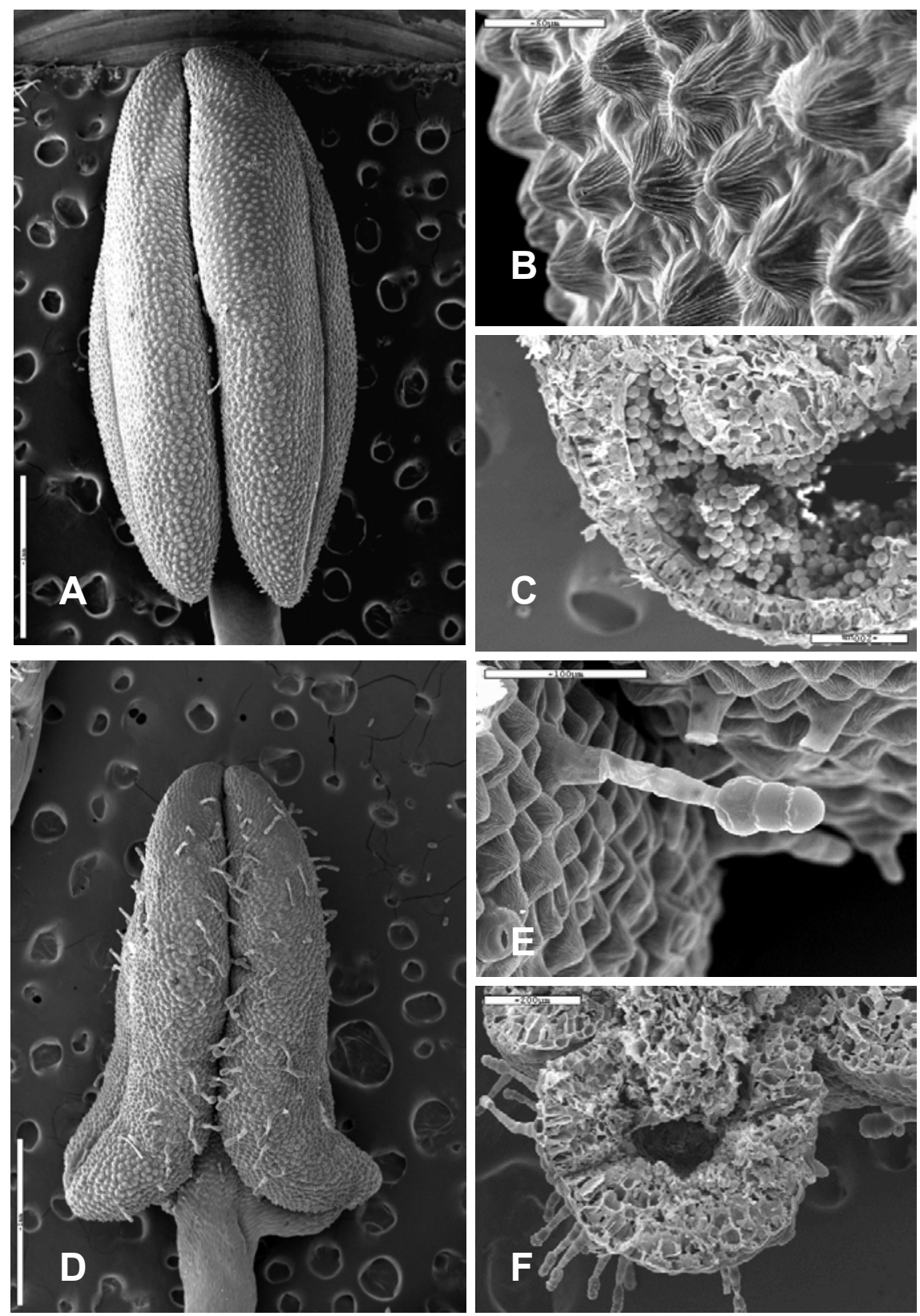

Figura 26. Análisis SEM de las características morfológicas de anteras END1::barnasa de Nicotiana tabacum. Comparación con anteras control. A, Antera de una planta silvestre. Muestra su forma característica de pala. B, Tipos celulares de la epidermis de una antera control. C, Granos de polen en el interior de un saco polínico de una antera control. D, Antera de la planta TAB 1. Forma similar a una punta de flecha. E, Tipos celulares de la epidermis de una antera de una planta TAB 1. Aparecen tricomas intercalados entre las células epidérmicas a diferencia de lo que se observa en $B$. F, Saco polínico vacío de una antera de la planta TAB 1. 
Con objeto de comparar los tejidos presentes en ambos tipos de anteras, se prepararon secciones transversales de anteras silvestres y anteras transgénicas incluidas en parafina y se observaron por microscopía óptica (Figura 27). La antera silvestre muestra los tejidos especializados característicos: epidermis, endotecio, capa intermedia, conectivo, haz vascular, estomio y microsporas uninucleadas. Por la presencia y disposición de los mismos se puede decir, según los estadios de desarrollo de la antera de tabaco descritos por Koltunow et al. (1990), que la antera se encuentra en un estadio de desarrollo 6 aproximadamente en el cual quedan restos de tapetum y las microsporas uninucleadas están a punto de entrar en mitosis para dar lugar a los granos de polen (Figura 27 A). La antera de una flor de la planta TAB 1 en un estadio de desarrollo similar muestra un engrosamiento en las paredes de los sacos polínicos y se observa un aumento en el número de células del endotecio. El tejido conectivo se ha colapsado haciendo que converjan en el haz vascular los cuatro sacos polínicos malformados. Estos muestran en su interior un tejido amorfo en lugar de los tejidos reproductivos especializados correspondientes (Figura $27 \mathrm{~B}$ ).
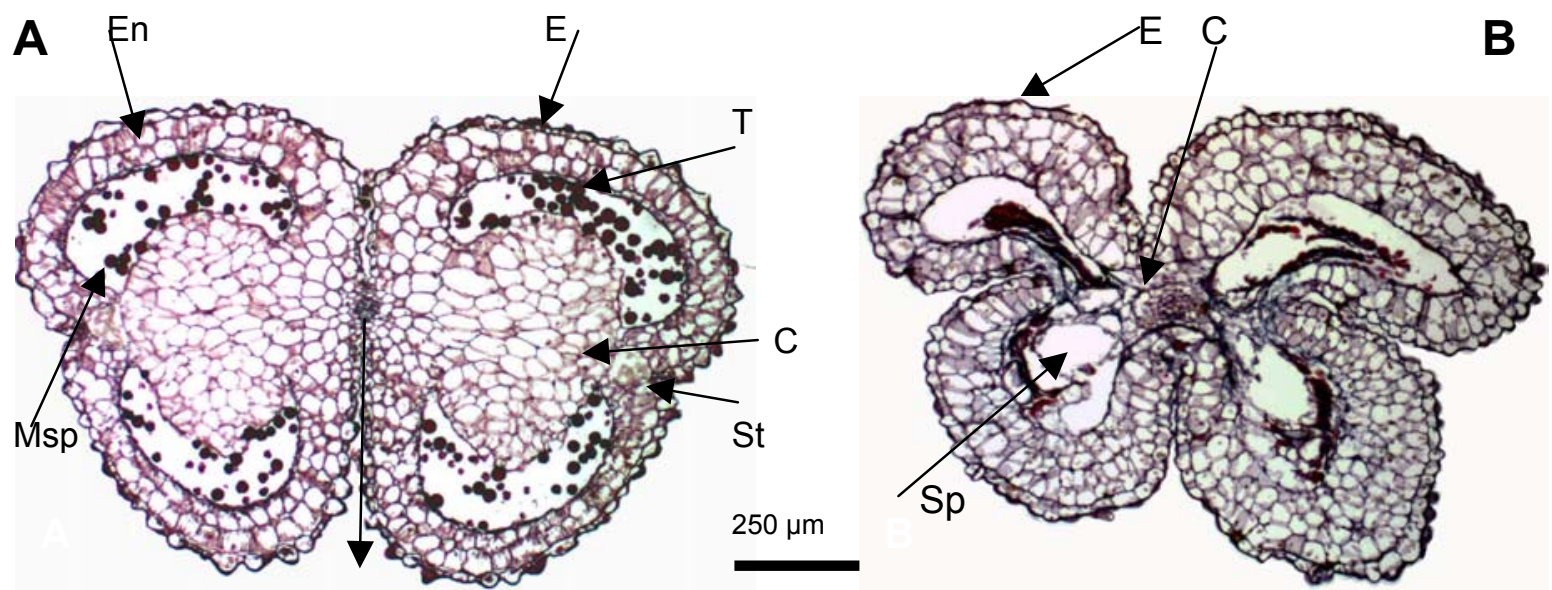

HV

Figura 27. Anormalidades en los tejidos de anteras de la planta TAB1. A, Sección transversal de una antera de tabaco no transformada. La antera se encuentra en la segunda fase del desarrollo de la antera de tabaco, en un estadio de desarrollo 6, aproximadamente, según los definidos por Koltunow et al. (1990). Están presentes los tejidos: epidermis (E), endotecio (En), conectivo (C), estomio (St) y haz vascular (HV), se observan restos de tapetum (T) y microsporas uninucleadas (Msp) a punto de entrar en mitosis para dar lugar a granos de polen. B, Sección transversal de una antera de la planta TAB 1. Para un estadio de desarrollo similar al representado en A, la antera presenta el tejido conectivo colapsado hacia el haz vascular y en el interior de los sacos polínicos $(\mathrm{Sp})$ se observa un tejido amorfo. Las capas celulares que conforman el endotecio y la capa intermedia están también alteradas y desorganizadas. 


\section{OBTENCIÓN DE PLANTAS TRANSGÉNICAS ANDROESTÉRILES Y DESARROLLO PARTENOCÁRPICO DEL FRUTO EN LYCOPERSICON ESCULENTUM}

Con la transformación de plantas de tomate con la construcción pBI-END1::barnasa-barstar se perseguían dos objetivos. Por un lado, se pretendía comprobar si el promotor de END1 podría ser una herramienta eficaz en la generación de plantas androestériles en una especie de interés agronómico como el tomate.

Por otra parte, si efectivamente la expresión del transgén END1::barnasa en plantas de tomate fuese capaz de producir malformaciones en las anteras similares a las producidas en plantas transgénicas de Arabidopsis y tabaco, estas plantas de tomate podrían servir como sistema para testar si la androesterilidad tiene relación con el desarrollo partenocárpico del fruto. Este objetivo tiene su fundamento en observaciones previas que sugieren que la partenocarpia en el mutante de tomate pat podría ser un efecto inducido por las malformaciones en los estambres y los óvulos, que interfieren en el proceso reproductor (Mazzucato et al., 1999).

\subsection{Transformación de Lycopersicon esculentum (cv. Micro-Tom) con la construcción pBI-END1::barnasa-barstar}

La transformación de plantas de tomate generó 72 brotes transgénicos primarios $\left(T_{1}\right)$, de los que se escogieron 25 brotes. Las plantas seleccionadas se analizaron mediante citometría de flujo, con el fin de evaluar el nivel de ploidía. De los 25 transformantes, 24 eran diploides y solo la planta 7A resultó ser tetraploide (Tabla 13). El análisis mediante PCR a partir de DNA genómico aislado de muestras de tejido de los transformantes diploides, permitió detectar la presencia del transgén en todos ellos (Figura 28). Se escogieron 14 plantas para ser transferidas al invernadero y poder analizar sus características fenotípicas (Tabla 13).

Las plantas transgénicas mostraron un desarrollo similar al de plantas no transformadas crecidas bajo las mismas condiciones. Las flores de las plantas control, al igual que las de las plantas END1::barnasa, desarrollaron los órganos característicos de la flor de tomate: cinco sépalos alternando con cinco pétalos y dos carpelos fusionados formando un pistilo. 
Tabla 13. Características genotípicas y fenotípicas de plantas de tomate END1::barnasa de la generación $\mathrm{T}_{1}$.

\begin{tabular}{|c|c|c|c|c|}
\hline $\begin{array}{c}\text { Callos } \\
\text { independientes }\end{array}$ & Brotes $^{a}$ & $\begin{array}{l}\text { Nivel de } \\
\text { Ploidia }\end{array}$ & ${ }_{\text {Invernadero }}^{\text {Plantas }}$ & Fenotipo $^{c}$ \\
\hline \multirow{4}{*}{1} & $1 \mathrm{a}$ & $2 x$ & & \\
\hline & $1 \mathrm{~d}$ & $2 x$ & $x$ & severo \\
\hline & $1 \mathrm{e}$ & $2 x$ & $x$ & severo \\
\hline & $1 \mathrm{f}$ & $2 x$ & $x$ & severo \\
\hline \multirow{2}{*}{2} & $2 d$ & $2 x$ & $X$ & leve \\
\hline & $2 \mathrm{e}$ & $2 x$ & $x$ & leve \\
\hline \multirow{3}{*}{4} & $4 \mathrm{a}$ & $2 x$ & & \\
\hline & $4 p$ & $2 x$ & $x$ & leve \\
\hline & $4 \mathrm{~s}$ & $2 x$ & $x$ & leve \\
\hline 5 & $5 \mathrm{~b}$ & $2 x$ & $x$ & medio \\
\hline 7 & $7 a$ & $4 x$ & - & - \\
\hline \multirow{4}{*}{9} & $9 \mathrm{~b}$ & $2 x$ & $X$ & medio \\
\hline & $9 \mathrm{~h}$ & $2 x$ & & \\
\hline & $9 \mathrm{~g}$ & $2 x$ & & \\
\hline & 91 & $2 x$ & $x$ & medio \\
\hline \multirow{2}{*}{11} & $11 \mathrm{c}$ & $2 x$ & & \\
\hline & $11 \mathrm{~d}$ & $2 x$ & $x$ & severo \\
\hline \multirow{3}{*}{12} & $12 \mathrm{~b}$ & $2 x$ & $X$ & medio \\
\hline & $12 \mathrm{c}$ & $2 x$ & & \\
\hline & $12 \mathrm{~d}$ & $2 x$ & & \\
\hline \multirow{2}{*}{14} & $14 \mathrm{c}$ & $2 x$ & $X$ & medio \\
\hline & $14 \mathrm{~d}$ & $2 x$ & & \\
\hline \multirow{3}{*}{15} & $15 d$ & $2 x$ & & \\
\hline & $15 \mathrm{e}$ & $2 x$ & $x$ & leve \\
\hline & $15 \mathrm{f}$ & $2 x$ & & \\
\hline
\end{tabular}

a Brotes transgénicos primarios individualizados de cada callo.

b Plantas aclimatadas en el invernadero a partir de ápices individualizados de cada brote.

${ }^{\mathbf{C}}$ Fenotipo de las anteras en cada planta transgénica analizada

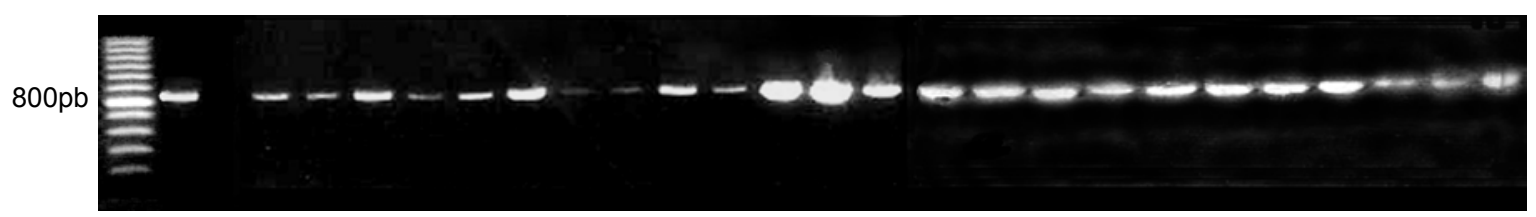

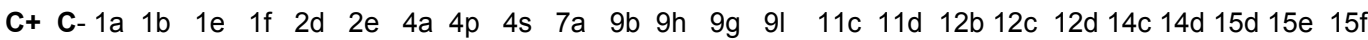

Figura 28. Amplificación del fragmento barnasa-barstar del genoma de plantas END1::barnasa de tomate (cv. Micro-Tom). En el pie de la figura aparecen los nombres de las distintas plantas transformantes a las que se les realizó la comprobación por PCR de la presencia del transgén en estudio. Como control positivo $(\mathrm{C}+)$ se utilizó la construcción pBI-END1::barnasa-barstar y como control negativo (C-) se usó el plásmido pBI101. 
Sin embargo, mientras que los cinco estambres de las plantas control formaban el cono estaminal característico alrededor del estilo (Figura 29 A), el fenotipo de los estambres de las plantas transgénicas variaba de una planta a otra. Se observaron transformantes con estambres muy parecidos a los estambres silvestres (Tabla 13; Figura 29 B y C, fenotipo leve); otros mostraban una ligera reducción de su tamaño y una pequeña separación entre ellos (Tabla 13; Figura 29 D y E, fenotipo medio); y por último otras plantas mostraron estambres atrofiados que dejaban el estilo al descubierto (Tabla 13; Figura 29 F, fenotipo severo).

Las anteras transgénicas de fenotipo leve contenían granos de polen en su interior y esto se podía observar a simple vista realizando una incisión en las mismas.
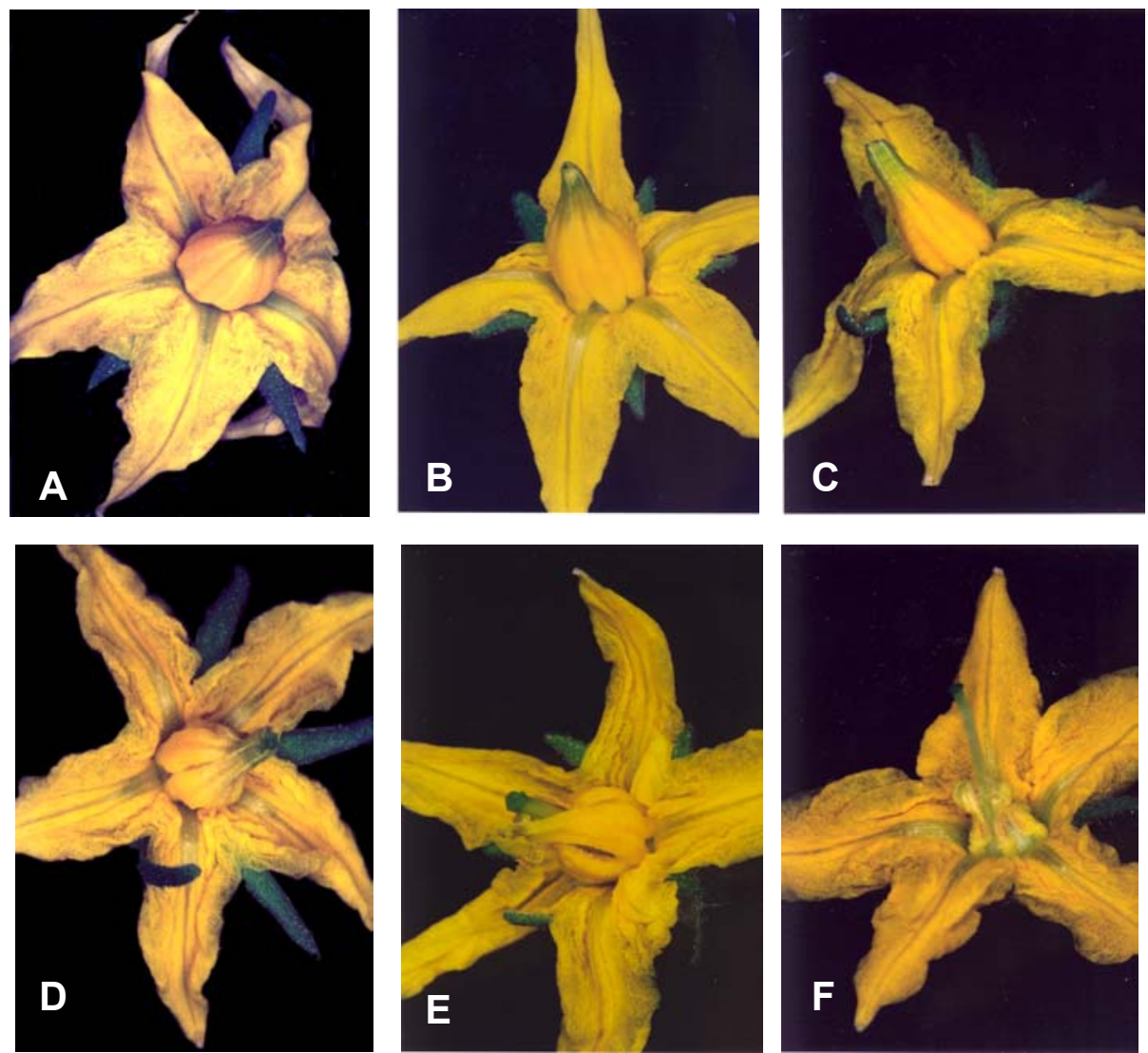

Figura 29. Fenotipo de flores de tomate de plantas transgénicas END1::barnasa. A, Flor de una planta de tomate no transformada. B, Flor de la planta END1::barnasa 4s. Fenotipo leve de malformación de las anteras. C, Flor de la planta END1::barnasa 15e. Fenotipo leve de malformación de las anteras. D, Flor de la planta END1::barnasa 9l. Fenotipo medio de malformación de las anteras. E, Flor de la planta END1::barnasa 12b. Fenotipo medio de malformación de las anteras. $\mathbf{F}$, Flor de la planta END1::barnasa 1e. Fenotipo severo de malformación de las anteras. 


\subsection{Estudio comparativo del desarrollo de una antera silvestre de tomate (cv. Micro-} Tom) y una antera END1::barnasa de fenotipo severo

Con el objetivo de comparar las diferencias a nivel histológico entre las anteras transgénicas de fenotipo severo y las anteras silvestres de tomate durante su desarrollo, se realizó un estudio comparativo del desarrollo de ambas anteras. Para ello, incluimos en resina y parafina anteras de diferentes estadios de desarrollo y realizamos secciones transversales de las mismas, para observar cuando comienzan a afectarse los tejidos de la antera por la acción del gen citotóxico barnasa.

En la figura 30 se muestran cinco estadios representativos del desarrollo de la antera silvestre de tomate (cv. Micro-Tom) en comparación con estadios equivalentes del desarrollo de anteras transgénicas. La división en los estadios del desarrollo de la antera silvestre de tomate se ha realizado teniendo en cuenta los definidos por Koltunow et al. (1990) para el desarrollo de la antera de tabaco y los descritos por Brukhin et al. (2003) para el desarrollo de la antera de la flor la variedad cherry de tomate dulce.

\section{Estadio 1.}

Silvestre: El primer estadio analizado muestra un primordio de antera donde las células arquesporiales ya se han diferenciado en células parietales primarias y esporogéneas. Se empieza a establecer el tejido conectivo, la epidermis y el haz vascular.

END1::barnasa: Para este mismo estadio, la antera transgénica ya muestra una apariencia anormal. Su forma es diferente a la que adquiere una antera silvestre en el estadio equivalente. Esta morfología recuerda a la que tendría una antera silvestre en un estadio de desarrollo inferior. Las principales diferencias se concentran en las cuatro esquinas del primordio, donde no se observan marcados los futuros sacos polínicos.

\section{Estadio 2.}

Silvestre: Se han formado los tejidos epidermis, conectivo y haz vascular. Se están formando las paredes de los sacos polínicos que incluye el endotecio, el tapetum y la capa intermedia y se ha diferenciado el tejido esporógeno.

END1::barnasa: Las células que conforman la epidermis muestran diferencias con las correspondientes a una antera silvestre: son más redondas y pequeñas. Hay menor número de células dentro del tejido conectivo y también son menos y con una disposición diferente las que darían lugar a los tejidos que rodean el saco polínico. La antera silvestre en este estadio de desarrollo está alcanzando su forma externa característica. Comienzan a observarse sus cuatro lóbulos donde se establecerán los sacos polínicos y se diferenciarán 


\section{Silvestre (A)}
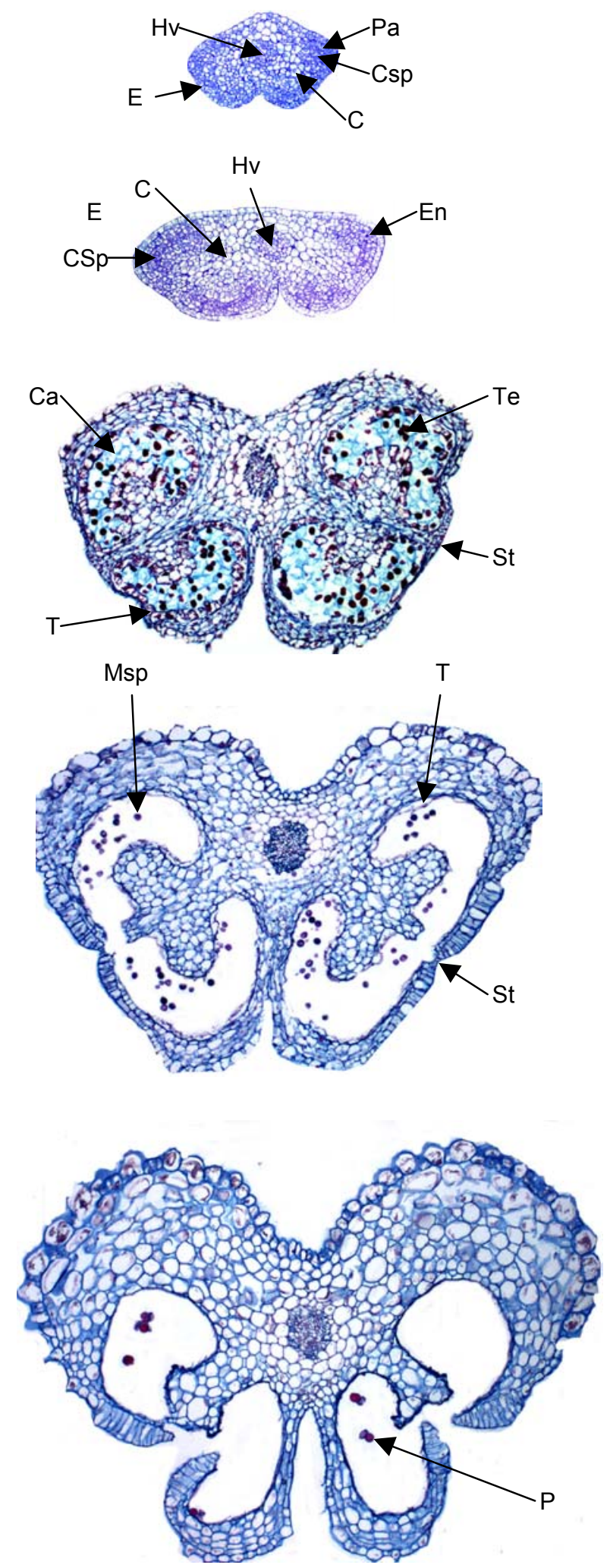

Estadio END1::barnasa (B)

1

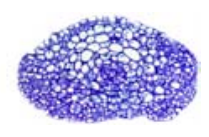

2

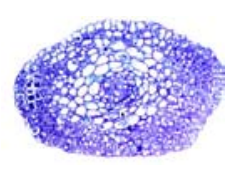

3

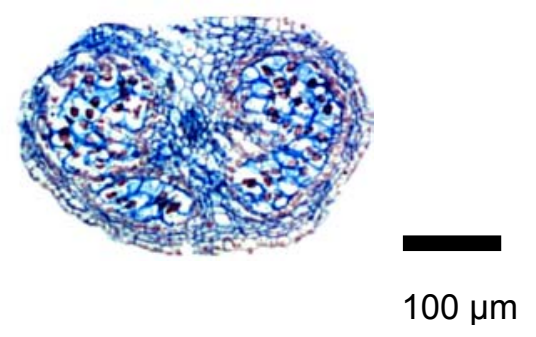

4

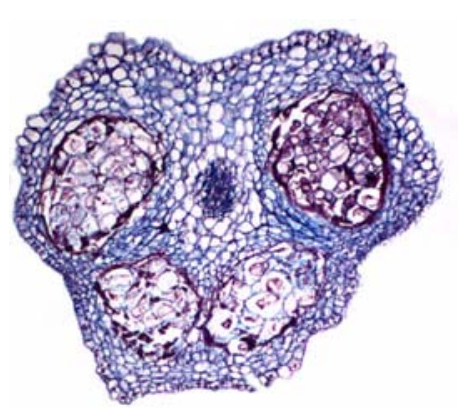

5

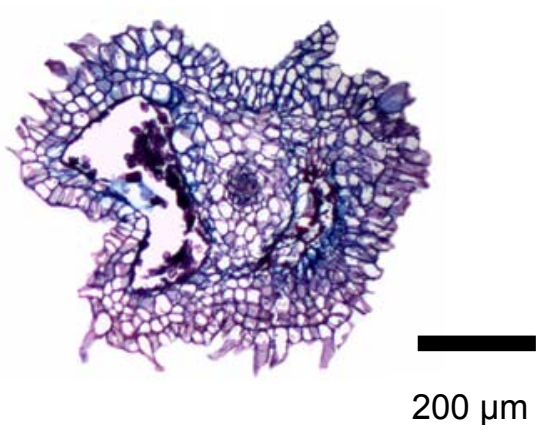

Figura 30. Desarrollo de la antera de tomate en plantas no transformadas y en plantas END1::barnasa con fenotipo severo de malformación en las anteras. A, Desarrollo de antera en plantas silvestres de tomate (cv. Micro-Tom). B, Desarrollo de antera en plantas de tomate (MicroTom) END1::barnasa que mostraron un fenotipo severo de malformación en las anteras. 
E, epidermis; En, endotecio; C, conectivo; Pa, células parietales; Csp, células esporógenas; Hv, haz vascular; Te, tétradas; Ca, callosa; T, tapetum; Msp, microsporas; St, estomio, P, granos de polen.

en su interior las células que darán lugar a los granos de polen. Esto no se observa en la antera transgénica en el estadio equivalente.

\section{Estadio 3.}

Silvestre: Se observa el tapetum rodeando las tétradas de microsporas que a su vez están rodeadas de callosa. Los demás tejidos de la antera están completamente diferenciados. END1::barnasa: La morfología externa de la antera muestra signos de malformación: los sacos polínicos están dispuestos de manera diferente a los de una antera silvestre, más cerca unos de otros y en su interior el tapetum rodea a posibles tetrasporas recubiertas de callosa. Esto posiblemente se debía a que el tejido conectivo está colapsado y hace que los miscrosporangios converjan en un punto central.

\section{Estadio 4.}

Silvestre: La antera muestra señales de haber entrado en dehiscencia: el tapetum y las células adyacentes al estomio han degenerado, ha desaparecido el tejido conectivo de la región que dividía los dos sacos polínicos de una teca, convirtiendo a la antera en bilocular. Se observan microsporas en el interior de los sacos polínicos.

END1::barnasa: Se siguen manteniendo las diferencias en la morfología externa: el tejido conectivo está colapsado y no hay señales de haber entrado en dehiscencia. En lugar de granos de polen maduro se observa una estructura amorfa en el interior de los sacos polínicos y ésta parece rodeada de tapetum.

\section{Estadio 5.}

Silvestre: La antera se ha abierto por la región del estomio y los granos de polen maduro están siendo liberados por la abertura que se ha producido.

END1::barnasa: La antera se ha hecho bilocular pero los sacos polínicos están deformados y en su interior aparecen estructuras amorfas en lugar de granos de polen maduro. El tamaño de la antera es mucho menor y su morfología externa sigue siendo diferente a la de una antera silvestre en un estadio equivalente. Aunque hay algunas señales de haber entrado en dehiscencia, como la bilocularidad de la antera, ésta no ha llegado a término. No se ha producido la degradación completa del tejido conectivo por la región del estomio, que provoca la apertura de la antera silvestre. 


\subsection{DESARROLLO PARTENOCÁRPICO DE LOS FRUTOS EN LAS PLANTAS DE TOMATE END1::BARNASA}

Todas las plantas de tomate END1::barnasa produjeron frutos. Los frutos producidos carecian de semillas y eran por tanto partenocárpicos. Esto fue así en todos los casos analizados independientemente de la severidad del fenotipo de las anteras y de la presencia o no de granos de polen observada para algunos transformantes de fenotipo leve. El desarrollo de los frutos en las plantas transgénicas comenzaba antes de que se iniciara en las plantas silvestres. Así, los ovarios transgénicos de flores de día 0 (antesis) mostraban un tamaño notablemente mayor que los de las flores silvestres en el mismo estadio de desarrollo (Figura 31). Aparentemente en las flores de plantas END1::barnasa la antesis no se hallaba retrasada respecto a las flores de las plantas silvestres y en ese estadio los sépalos y los pétalos de ambos tipos de flores tenían la misma forma y tamaño.

Los frutos transgénicos tenían un peso y un tamaño menor que los frutos silvestres; además, mostraban un color rojo más intenso (Figura 32). Cuando las flores de las transgénicas END1::barnasa fueron emasculadas y polinizadas con polen de anteras de plantas silvestres, se obtuvieron frutos que alcanzaban un tamaño normal y que tenían semillas similares, en número y morfología, a las producidas por los frutos de las plantas silvestres. En la tabla 14 se muestran datos referentes a las diferencias en tamaño y peso entre frutos partenocárpicos y frutos obtenidos por polinización cruzada en 4 líneas transgénicas independientes.

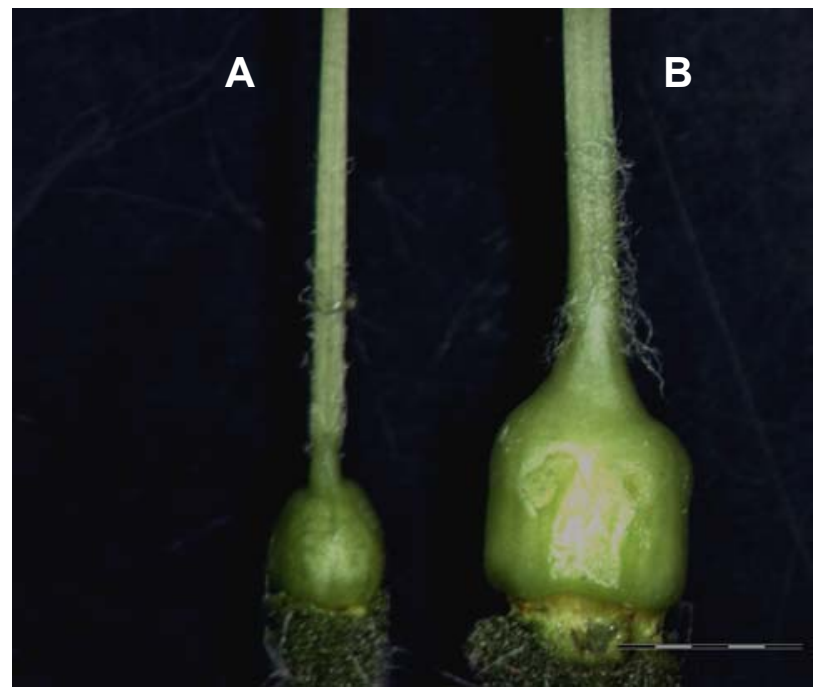

Figura 31. Comparación entre ovarios de día 0 (antesis) de plantas transgénicas de tomate END1::barnasa y plantas silvestres. A, Ovario de una flor control en antesis. B, Ovario de una flor END1::barnasa en antesis. 


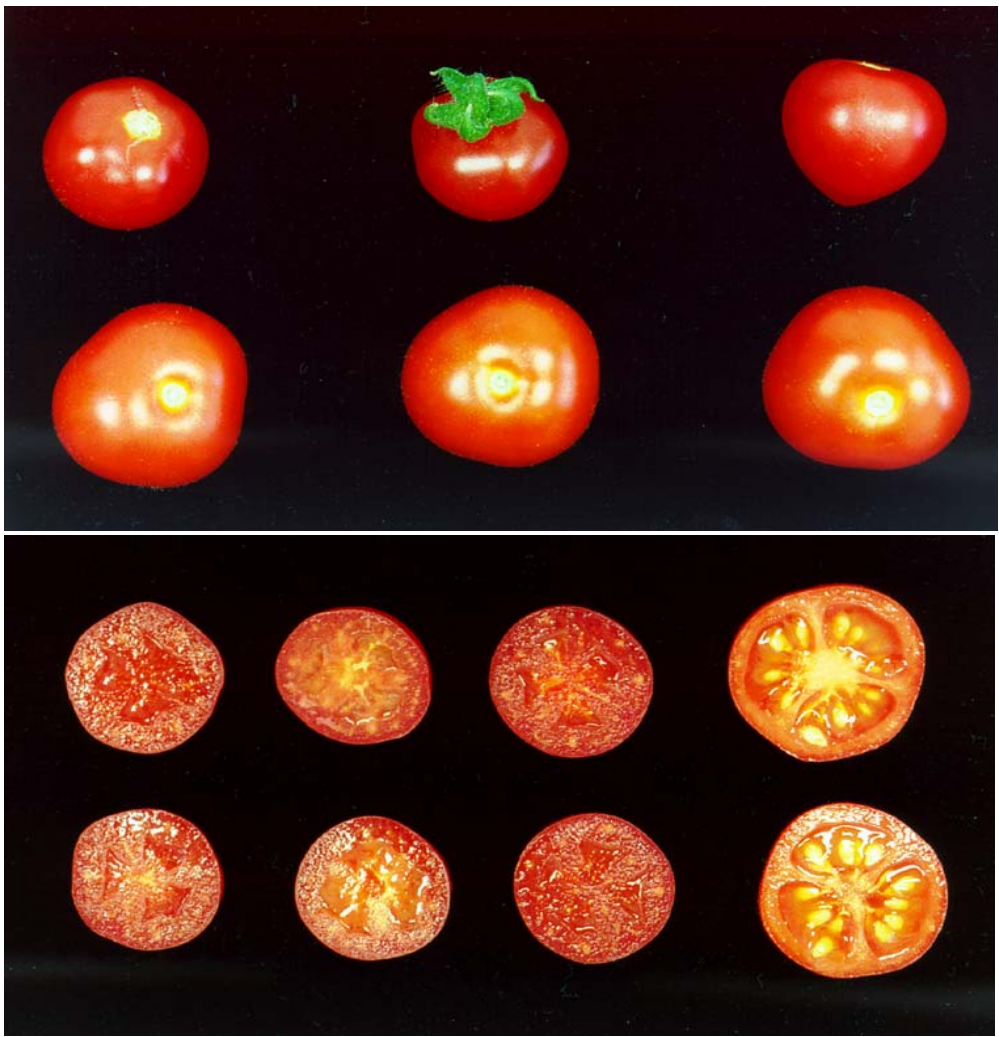

Figura 32. Frutos partenocárpicos desarrollados por plantas END1::barnasa de tomate (cv. Micro-Tom). A, Frutos enteros de plantas END1::barnasa (arriba) y plantas silvestres (abajo). B, Frutos seccionados transversalmente de plantas no transformadas (derecha) y plantas END1::barnasa (izquierda).

Tabla 14. Diferencias entre los frutos partenocárpicos generados por plantas END1::barnasa y frutos obtenidos por polinización de flores de estas mismas plantas con flores de tipo silvestre.

\begin{tabular}{c|c|c|c|c}
\hline \multirow{2}{*}{ Genotipo } & \multicolumn{2}{|c|}{ Frutos Partenocárpicos } & \multicolumn{2}{c}{ Frutos obtenidos por polinización } \\
\cline { 2 - 5 } & Peso $\mathbf{( g )})^{\mathbf{a}}$ & ${\text { Diámetro } \mathbf{( c m})^{\mathbf{a}}}^{\text {Peso }(\mathbf{g})^{\mathbf{a}}}$ & Diámetro (cm) $^{\mathbf{a}}$ \\
\hline silvestre & - & - & 10 & 2.9 \\
$1 \mathrm{e}$ & 4.25 & 2.05 & 9.35 & 2.55 \\
$4 \mathrm{~s}$ & 3.60 & 2.00 & 9.76 & 2.76 \\
$11 \mathrm{~d}$ & 6.61 & 2.33 & 9.48 & 2.88 \\
$12 \mathrm{~b}$ & 7.04 & 2.70 & 9.25 & 2.60 \\
\hline
\end{tabular}

\footnotetext{
${ }^{\mathrm{a}}$ Los datos de peso y tamaño de los frutos mostrados corresponden con la media de estos valores
} en 6 frutos de cada planta. 


\subsection{Análisis de la viabilidad y germinación del polen en anteras END1::barnasa de fenotipo medio y leve}

Como se ha comentado, la presencia de frutos partenocárpicos se observó en todas las plantas de tomate, independientemente del grado de malformación mostrado por las anteras y de la presencia de granos de polen. No parecía haber, por lo tanto, una correlación entre el desarrollo del ovario y el grado de malformación en las anteras. Para comprobar si existía entonces en las transgénicas una relación entre el desarrollo de frutos partenocárpicos y la capacidad de las anteras de producir polen viable, analizamos la funcionalidad de los granos de polen en las flores de fenotipo medio y leve. Para ello, sometimos a los granos de polen de estas plantas a un ensayo de germinación in vitro. Además sometimos los mismos a una tinción con acetato de carmín para observar su viabilidad.

Los datos mostrados en la tabla 15 muestran que el número de granos de polen germinados de las anteras transgénicas es netamente inferior al número de granos de polen germinados de las anteras de las plantas silvestres. Esto se puede apreciar en la figura que muestra la tinción de los granos de polen con acetato de carmín (figura 33), en la que se observa además que la viabilidad del polen transgénico es muy baja.

A pesar de constatar la presencia de un cierto número, muy pequeño, de granos de polen viables, y con aptitud germinativa, en anteras de plantas END1::barnasa, nunca se observó en ninguno de los frutos transgénicos la presencia de una sola semilla. La disminución de la cantidad, viabilidad y capacidad germinativa de los granos de polen de anteras transgénicas, así como las alteraciones morfológicas de los estambres (estilo casi fuera del cono estaminal), son, probablemente, los factores responsables de la ausencia de semillas en los frutos de las plantas END1::barnasa. 
Tabla 15. Resultado del ensayo de germinación in vitro de los granos de polen de anteras de plantas de tomate END1::barnasa.

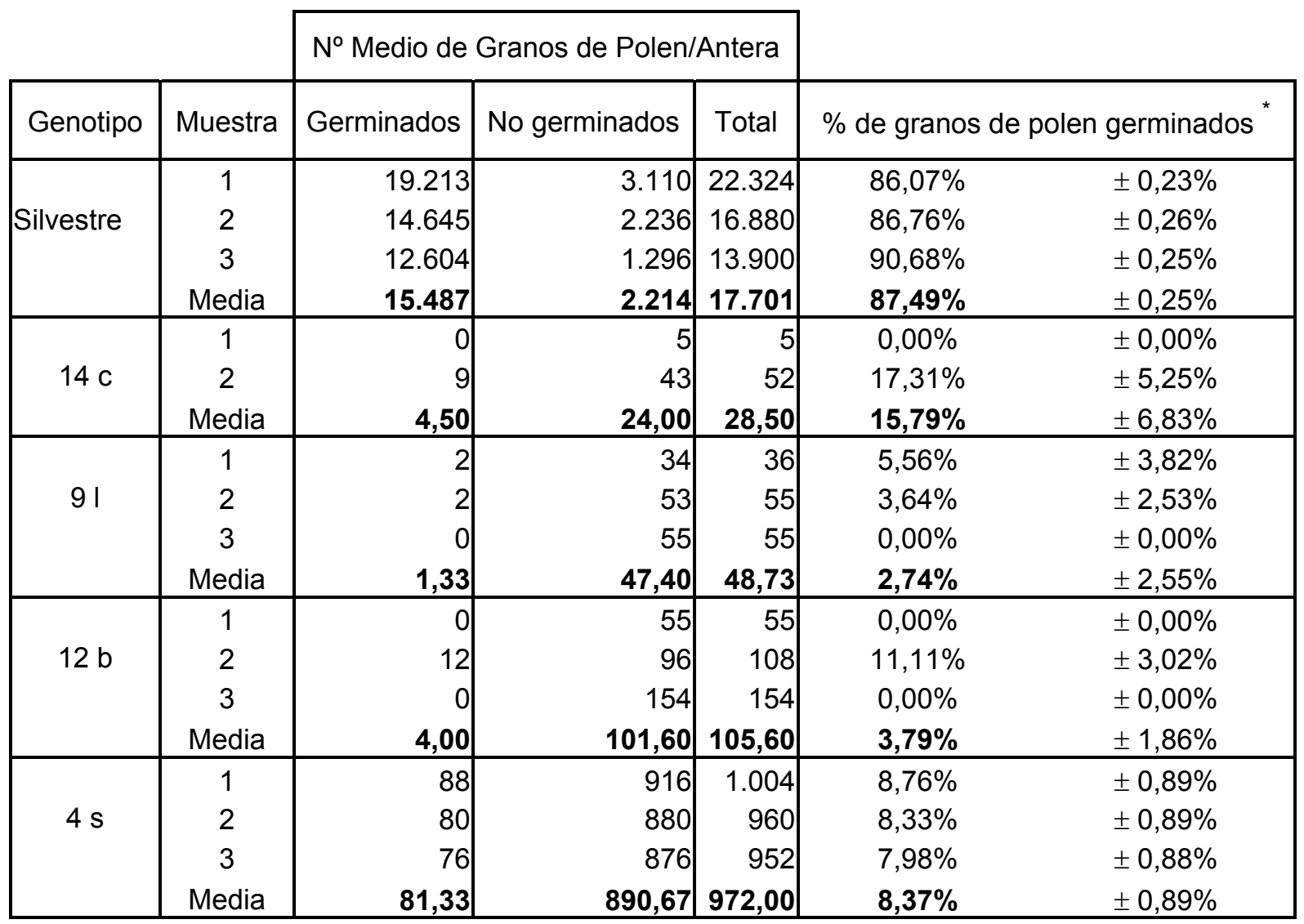

* Se indican los porcentajes $(\mathrm{P})$ de germinación y las desviaciones asociadas a cada uno de ellos. $P \pm \sqrt{\frac{P^{*}(1-P)}{N}}$

$N$, Número total de granos. 


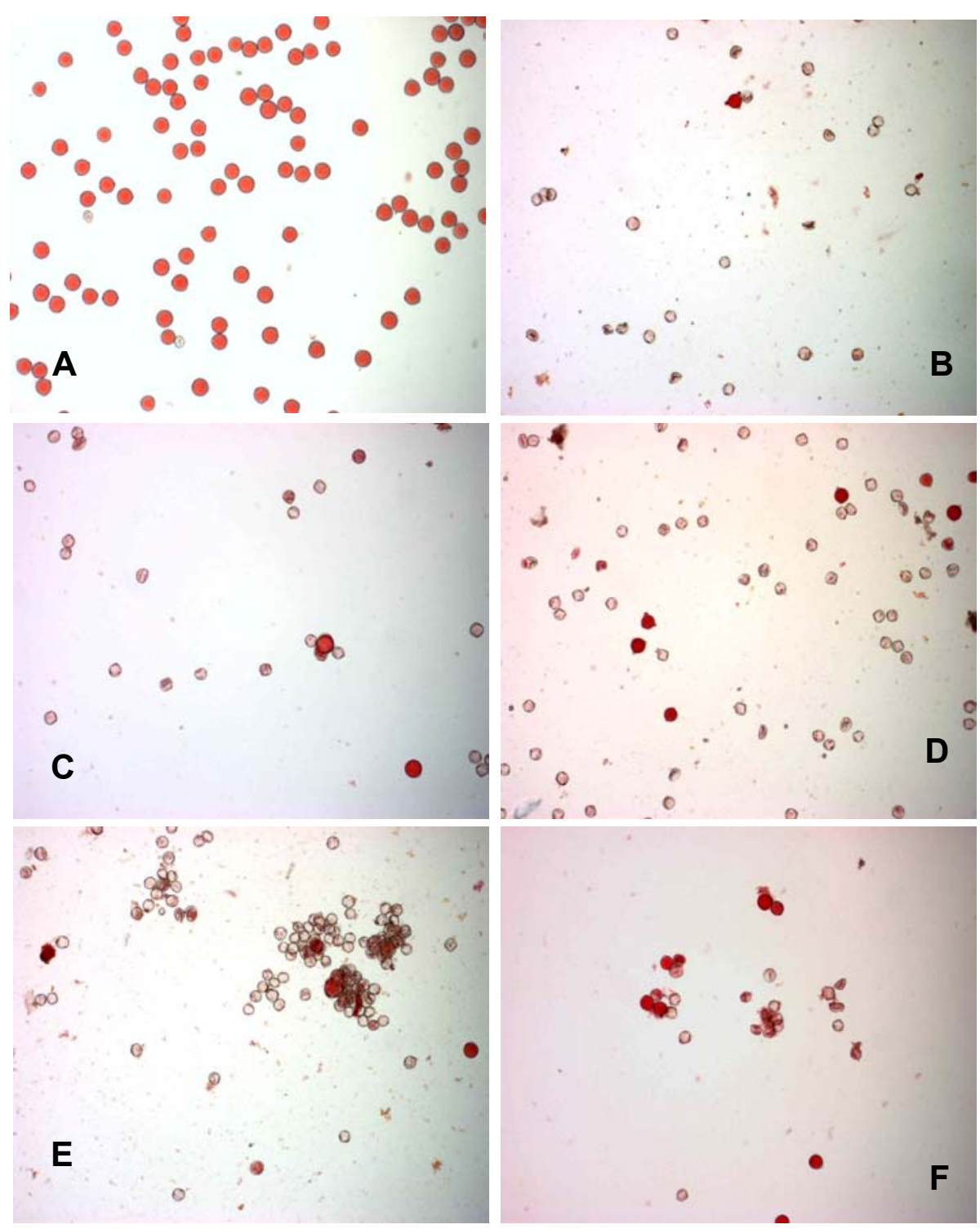

Figura 33. Tinción vital con acetato de carmín del polen de plantas de tomate (cv. Micro-Tom) END1::barnasa. A, Granos de polen de una antera de una planta no transformada. B, Granos de polen de la planta END1::barnasa 9b. C, Granos de polen de la planta END1::barnasa 2e. D, Granos de polen de la planta END1::barnasa 12b. E, Granos de polen de la planta END1::barnasa 4s. F, Granos de polen de la planta END1::barnasa $15 \mathrm{e}$. 


\section{ANÁLISIS FUNCIONAL DEL PROMOTOR DEL GEN END1 DE GUISANTE}

\subsection{Breve descripción de la secuencia promotora de END1}

En nuestro laboratorio se había llevado a cabo previamente el aislamiento, y el análisis preliminar de la funcionalidad del promotor del gen END1 de guisante. Mediante ensayos de transformación de Arabidopsis, tabaco y tomate con las construcciones pBI101-F3 y pBI101-F1.5, donde los fragmentos correspondientes a la región 5' de la secuencia genómica de END1 comprendida entre los -2736 y -6 pb y la comprendida entre los -1531 y $-6 \mathrm{pb}$, respectivamente, se fusionaron al gen uidA (que codifica la enzima $\beta$-glucuronidasa, GUS), se comprobó que este promotor era capaz de dirigir la expresión específica de dicho gen a las anteras de otras plantas diferentes del guisante (Gómez, 2000; Gómez et al., 2004).

El análisis informático de la secuencia promotora de END1 reveló que en posiciones-263 y -56 se encuentran dos posibles cajas TATA; en posiciones -347 y -66 dos putativas cajas CCAAT; y en posición -401 una caja CAAT. Además se identificaron otras secuencias que corresponden a cajas típicas de promotores de plantas utilizando la base de datos del Instituto Nacional de Recursos Agrobiológicos de Japón (Gómez, 2000; Gómez et al., 2004). Entre éstas cabe destacar motivos tales como el elemento ${ }^{-290}$ GTCAAAAA $^{-284}$, presente en los genes específicos de polen ZM13 de maíz y LAT52 de tomate (Zou et al., 1994). También se localizó el elemento ${ }^{-127} A C G T C A^{-122}$ (similar al "elemento Q"), presente en otros promotores específicos de antera, y el elemento $C(A)_{6 / 8}$ repetido tres veces en posiciones $-507,-288,-247$. En los promotores de los genes específicos de antera OlnB4 y OlnB19 de Brassica también se encuentran repeticiones de este motivo (Hong et al., 1997).

Se detectó también la presencia de dos secuencias: ${ }^{-222}$ CCAACTCATGG $^{-212}$ (Motivo CArG 1) $y^{-103}$ CCCAAAATGG $^{-112}$ (Motivo CArG 2) que se asemejan a la secuencia consenso 5 '$\mathrm{CC}(\mathrm{A} / \mathrm{T})_{6} \mathrm{GG}-3$ ' de las cajas CArG. Las cajas $\mathrm{CArG}$ son elementos reguladores a los que se unen los factores de transcripción de tipo MADS-box.

\subsection{Análisis de la expresión de GUS en plantas de Arabidopsis transformadas con construcciones con deleciones de la región promotora de END1}

En este trabajo hemos generado seis construcciones con fragmentos correspondientes a deleciones sucesivas de la región promotora de END1 para determinar la región mínima reguladora capaz de dirigir la expresión espacial y temporal del gen. La primera de estas construcciones contiene la secuencia comprendida entre los -986 pb y -6 pb de la región 5' de END1. Los nucleótidos que componen la misma aparecen representados en la figura 34 
en la que se indican además los posibles elementos reguladores identificados en el análisis informático de la secuencia.

Las distintas construcciones se fusionaron transcripcionalmente al gen delator GUS y con cada una de ellas se transformaron plantas de Arabidopsis thaliana. Para cada una de estas construcciones se analizaron los ápices infloresecentes, con flores de diferentes estadios de desarrollo de varias plantas transgénicas primarias (T1). En cada ápice se realizó el análisis histoquímico de la actividad de la $\beta$ - glucuronidasa (GUS). La intensidad de la señal GUS en las anteras de las distintas transgénicas se clasificó en fuerte, moderada, débil y ausente (Figura 35).

Las deleciones sucesivas que se realizaron contienen los fragmentos -986/-6, -685/-6, $-426 /-6,-366 /-6,-336 /-6$ y -309/-6 y aparecen representadas esquemáticamente en la figura 36. Las flores de las plantas de Arabidopsis que contenían cada una de estas construcciones, excepto las que contenían la construcción -309/-6 (pER15), mostraron actividad GUS en las anteras desde estadios tempranos de desarrollo. En ningún caso se detectó señal GUS en otros órganos distintos de la antera. La distribución del nivel de expresión de GUS en las diferentes líneas transgénicas para cada construcción se muestra en la figura 36. Se observa que las deleciones que contenían los fragmentos desde -986/-6 (pER10) y -685/-6 (pER11) de la región promotora producen un nivel de expresión alto en la mayoría de las plantas analizadas.

En un primer experimento se observó un caída brusca en los niveles de expresión de GUS en la deleción que contenía el fragmento -426/-6 (pER12) lo que no parecía concordar con la mayor proporción de plantas con niveles altos de expresión de GUS para las construcciones con las deleciones -366/-6 (pER13) y -336/-6 (pER14). Al ser estos resultados aparentemente contradictorios se generó una segunda construcción con la deleción de -426/-6 y se volvieron a transformar plantas de Arabidopsis thaliana. Los resultados que se obtuvieron fueron esencialmente iguales a los del experimento anterior. La proporción de plantas con expresión de GUS, que había aumentado para la deleción -366/-6, se mantiene para la deleción -336/-6.

Por último, ninguna de las plantas transformadas con la deleción que contiene el fragmento -309/-6 mostró actividad $\beta$ - glucuronidasa. Podemos concluir que el fragmento -336 pb contiene la región mínima necesaria para dirigir correctamente la expresión del gen END1. 


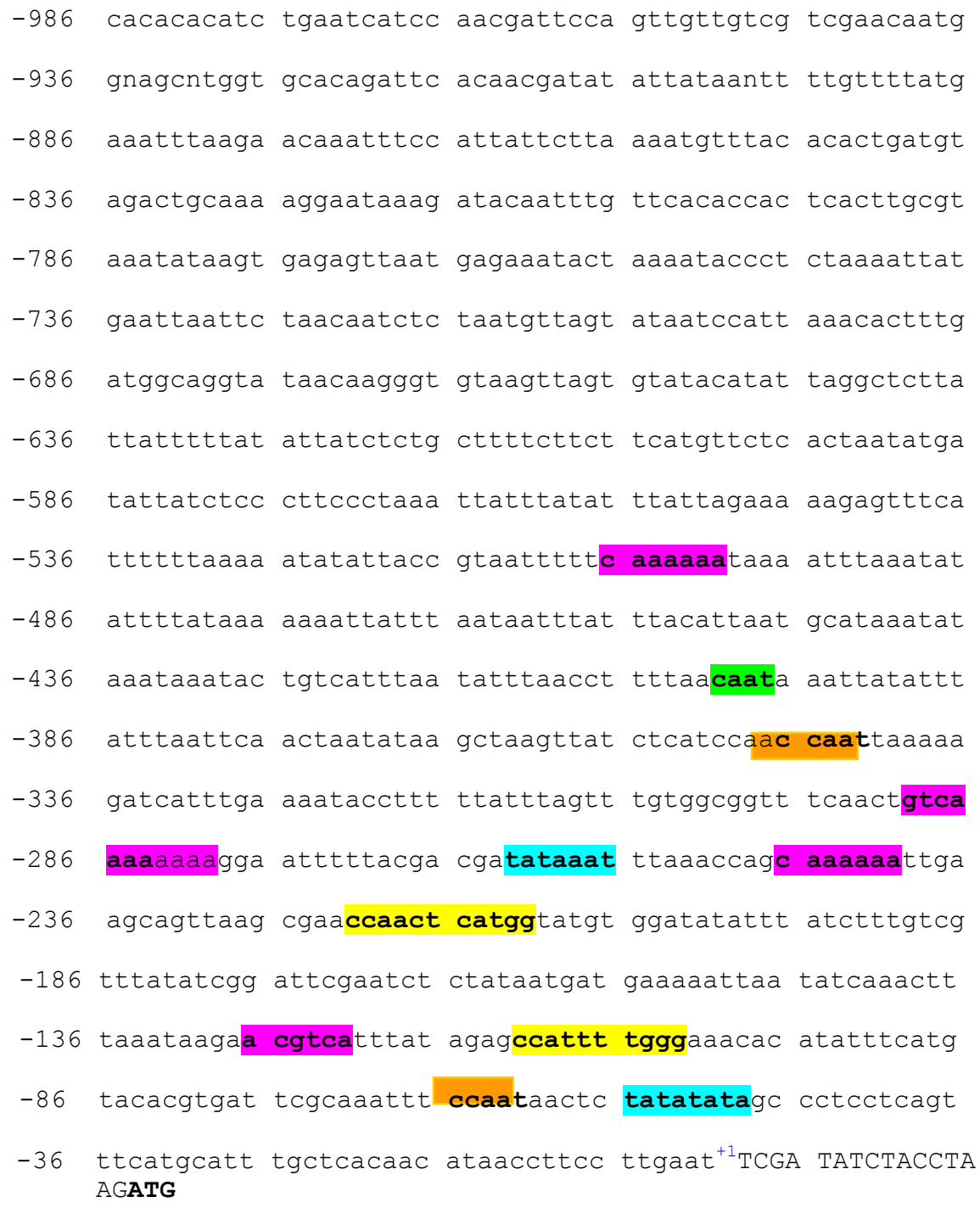

\section{LEYENDA}

$\left.\begin{array}{l}\square \text { ССААТ } \\ \square \text { СААТ }\end{array}\right\}$ Secuencias distales generales de Eucariotas

4 TATA Posibles cajas TATA

C $(A)_{6 / 8}$, "GTCAAAA", "ACGTCA" Elementos presentes en promotores de anteras

(

Posibles cajas CArG

Figura 34. Secuencia nucleotídica comprendida entre los -986 pb de la región promotora y el inicio de la traducción del gen END1. Posibles motivos reguladores más importantes encontrados en la región 5' tras el análisis informático de la misma realizado previamente. Se tomó como nucleótido +1 el primer nucleótido del cDNA aislado (clon 162) de una genoteca de cDNA de flores de guisante (Gómez, 2000; Gómez et al., 2004). 


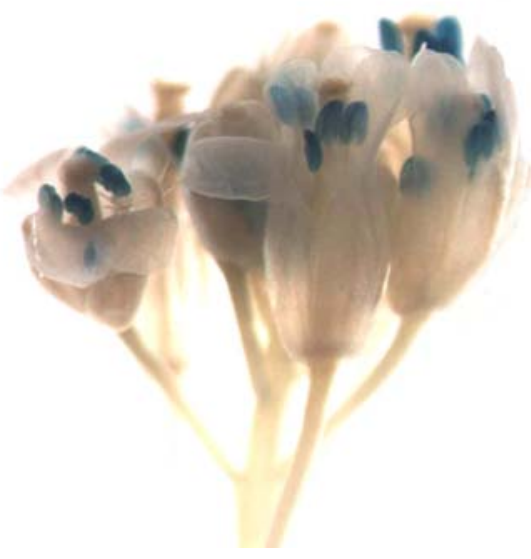

A
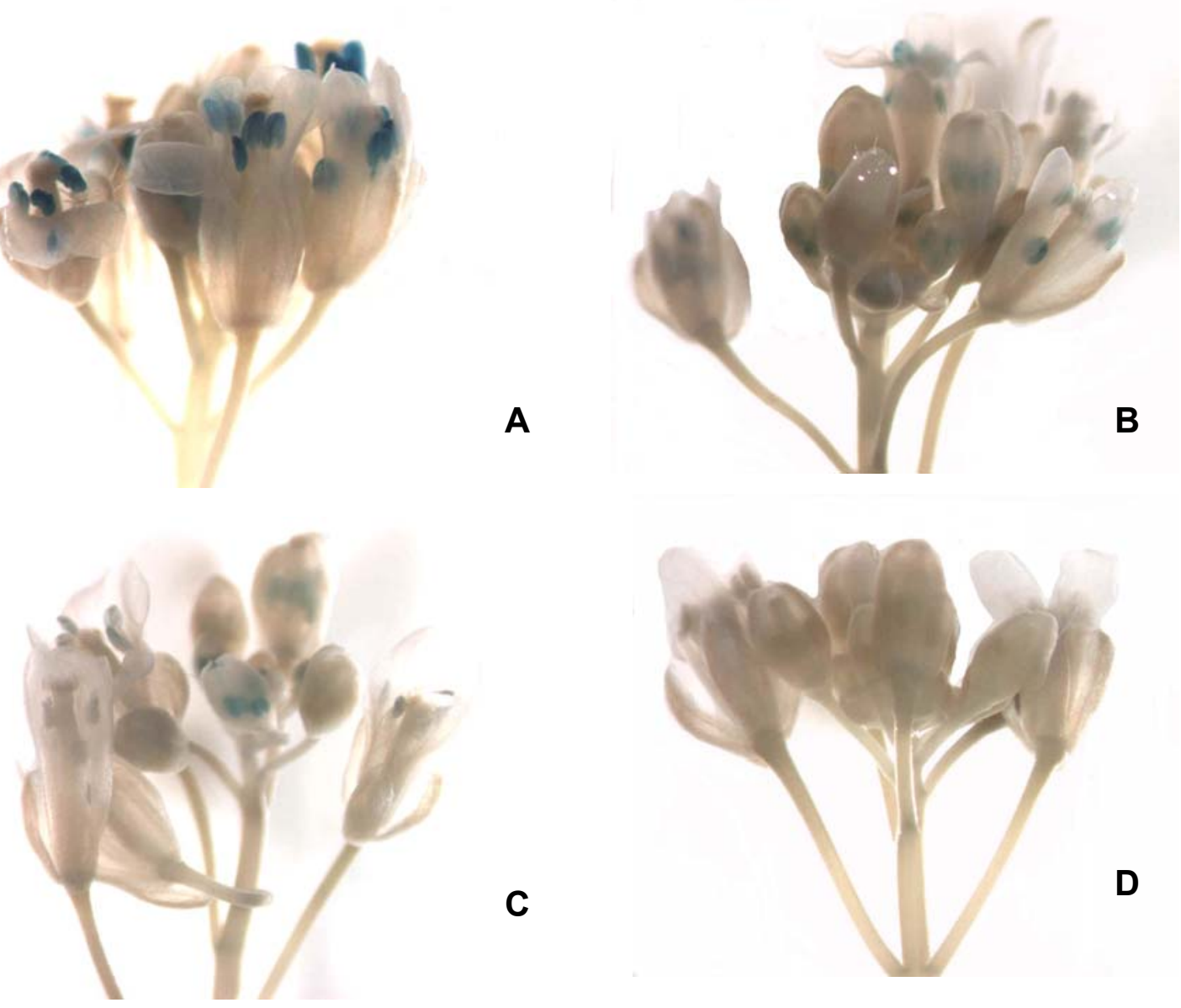

C

Figura 35. Ensayo histoquímico de la actividad de la $\beta$ - glucuronidasa en ápices infloresecentes con flores de diferentes estadios de plantas de Arabidopsis thaliana transformadas con deleciones del promotor de END1. Se muestran los diferentes niveles de expresión de GUS. A, Flores de diferentes estadios de desarrollo que muestran expresión de GUS fuerte especificamente en las anteras. B. Flores que muestran expresión de GUS moderada en anteras. C, Flores que muestran expresión de GUS débil en anteras. D, Flores que no muestran expresión GUS.

\subsection{Análisis de la expresión de GUS en plantas de Arabidopsis transformadas con construcciones que contienen fragmentos de la región promotora de END1 con deleciones internas}

Además de las deleciones sucesivas de la región promotora de END1 hemos generado y analizado cuatro construcciones en las que se eliminaron de diferentes contextos de la secuencia 5' de END1 fragmentos internos que contenían posibles elementos reguladores de la expresión. 


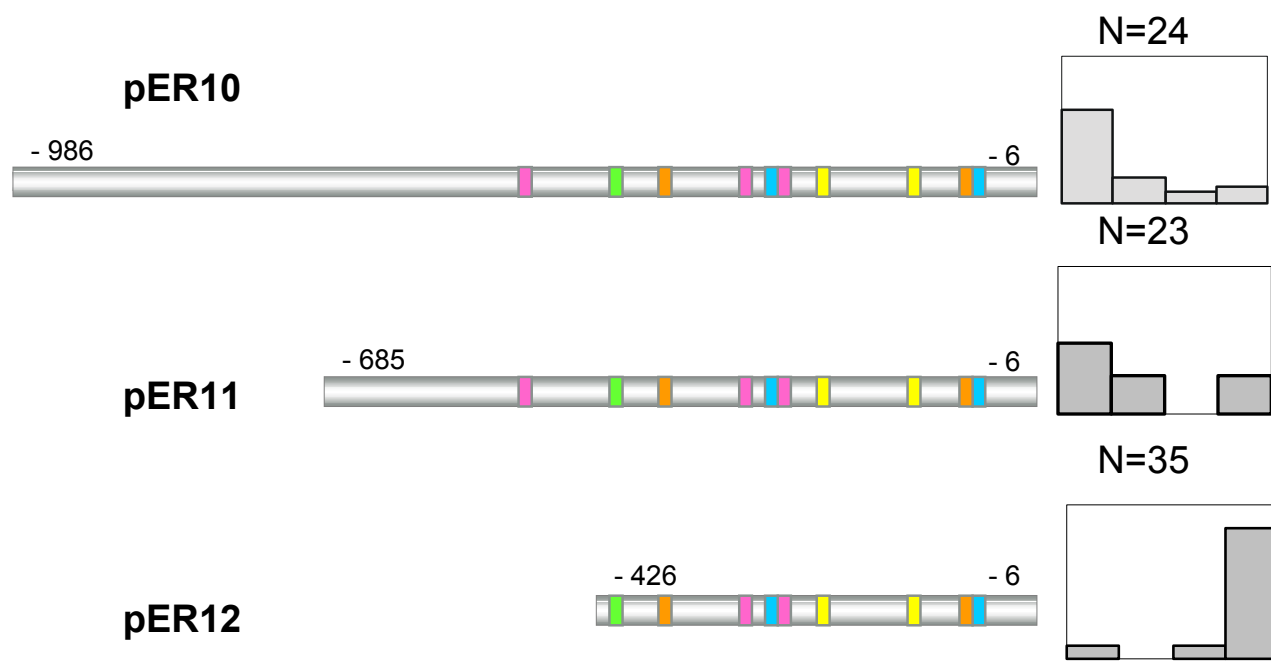

pER13

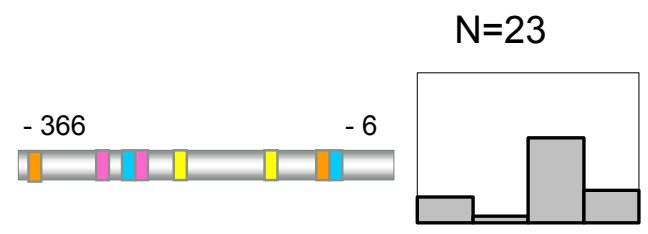

pER14

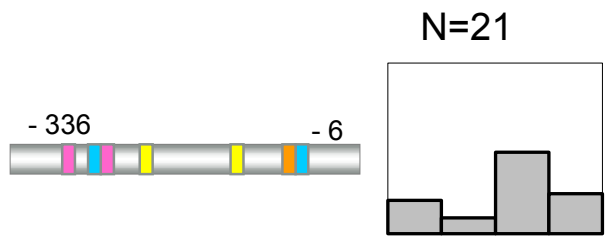

pER15

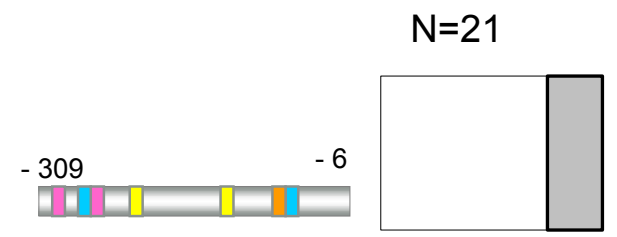

\footnotetext{
LEYENDA

CCAAT

CAAT

Secuencias distales generales de Eucariotas

TATA Posibles cajas TATA

C $(A)_{6 / 8}$, "GTCAAAA", "ACGTCA" Elementos presentes en promotores

$\square$ Posibles cajas CArG

de anteras
}

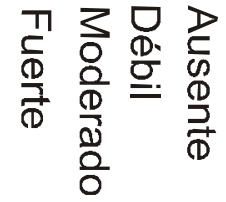

Figura 36. Construcciones con deleciones sucesivas del promotor de END1 y expresión de GUS en plantas transgénicas. Los gráficos a la derecha representan para cada construcción la distribución de los niveles de expresión para las mismas. El eje de las abcisas representa la intensidad de la señal GUS en las anteras, que se clasificó en fuerte, moderado, débil y ausente. En el eje de las ordenadas se representa el porcentaje de plantas que muestran los distintos niveles de expresión de GUS. N, número de plantas analizadas. 


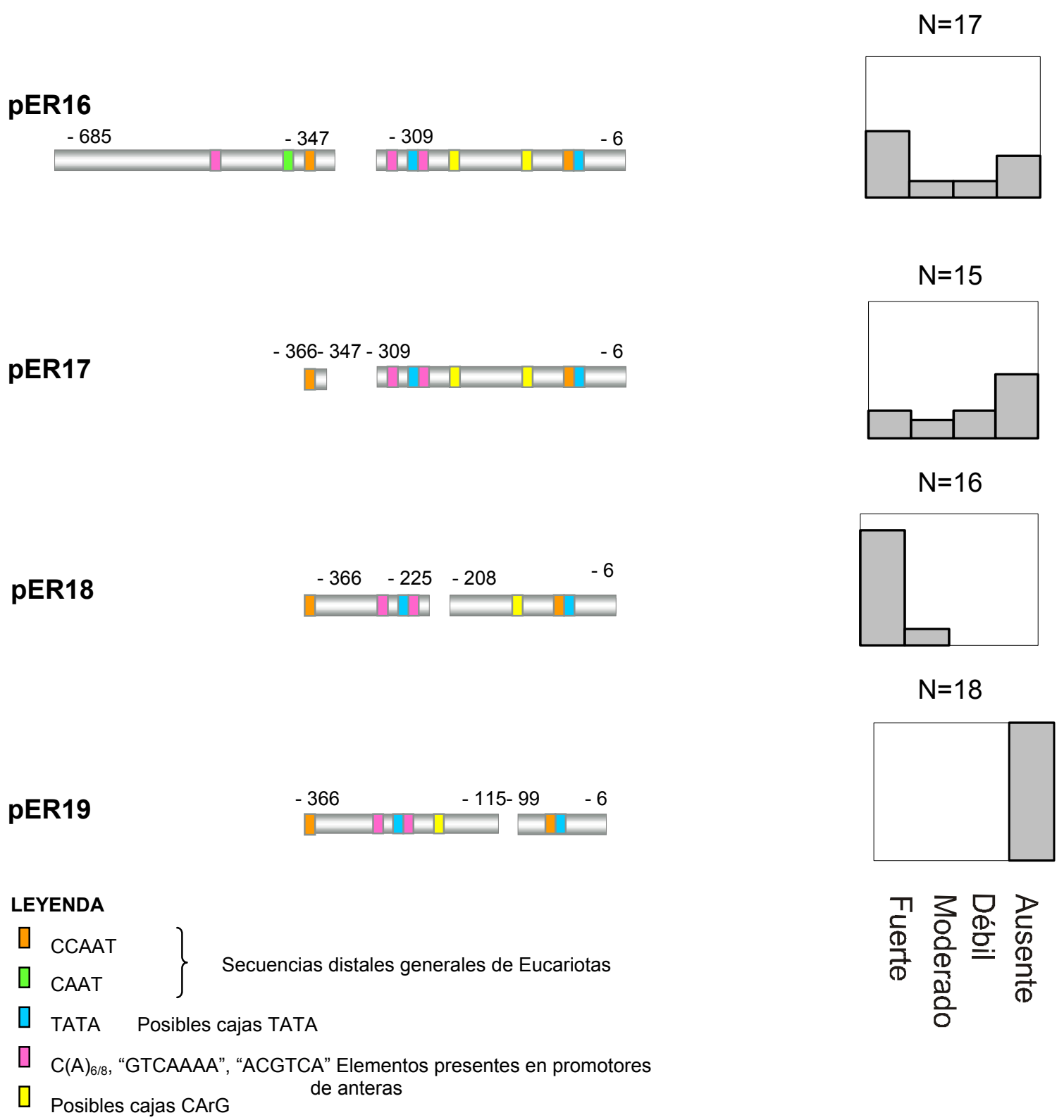

Figura 37. Construcciones con fragmentos de la región promotora de END1 con deleciones internas de posibles elementos reguladores. Los gráficos a la derecha de cada construcción representan los niveles de expresión del gen GUS en las diferentes líneas transgénicas. El eje de las abcisas representa la intensidad de la señal GUS en las anteras que se clasificó en fuerte, moderado, débil y ausente. En el eje de las ordenadas se representan los porcentajes de plantas que muestran los distintos niveles de expresión de GUS. N, número de plantas analizadas. 
El análisis de los resultados de las deleciones sucesivas de la región promotora de END1, mostró que el fragmento de -336 pb era la secuencia mínima que dirigía correctamente la expresión de END1. La expresión de GUS desaparecía completamente en las anteras de las plantas que contenían la deleción de -309 pb (construcción pER15), lo que indicaba los nucleótidos comprendidos entre -336 y -309 pb contenían algún elemento clave en la expresión de END1. Para analizar si estas secuencias eran imprescindibles para la expresión de END1, se eliminaron los nucleótidos comprendidos entre -347 y -309 en el contexto de $-685 \mathrm{pb}$ de la secuencia promotora creándose la construcción pER16. Esta misma deleción interna se realizó en un contexto más pequeño: el de -366 pb de la secuencia 5' de END1 (construcción pER17). Los resultados obtenidos para ambas construcciones aparecen representadas en la figura 37. La distribución del nivel de expresión de GUS entre las plantas transgénicas para estas construcciones eran similares a los de las transgénicas con las construcciones equivalentes en las que no se habían eliminado las secuencias comprendidas entre -347 y -309 (construcciones pER11 y pER13, respectivamente). Esto sugiere que en ambos contextos existe un elemento que suple la función de la región eliminada.

Para comprobar si las posibles cajas CArG (motivo CArG1 y motivo CArG2) encontradas en la secuencia 5' de END1 tenían algún efecto en la expresión del gen GUS, se generaron otras dos construcciones en las que se eliminaron dichas cajas del contexto de $-366 \mathrm{pb}$ de la región promotora (construcciones pER18 y pER19, respectivamente). En la primera de ellas se eliminó la secuencia entre -225 y -208, en la que se encuentra el motivo CArG 1. En las plantas transgénicas para esa construcción se observó un aumento significativo en los niveles de expresión del gen GUS (Figura 37) respecto a las transgénicas para la construcción 366/-6 (pER13). Por último, ninguna de las plantas transformadas con la construcción pER19, en la que se eliminaron los nucleótidos comprendidos entre -114 y -100 donde se encuentra el motivo CArG 2, mostraron actividad $\beta$ - glucuronidasa (Figura 37). Esto indica que el motivo CArG 2 es esencial para la expresión de END1 al menos dentro del contexto del promotor $-366 /-6$. 
DISCUSIÓN 

Previamente en nuestro laboratorio se aisló y caracterizó el gen END1 de guisante, que se expresa sólo en anteras a lo largo del desarrollo floral desde estadios tempranos del desarrollo. Durante este proceso el transcrito de END1 y la proteína que codifica se expresan en las líneas celulares que darán lugar a la epidermis, el endotecio, la capa intermedia y el tejido conectivo. También se detectó la expresión de END1 en esos mismos tejidos una vez desarrollados (Gómez, 2000; Gómez et al., 2004). Se vio que la región promotora de este gen (-2736/-6) es capaz de dirigir la expresión específica del gen foráneo GUS a las anteras de plantas de Arabidopsis thaliana, Nicotiana tabacum y Lycopersicon esculentum, siendo su distribución espacial y temporal similar a la de END1 en anteras de guisante (Gómez, 2000; Gómez et al., 2004).

Por otra parte, en el análisis informático de su secuencia nucleotídica se detectaron posibles motivos reguladores dentro de los cuales se encuentran dos posibles cajas CArG. Una de ellas (Motivo CArG 2) merecía especial atención pues se ajusta casi completamente a la secuencia consenso de las cajas CArG y las secuencias que lo flanquean son prácticamente las mismas que reconoce la proteína MADS-box codificada por el gen $A G$ de Arabidopsis (Huang et al., 1993).

Esta especificidad que confería el promotor de END1 para la expresión de un gen foráneo en las anteras ofrecía la posibilidad de utilizarlo, fusionándolo a un gen citotóxico, como una herramienta biotecnológica para la obtención de plantas transgénicas androestériles. En las anteras de estas plantas se podría estudiar, además, el efecto de la destrucción selectiva de los tipos celulares donde se produce la expresión del transgén en la diferenciación de las capas celulares contiguas. En el caso particular del tomate, las plantas transgénicas generadas también servirían para analizar la posible relación en este especie, entre androesterilidad y desarrollo partenocárpico del fruto. Así mismo, nos pareció de interés identificar las secuencias que representan elementos reguladores en cis del promotor de END1. Para esto se han llevado a cabo experimentos donde se ha analizado la funcionalidad de construcciones con distintos fragmentos de dicho promotor.

De manera general, los resultados presentados en este trabajo muestran que la región 5' del gen END1 (-2736/-6) dirige la expresión del gen citotóxico barnasa específicamente a las anteras de las plantas modelo $A$. thaliana y tabaco, así como a una planta de interés agronómico: el tomate. La expresión de la barnasa en los tejidos donde END1 es activo trajo como consecuencia la androesterilidad de estas plantas. En el caso de las plantas transgénicas de tomate, se produjo además el desarrollo de frutos partenocárpicos. Con el análisis funcional del promotor de END1 hemos mostrado que con aproximadamente una décima parte de su región 5' (-336/-6) se dirige la expresión del gen GUS a las anteras de Arabidopsis thaliana con un patrón similar al que muestra el mRNA de END1 en anteras de 
guisante. Por otra parte, nuestros resultados apoyan la hipótesis de que el gen END1 puede ser una diana directa de los genes MADS-box responsables de las funciones $\mathrm{B}$ y $\mathrm{C}$.

\section{EXPRESIÓN DEL TRANSGÉN END1::BARNASA EN PLANTAS TRANSGÉNICAS}

\subsection{Androesterilidad en plantas transgénicas}

La mayoría de las plantas transgénicas END1::barnasa generadas en este trabajo no produjeron granos de polen viable, por lo que fueron androestériles. Esto ocurrió como consecuencia de la expresión de la ribonucleasa barnasa específicamente en las anteras de las plantas transformadas. La presencia de la ribonucleasa en cualquier otro tipo celular podría haber alterado el desarrollo vegetativo y/o floral. No obstante, a pesar de la androesterilidad no se observó ninguna otra alteración fenotípica en las plantas transgénicas.

Las anteras transgénicas de Arabidopsis eran estructuras con forma de gancho y las transgénicas de tabaco eran de color marrón oscuro semejantes a puntas de flecha. Estaban sustentadas por filamentos de reducido tamaño, fenómeno asociado comúnmente con esterilidad masculina o fertilidad reducida. Este efecto ha sido observado en varias líneas estériles masculinas de colza (Brassica napus L.), donde la reducción del filamento se relacionó con el detenimiento en la microsporogénesis (Theis y Robblelen, 1990). Mariani et al. (1990) y Denis et al. (1993) observaron anteras con filamentos cortos en las plantas androestériles TA29::barnasa de tabaco y colza y en las plantas de tabaco apg::barnasa, respectivamente.

Las anteras de plantas END1::barnasa de tomate (cv. Micro-Tom) estaban malformadas. El grado de malformación variaba entre las diferentes líneas transgénicas. En una flor silvestre de tomate, los estambres forman un cono estaminal alrededor del estilo (Brukhin et al., 2003). De manera general, las anteras transgénicas de tomate eran más estrechas de lo normal, lo que hacía que fuese mayor la separación entre ellas e impedía que se mantuviese fusionado el cono estaminal. Las anteras de fenotipo más severo no llegaron apenas a formar sus tejidos, por lo que el estilo, que en anteras silvestres está oculto por el cono estaminal, se podía observar a simple vista. Independientemente del fenotipo mostrado por las anteras, ninguna produjo granos de polen viable con capacidad germinativa.

Se realizaron secciones transversales de anteras de Arabidopsis incluidas en resina o parafina en diferentes estadios del desarrollo para detectar cuando comenzaban a aparecer las diferencias histológicas con las anteras silvestres y determinar los tipos celulares que fueron afectados por la acción de la ribonucleasa. El efecto de la barnasa se observa en las 
anteras transgénicas de Arabidopsis desde los primeros estadios del desarrollo. Comienza cuando la antera es un primordio de células indiferenciadas y continúa observándose a lo largo del desarrollo de la misma. Las anteras transgénicas de Arabidopsis mostraron una organización celular interna similar a una antera silvestre en ningún estadio de desarrollo. En el último estadio analizado, se observó una capa de células epidérmicas rodeando algunas células parenquimáticas del tejido conectivo. Se formó un único saco polínico y este era deforme y contenía en su interior células atrofiadas del tapetum y de la capa intermedia. Estos tejidos rodeaban a una especie de material amorfo en lugar de microsporas libres. Este fenotipo es similar al que presenta el mutante de Arabidopsis undeveloped anther. Este gen participa en el control del desarrollo temprano de la antera, después de la especificación del primordio de estambre (Sanders et al., 1999).

Este mismo tipo de estudio comparativo se realizó también en cinco estadios representativos del desarrollo de anteras silvestres y transgénicas de tomate. Los resultados del mismo mostraron, al igual que en Arabidopsis, que las diferencias histológicas aparecían desde estadios de desarrollo muy tempranos y se mantenían a lo largo del desarrollo de la antera. Al final del programa de desarrollo, la antera transgénica era de menor tamaño, su morfología era distinta a la de una antera silvestre y en su interior se observaba un tejido conectivo colapsado y una estructura amorfa, en lugar de los tejidos reproductivos especializados. Este efecto fue similar al que presenta la antera de la planta trasgénica de tabaco TAB1 observada por microscopía óptica.

Se han llevado a cabo diferentes estrategias de ablación genética donde se destruye selectivamente un tipo celular específico y se identifica el efecto que ocasiona su pérdida en la diferenciación de las células contiguas. Para obtener una eficiente ablación genética es crucial disponer de un gen citotóxico que induzca la muerte celular y de un promotor que controle la expresión espacio-temporal de dicho gen. La ablación específica del tapetum utilizando dos promotores, el promotor TA29 de tabaco y el promotor APG de Arabidopsis junto con el gen barnasa, permitió descubrir que el tapetum es un tejido fundamental para el normal desarrollo de los granos de polen antes de que se disgreguen las tétradas en microsporas. (Mariani et al., 1990; Roberts et al., 1995). Además se demostró que las células tapetales funcionaban autónomamente y que no se requiere su presencia para la función y/o degeneración de otros tipos celulares de la antera durante la fase 2 de desarrollo (Koltunow et al., 1990; Mariani et al., 1990). Beals y Goldberg (1997) demostraron mediante ablación de diferentes tejidos de la antera combinando cuatro promotores distintos (TA29, TA20 y TA12 de tabaco y el promotor del gen de la lectina de soja) que el proceso de dehiscencia depende tan solo de un estomio funcional.

La expresión que confiere el promotor de END1 en guisante es distinta a la expresión de otros promotores previamente empleados en técnicas de ablación celular para producir 
androesterilidad. Estos promotores se expresan en tapetum o microsporas. El tapetum es un tejido glandular que produce enzimas, nutrientes y materiales estructurales esenciales para la microsporogénesis (Carniel, 1963). Se ha demostrado que la ablación de este tejido antes de la disgregación de las tétradas de miscrosporas influye negativamente en la formación de los granos de polen. END1 comienza a expresarse en el primordio de antera de guisante, en aquellas líneas celulares que darán lugar a la epidermis, conectivo y además en las células parietales primarias (Gómez, 2000; Gómez et al., 2004). Las células parietales primarias dan lugar a tres capas concéntricas que constituirán el endotecio, la capa intermedia y el tapetum más externo (Figura $6 \mathrm{E}$ ). En estadios de desarrollo más avanzados, END1 se expresa en los tejidos derivados de las células parietales menos en el tapetum. Además se observa su expresión en los tejidos epidermis y conectivo. Los tejidos donde se halla la expresión de END1 funcionan en la antera fundamentalmente como tejidos de estructura y soporte y no tienen una interacción directa con el desarrollo de los granos de polen.

En las plantas END1::barnasa la formación de los granos de polen está seriamente afectada. Si el promotor de END1 dirigiese la expresión del gen barnasa en plantas heterólogas de la misma forma que lo hace con el gen endógeno en guisante, la expresión del gen citotóxico afectaría a las células parietales primarias. En las plantas END1::barnasa la pérdida de las células parietales primarias podría estar afectando la diferenciación de las células esporógenas, contiguas en el territorio del futuro microsporangio o saco polínico. Por otra parte, la misma expresión de la barnasa en las células del tejido conectivo provocaría la muerte de las mismas produciendo el colapso del tejido. Esto posiblemente es la causa de la disminución del tamaño y cambios en la morfología de las anteras de las plantas transgénicas.

El uso del promotor de END1 junto con el de otros promotores específicos del desarrollo temprano de la antera, dirigiendo la expresión de los genes barnasa y barstar, podría permitir una mejor caracterización de las líneas celulares que dan origen a los tejidos de una antera y comprobar la función de las interacciones célula-célula. De especial interés sería contar con un promotor que se expresase en aquellas células que dan lugar a la epidermis y al tejido conectivo. Esto permitiría transformar plantas con dos construcciones: una constituida por este promotor hipotético y el gen barstar y otra donde el promotor de END1 dirigiese la expresión del gen barnasa. De esta manera, en las anteras de las plantas transgénicas para ambas construcciones, ocurriría la ablación celular sólo en las células parietales primarias pues la acción de la barnasa en los restantes tejidos donde END1 es activo estaría bloqueada por la acción del gen barstar. El análisis histológico de estas anteras podría revelarnos el papel de las células parietales primarias en el desarrollo de la antera. Si la pérdida de las células parietales primarias formadas durante los primeros 
estadios del desarrollo de la antera afectase la diferenciación de las células esporógenas, se confirmaría nuestra hipótesis y habría una clara evidencia de la importancia de las interacciones célula-célula durante los procesos de diferenciación de la antera.

La ingeniería genética se ha usado para generar plantas androestériles de tabaco, colza (Mariani et al., 1990), trigo (De Bolck et al., 1997), y col (Lee et al., 2003). El sistema usado para producir androesterilidad en estos casos se basa en el uso de promotores de genes implicados en el desarrollo del polen que dirigen la expresión de genes citotóxicos al tapetum de la antera. El sistema TA29::barnasa es el más usado a nivel comercial para generar plantas androestériles en la producción de semillas híbridas. Se han usado otros promotores de genes específicos de tapetum de arroz (pE1, pT72) y de maíz (pca55), para dirigir la expresión del gen barnasa a las anteras de plantas de trigo (De Block et al., 1997). Recientemente, se han generado plantas androestériles de col fusionando el promotor BcA9 (promotor específico de tapetum de Brassica campestris L. ssp. pekinensis homólogo al gen A9 de Arabidopsis) al gen citotóxico DTA (Lee et al., 2003). El promotor de END1, podría ser una vía alternativa para generar plantas androestériles de manera eficiente en diferentes especies de plantas.

Otra característica observada en las plantas estériles masculinas END1::barnasa de Arabidopsis y tabaco fue la actividad prolongada del meristemo inflorescente. Al comparar las plantas transgénicas de $A$. thaliana con plantas silvestres se podía observar un aumento en el porte de las mismas así como en el número de flores. La planta transgénica TAB 1 de tabaco estuvo produciendo flores por un período aproximado de 24 meses.

En mutantes estériles de $A$. thaliana se observó un incremento en el número de ramas infloresecentes y flores por rama en comparación con las de una planta silvestre. Esto condujo a la hipótesis de que el desarrollo normal de los frutos controla la capacidad de los meristemos inflorescentes de producir flores adicionales (Hensel et al., 1994). Antiguamente ya se postulaba que la senescencia de las plantas estaba asociada con la reproducción y esto ocurría como una consecuencia de la desviación de nutrientes de las estructuras vegetativas a las reproductivas. Actualmente, se han propuesto dos modelos básicos para explicar los mecanismos para el "detenimiento" apical: a) el modelo de limitación de recursos, y b) el modelo del factor inhibitorio (Hensel et al., 1994). En el modelo de limitación de recursos se plantea que bajo condiciones de competencia entre el desarrollo de las semillas y los meristemos disminuyen los niveles de nutrientes, hormonas o factores de crecimiento destinados a estos últimos. El otro modelo estipula que una señal química producida por los frutos o semillas es la responsable de la supresión de la actividad de los meristemos cuando el nivel del inhibidor excede un umbral específico en el ápice. 


\subsection{Eficiencia del promotor de END1 para la producción de plantas androestériles}

Uno de los aspectos más importantes a tener en cuenta en la producción comercial de semilla híbrida es obtener semillas puras no contaminadas con las semillas producto de la autopolinización. Se han empleado tradicionalmente diferentes métodos que previenen el autocruce. Se encuentran entre ellos, la emasculación manual de las líneas parentales femeninas, el uso de gametocidas que destruyen el polen, así como el aprovechamiento de plantas autoincompatibles o con esterilidad masculina citoplásmica. Todos estos sistemas que han sido explotados para la producción comercial de semillas híbridas tienen algunas limitaciones y no existen para todos los cultivos. Es por ello que ha despertado un gran interés el desarrollo de nuevas estrategias basadas en la Biología Molecular. Nuestro método genético para obtener androesterilidad ha sido analizado para evaluar su eficiencia. En este caso, con el término eficiencia nos referimos a la capacidad del transgén END1::barnasa de bloquear el desarrollo de polen viable en todas las flores de una misma planta y así impedir la autopolinización y el consecuente desarrollo de los frutos. Al contabilizar las silicuas producidas en relación al número de posiciones florales en plantas END1::barnasa de Arabidopsis, pudimos comprobar que, de cuatro líneas independientes analizadas, dos de ellas no formaron frutos en ninguna de sus posiciones florales. Con esto se demuestra que es posible seleccionar líneas transgénicas END1::barnasa con un 100\% de eficiencia. Esto significa que en este tipo de línea se puede confiar en que todos los frutos producidos serán producto de la polinización cruzada con polen del parental masculino deseado para la obtención de la variedad híbrida.

Las semillas de algunas de las líneas END1::barnasa de Arabidopsis mostraron una reducción en su capacidad de germinación. Así, la descendencia del cruce $\mathrm{B}_{14} \times$ silvestre presentó un $70 \%$ de germinación. Sin embargo, el análisis de varias líneas transgénicas distintas mostró que la mayoría de las líneas END1::barnasa producen semillas que germinan y dan lugar a plantas que mantienen el carácter de androesterilidad. Además, las plantas resultantes tienen un desarrollo vegetativo y floral normal. Esto muestra que es posible seleccionar líneas transgénicas que puedan ser utilizadas con alta eficiencia para la producción a gran escala de la línea androestéril en el proceso de obtención de variedades híbridas.

\subsection{Restauración de la fertilidad en plantas estériles END1::barnasa}

La inducción de androesterilidad nuclear por la expresión en la antera de un gen citotóxico, fue la primera estrategia molecular que se utilizó para la obtención de esterilidad masculina en plantas transgénicas (Mariani et al., 1990). En un trabajo posterior se mostró que el 
cruce de plantas de colza estériles masculinas TA29::barnasa con plantas fértiles que contenían el transgén TA29::barstar producía una progenie, con ambos genes, que era fértil (Mariani et al., 1992). Los transgenes TA29::barnasa y TA29::barstar se coexpresan en anteras de la progenie fértil, lo que indica que el transgén TA29::barstar era un supresor dominante de la actividad citotóxica del transgén TA29::barnasa. La restauración de la fertilidad se debía a la formación del complejo equimolar estable barnasa-barstar, específicamente en el tapetum. Esta disponibilidad de genes generadores de esterilidad masculina y sus respectivos genes restauradores facilita el desarrollo de estrategias biotecnológicas para los sistemas de producción de semillas híbridas, ya que en muchos cultivos donde el producto de interés es el fruto es deseable la restauración de la fertilidad en la progenie híbrida para maximizar la polinización y el consecuente rendimiento.

Los experimentos encaminados a la restauración de la fertilidad por la expresión del transgén END1::barstar en plantas estériles END1::barnasa resultaron parcialmente efectivos. En la descendencia del cruce entre una planta de la línea hemicigota estéril END1::barnasa 8 con una planta homocigota de la línea END1::barstar 14 las plantas recuperaron la fertilidad aunque no hasta el nivel de las plantas silvestres. Dichas plantas produjeron fruto en alguna de sus posiciones florales pero en ocasiones éstos eran más pequeños y de menor grosor que los frutos de las plantas silvestres. Sin embargo, los estambres de estas plantas poseían filamentos que prácticamente alcanzaban el estigma del carpelo y anteras más parecidas a las de plantas silvestres que a las de las plantas usadas como parental femenino. Esto demuestra que, aunque parcialmente, el transgén END1::barstar fue capaz de contrarrestar la acción destructiva de la barnasa.

Para eliminar el efecto tóxico que provoca la expresión de la barnasa, el transgén END1::barstar debería ser capaz de generar un exceso de moléculas de barstar para que todas las moléculas de barnasa formen parte del complejo no tóxico barnasa-barstar. Presumiblemente, en nuestros experimentos las plantas que contenían ambos transgenes no produjeron una cantidad suficiente del inhibidor en las anteras. Posiblemente para identificar una línea END1::barstar eficiente para la restauración de la fertilidad, se deberían realizar cruces entre varias líneas estériles (END1::barnasa) y varias líneas restauradoras (END1::barstar) y seleccionar aquella combinación que resultase más efectiva. Mariani et al. (1992), encontraron seis combinaciones efectivas de los nueve cruces realizados entre cuatro transformantes de una copia TA29::barnasa con cuatro líneas heterocigotas de una copia TA29:barstar. 


\subsection{Efectividad del promotor END1 de guisante en otras especies}

En colaboración con la empresa Newbiotechnic SA (NBT) y Michael Wallbrawn/Gabi Krczad del Centrum Grüne Gentechnik de Alemania, se han transformado plantas de colza (Brassica napus) con la construcción pBI-END1::barnasa-barstar. Las plantas obtenidas eran androestériles y muestran características similares a las descritas en nuestros resultados. Paralelamente, en colaboración con NBT y Joaquima Messeguer (IRTA, Cabrils, Barcelona) se ha realizado la transformación de arroz con una construcción que contenía el promotor de END1 dirigiendo la expresión del gen marcador GUS. Para esto se ha utilizado el plásmido pCAMBIA, uno de los plásmidos más eficientes en la transformación de monocotiledóneas. Las plantas de arroz mostraron actividad $\beta$-glucuronidasa en las anteras y además se detectó una expresión inespecífica en otros órganos florales. Con la transformación de trigo con una construcción equivalente, pero que contenía además el intrón de la ubiquitina del maíz como elemento generador de altos niveles de expresión en monocotiledóneas (Christensen y Quail, 1996), se obtuvieron también plantas que mostraron actividad $\beta$-glucuronidasa en las anteras. Esto último se ha realizado en colaboración con la empresa NBT y Francisco Barro de la Universidad de Córdoba. Estos resultados, junto a los presentados en este trabajo, muestran que el promotor de END1 dirige eficientemente la expresión a las anteras de una amplia variedad de plantas dicotiledóneas y monocotiledóneas. Por ello, este promotor podría ser muy útil en los programas de obtención de semilla híbrida de diferentes cultivos de interés agronómico.

\subsection{Desarrollo partenocárpico de frutos en plantas END1::barnasa de tomate (cv. Micro-Tom)}

El mutante partenocárpico de tomate pat se caracteriza por los defectos en las anteras y los óvulos. Como los defectos en el mutante involucran la identidad y el desarrollo de los órganos florales (anteras carpeloides), esta mutación fue tentativamente adscrita a un gen homeótico con efecto pleiotrópico tardío de partenocarpia (Mazzucato et al., 1998). La asociación de transformaciones homeóticas con el desarrollo de frutos partenocárpicos se ha observado en plantas transgénicas de tomate que expresan construcciones antisentido de genes homeóticos de esta especie (Lifschitz et al., 1993; Pnueli, et al., 1994; AmpomahDwamena et al., 2002). Las alteraciones morfológicas en estas plantas afectaron de manera general los tres verticilos internos de la flor provocando, entre otros defectos, esterilidad masculina y femenina. En el mutante de tomate stamenless se producen conversiones homeóticas similares a las que producen la mutación de los genes de clase $B$ en Arabidopsis y Antirrhinum. Este mutante tiene como principal característica la ausencia 
de estambres (Gómez et al., 1999). La mutación del gen de manzano MdPI, homólogo al gen $P I$ de Arabidopsis, produjo flores que no tenían ni pétalos ni estambres y en su lugar se desarrollaron sépalos y carpelos, respectivamente (Yao et al., 2001). Las flores de ambos mutantes produjeron además el desarrollo partenocárpico del fruto (Gómez et al., 1999; Yao et al., 2001).

El estudio de los fenotipos de las plantas en las que por la mutación del gen pat, o por la mutación o expresión antisentido de genes homeóticos florales se desarrollan frutos partenocárpicos, reveló un defecto común a todas. Este defecto fue la malformación en los estambres, que conllevó a la esterilidad masculina. A partir de la hipótesis que plantea que en el mutante pat la partenocarpia podría ser un defecto inducido de las malformaciones en las anteras y los óvulos (Mazzucato et al., 1999), nos cuestionamos si la interferencia en el desarrollo de las anteras conduciría al crecimiento autónomo del ovario de tomate. Para ello contábamos con las plantas transgénicas END1::barnasa, de las que se esperaba fuesen androestériles como consecuencia de la ablación de tejidos específicos de la antera.

Las plantas transgénicas de tomate END1::barnasa mostraban alteraciones morfológicas en los estambres. Estas alteraciones provocaron que en algunas plantas no se produjeran granos de polen y que en otras fuesen prácticamente inviables y con aptitud germinativa casi nula. Todas las plantas transgénicas de tomate produjeron frutos. El análisis de los mismo reveló la ausencia de semillas, mostrando que su formación se había llevado a cabo por partenocarpia, una vía alternativa al cuajado y desarrollo normal del fruto, donde el ovario crece sin la formación de semillas (Lukyanenko, 1991). También se observó que el desarrollo de los frutos en las plantas transgénicas comenzó antes de que en las plantas silvestres. Los ovarios transgénicos de flores de día 0 (antesis) alcanzaban un tamaño mayor que los de las flores silvestres en el mismo estadio de desarrollo. Este mismo efecto se observó en mutantes pat, donde el crecimiento del ovario comienza precozmente, en estadio de pre-antesis (Mazzucato et al., 1998).

El hecho de que en las flores END1::barnasa el ovario se desarrolle partenocárpicamente, sugiere que la partenocarpia que acompaña a las mutaciones homeóticas que, entre varios efectos, causan malformaciones en los estambres y esterilidad masculina, podrían deberse a las alteraciones que estas mutaciones causan en el desarrollo de las anteras más que a que los correspondientes genes controlen de manera directa el desarrollo del ovario. Por lo tanto, con estos resultados se apoya la hipótesis de que la partenocarpia podría ser un efecto inducido de las malformaciones en los estambres que impiden que tenga lugar la polinización. Todos estos resultados sugieren la idea de que las anteras tienen un papel regulador en el proceso de desarrollo del ovario a fruto.

Las anteras, desde estadios tempranos de su desarrollo, podrían generar una señal represora hacia el ovario inhibiendo su tendencia natural de crecer como fruto. Esta 
regulación del desarrollo del carpelo por los estambres estaría bloqueada en el caso de las plantas transgénicas en cuestión, las cuales muestran cuajado del fruto en ausencia de polinización. En esta hipótesis habría que contemplar que la represión del crecimiento autónomo del ovario por las anteras sólo tiene lugar en estadios tempranos del desarrollo. En estadios posteriores el ovario adquiriría otra estrategia: no desarrollarse a no ser que reciba un estímulo positivo por parte de la polinización. Esto explicaría que al emascular plantas de tomate no se produzcan frutos. La emasculación sólo se puede llevar a cabo, en la práctica, cuando las anteras han alcanzado un estadio de desarrollo en el que están formados todas sus células y tejidos especializados. Además, la emasculación es un factor externo que ocurre a espaldas de las señales internas de la planta, que ha seguido su pauta de desarrollo normal: utilizar las vías que la conducen a la polinización y fertilización para el desarrollo de los frutos y las semillas.

La partenocarpia genética está relacionada con la acumulación precoz de auxinas y GAs en el ovario. De hecho, la aplicación exógena de auxinas o GAs a un ovario de tomate no polinizado, imita el efecto de la polinización provocando generalmente el desarrollo partenocárpico del fruto. Se ha corroborado esta relación con diversos experimentos (Mapelli et al., 1979; Sawhney y Greyson, 1973; Fos et al., 2000; Jacobsen y Olszewski, 1996) que se comentan en el apartado 4 de la Introducción.

La aplicación de paclobutrazol (inhibidor de la síntesis de giberelinas) a los ovarios no polinizados de algunas flores de plantas END1::barnasa inhibió el desarrollo de los frutos y esto se revertió al aplicar paclobutrazol más $\mathrm{GA}_{3}$. Esta observación sugiere que la señal represora que ejercen las anteras en el desarrollo del ovario, podría ser un represor de síntesis de giberelinas en el mismo. En las plantas transgénicas de tomate END1::barnasa en cuestión, esta señal represora estaría ausente, permitiendo la síntesis de GAs en el ovario y consecuentemente el desarrollo de los frutos sin semillas.

La partenocarpia genética ha sido considerada un carácter útil para el desarrollo de cultivos que pueden producir frutos bajo condiciones ambientales adversas que inhiban la polinización y/o fertilización. La partenocarpia podría resolver el problema de la baja viabilidad del polen y las dificultades de su liberación bajo condiciones de baja intensidad de luz y bajas temperaturas en los invernaderos (George et al., 1994). La presencia de semillas en los tomates es un aspecto no atractivo del fruto para los procesos de preparación de alimentos a escala industrial que tienen como base el tomate, como por ejemplo el puré, sopas, zumos o salsas, donde es necesario eliminar las semillas por tamizado antes de triturar o hervir la mezcla (Varoquaux et al., 2000).

La ingeniería genética ofrece la posibilidad de introducir el carácter de partenocarpia en cualquier especie de interés agronómico (Rotino et al., 1997). Hasta el momento la tecnología para la producción de frutos partenocárpicos ha consistido fundamentalmente en 
el uso del transgén DefH9-iaaM, que contiene la región codificante del gen iaaM de Pseudomonas syringae pv. savastanoi bajo el control del promotor específico de óvulo DefH9, de Antirrhinum majus (Rotino et al., 1997). El gen iaaM codifica una enzima (triptófano monooxigenasa) que convierte el triptófano a indolacetamida (Yamada et al., 1985), la que posteriomente se convierte por la acción de las hidrolasas de la planta (Kawaguchi et al., 1991) en IAA, la principal forma de auxina en las plantas. La expresión del trasgén DefH9-iaaM para producir el desarrollo de frutos partenocárpicos se ha ensayado con éxito en tabaco, berenjena (Rotino et al., 1997), tomate (variedad tipo cherry) (Ficcadenti et al., 1999) y en tres variedades de rosáceas (Mazzetti et al., 2004). La introducción de este transgén en las plantas de tomate de la variedad UC82 causó la producción de frutos partenocárpicos pero éstos mostraban malformaciones (Spena et al., 1999). Las malformaciones fueron similares a las causadas por la aplicación de un exceso de auxina exógena en cultivos de tomate (Schwabe y Mills, 1981). Por ello, las deformidades en los frutos transgénicos se interpretaron como el resultado de un exceso de auxinas causado por el transgén DefH9-iaaM o a una alta sensibilidad de los frutos a estas hormonas. Este problema fue resuelto mediante el desarrollo del transgén DefH9-RI-iaaM que contiene un promotor DefH9 modificado que causa una reducción de la transcripción del mRNA de iaaM (Pandolfini et al., 2002). También se han obtenido plantas transgénicas de tomate que desarrollan frutos partenocarpicos por la expresión de un transgén que contiene el gen rolB de Agrobacterium rhizogenes fusionado al promotor específico de ovario y fruto TPRP-F1 (Salts et al., 1991, 1992; Carmi et al., 2003). La sobrexpresión del gen rolB en plantas transgénicas de tabaco y patata causó alteraciones similares a las producidas mediante el tratamiento con auxinas (Schmulling et al., 1988; 1993). Aunque la función de este gen no está establecida, se ha postulado que ROLB afecta a la ruta de señalización de las auxinas (Nilsson y Olsson, 1997).

Nuestros resultados generan diversas perspectivas de trabajo futuras. Para las posibles aplicaciones biotecnológicas derivadas de la obtención de frutos partenocárpicos de tomate mediante la expresión del transgén END1::barnasa, deberíamos testar si este efecto ocurre también en otros cultivares de tomate. En estos momentos se está llevando a cabo la transformación genética de la variedad de tomate P73 con el transgén en cuestión. Con los resultados que se deriven de estos experimentos se comprobará si los efectos de la expresión del transgén END1::barnasa son extrapolables a otras variedades de tomate de interés comercial. Una ventaja adicional en la producción de frutos partenocárpicos de tomate mediante esta herramienta biotecnológica, es que las plantas transgénicas generadas no producen polen. Esto aliviaría la preocupación existente con respecto a la transferencia de transgenes a cultivos no transgénicos por polinización cruzada. 
Por otra parte, sería interesante estudiar el mecanismo molecular subyacente en el proceso de desarrollo de frutos partenocárpicos como consecuencia de la ablación temprana de tejidos de la antera que impidan el desarrollo de granos de polen viable.

\section{ANÁLISIS FUNCIONAL DEL PROMOTOR DE END1}

Un método que se utiliza para analizar el funcionamiento del promotor de un gen consiste en fusionar fragmentos de la secuencia promotora en cuestión a un gen marcador, tal como el gen uidA (GUS), e introducir dichas construcciones en el genoma de las plantas para estudiar el patrón de expresión que confieren estas construcciones. Este estudio proporciona información sobre los elementos reguladores en cis que determinan la expresión celular específica y la expresión temporal del gen en cuestión (Tebbut y Lonsdale, 1995).

Previamente se había mostrado que la región 5' de la secuencia genómica de END1 comprendida entre -1531/-6 pb era suficiente para dirigir la expresión espacial y temporal del gen END1 a las anteras de plantas diferentes del guisante: Arabidopsis thaliana, Nicotiana tabacum y Lycopersicon esculentum. La distribución espacio temporal del gen GUS en estas plantas es similar a la del mRNA mensajero y la proteína de END1 en las anteras del guisante (Gómez, 2000; Gómez et al., 2004). Por ello se consideró que las secuencias reguladoras de END1 se localizan en la región 5'. En general, los elementos en cis requeridos para la expresión de los genes se encuentran en las regiones 5', sin embargo, no es poco común localizar elementos de control en las secuencias 3' de un gen o en sus intrones (Dietrich et al., 1992; Larkin et al., 1993). Por ejemplo, secuencias presentes en el segundo intrón de $A G$ son esenciales para la regulación de la expresión de este gen de identidad de órgano de clase C (Sieburth y Meyerowitz, 1997; Deyholos y Sieburth, 2000). Por otra parte, para dirigir correctamente la expresión espacial y temporal del gen GL1 de Arabidopsis se necesitan 490 pb de la región 3' a la vez que la región 5' del mismo (Larkin et al., 1993).

Como se ha mencionado, el análisis informático de la región 5' del gen END1 puso de manifiesto la presencia de diversas secuencias con homología a diversos elementos reguladores encontrados en otros promotores de expresión específica en anteras. También mostró la existencia de posibles cajas CArG: ${ }^{-222}$ CCAACTCATGG $^{-212}$ (motivo CArG 1) y ${ }^{-103}$ CCCAAAATGG $^{-112}$ (Motivo CArG 2) (Gómez, 2000; Gómez et al., 2004). Las cajas CArG son elementos en cis a los que se unen los factores trascripcionales de la familia MADS-box cuya secuencia consenso puede ser descrita como 5'-CC(A/T) 6 GG-3' (Schwarz-Sommer et al., 1992; Huang et al., 1993; Shiraishi et al., 1993; Shore y Sharrocks, 1995). Los miembros de esta familia de factores transcripcionales que reciben 
tal nombre por contener un dominio conservado en la región $\mathrm{N}$-terminal, de una longitud de aproximadamente 60 aminoácidos, denominado caja MADS. La caja MADS es la región principalmente implicada en la unión a DNA in vitro y es importante, aunque no absolutamente esencial, para la dimerización (Schwarz- Sommer et al., 1990; Shore y Sharroks, 1995; Pellegrini y Richmond, 1995; Davies et al., 1996; Riechmann et al., 1996 a, b; Riechmann y Meyerowitz, 1997).

En este trabajo se ha realizado un análisis detallado de la región 5' del gen END1. Para este análisis se realizaron deleciones sucesivas de la región 5' del gen y los fragmentos resultantes se fusionaron transcripcionalmente al gen delator GUS (uidA). Con estas construcciones se transformaron plantas de $A$. thaliana y se estudió la expresión del gen uidA mediante el ensayo histoquímico de la actividad de la $\beta$-glucuronidasa. Las deleciones sucesivas $-986,-685,-426,-366$ y -336 dirigieron la expresión del gen GUS a las anteras de las plantas transformadas. En todos los casos esta actividad se observó desde estadios tempranos del desarrollo, en un patrón espacial y temporal similar a la construcción que contenía la región -1531/-6 de la secuencia 5’ de END1 (Gómez, 2000; Gómez et al., 2004).

No se observaron grandes diferencias entre la distribución de los niveles de expresión de GUS en las anteras de las plantas que contenían las deleciones -986 y -685 (construcciones pER10 y pER11, respectivamente) (Figura 38). Para ambas deleciones se observó que entre el 70 y el $80 \%$ de las plantas transgénicas analizadas mostraban expresión de GUS fuerte o moderado en las anteras. Esto sugiere que en la región entre 968 y -685 no deben existir elementos que jueguen un papel muy relevante en el control de la expresión de END1.

Sin embargo, la siguiente deleción, hasta el nucleótido -426 , condujo a una caída brusca en los niveles de expresión de GUS. Sólo aproximadamente el $5 \%$ de las plantas transformantes con esta construcción (-426/-6; construcción pER12) mostró un nivel fuerte de actividad GUS en las anteras, y la mayoría de las plantas no expresó GUS en absoluto (Figura 38). Puesto que esta caída brusca de actividad GUS aparecía en contradicción con los resultados que se obtuvieron para la siguiente deleción, que se discute a continuación, se volvió a generar por segunda vez tanto la construcción pER12 como las transgénicas para la misma. En ambos experimentos se obtuvieron esencialmente los mismos resultados. Esto sugiere la existencia de un elemento regulador positivo en las secuencias comprendidas entre -685 y -426 . En las plantas transformadas con la construcción correspondiente a la siguiente deleción (-366/-6; construcción pER13), se recuperó notablemente la expresión de GUS. En este caso, la mayoría de las plantas (aproximadamente el 80\%) mostró actividad GUS (Figura 38). Esto sugiere la presencia de un elemento regulador negativo en la región comprendida 
entre -426 y -366. La actividad de este elemento represor estaría enmascarada por la presencia de elementos positivos en la región anterior a -426 . La distribución de la expresión de GUS para la deleción de -366 (construcción pER14) se mantuvo similar para la siguiente deleción, -336 (Figura 38). Esto sugiere que los 31 nucleótidos comprendidos en las secuencias en que difieren ambas deleciones, no contienen elementos relevantes para la regulación de END1. Con la deleción de -309 (construcción pER15) desaparece completamente la actividad del promotor (Figura 38), lo que muestra que región entre 336 y -309 contiene elementos imprescindibles para la expresión del gen. Sin embargo, al eliminar esa región (-347 a -309) de los contextos de -685 ó -366 pb de la secuencia 5' (construcciones pER16 y pER17, respectivamente), se observaron niveles de expresión de GUS similares a los de sus construcciones equivalentes en las que no se habían realizado deleciones internas (construcciones pER11 y pER13) (Figura 38). Esto indica que en ambos contextos existen elementos que suplen la función de las secuencias eliminadas (-347 a -309).

En resumen, por un lado la comparación de las deleciones -336/-6 y -309/-6 muestran que en la región comprendidas entre -336 y -309 existen elementos claves para mantener la expresión de END1. Por otro lado, la recuperación de la expresión GUS para la construcción pER17, donde se eliminaron los nucleótidos comprendidos entre -347 y -309 en el contexto de -366, muestra que la secuencia entre -366 y -347 es capaz de suplir la pérdida de los elementos comprendidos entre -347 y -309 . Esto indica que estas dos regiones adyacentes (-366/-347 y -336/-309) contienen elementos redundantes con funciones clave en la expresión de END1.

Los resultados del análisis de las deleciones sucesivas del promotor de END1 revelan que la región de -336/-6 contiene los elementos requeridos para la expresión de GUS en las anteras de Arabidopsis desde estadios tempranos del desarrollo hasta la antesis. Los datos muestran que -336/-6 es la región definida de la secuencia 5' con capacidad para funcionar como un promotor mínimo para la correcta expresión espacial y temporal del gen. En esta región se concentran varios de los posibles motivos reguladores más importantes encontrados en el análisis informático de la secuencia de END1: tanto motivos presentes en otros promotores de antera como posibles sitios de unión a DNA de los factores de transcripción de tipo MADS-box. 


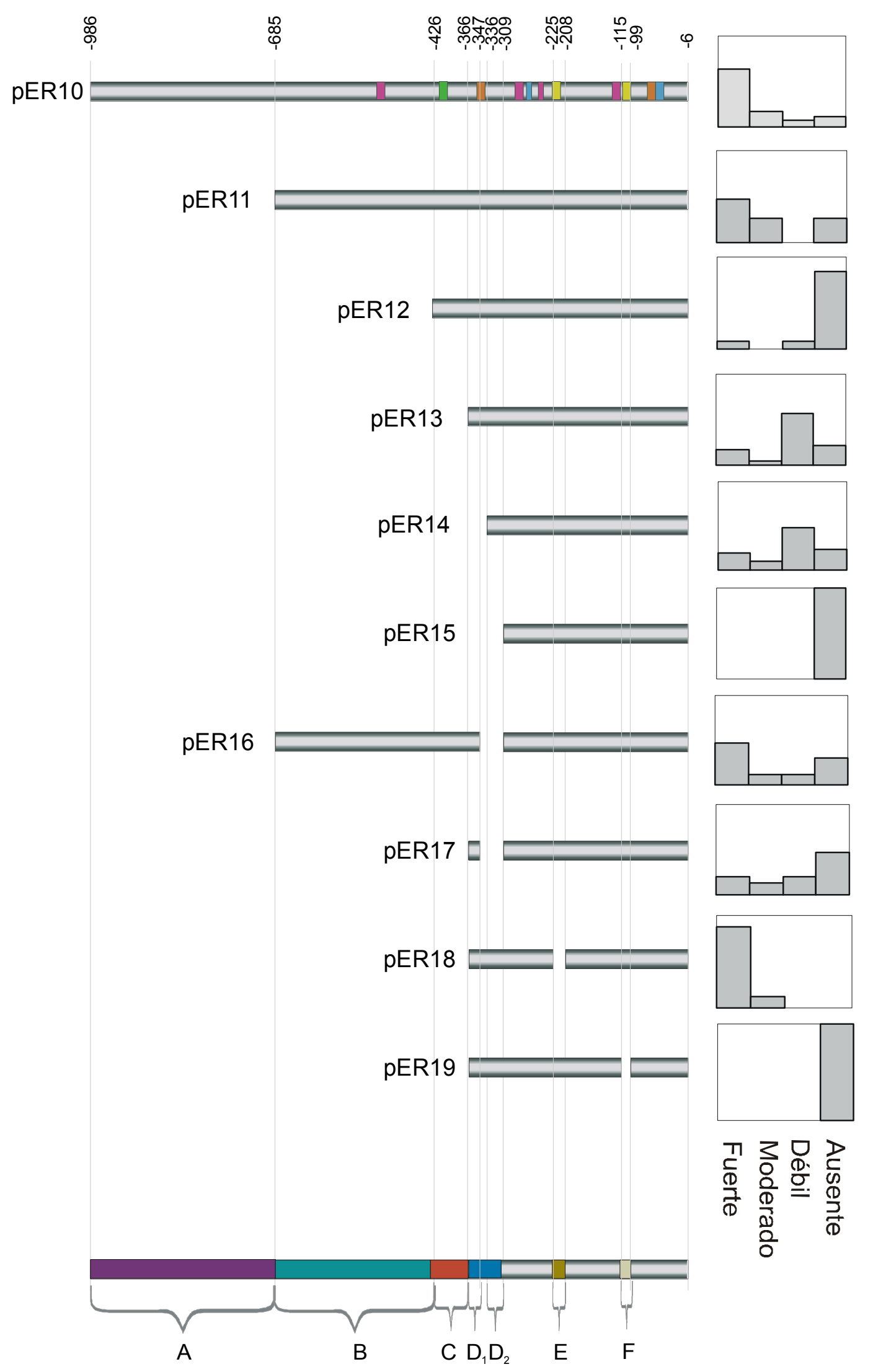

Figura 38. Resumen de los resultados del análisis funcional del promotor de END1. A la izquierda, se muestra un esquema de las construcciones utilizadas en el análisis funcional del promotor y, a la derecha, los gráficos donde se representa la distribución de los niveles de expresión de GUS en las anteras de las plantas transformadas con cada construcción. El eje de las abcisas representa la intensidad de la señal GUS, que se clasificó en fuerte, moderada débil y ausente. En el 
eje de las ordenadas se representa el porcentaje de plantas que muestran los distintos niveles de expresión de GUS. En el inferior de la figura se representa esquemáticamente el promotor de END1 donde se señalan diferentes dominios de expresión que se han inferido de este análisis. A, Región con posibles elementos intensificadores de la expresión. B, Región con elementos reguladores positivos de la expresión. La eliminación de esta secuencia provocó una caída brusca en los niveles de expresión de GUS. C, Región con elementos reguladores negativos de la expresión. Al eliminar esta secuencia se recuperan parcialmente los niveles de expresión de GUS. D, Región con dos posibles elementos reguladores positivos clave en la expresión de END1. Los dos posibles elementos, contenidos en los fragmentos D1 y D2 serían funcionalmente redundantes entre sí. $\mathbf{E}$, Secuencias con un posible elemento represor de la expresión de END1. F, Secuencia con elemento clave para la expresión de END1, posiblemente el motivo CArG2.

Como se ha mencionado anteriormente, en la secuencia 5' de END1 aparecen 2 posibles cajas CArG próximas entre sí (motivo CArG1 y motivo CArG2). La región promotora del gen AP3 de Arabidopsis contiene tres motivos CArG-box entre las secuencias -90 y -180 . Estas secuencias se asemejan a la secuencia consenso en 9 de los 10 nucleótidos que la componen (Okamoto et al., 1994). Se ha demostrado que los homodímeros AP1 y AG y los heterodímoers compuestos por las proteínas AP3 y PI pueden interaccionar in vitro, con diferentes afinidades, con oligonucleótidos sintéticos que contienen las secuencias CArG encontradas en el promotor de AP3 (Riechmann et al., 1996a). La mutación de estas cajas CArG en los dinucleótidos CC o GG alteró el patrón de expresión de GUS en plantas transgénicas que contenían un promotor sintético $A P 3$ fusionado a este gen delator. Además, no mostró afinidad por los fragmentos que contenían las cajas CArG mutadas en ensayos de movilidad electroforética (Tilly et al., 1998). En el segundo intrón del gen AGAMOUS también se encontraron sitios de unión a DNA para los productos de los genes MADS-box. Estas cajas CArG se definieron considerando, igualmente, que sólo uno de los 10 nucleótidos que la componen fuese distinto a los de la secuencia consenso. Con estas premisas se identificaron cuatro posibles cajas CArG (Deyholos y Sieburth, 2000).

El motivo CArG $2\left({ }^{-103}\right.$ CCCAAAATGG $\left.^{-112}\right)$ de la secuencia 5' de END1 cumple las condiciones antes descritas para considerar una secuencia como posible caja CArG: de los 10 nucleótidos que la componen sólo uno es diferente a los que marca la secuencia consenso. La comparación entre el motivo CArG2 y el motivo consenso de unión a DNA reconocido por la proteína AG (Huang et al., 1993) mostró además que las secuencias flanqueantes de ambos motivos tienen gran similitud entre ellas (Figura 39). Se ha demostrado que las secuencias flanqueantes juegan un papel importante en la interacción in vitro entre la proteína AG y el DNA (Shiraishi et al., 1993). A pesar de que el motivo CArG 1 muestra algunas discrepancias con el consenso, también se consideró como posible caja CArG para analizar su función in vivo en un sistema heterólogo. Los motivos CArG1 o CArG2 se eliminaron del contexto de -366 pb de la secuencia 5' de END1 y las secuencias resultantes se fusionaron al gen uidA generándose las construcciones pER18 


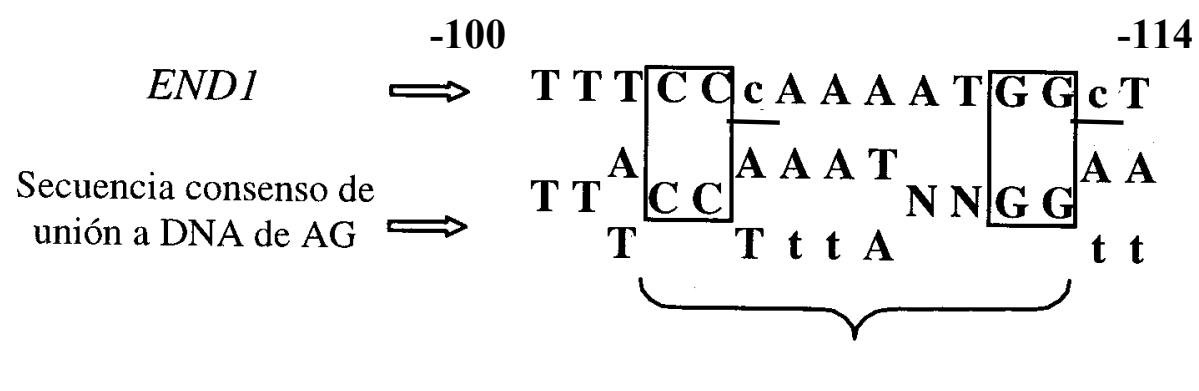

\section{Caja CArG}

Figura 39. Comparación de la secuencia consenso de unión a DNA de AGAMOUS (caja CArG más secuencias flanqueantes) con la secuencia encontrada en la región promotora de END1 (motivo CArG 2 más secuencias flanqueantes). Los nucleótidos de la secuencia de END1 que difieren con la secuencia consenso están indicados en minúsculas subrayadas (Gómez, 2000).

y pER19, respectivamente (Figura 38). Se examinó la distribución de los patrones de expresión de GUS en plantas transgénicas de la generación T1.

La eliminación de la secuencia entre -225 y -208 (construcción pER18), donde se encuentra el motivo CArG1, provocó un aumento en los niveles de expresión de GUS. Todas las plantas transgénicas que contenían esta construcción mostraron un nivel de actividad GUS fuerte o moderado. Sin la deleción interna (-366/-6; construcción pER13) muestraron niveles de expresión de GUS más bajos: aproximadamente sólo el $25 \%$ de las plantas analizadas mostró actividad GUS fuerte y moderado en sus anteras (Figura 38). Por tanto, la secuencia eliminada de la construcción pER18, donde se encuentra una posible caja CArG, podría contener un elemento que actuara reprimiendo la expresión de END1. Una explicación alternativa para este resultado podría ser que la eliminación del fragmento 225/-208 acerque dos elementos reguladores cercanos y que esto tenga un efecto positivo sobre la expresión de GUS dirigida por el fragmento de promotor -366/-6.

Cuando se transformaron plantas con la construcción pER19, en la que se eliminaron del contexto de -366 los nucleótidos comprendidos entre -115 y -99 , donde se encuentra el motivo CArG2, no se observó actividad GUS en ninguna de las plantas transgénicas analizadas. Este es un resultado de interés puesto que indica que es muy posible que el motivo CArG2 juegue un papel clave en la regulación de la expresión de END1.

La presencia de posibles cajas CArG en la secuencia 5' de END1 así como su expresión específica en estambres, sugieren que los genes de identidad de órgano de clase $B$ y $C$ de guisante podrían ser reguladores directos de la expresión del gen END1. La pérdida de la expresión de GUS en las anteras de las plantas que contenían la construcción donde se eliminó el motivo CArG 2, apoyan aún más esta hipótesis.

La identificación de genes homeóticos de clase B y C en guisante y en otras especies sugiere que muchos aspectos del desarrollo floral, incluyendo los genes de identidad de 
órgano floral y posiblemente también las interacciones de los mismos, están conservados respecto a otras especies (Ferrándiz, 1996; Navarro, 2001; Berbel, 2002). El gen PEAM1 es un gen MADS de guisante que presenta un alto nivel de homología de secuencia con genes de identidad de órgano de clase B como PISTILLATA (PI) y GLOBOSA (GLO) de Arabidopsis y Antirrhinum, respectivamente. Su expresión comienza en estadios iniciales del desarrollo floral en el grupo de células que van a originar los primordios comunes, a partir de los cuales se inician los pétalos y los estambres, y se mantiene hasta que estos órganos completan su desarrollo (Navarro, 2001). Este patrón de expresión es similar al descrito para genes de clase $\mathrm{B}$ de otras especies. (Figura $40 \mathrm{~A}$ ). Los genes PEAM7 y PEAM8 son también dos genes MADS de guisante cuyos patrones de expresión en los verticilos internos de la flor (estambres y carpelo) coincide con el descrito para genes de función C (Navarro, 2001) (Figura 40 B). La expresión espacial de END1 coincide con la región en que solapan los dominios de expresión de los genes de clase B y C (los estambres). Sin embargo, la expresión de END1 es algo tardía en comparación con la de los genes homeóticos antes mencionados (Figura $40 \mathrm{C}$ ). Esta diferencia en la expresión temporal de estos genes homeóticos y END1 no significa que este último no pueda hallarse regulado directamente por estos factores de transcripción. La actividad de los genes homeóticos florales se requiere a lo largo del programa de desarrollo de la flor (Bowmann et al., 1989; Zachgo et al., 1995). Así por ejemplo, el gen NAP de Arabidopsis, que es una diana directa del heterodímero AP3/PI, se expresa relativamente tarde en el desarrollo de los pétalos y los estambres (Sablowski y Meyerowitz, 1998).

Hay diversos tipos de experimentos que podrían abordarse para testar si el gen END1 es una diana de genes de clase $\mathrm{B}$ y $\mathrm{C}$ de guisante. Para analizar si la presencia del motivo CArG 2 es, en efecto, imprescindible para la expresión de END1, podríamos analizar con más detalle su funcionalidad in vivo. Para ello podríamos generar construcciones con mutaciones puntuales de este motivo (por ejemplo en los dinucleótidos CC ○ GG) en el contexto del promotor de $-366 /-6$ y fusionarlas al gen uid $A$. Tras transformar plantas de $A$. thaliana con estas construcciones se comprobaría si estas mutaciones puntuales en el motivo CArG 2 provocan la pérdida de la expresión de GUS en las anteras de las plantas transformadas. 


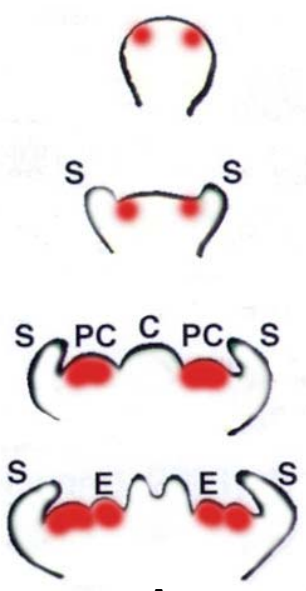

A
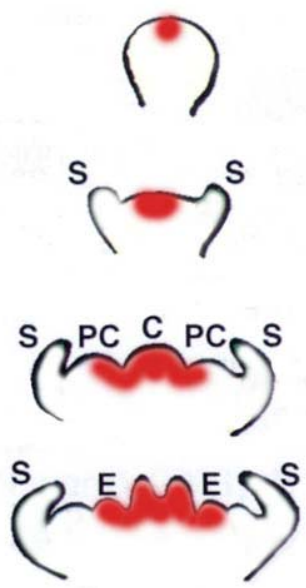

B<smiles>c1ccccc1</smiles><smiles>[S]CCCCCCCS</smiles>

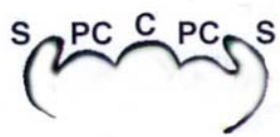

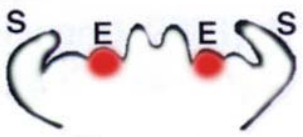

C

Figura 40. Representación esquemática de la expresión temporal y espacial de los genes de identidad de órgano de clase $\mathrm{B}$ (PEAM1) y $\mathrm{C}$ (PEAM7) de guisante y la del gen END1 durante el desarrollo floral. A. Expresión de PEAM1 durante del desarrollo floral. PEAM1 comienza a expresarse en la región media del meristemo floral que dará lugar a los primordios comunes (PC), luego se detecta en el área comprendida entre los primordios de sépalo (S) y carpelo (C), y posteriormente en los primordios comunes. Una vez se han diferenciado éstos, se observa la expresión de PEAM1 uniforme en los primordios de pétalos $(P)$ y estambres (E). B. PEAM7 comienza a expresarse en la zona central del meristemo floral previo al inicio de la diferenciación de los primordios de sépalos. Una vez se han diferenciado éstos, se sigue manteniendo su expresión en la zona central del meristemo. Cuando se han diferenciado los primordios comunes se observa la expresión de PEAM7 en el primordio de carpelo y en la parte interna de los primordios comunes. Posteriormente, su expresión se observa en los primordios del tercer y cuarto verticilo floral. C. END1 comienza a expresarse en los estambres una vez se han diferenciado los primordios comunes en primordios de pétalos y de estambres.

Por otra parte, se podrían realizar ensayos de cambios en la movilidad electroforética (EMSA) (Riechamnn y Meyerowitz, 1997 a; Davies et al., 1996 a) donde se compruebe la unión in vitro de proteínas MADS de clase $\mathrm{B}$ y $\mathrm{C}$ al motivo CArG 2 presente en la región promotora de END1.

Otro tipo de experimento que podría llevarse a cabo para testar la hipótesis de END1 como gen diana de los genes MADS de clase $\mathrm{B}$ y $\mathrm{C}$, consistiría en analizar si en plantas que expresen ectópicamente los genes MADS en cuestión se da también una expresión ectópica de construcciones END1::GUS en los tejidos donde se expresan los genes homeóticos. Por ejemplo, la expresión constitutiva del gen PEAM7 de guisante en plantas de $A$. thaliana, ocasiona transformaciones carpeloides en los órganos del tercer verticilo y estaminoides en los órganos del segundo verticilo (Navarro, 2001). Estas plantas podrían cruzarse con transgénicas transformadas con construcciones END1::GUS (tal como pER14) y analizar si en las plantas con ambas construcciones se observa expresión de GUS en los órganos estaminoides del segundo verticilo.

Por último, podríamos aplicar la estrategia desarrollada por Sablowski y Meyerowitz, (1998), para identificar genes regulados por el heterodímero AP3/PI. Se trata de una 
estrategia compleja que consiste en analizar la inducción de la transcripción del gen de interés en plantas mutantes ap3 que expresen constitutivamente una proteína de fusión entre el polipéptido AP3 y el receptor de glucocorticoide de rata (GR). En condiciones normales, la proteína AP3-GR es incapaz de activar la transcripción, que se halla retenida en el citoplasma, pero se vuelve activa por la aplicación de dexametasona, que permite la entrada al núcleo. En esas condiciones se analiza si el gen de interés se induce inmediatamente tras la activación de la actividad AP3. Para el caso de END1 ya hemos realizado los cruces encaminados a introducir el transgén END1::GUS en ese sistema y así poder analizar la inducción del mRNA de GUS por AP3. 
CONCLUSIONES 

Los resultados que se presentan en esta tesis nos han permitido alcanzar las siguientes conclusiones:

PRIMERA. El promotor del gen END1 de guisante dirige de manera específica la expresión del gen citotóxico barnasa a las anteras de las plantas Arabidopsis thaliana, Nicotiana tabacum y Lycopersicon esculentum. Las plantas transgénicas resultantes son androestériles. Por tanto, este promotor podría ser una herramienta biotecnológica útil en los programas de obtención de semillas híbridas de diferentes cultivos de interés agronómico.

SEGUNDA. El efecto de la expresión del gen citotóxico en las anteras transgénicas de Arabidopsis y tomate se observa desde los primeros estadios de desarrollo. Nuestros resultados sugieren que la expresión del gen barnasa en las células parietales primarias afecta a la diferenciación de las células esporógenas y con ello a la formación de granos de polen viable.

TERCERA. La restauración parcial de la fertilidad en plantas END1::barnasa sugiere que debe ser posible revertir el efecto de la barnasa utilizando el inhibidor barstar.

CUARTA. Todas las plantas androestériles de tomate de la variedad Micro-Tom resultantes de la expresión del transgén END1::barnasa desarrollaron frutos partenocárpicos. Este resultado sugiere que, en tomate, las malformaciones en los estambres que impiden que tenga lugar la polinización provocan partenocarpia. Se sugiere que los estambres podrían actuar como factores reguladores negativos en el proceso de desarrollo del ovario a fruto en esta especie.

QUINTA. La expresión del transgén END1::barnasa en plantas de tomate podría utilizarse como herramienta biotecnológica para la obtención de frutos partenocárpicos de tomate.

SEXTA. Los resultados del análisis funcional del promotor de END1 revelan que el fragmento -366/-6 de la región 5 ' es la secuencia mínima con capacidad para dirigir la correcta expresión espacial y temporal del gen END1.

SÉPTIMA. La pérdida de la expresión de GUS en las anteras de las plantas de Arabidopsis thaliana transformadas con el fragmento de la región 5' donde se elimina el motivo CArG2, apoya la hipótesis de que END1 podría estar regulado directamente por los genes de identidad de órgano de clase $\mathrm{B}$ y $\mathrm{C}$. 

BIBLIOGRAFÍA 

Aarts, M. G. M., Dirkse, W. G., Stiekema, W. J., Pereira, A. (1993). Transposon tagging of a male-sterility gene in Arabidopsis. Nature. 363, 715-717

Ampomah-Dwamena, C., Morris, B. A., Sutherland, P. Veit, B. Y; Yao, J-L. (2002). Down-Regulation of TM29, a tomato SEPALLATA homolog, causes parthenocarpic fruit development and floral reversion. Plant Physiol. 130, 605-617.

Angenent, G. C., Busscher, M., Franken, J., Mol, J. N. M., van Tunen, A. J. (1992). Different expression of two MADS box genes in wild-type and mutant petunia flowers. Plant Cell. 4, 983-993.

Angenent, G. C., Franken, J., Busscher, M., Colombo, L., van Tunen, A J. (1993). Petal and stamen formation in petunia is regulated by the homeotic gene fbp1. Plant J. 4, 101112.

Ariizumi, T., Amagai, M., Shibata, D., Hatakeyama, K., Watanable, M., Toriyama, K. (2002). Comparative study of promoter activity of three anther-specific genes encoding lipid transfer protein, xyloglucan endotransglucosylase/hydrolase and polygalacturonase in transgenic Arabidopsis thaliana. Plant Cell Rep. 21, 90-96.

Ariizumi, T., Hatakeyama, K., Hinata, K., Inatsugi, R., Nishida, I., Sato, S., Kato, T, Tabada, S., Toriyama, K. (2004). Disruption of the novel plant protein NEF1 affects lipid acumulation in the plastids of the tapetum and exine formation of pollen, resulting in male sterile in Arabidopsis thaliana. Plant J. 39. 170-181.

Asahira, T., Takeda, Y., Nishio, T., Hirabayashi, M., Tsuikamoto, Y. (1967). Studies on fruit development on tomato. I. Ovule development and content of diffusible auxin in synthetic auxin and gibberellin-induced parthenocarpic tomato fruits in relation to their development. Mem. Res. Inst. Food Sci. Kyoto Univ. 28, 47-74.

Bhatt, A. M., Canales, C., Dickinson, H. G. (2001). Plant Meiosis: the means to $1 \mathrm{~N}$. Trends Plant Sci. 6, 114-121,

Beals, T. P., Goldberg, R. B. (1997). A novel cell ablation strategy blocks tobacco anther dehiscence. Plant Cell. 9, 1527-1545.

Bechtold, N., Ellis, J., Pelletier, G. (1993). In planta Agrobacterium-mediated gene transfer by infiltration of adult Arabidopsis thaliana plants. C. R. Acad. Sci. Paris, Life Sci. 316, 11941199.

Beltrán, J. P., Ferrándiz, C., Gómez, M. D., Rodríguez-Concepción, M., Pérez, A., Navarro, C., Cañas, L. A. (1996). The use of homeotic mutants to study flower development in Pisum sativum (L.). Flowering Newsl. 22, 41-48.

Berbel, A. (2002). Análisis funcional de genes reguladores del desarrollo floral de guisante (Pisum sativum (L.) en sistemas heterólogos. Tesis Doctoral. Universidad de Valencia.

Berbel, A., Navarro, C., Cañas, L. A., Madueño, F., Beltrán, J. P. (2001). Analysis of $P E A M 4$, the pea $A P 1$ functional homologue, supports a model for $A P 1$-like genes controlling both floral meristem and floral organ identity in different plants species. Plant J. 25, 441-452.

Bowman, J. L., Alvarez, J., Weigel, D., Meyerowitz, E. M., Smyth, D. R. (1993). Control of flower development in Arabidopsis thaliana by APETALA 1 and interacting genes. Development. 119, 721-743. 
Bowman, J. L., Smyth, D. R., Meyerowitz, E. M. (1991). Genetic interactions among floral homeotic genes in Arabidopsis. Development.112, 1-20.

Bowman, J. L., Smyth, D. R., Meyerowitz, E. M. (1989). Genes directing flower development in Arabidopsis. Plant Cell.1, 37-52.

Bradley, D. J., Carpenter, R. R., Sommer, H., Hartley, N., Coen, E. (1993). Complementary phenotypes result from opposite orientations of a transposon al the plena locus of Antirrhinum. Cell.72, 85-95.

Brukhin, V., Hernould, M., Gonzáles, N., Chevalier, C., Mouras, A. (2003). Flower development schedule in tomato Lycopersicon esculentum cv. sweet cherry. Sex Plant Reprod. 15, 311-320.

Brunner, A. M., Rottmann, W. H., Sheppard, L. A., Krutovskii, K., Difazio, S. P., Leonardi, S., Strauss, S. H. (2000). Structure and expression of duplicate AGAMOUS orthologues in polar. Plant Mol. Biol. 44, 619-634.

Cañas, L., Essid, R., Gómez, M D., Beltrán, J. P. (2002). Monoclonal antibodies as developmental markers to characterize pea floral homeotic transformations. Sex Plant Reprod. 15, 141-152.

Carmi, N., Salts, Y., Dedicova, B., Shabtai, S., Barg, Rivka. (2003). Induction of parthenocarpy in tomato via expression of the rolB gene in ovario. Planta. 217, 726-735.

Carniel, K. (1963). Das Antherentapetum. Ein Kristischer Uberblick. Oesterreichische Botanische Zeitscrift, 110, 145-176.

Carpenter, J. L., Ploense, S. E., Snustad, D. P., Silflow, C. D. (1992). Preferential expression of an $\alpha$-tubulin gene of Arabidopsis in pollen. Plant Cell. 4, 557-571.

Catalá, M. S., Costa, J., Nuez, F. (1990). Tomato fruit set under low temperaturas. Acta Hort. 287, 171-180.

Cheung A. Y., Wu, H-m. (2001). Pollen Tube Guidance- Right on Target. Science. 293, 1441-1442.

Christensen, A. H., Quail, P. H. (1996). Ubiquitin promoter-based vectors for high-level expression of selectable and/or screenable marker genes in monocotyledonous plants. Transgenic Research. 5, 213-218.

Clough, S. J., Bent, A. F. (1998). Floral dip: a simplified method for Agrobacterium mediated transformation of Arabidopsis thaliana. Plant J. 16, 735-743.

Coen, E. S. (1991) The role of homeotic genes in flower development and evolution. Ann Rev. Plant Physiol. Plant Mol. Biol. 42, 241-279.

Coen, E. S., Carpenter, R. (1993). The metamorphosis of flowers. Plant Cell. 5, 1175-1181.

Coen, E. S., Meyerowitz, E. M. (1991). The war of the whorls: Genetic interactions controlling flower development. Nature. 353, 31-37.

Collier, R. J. (1975). Diphteria toxin : mode of action and structure. Bacteriol. Rev. 39, 5486. 
Davies, B., Egea-Cortines, M., de Andrade Silva, E., Saedler, H., Sommer, H. (1996). Multiple interactions amongst floral homeotic MADS box proteins. EMBO J. 15, 4330-4343.

Davies, B., Schwarz-Sommer, Z. (1994). Control of floral organ indentity by homeotic MADS-box transcription factors. Results and problems in cell differentiation. Plant Promoters Transcription Factors, 20, 235-258.

Davies, B., Motte, P., Keck, E., Saedler, H., Sommer, H., Schwarz-Sommer, Z. (1999a). PLENA y FARINELLI: redundancy and regulatory interactions between two Antirrhinum MADS-box factor controlling flower development. EMBO J. 18, 4023-4034.

Davies, B., Sommer, H., Schwarz-Sommer, Z. (1999b). Flower development genetics views and molecular views. En: Development: Genetics and Environmental Regulation. Eds. Russo et al. Springer Verlag. Berlín, 167-183.

Day, C. D., Bernard, F. C., Irish, G., Irish, V. (1995). Genetic ablation of petal and stamen primordial to elucidate cell interactions during floral development. Development. 121, 28872895.

Day, C. D., Irish, V. F. (1997). Cell ablation and the analysis of plant development. Trends Plant Sci. 2, 106-111.

De Block, Debrouwer, D., Moens, T. (1997). The development of a nuclear male sterility system in wheat. Expression of a barnase gene under the control of tapetum specific promoters. Theor Appl Genet. 95, 125-131.

Denis, M., Delourme, R., Gourret, J. P., Mariani, C., Renard, M. (1993). Expression of engineered nuclear male-sterility in Brassica-napus genetics, morphology, cytology, and sensitivity to temperature. Plant Phisiol. 101, 1295-1304.

Deyholos, M. K; Sieburth, L. E. (2000). Separable whorl-specific expression and negative regulation by enhancer elements whitin the AGAMOUS second intron. Plant Cell. 12, 17991810.

Dietrich, R. A., Radke, S. E., Harada, J. I. (1992). Downstream DNA sequences are required to activate a gene expressed in the root cortex of embryos and seedlings. Plant Cell. 4, 1371-1382.

Ellul, P., García-Sogo, B., Pineda, B., Ríos, G., Roig, L. A., Moreno, V. (2003). The ploidy level of transgenic plants in Agrobacterium-mediated transformation of tomato cotyledons (Lycopersicon esculentum L. Mill.) is genotype and procedure dependent. Theor. Appl. Genet. 106, 231-238.

Fabijanski, S. F., Arinson, P. G. (1995). Binary cryptocytotoxic method of hybrid seed production. Patent no. US5426041.

Ferrándiz, C. (1996). Morfogénesis floral de mutantes homeóticos de Pisum sativum L. Aislamiento y caracterización molecular de genes de la familia MADS. Tesis Doctoral. Universidad de Valencia.

Ferrándiz, C., Navarro, C., Gómez, M. D., Cañas, L. A., Beltrán, J. P. (1999). Flower development in Pisum sativum: from the war or the whorls to the battle of the common primordia. Dev.Genetic. 25, 280-290. 
Ficcadenti, N., Sestili, S., Pandolfini, T., Cirillo, Ch., Rotino, G. L., Spena, A. (1999). Genetic engineering of parthenocarpic fruit development in tomato. Mol. Breeding. 5, 463470.

Fisher, D. K., Guiltinan, J. (1995). Rapid, efficient production of homocygous transgenic tobacco plants with Agrobacterium tumefaciens: a seed to seed protocol. Plant Mol. Biol. Rep. 13, 278-289.

Fos, M. (1993). Aspectos moleculares del desarrollo partenocárpico del fruto en tomate. Tesis Doctoral. Universidad Politécnica de Valencia.

Fos, M., Nuez, F., García-Martínez, J. L. (2000). The gene pat-2, which induces natural parthenocarpy, alters the gibberellin content in unpollinated tomato ovaries. Plant Physiol. 122, 471-479.

George, W. L., Scott, J. W., Splittstoesser, W. E. (1984). Parthenocarpy in tomato. Hort. Rev.6, 65-84.

Gillaspary, G., Ben-Davied, H., Gruissem, W. (1993). Fruits: A development perspective. Plant Cell. 5, 1439-1451.

Glover, J., Grelon, M., Craig, S., Chaudhury, A., Dennis, E. (1998). Cloning and characterization of MS5 from Arabidopsis: a gene critical in male meiosis. Plant Journal. 15, 345-356.

Goetz, M., Godt, D. E., Guivarc'h., Kahmann, U., Chriqui, D., Roitsch, T. (2001). Induction of male sterility in plants by engineering of carbohydrate supply. PNAS. 22, 65226527.

Goldberg, R. B., Beals, T. P., Sanders, P. M. (1993). Anther development: Basic principles and Practical Applications. Plant Cell, 5, 1217-1299.

Goldman, M. H. S:; Goldberg, R. B., Mariani, C. (1994). Female sterile tobacco plants are produced by stigma-specific cell ablation. EMBO J. 13, 2769-2984.

Gómez, M. D. (2000). END1, un gen de expresión específica en anteras de Pisum sativum. Tesis Doctoral, Universidad de Valencia.

Gómez, M. D., Cañas, L. A., Beltrán, J. P. (2004). The pea END1 promoter drives antherspecific gene expression in different plant species. Planta. En prensa (publicado online: Molb97rl-PIPS DO00000506.

Gómez, P., Jamilenz, M., Capel, J., Zurita, S., Angosto, T., Lozano, R. (1999). Stamenless, a tomato mutant with homeotic conversions in petal and stamens. Planta. 209, 172-179.

Goodwing, P. B. (1978). Phytohormones and fruit growth. En: Phytphormones and Related Compounds. A Comprehensive Tratise, II. Eds. Letham, D.S., Goodwing, P.B. y Higgins, T. J. V. Holanda, 175-214.

Gorman, S. W., McCormick, S. (1997). Male sterility in tomato. Crit.Rev.Plant.Sci. 16, 3153.

Goto, K., Meyerowitz, E. M. (1994). Functional regulation of the Arabidopsis floral homeotic gene PISTILLATA. Genes Dev. 8, 1548-1560. 
Graba, Y., Aragnol, D., Pradel, J. (1997). Drosophila Hox complex downstream targets and the function of homeotic genes. Bioessays.19, 379-388.

Hamilton, D. A., Schwarz, Y. H., Mascarenhas, J. P. (1998). A monocot pollen-specific promoter contains separable pollen-specific and quantitative elements. Plant Mol.Biol. 38, 663-669.

Hanahan, D. (1983). Studies of transformation of Escherichia coli. J. Mol. 166, 557-560.

Hanson, M. R., Conde, M. F. (1985). Functioning and variation of cytoplasmic genomes: lessons from cytoplasmic-nuclear interactions affecting male fertility in plants. Inter. Rev. Cytol. 94, 213-267.

Hartley, R. W., Barker, E. A. (1972). Amino-acid sequence of extracellular ribonuclease (barnase) of Bacillus amyloliquefaciens. Nature New Biol. 235. 158.

Hartley, R. W., Smeaton, J. R. (1973). On the reaction between the extracellular ribonuclease of Bacillus amyloliquefaciens (Barnase) and its intracellular inhibitor (Barstar). Journal of Biol Chem. 248, 5624-5626.

Hartley, R. W. (1989). Barnase and Barstar: two small proteins to fold and fit together. Trends Biochem. Sci. 14, 450-454.

Hartley, R. W. (1988). Barnase and barstar. Expression of its cloned inhibitor permits expression of a cloned ribonuclease. J. Mol. Biol. 202, 913-915.

Hensel, L. L., Nelson, M. A., Richmond, T. A., Bleecker, A. B.(1994). The fate of inflorescence meristems is controlled by developing fruits in Arabidopsis. Plant Physiol. 106, 863-876.

Hewitt, Y. M. (1966). Sand and water culture methods used in the study of plant nutrition. Farnham Royal, Bucks. Commonwealth Agricultural Bureaux.

Hill, J. A., Day, C. D., Zondlo, S. C., Thackeray, A. G., Irish, V. F. (1998). Discrete spatial and temporal cis-acting elements regulate transcription of the Arabidopsis floral homeotic gene apetala3. Development. 125, 1711-1721.

Ho, L. C.; Hewitt, J. D. (1986). Fruit development. En: The tomato crop. Eds. Atherton, J. G.; Rudich, J., Cambridge. 201-239

Hoekema, A., Hirsch, P. R., Hooykaas, P. J .J., Schilperoort, R. A. (1983). A binary plant vector strategy based on separation of vir and T region of the Agrobacterium tumefaciens tiplasmid. Nature. 303, 179-180.

Hong, H. P., Ross, J. H. E., Gerster, J. L., Rigas, S., Datla, R. S. S., Hatzopoulos, P., Scoles, G., Keller, W., Murphy, D., Robert, R. S. (1997). Promoter sequences from two different Brassica napus tapetal oleosin-like genes direct tapetal expression of $\beta$ glucuronidase in transgenic Brassica plants. Plant Mol. Biol. 34, 549-555.

Honma, T., Goto, K. (2001). Complexes of MADS-box proteins are sufficient to convert leaves into floral organs. Nature. 409, 469-471.

Horsh, R. B., Fraley, R. T., Rogers, S. G., Sanders, P. R., Lloyd, A., Hoffmann, N. (1984). Inheritance of functional foreign genes in plants. Science. 223, 496-498. 
Huang, H., Mizukami, Y., Hu, Y., Ma, H. (1993). Isolation and characterization of the binding sequences for the product of the Arabidopsis floral homeotic genes agamous. Nucleic Acid Res. 21, 4769-4776.

Irish, V. F., Sussex, I. M. (1990). Function of the APETALA-1 gene during Arabidopsis floral development. Plant Cell. 2, 741-753.

Jack, T., Brockman, L. L., Meyerowitz, E. M. (1992). The homeotic gene APETALA3 of Arabidopsis thaliana encodes a MADS box and expressed in petals and stamens. Cell. 68, 683-697.

Jack, T., Fox, G. L., Meyerowitz, E. M. (1994). Arabidopsis homeotic gene APETALA3 extopic expression:Transcriptional and posttranscriptional regulation determine floral organ identity. Cell. 76, 703-716.

Jacobsen, S. E., Olszewski, N. E. (1996). Gibberellins regulate the abundance of RNAs with sequence similarity to proteinase inhibitors, dioxygenases and dehydrogenases. Planta. $198,78-86$.

Jofuku, K. D., den Boer, B. G. W., Van Montagu, M. Y., Okamuru, J. K. (1994). Control of the Arabidopsis flower and seed development by the homeotic gene APETALA 2. Plant Cell. 6, 1211-1225.

Kang, H-G., Jeong, J-S., Lee, S., An, G. (1998). Identification of class B and class C floral organ identity genes from rice. Plant Mol. Biol. 38, 1021-1029.

Kang, H-G., Noh, Y-S., Chung, Y-Y., Costa, M. A., An, K., An, G. (1995). Phenotypic alterations of petal and sepal by ectopic expression of rice MADS box gene in tobacco. Plant Mol. Biol. 29, 1-10.

Kater, M. M., Colombo, L., Franken, J., Busscher, M., Masiero, S., van Lookeren Campagne, M. M., Angenent, G. C. (1998). Multiple AGAMOUS homologs from cucumber and petunia differ in their ability to induce reproductive organ fate. Plant Cell. 10, 171-182.

Kawaguchi, M., Kobayashi, M., Sakurai, A., Syono, K. (1991). The presence of an enzyme that converts indole-3-acetamide into IAA in wild and cultivated rice. Plant Cell Physiol. 32, 143-149.

Keck, E., McSteen, P., Carpenter, R., Coen, E. (2003). Separation of genetics functions controlling organ identity in flowers. EMBO J. 5, 1058-1066.

Kempin, S. A., Mandel, A., Yanofsky, M. F. (1993). Conversión of perianth into reproductive organs by ectopic expresión of tobacco floral homeotic gene NAG1. Plant Physiol. 103, 1041-1046.

Kimble, J. (1981). Alterations in cell lineage following laser ablation of cells in the somatic gonad of Caenorhabditis elegants. Dev. Biol. 87, 286-300.

Koltunow, A. M., Truettner, J., Cox, K. H., Wallroth, M., Goldberg, R. B. (1990). Different temporal and spatial gene expression patterns occur during anther development. Plant Cell. 2, $1201-1224$. 
Koncz, C., Schell, J. (1986). The promoter of TL-DNA gene 5 controls the tissue-specific expression of chimeric genes carried by a novel type of Agrobacterium binary vector. Mol. Gen. Genet. 204, 383-396.

Kramer, E. M., Irish, V. F. (2000). Evolution of the petal and stamen development programs: Evidence from comparative studies of the lower eudicots and basal angiosperms. Int. J. Plant Sci. 16, 29-30.

Kriete, G., Niehaus, K., Perlick, A. M., Pühler, A., Broer, I. (1996). Male sterility in transgenic tobacco plants induced by tapetum-specific deacetylation of the externally applied non-toxic compound N-acetyl-L-phosphinothricin. Plant J. 9, 809-818.

Krizek, B. A., Meyerowitz, E. M. (1996). The Arabidopsis homeotic genes APETALA3 y PISTILLATA are sufficient to provide the B class organ identity function. Development. 122, 11-22.

Larkin, J. C., Oppenheimer, D. G., Pollock, S., Marks, M. D. (1993). Arabidopsis GLABROUS1 gene requires downstream sequences for function. Plant Cell. 5, 1739-1748.

Lee, Y-H, Chumg, K-H., Kim, H-U., Jin, Y-M. (2003). Induction of male sterile cabbage using a tapetum-specific promoter from Brassica campestris L. ssp. pekinensis. Plant Cell Rep. 22, 268-273.

Lifschitz, E., Brodai, L., Hareven, D., Hurwitz, C., Prihadash, A., Pnueli, L., Samach, A., Zamir, D. (1993). Molecular mapping of flower development in tomato. En: Molecular Biology of tomato. Ed. Yoder, J. Technomic. Lancaster PA, USA, 175-184.

Lin, S., George, W. L., Splittstoesser, W. E. (1984). Expression and inheritance of parthenocarpy in "Severianin" tomato. J. Hered. 75, 62-66.

Lin, S., Splittstoesser, W. E., George, W. L. (1983). Factors controlling the expression of parthenocarpy in "Severianín" tomato. Sci. Hort. 19, 45-53.

Lukyanenko, A. N. (1991). Parthenocarpy in tomato. En: Genetic improvement of tomato; Monogrhas on Theoretical and Applied Genetics. 14. Eds. Springer-Verlag, Alemania, 167178.

Ma, H., Yanofsky, M. F., Meyerowitz, E. M. (1991). AGL1-AGL6, an Arabidopsis gene family with similarity to floral homeotic and transcription factors genes. Gene Dev. 5, 484495.

Mandel, M. A., Bowman, J. L., Kempin, S. A., Ma, H., Meyerowitz, E. M., Yanofsky, M. F. (1992). Manipulation of flower structure in transgenic tobacco. Cell. 71, 133-143.

Mandel, M, A., Yanofsky, M. F. (1998). The Arabidopsis AGL9 MADS-box gene is expressed in young flower primordia. Sex Plant Reprod. 11, 22-28.

Maniatis, T., Fritsch, E. F., Sambrook, J. (1982). Molecular cloning: a laboratory manual. Cold Spring Harbor Laboratory Press, Cold Spring Harbor, NY.

Manset, J. D. (1998). Botany: An Introduction to Plant Biology, $2^{\text {nd }}$ edition. Boston: Jones and Bartlell. Figure 9.5b.

Mapelli, S., Torti, G., Badino, M., Soressi, G. P. (1979). Effects of GA3 on flowering and fruit-set in a mutant of tomato. Hort. Sci. 14, 736-737. 
Mariani, C., Beuckeleer, M. D., Truettner, J., Leeman, J., Goldberg, R. B. (1990). Induction of male sterile in plants by a chimaeric ribonuclease gene. Nature. 347, 737-741.

Mariani, C., Gossele, V., De Beuckeleer, M., De Block, M., Goldberg, R. B., De Greef, W., Leemans, J. (1992). A chimeric ribonuclease-inhibitor gene restores fertility to male sterile plants. Nature. 357, 384-387.

Mazzetti, B., Landi, L., Pandolfini, Y., Spena, A. (2004). The defH9-iaaM auxin-synthezing gene increases plant fecundity and fruit production in strawberry and raspaberry. BMC. Biotechnology. 4, 1-10.

Mazzucato, A., Taddei, A. R., Soressi, G. P. (1998). The parthenocarpic fruit (pat) mutant of tomato (Lycopersicon esculentum Mill.) sets seedless fruits and has aberrant anther and ovule development. Development. 125, 107-114.

Mazzucato, A., Testa, G., Biancari, T., Soressi, G. (1999). Effect of acid treatments, environmental conditions and genetic background on the expression of the parthenocarpic fruit mutation in tomato. Protoplasma. 208, 18-25.

Mazzucato, A., Olimpieri, I., Ciampolini, F. (2003). A defective pollen-pistil interaction contributes to hamper seed set in the parthenocarpic fruit tomato mutant. Sex. Plant. Reprod. 16, 157-164.

McCormick, S. (1993). Male gametophyte development. Plant Cell. 5, 1266-1275.

Mena, M., Ambrose, B. A., Meeley, R. B., Briggs, S. P., Yanofsky, M. F., Schmidt, R. J. (1996). Diversification of C-function activity in maize flower development. Science. 274, 1537-1540.

Meyerowitz, E. M., Bowman, J. L., Brockman, L. L., Drews, G. N. Jack, T., Sieburth, L. E., Weigel, D. (1991). A genetic and molecular model for flower development in Arabidopsis thaliana. Development. 1 Supl, 157-167.

Mitzuda, N., Takeyasu, K., Sato, M. H. (2001). Pollen-specific regulation of vacuolar H+PPase expression by multiple cis-acting elementos. Plant Mol. Biol. 46, 185-192.

Nacken, W. K. F., Huijser, P., Beltrán, J. P., Saedler., Sommer, H. (1991). Molecular characterization of two stamen-specific genes, tap1 and fil1, that are expressed in the wild type, but not in the deficiens mutant of Antirrhinum majus. Mol. Gen. Genet. 229, 129-136.

Navarro, C. (2001). Genes reguladores del desarrollo floral en guisante (Pisum sativum L.). Tesis Doctoral. Universidad de Valencia.

Nilsson, O., Olsson, O. (1997). Getting to the root: the role of the Agrobacterium rhizogenes rol genes in the formation of hairy roots. Physiol Plant. 100, 463-473.

Nitsh, J. P. (1970). Hormonal factors in growth and development. En: Food Science and technology. Ed. Hulme, A. C. Academic Press, London., 427-472.

Nuez, F., Costa, J., Cuartero, J. (1986) Genetics of the parthenocarpy for tomato varieties "Sub-Artic Plenty", "75/79" and "Severianín". Z Planzenzüchtg. 96, 200-206. 
Okada, T., Sasaki, Y., Otha, R. (2000). Expresión of Bra $r 1$ gene in transgenic tobacco and Bra 1 promoter activity in pollen of various plant species. Plant Cell Physiol. 41, 757-766.

O’ Keefe, D. P., Tepperman, J. M., Dean, C., Leto, K. J., Erbes, D. L., Odell, J. T. (1994). Plant expression of bacterial cytochrome P450 that catalyzes activation of a sulfonylurea pro-herbicide. Plant Physiol. 105, 473-482.

Okamoto, H., Yano, A., Shiraishi, H., Okada, K., Shimura, Y. (1994). Genetic complementation of a floral homeotic mutation, apetala3, with an Arabidopsis thaliana gene homologous to DEFICIENS of Antirrhinum majus. Plant Mol. Biol. 26, 465-472.

Okamuro, J. K., der Van Boer, B. G. W., Jofukun, K. D. (1993). Regulation of Arabidospsis flower development. Plant Cell. 5. 1183-1193.

Paddon, C. W., Hartley, R.W. (1985). Cloning, sequencing and transcription of an inactivated copy of Bacillus amyloliquefaciens extracellular ribonuclease (barnase) Gene. 10, 231-239.

Paddon, C., Hartley, R. W. (1987). Expression of Bacillus amyloliquefaciens extracellular ribonuclease (barnase) in Escherichia coli following an inactivating mutation. Gene. 53, 1119.

Pandolfini, T., Rotino, G., Camerini, S., Defez, R., Spena, A. (2002). Optimization of transgene action at the post-transcriptional level: high quiality parthenocarpic fruits in industrial tomatoes. BMC. Biotechnology. 2, 1-18.

Paul, W., Hodge, R., Smartt, S., Draper, J., Scott, R. (1992). The isolation and characterization of the tapetum-specific Arabidopsis thaliana A9 gene. Plant Mol. Biol. 19, 611-622.

Pecaut, P., Philouze, J. (1978). A sha-pat line obtained by natural mutation. TGC Reports. 28, 12.

Pelaz, S., Ditta, G. S., Baumann, E., Wisman, E., Yanofsky, M. F. (2000). B and C floral organ identity functions require SEPALLATA MADS-box genes. Nature. 405, 200-203.

Pellegrini, L. S. T., Richmond, T. J. (1995). Structure of serum response factor bound to DNA. Nature. 376, 490-49.

Philouze, J. (1983). Parthenocarpie naturelle chez la tomate. I. Revue bibliographique. Agronomie. 3, 311-320.

Philouze, J., Maisonneuve, B. (1978a). Heredity of the natural ability to set parthenocarpic fruits in the soviet variety Severianin. TGC Reports. 28, 12-13.

Philouze, J., Maisonneuve, B. (1978b). Breeding tomatoes for their ability to set at low temperatures. En: Genotype and environment in glasshouse tomato breeding. Eds. Proc. Eucarpia Tomato Working Group. URSS, 54-64.

Pinyopich, A., Ditta, G., Savidge, B., Liljegren, S. J., Baumann, E., Wisman, E., Yanofsky, M. F. (2003). Assesing the redundancy of MADS-box genes during carpel and ovule development. Nature. 424, 85-88.

Pneuli, L., Hareven, D., Rounsley, D., Yanofsky, M. F. (1994). Isolation of the tomato AGAMOUS gene TAG1 and analysis of its homeotic role in transgenic plants. Plant Cell. 6, 163-173. 
Pnueli, L., Abu-Abeid, M., Zamir, D., Nacken, W., Schwarz-Sommer, Z., Lifschitz, E. (1991). The MADS-box gene family in tomato: temporal expression during floral development, conserved secondary structures and homology with homeotic genes from Antirrhinum and Arabidopsis. Plant J. 1, 255-266.

Rentrop, M., Knapp, B., Winter, H., Schweizer. (1986). Aminoalkylsilane-treated glass slides as support for in situ hybridization of keratin cDNAs to frozen tissue sections under varying fixation and pretreatment conditions. Histochem. J., 18, 271-276.

Reynaerts, A., Van de Wiele, H., De Sutter, G., Janssens, J. (1993). Engineered genes for fertility control and their application in hybrid seed production. Scientia Horticulturae. 55, 125-139.

Riechman, J. L., Meyerowitz, E. M. (1997). MADS domain proteins in plant development. Biol. Chem.378, 1079-1110.

Riechmann, J. L., Krizek, B. A., Meyerowitz, E. M. (1996a). Dimerization specificity of Arabidopsis MADS domain homeotic proteins APETALA 1, APETALA3, PISTILLATA, and AGAMOUS. PNAS. USA. 93, 4793-4798.

Riechmann, J. L., Wang, M., Meyerowitz, E. M. (1996b). DNA binding properties of Arabidopsis MADS domain homeotic proteins APETALA 1, APETALA3, PISTILLATA, and AGAMOUS. Nucleic Acid Res. 24, 3134-3141.

Roberts, M. R., Boyes, E., Scott, R. J. (1995). An investigation of the role of anther tapetum during miscrospore development using genetic cell ablation. Sex. Plant Reprod. 8, 299-307.

Rogers, S. O., Bendich, A. J. (1984). Extaction of DNA from milligram amounts of fresh, herbarium and mummified plant tissues. Plant Mol. Biol. 5, 69-76.

Rotino, G. L., Perri, E., Zottini, M., Sommer, H., Spena, A. (1997). Genetic engineering of parthenocarpic plants. Nature Biotechnol. 15, 1398-1401.

Sablowsky, R. W. M., Meyerowitz, E. M. (1998). A homolog of NO APICAL MERSITEM is an immediate target of the homeotic genes APETALA3/PISTILLATA. Cell. 92, 93-103.

Sakai, H., Krizek, B. A., Jacobsen, S. E., Meyerowitz, E. M. (2000). Regulation of Sup expression identifies multiple regulators involved in Arabidopsis floral meristem development. Plant Cell. 12, 1607-1618.

Salts, Y., Kenigsbuch, D., Wachs, R., Gruissem, W., Barg, R. (1992). DNA sequence of the tomato fruit expressed proline-rich protein gene TPRP-F1 reveals an intron within the 3'untranslated transcript. Plant. Mol. Biol. 18, 407-409.

Salts, Y., Wachs, R., Gruissem, W., Barg, R. (1991). Sequence coding for a novel prolinerich protein preferentially expressed in young tomato fruit. Plant. Mol. Biol. 17, 149-150.

Sambrook, J., Fritsch, E, F., Maniatis, T. (1989). Molecular cloning. A laboratory manual. Cold Spring Harbor Laboratory Press, New York.

Sanders, P. M., Bui, A. Q., Weterings K., Mclntire, K. N., Hsu, Y-C., Lee, P. Y., Truong, M. T., Beals, T., Goldberg, R. B. (1999). Anther developmental defects in Arabidopsis thaliana male-sterile mutants. Sex Plant Reprod. 11, 297-322. 
Sanger, F., Nicklen, S., Coulso, A. R. (1977). DNA sequencing with chain termination inhibitors. PNAS. USA. 74, 5463-5467.

Satina, S., Blakeslee, A. F., Avery, A. G. (1940). Demonstration of three germ layers in the shoot apex of Datura by means of induced polyploidy in periclinal chimeras. Am. J. Bot. 27, 895-905.

Savidge, B., Rounsley, S. D., Yanofsky, M. F. (1995). Temporal relationship between the transcription of two Arabidopsis MADS Box genes and the floral organ identity genes. Plant Cell. 7, 721-733.

Sawhney, V. K., Greyson, R. I. (1973). Morphogenesis of the stamenless-2 mutant in tomato. Comparative description of the flowers and ontogeny of stamens in the normal and mutant plants. Amer. J. Bot. 60, 514-532.

Schiefthaler, V., Balasubramanian, S., Sieber, P., Chevalier, D., Wisman, E., Schneitz, K. (1999). Molecular analysis of NOZZLE, a gene involved in pattern formation and early sporogenesis during sex organ development in Arabidopsis thaliana. PNAS. 96, 1166411669.

Schmidt, R. J., Veit, B., Mandel, M. A., Mena, M., Hake, S., Yanofsky, M. F.(1993). Identification and molecular characterization of $Z A G 1$, the maize homolog of Arabidopsis floral homeotic gene AGAMOUS. Plant Cell. 5, 729-737.

Schmulling, T., Fladung, M., Grossman, K., Schell, J. (1993). Hormonal control and sensitivy of transgenic tobacco and potato plants expressing simgle rol genes of Agrobacterium rhizogenes T-DNA. Plant J. 3, 371-382.

Schmulling, T., Schell, J., Spena, A. (1988). Single genes from Agrobacterium rhizogenes influence plant development. EMBO J. 7, 2621-2629.

Schwabe, W. W., Mills, J. J. (1981). Hormones and parthenocarpic fruit set: a literature survey. Hort. Abstracts. 51, 661-698.

Schwarz-Sommer, Z., Hue, I., Huijser, P., Flor, P. J., Hansen, R., Tetens, F., Lonning, W. E., Saedler, H., Sommer, H. (1992). Characterization of the Antirrhinum floral homeotic MADS-box gene deficiens. Evidence throughout flower development. EMBO J. 11, 251-263.

Schwarz-Sommer, Z., Huijser, P., Nacken, W., Saedler, H., Sommer, H. (1990). Genetic control of flower development by homeotic genes in Antirrhinum majus. Science. 250. 931936.

Scott, R., Dagless, E., Hodge, R., Paul, W., Soufleri, I., Draper, J. (1991a). Patterns of gene expression in developing anthers of Brassica napus. Plant Mol. Biol. 17, 195-207.

Scott, R. J., Hodge, R., Paul, W., Draper, J. (1991b). The molecular biology of anther differentiation. Plant Sci. 80, 167-191.

Scott, R. J., Spielman, M., Dickinson, H. G. (2004). Stamen structure and function. Plant Cell, 16 (suppl), S46-S60.

Shiba, H., Takayama, S., Iwano, M., Shimosato, H., Funato, M., Nakagawa, T., Che, F. S., Suzuki, G., Watanabe, M., Hinata, K., Isogai, A. (2001). A pollen coat protein 
SP11/SCR, determines the pollen S specificity in the self-incompatibility of Brassica species. Plant Physiol. 125, 2095-2103.

Shiraishi, H., Okada, K., Shimura, Y. (1993). Nucleotide sequences recognized by the AGAMOUS MADS domain of Arabidopsis thaliana in vitro. Plant J. 4, 385-398.

Shore, P., Sharrocks, A. D. (1995). The MADS-box family of transcription factors. Eur. J. Biochem. 229, 1-13.

Sieburth, L. E., Meyerowitz, E. M. (1997). Molecular dissection of the AGAMOUS control region shows that cis elements for spatial regulation are located intragenically. Plant Cell. 9, 355-365.

Smeaton, J. R., Elliot, W. H. (1967). Isolation and properties of a specific bacterial ribonuclease inhibitor. Biochem. Biophys. Acta. 145, 547-560.

Smith, A. G., Gasser, C. S., Budelier, K. A., Fraley, R. T. (1990). Identification and characterization of stamen and tapetum specific genes from tomato. Mol. Gen. Genet. 222, 9-16.

Smyth, D. R., Bowman, J. L., Meyerowitz, E. M. (1990). Early flower development in Arabidopsis. Plant Cell., 755-767.

Sommer, H., Beltrán, J. P., Huijser, P., Pape, H., Lönnig, W., Saedler, H., SchwarzSommer, Z. (1990). Deficiens, a homeotic gene involved in the control of flower morphogenesis in Antirrhinum majus: The protein shows homology to transcription factors. EMBO J.9, 605-613.

Sorensen, A-M., Kröber, S., Unte, U. S., Huijser, P., Dekker, K., Saedler, H. (2003). The Arabidopsis ABORTED MICROSPORES (AMS) gene encodes a MYC class transcription factor. Plant J. 33, 413-423.

Soressi, G. P. (1970). Tomato mutants following EMS seed treatments. TGC Reports. 20, 59.

Soressi, G. P., Salami, F. (1975). A monomendelian gene inducing parthenocarpic fruits. TGC Reports. 25, 22.

Spena, A., Estruch, J. J., Prinsen, E., Nacken, W., Van Onckelen, H., Sommer, H. (1992). Anther-specific expression of the rolB gene of Agrobacterium rhizogenes increases IAA content in anthers and alters anther development and whole growth. Theor App/ Genet. 84, 520-527.

Spena, A., Ficcadenti, N., Rotino, G. L., Defez, R. (1999) Method to modulate the expresión of genes inducing the parthenocarpic trait in plants. IPO Patent NIPOW0105985A1.

Sulston, J. E., White, J. G. (1980). Regulation and cell anatomy during postembryonic development of Caenorhabditis elegants. Dev Biol. 78, 577-597.

Tebbut, S. J., Lonsdale, D. M. (1995). Deletion analysis of a tobacco pollen-specific polygalacturonase promoter. Sex.Plant.Reprod. 8, 242-246.

Testa, G., Caccia, R., Tilesi, F. (2002). Sequencing and characterization of tomato genes putatively involved in fruit set and early development. Sex. Plant. Reprod. 14, 269-277. 
Theis, R., Robbelen, G. (1990). Anther and microspore development indifferent male sterile plants of oilseed rape (Brassica napus L). Angew Bot. 64, 419-434.

Theissen, G., Becker, A., Di Rosa, A., Kanno, A., Kim, J. T., Múnster, T., Saedler, H. (2000). A short history of MADS-box genes in plants. Plant Mol. Biol. 42, 115-149.

Theissen, G., Saedler, H. (2001). Floral quartets. Nature. 409, 469-471.

Thorsness, M. K., Nasrallah, J. B. (1995). Cell-specific ablation in plants. Methods in Cell Biology. 50, 439-448.

Tilly, J., Allen, D. W., Jack, T. (1998). The CArG boxes in the promoter of the Arabidopsis floral organ identity gene APETALA 3 mediate diverse regulatory effects. Development. 125, 1647-1657.

Tröbner, W. S., Ramírez, L., Motte, P., Hue, I., Huijser, P., Lonning, W. E., Saedler, H., Sommer, H., Schwarz-Sommer, Z. (1992). GLOBOSA: a homeotic gene which interacts with DEFICIENS in the control of Antirrhinum floral organogenesis. EMBO J. 11, 4693-4704.

Tsaftaris, S. A. (1995). Molecular aspects of heterosis in plants. Physiol. Plantarum. 94, 362-370.

Tsuchiya, T., Toriyama, K., Yoshikawa, M., Ejiri, S-i., Hinata, K. (1995). Tapetum-specific expression of the gene for an Endo- $\beta-1,3$ glucanase causes male sterility in transgenic tobacco. Plant Cell Physiol. 36, 487-494.

Tucker, S. C. (1989). Overlapping organ initiation and common primordia in flowers of Pisum sativum (Leguminosae: Papilionoidae). Am. J. Bot. 76, 714-729.

Twell, D. (1994). The diversity and regulation of gene expression in the pathway of male gametophyte development. En: Molecular and cellular aspects of plant reproduction. Eds. Scott, R.J., Snead, A.D. Society for Experimental Biology. Seminar Series 55: Cambridge University Press, 83-135.

Twell, D. (1995). Diphteria toxin-mediated cell ablation in developing pollen: vegetative cell ablation blocks generative cell migration. Protoplasma. 187, 144-154.

Twell, D. (2002) The developmental biology of polen. En Plant Reproduction. Annual plant reviews, 6. Eds O’Neil, S. D y Robert, J. A. Academic Press. Sheffield, 86-153.

Twell, D., Yamaguchi, J., McCormick, S. (1990). Pollen-specific gene expression in transgenic plants: coordinate regulation of two different tomato gene promoters during microsporogenesis. Gene Dev. 109, 705-713.

Twell, D., Yamaguchi, J., Wing, R. A., Ushiba, J., McCormick, S. (1991) Promoter analysis of genes that are coordinately expressed during pollen development reveals pollenspecific enhancer sequences and shared regulatory elements. Gene Dev. 5, 496-507.

Twell, D., Wing, R., Yamaguchi, J., McCormick, S. (1989). Isolation and expression of an anther-specific gene from tomato. Mol. Gen. Genet. 217, 240-245.

Vandenbussche, M., Zethof, J., Royaert, S., Weterings, K., Gerats, T. (2004). The duplicated B-class heterodimer model: whorl-specific effects and complex genetic interactions in petunia hybrida flower development. Plant Cell. 16, 741-754. 
van der Krol, A .R., Brunelle, A., Tsuchimoto, S., Chua, N. H. (1993). Functional analysis of petunia floral homeotic MADS box gene pMADS1. Genes Dev. 7, 1214-1228.

Varoquaux, F., Blanvillain, R., Delseny, M., Gallois, P. (2000). Less is better : new appraches for seedless fruit production. Trend Biotech. 18, 233-242.

Verdel, F., Pla, M., Vitart, V., Gutierres, S., Chétrit, P., De Paepe, R. (1994). Molecular basis of nuclear and cytoplasmic male sterility in higher plants. Plant Physiol. Bioch. 32, 601-618.

Weigel, D., Meyerowitz, E. M. (1994). The ABCs of floral homeotic genes. Cell, 78, 201209.

Wen-jun, S., Forde, B. G. (1989). Efficient transformation of Agrobacterium spp. by high voltage electroporation. Nucleic Acid Res. 17. 4415.

Weterings, K., Schrauwen, J., Wullems, G., Twell, D. (1995). Functional dissection of the promoter of the pollen-specific gene NTP303 reveals a novel pollen-specific, and conserved cis-regulatory element. Plant J. 8, 55-63.

Wilcock, C., Neiland, R. (2002). Pollination failure in plants: why it happens and when it matters. Trends Plant Sci. 7, 270-277.

Williams, M. E. (1995). Genetic engineering for pollination control. Trends Biotechnol. 13, 344-349.

Wilson, Z. A., Morrol, S. M., Dawsonh, J., Swarup, R., Tighe, P. J. (2001). The Arabidopsis MALE STERILITY (MS1) gene is a transcriptional regulator of male gametogenesis, with homology to the PHD-finger family of transcription factors. Plant J. 28, 27-39.

Worral, D., Hird, L., Hodge, R., Paul, W., Draper, J., Scott, R. (1992). Premature dissolution of the microsporocyte callose wall causes male sterility in transgenic tobacco. Plant Cell. 4, 759-771.

Yamada, T., Palm, C. J., Brooks, B., Kosuge, T. (1985). Nucleotide sequence of the Pseudomoas savastanoi indoleacetic acid genes show homology with Agrobacterium tumefaciens T-DNA. PNAS. USA. 82, 6522-6526.

Yang, S-L., Xie, L-F., Mao, H-Z., Puah, C. S., Yang, W-C., Jiang, L., Sundaresan, V., Ye, D. (2003). TAPETUM DETERMINAT1 is required for cell specialization in the Arabidopsis anther development. Plant Cell. 15, 2792-2804.

Yang, M., Hu, Y., Lodhi, M., McCombie, W. R., Ma, H. (1999a). The Arabidospsis SKP1LIKE gene is essential for male meiosis and may control homologue separation. PNAS. USA. 96, 11416-11421.

Yang, W. C., Ye, D. D, Xu, J., Sundaresan, V. (1999b). The SPOROCYTELESS gene of Arabidopsis is required for initiation of sporogenesis and encodes a novel nuclear protein. Genes and Development. 13, 2108-2117.

Yanofsky, M. F., Ma, H., Bowman, J. L., Drews, G., Feldmann, K., Meyerowitz, E. M. (1990). The protein encoded by the Arabidopsis gene AGAMOUS resembles transcription factors. Nature. 346, 35-39. 
Yao, J-L., Dong, Y-H., Morris, B. A. M. (2001). Parthenocarpic apple fruit production conferred by transposon insertion mutations in a MADS-box transcription factor. PNAS. 30 , 1306-1311.

Yu, D., Kotilainen, M., Pöllänen, E., Mehto, M., Elomaa, P., Helariutta, Y., Albert, V. A., Teeri, H. (1999). Organ identity genes and modified patterns of floral development in Gerbera hybrida (Asteraceae). Plant J. 17, 51-62.

Zachgo, S., Silva, E.A., Motte, P., Tröbner, W., Saedler, H., Schwarz-Sommer, Z. (1995). Functional analysis of the Antirrhinum homeotic DEFICIENS gene in vivo and in vitro using a temperature sensitive mutant. Development. 121, 2861-2875.

Zhan, X-y., Wu, H-m., Cheung, A. Y. (1996). Nuclear male sterility induced by pollenspecific expression of a ribonuclease. Sex. Plant Reprod. 9, 35-43.

Zhao, D-Z., Wang, G-F., Speal, B., Ma, H. (2002). The EXCESS MICROSPOROCITES 1 gene encodes a putative leucine-rich repeat receptor protein kinase taht controls somatic and reproductive cell fates in the Arabidopsis anther. Genes and Development. 16, 20212031.

Zik, M., Irish, V. F. (2003). Global identification of target genes regulated by APETALA3 and PISTILLATA floral homeotic gene action. Plant Cell. 15, 207-222.

Zou, J-T., Zhan, X-Y., Wu, H-M., Wang, H., Cheung, A. Y. (1994). Characterization of a rice pollen-specific gene and its expression. American Journal of Botany. 8, 522-561. 